
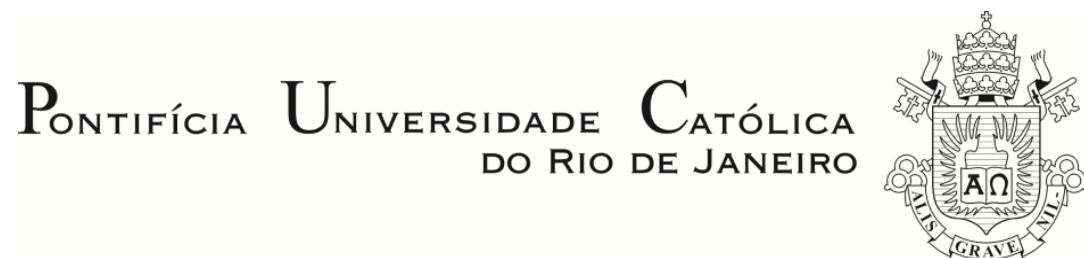

Luiza Xavier Pereira

\title{
O cotidiano da Favela Nova Holanda como reflexão para um projeto plural de cidade
}

\author{
Dissertação de Mestrado
}

Dissertação apresentada ao Programa de PósGraduação em Arquitetura do Departamento de Arquitetura e Urbanismo da PUC-Rio como requisito parcial para obtenção do grau de Mestre em Arquitetura.

Orientador: Prof. Fernando Betim Paes Leme 


\title{
Pontifícia Universidade C $_{\text {atólica }}$ \\ DO RIO DE JANEIRO
}

Luiza Xavier Pereira

\author{
O cotidiano da Favela Nova Holanda \\ como reflexão para um projeto plural de cidade
}

Dissertação apresentada como requisito parcial para obtenção do grau de Mestre ao Programa de Pós-Graduação em Arquitetura do Departamento de Arquitetura e Urbanismo da PUC-Rio. Aprovada pela Comissão Examinadora abaixo assinada.

Prof. Fernando Betim Paes Leme Orientador Departamento de Arquitetura e Urbanismo - PUC-Rio

Prof. Marcos Favero Departamento de Arquitetura e Urbanismo - PUC-Rio

Profa. Maria Laís Pereira da Silva Programa de Pós-Graduação em Arquitetura e Urbanismo - PPGAU da Universidade Federal

Fluminense

Prof. Rafael Soares Gonçalves Programa de Pós-Graduação em Serviço Social SER - PUC-Rio

Profa. Monah Winograd Coordenadora Setorial do Centro de Teologia e Ciências Humanas - Puc-Rio 
Todos os direitos reservados. É proibida a reprodução total ou parcial do trabalho sem autorização do autor, do orientador e da universidade.

\section{Luiza Xavier Pereira}

Graduou-se em Desenho Industrial na PUC-Rio em 2009, nas habilitações de Projeto de Produto e Comunicação Visual.

Ficha Catalográfica

Pereira, Luiza Xavier

O cotidiano da favela Nova Holanda como reflexão para um projeto plural de cidade / Luiza Xavier Pereira ; orientador: Fernando Betim Paes Leme. - 2017.

171 f. : il. color. ; $30 \mathrm{~cm}$

Dissertação (mestrado)-Pontifícia Universidade Católica do Rio de Janeiro, Departamento de Arquitetura e Urbanismo, 2017.

Inclui bibliografia

1. Arquitetura - Teses. 2. Arquitetura e Urbanismo - Teses. 3. Favela Nova Holanda. 4. Direito à cidade. 5. Representação. 6. Cotidiano. 7. Fotografia. I. Leme, Fernando Betim Paes. II. Pontifícia Universidade Católica do Rio de Janeiro. Departamento de Arquitetura e Urbanismo. III. Título. 


\section{Agradecimento}

Essa dissertação, certamente, é resultado da contribuição de muitas pessoas que, de diferentes formas, me ajudaram a trilhar os caminhos, refletir sobre o processo e desenvolver a pesquisa em si.

Primeiramente, agradeço aos fotógrafos Bira Carvalho, Elisângela Leite e Rosilene Miliotti, sem os quais esse trabalho não seria possível. Por terem, com tanta generosidade e confiança, cedido seu tempo e exposto seus olhares. Por terem disponibilizado o uso de suas imagens para esta dissertação e, acima de tudo, por se proporem a construir novas visões sobre a cidade.

À Maria Isabel Couto, amiga-irmã de longa data, a pessoa que desde meus primeiros dias de mestrado me mostrou possibilidades, me apresentou autores, teorias, discussões. Revisou tantos textos e, em tantos momentos, discutiu o processo do projeto.

Ao meu orientador, Fernando Betim, pela confiança que depositou em mim, pelas trocas e disponibilidade, pelas oportunidades que me abre e pelas parcerias que propõe.

Ao professor Rafael Soares Gonçalves, membro da banca, pelo aceite para a participação, mas principalmente, por ter me apresentado possíveis caminhos, que se tornaram tão importantes para esta dissertação.

Ao professor Marcos Favero, também membro da banca, pelas leituras cuidadosas e sugestões atentas feitas desde o início da formulação da pesquisa. Sem dúvida, foram fundamentais para a proposta desenvolvida aqui.

À professora Maria Laís Pereira da Silva, pela contribuição logo no início desta pesquisa e agora, ao final, pelo aceite para ser parte da banca. Pela disponibilidade, carinho e inspiração.

À professora Ana Luiza Nobre, por me incentivar a buscar o campo da arquitetura. Por apresentar tantos autores aqui utilizados e pelas trocas cruciais nesse processo.

Aos tantos outros professores que também contribuíram nesses últimos anos. Não poderia deixar de destacar meu agradecimento à professora Maíra Machado Martins, suplente da banca, pelas bibliografias apresentadas e disponibilidade; ao professor Pablo Benetti, pelas oportunidades que me abriu e os contatos que possibilitou; às trocas com o professor Michel Masson e a professora Sarah Silva Teles, ambos que, com tamanha generosidade, contribuíram em diferentes momentos.

À CAPES e à PUC-Rio, pelos auxílios que tornaram este trabalho possível. 
Aos entrevistados que disponibilizaram seus tempos ao longo da pesquisa. Em especial, ao Lino Teixeira, Francisco Valdean e Thiago Matiolli, não só pelas ricas trocas, mas também pelos contatos para entrevistas.

Aos colegas de mestrado e, em especial à Julia Sá Earp e Valentina Urrejola, parceiras de tantos momentos e discussões ao longo do curso.

Aos tantos amigos que me ajudaram ao longo destes anos de tantas formas. Ao carinho e diferentes revisões de Marcela Antunes, Alessandra Evangelho, Esther Padilha, Maria Isabel Oschery e Fabrício Astua.

Aos meus pais, Helia Nacif e Orcirio Freire, que nos gestos mais singelos e cotidianos, tanto me ensinam sobre a poesia da vida. Pela inspiração que me dão a cada dia, por me apoiarem em meus novos rumos, por terem sido tão compreensivos em minhas ultimas ausências e pelo carinho de sempre. Ao meu irmão, Fernando Xavier, pela parceria e trocas de tantos anos.

Por fim, ao meu companheiro, Fernando Teixeira, pela revisão e discussão de cada linha dessa pesquisa, pelos carinhos e provocações, por ter compartilhado as doçuras e amarguras desses anos e dessa etapa de vida acadêmica. Por ser meu grande parceiro. 


\section{Resumo}

Pereira, Luiza Xavier; Leme, Fernando Betim Paes. O cotidiano da Favela Nova Holanda como reflexão para um projeto plural de cidade. Rio de Janeiro, 2017. 171p. Dissertação de Mestrado - Departamento de Arquitetura e Urbanismo, Pontifícia Universidade Católica do Rio de Janeiro.

A pesquisa tem o objetivo de apresentar diferentes representações sobre o espaço comum do Rio de Janeiro, discutindo, assim, a importância de uma visão plural sobre a cidade. Para apontar tal questão, parte-se de representações da Favela Nova Holanda, no Complexo da Maré, construídas pelo olhar de três moradores através de fotografias sobre o cotidiano local. Ao intercalar o conteúdo de tais imagens, de entrevistas com os fotógrafos e do pensamento teórico de autores como Henri Lefebvre, entre outros, propõe-se discutir formas de se "fazer"/pensar o espaço urbano carioca distintas da proposta pela lógica hegemônica, responsável pela construção do Rio de Janeiro como palco de megaeventos, no período entre 2009 e 2016. A lógica de construção da cidade como mercadoria (própria do período em questão) contribuiu para a segregação e controle dos espaços que não se inseriam na concepção do que era desejado para a imagem da "Cidade Maravilhosa". Ao contrário da homogeneidade que se pretende impor, a diversidade é inerente ao espaço urbano. A partir de tal cenário, o projeto procura debater a importância das intervenções e vivências cotidianas existentes na escala das ruas para a construção de outras visões/projetos de cidade, mais inclusivos e plurais. Partindo do entendimento de que representações construídas sobre o espaço teriam tanta importância em sua produção quanto as relações sociais em si, pretende-se expor dinâmicas do espaço e os olhares distintos sobre o cotidiano vivido na cidade a partir da visão de quem o habita.

\section{Palavras-chave} fotografia.

Favela Nova Holanda; Direito à cidade; representação; cotidiano; 


\section{Abstract}

Pereira, Luiza Xavier; Leme, Fernando Betim Paes. The daily life of favela Nova Holanda as a reflection for a plural project for Rio de Janeiro. Rio de Janeiro, 2017. 171p. Dissertação de Mestrado - Departamento de Arquitetura e Urbanismo, Pontifícia Universidade Católica do Rio de Janeiro.

The research aims to present different representations around the commom space of Rio de Janeiro, thus discussing the importance of plural points of view on the city. To highlight this issue, representations of Favela Nova Holanda, a part of the Maré Favelas Complex, will be used. These representations were made by three local residents through photographs of local daily life. By crossing the content of these images, with interviews with photographers and the theoretical framework of authors such as Henri Lefebvre, among others, the research proposes a discussion around ways of "making" and thinking the urban space. This approach differs from the one proposed by an hegemonic logic and responsible for the construction of Rio de Janeiro as a mega-events stage, in the period between 2009 and 2016. Such logic contributed to the segregation and the control of spaces not inserted in the desired conception of the image of Rio de Janeiro as the "Marvelous City". Contrary to the homogeneity this logic attempts to impose, diversity is an inherent characteristic of the urban space. Starting from this scenario, the project intends to discuss the importance of daily interventions and experiences within the street scale for the construction of more inclusive and plural city visions / projects. Beginning from the understanding that representations built on space may have as much importance in its production as social relations themselves, the research intends to expose the dynamics of space and the different views of the daily life lived in the city from the vision of those who live in it.

\section{Keywords}

Favela Nova Holanda; Right to the city; Representation; daily life; photography. 


\section{Sumário}

1. Introdução 12

2. Entendendo o contexto:

uma revisão teórica sobre a produção do espaço 18

2.1. Cidade: uma invenção do ser humano 19

2.2. A cidade como máquina $\quad 22$

2.3. A cidade como mercadoria $\quad 30$

2.4. A cidade como palco de disputa 35

$\begin{array}{ll}\text { 2.4.1. A produção do espaço } & 37\end{array}$

3. O Rio de Janeiro concebido:

a Cidade Maravilhosa como imagem-marca 43

3.1. O discurso construído: de "cidade em crise" a Cidade Olímpica 45

3.2. As representações do espaço concebidas para a capital 51

carioca

3.2.1. A cidade desenhada nos cases publicitários 53

3.2.2. A cidade chancelada como Patrimônio da Humanidade 64

3.2.3. A cidade construída para o espetáculo urbano 70

4. O Rio de Janeiro vivido:

olhares sobre a cidade a partir da Favela Nova Holanda 87

4.1. O Complexo da Maré $\quad 88$

4.1.1. A Favela Nova Holanda 9

4.2. Três olhares sobre a Nova Holanda 99

4.2.1. O processo da pesquisa 101

4.2.2. Sobre os fotógrafos 103

4.3. As representações construídas sobre o cotidiano local 107

4.3.1. Espaço próprio 107

4.3.2. Espaço compartilhado 123

4.3.3. Espaço dinâmico 132

4.3.4. Espaço de fé e resistência 146

5. Considerações Finais 157

6. Referências bibliográficas 163 


\section{Lista de figuras}

Figura 1 - Imagens iniciais do vídeo apresentado ao COI, em 2009.

Frames selecionados pela autora. Fonte:

https://www.youtube.com/watch?v=nTK90nJbtwQ

Figura 2 - Frame do vídeo apresentado ao COI com simulação do

Parque Olímpico da Barra da Tijuca. Fonte:

https://www.youtube.com/watch?v=nTK90nJbtwQ

Figura 3 - Imagens de vídeo produzido na ocasião da candidatura da cidade para sediar os Jogos Olímpicos, em 2009. Frames selecionados pela autora. Fonte: https://www.youtube.com/watch?v=_AW_isJfiVA.......58

Figura 4 - fonte: Fonte: https://www.youtube.com/watch?v=_AW_isJ fiVA.......

Figura 5 - Logotipo e conceito usados na campanha desenvolvida para o Governo do Estado, 2011.

Figura 6 - Os seis "valores" do Rio de Janeiro, segundo a campanha.

Frames do vídeo da Prole sobre o projeto, selecionados pela autora.

Fonte: http://www.prole.com.br/cases/?Ing=pt\#1

Figura 7 - Elaboração: CDURP/ Instituto Pereira Passos (2015).

Fonte: Observatório de Metrópoles

Figura 8 - Representação visual do porto. Fonte: site da Prefeitura

Figura 9 - Representação visual da Orla Conde, na frente marítima, também parte da Operação Urbana. Fonte:

http://www.portomaravilha.com.br/noticiasdetalhe/4285.

Figura 10 - Representação visual do projeto do Museu do Amanhã.

Fonte: https://arcoweb.com.br/finestra/arquitetura/santiago-calatrava-

museu-amanha-rio-janeiro-2014

Figura 11 - Representação visual do Aqwa Corporate, assinado pelo escritórioFoster+Partners. Fonte: http://tishmanspeyer.com.br /comercial/aqwacorporate

Figura 12 - Representação visual do empreendimento Trump Towers.Fonte:http://www.portomaravilha.com.br/noticiasdetalhe/4058....78

Figura 13 - imagens do vídeo do empreendimento Aqwa Corporate. Fonte: https://vimeo.com/204243007

Figura 14 - Imagem da Linha Vermelha. Fonte: Google Street View. .90 
Figura 15 - Vista aérea do Complexo da Maré na década de 1970/1980. Fonte: Museu da Maré.

Figura 16 - A Favela Nova Holanda na década de 1970.

Fonte: Museu da Maré. 96

Figura 17 - Fotógrafo: Bira Carvalho................................................110

Figura 18 - Fotógrafa: Rosilene Miliotti..............................................112

Figura 19 - Fotógrafa: Elisângela Leite ............................................114

Figura 20 - Fotógrafa: Elisângela Leite...............................................116

Figura 21 - Fotógrafo: Bira Carvalho................................................117

Figura 22 - Fotógrafa: Rosilene Miliotti............................................119

Figura 23 - Fotógrafa: Elisângela Leite..............................................122

Figura 24 - Fotógrafa: Rosilene Miliotti.............................................128

Figura 25 - Fotógrafa: Rosilene Miliotti.............................................130

Figura 26 - Fotógrafo: Bira Carvalho ..................................................134

Figura 27 - Fotógrafa: Rosilene Miliotti.............................................137

Figura 28 - Fotógrafa: Elisângela Leite...............................................139

Figura 29 - Fotógrafa: Rosilene Miliotti.............................................140

Figura 30 - Fotógrafo: Bira Carvalho .................................................142

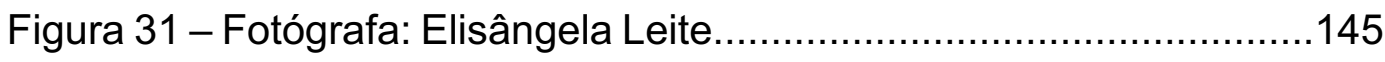

Figura 32 - Fotógrafo: Bira Carvalho.................................................146

Figura 33 - Fotógrafo: Bira Carvalho................................................149

Figura 34 - Fotógrafa: Rosilene Miliotti.............................................152

Figura 35 - Fotógrafa: Elisângela Leite..............................................154

Figura 36 - Fotógrafo: Bira Carvalho.................................................156 
De uma cidade, não aproveitamos as suas sete ou setenta e sete maravilhas, mas a resposta que dá às nossas perguntas.

Italo Calvino, As cidades invisiveis 


\section{Introdução}

A pesquisa aqui apresentada tem como objetivo principal a discussão sobre um projeto plural para o Rio de Janeiro a partir da inclusão das favelas na agenda da cidade como lugares de potencialidades. Propõe-se refletir sobre possíveis alternativas para se pensar o espaço urbano carioca a partir de representações construídas sobre a cidade. Neste contexto, trato por um lado da imagem-marca "oficial" que se pretendeu construir no período de 2009-2016 e, por outro lado, de representações construídas por moradores de um espaço específico da cidade, a Favela Nova Holanda. Busco nas representações do espaço comum da cidade compreender o que as mesmas poderiam revelar sobre formas de construir e pensar o Rio de Janeiro.

A imagem "oficial" que se buscou desenvolver para a cidade no período em questão foi pautada conforme interesses e a visão de mundo de grupos específicos. O projeto proposto para o Rio de Janeiro naquele momento pretendia definir a capital fluminense como uma cidade turística global, a qual seria ideal para sediar megaeventos. Para tanto, o que se viu foi a exclusão de grupos sociais e espaços tais como favelas e periferias - que não condiziam com o imaginário de cidade pretendido, construído a partir da já conhecida representação da "Cidade Maravilhosa".

A lógica vigente no período - a qual enxerga a cidade como mercadoria - ignoraria o fato de que o espaço urbano é um complexo socioespacial que agrega diferentes leituras sobre seu entendimento e que reúne, em si, distintas formas de habitar. Nesta pesquisa, compartilha-se a definição de pensadores como Henri Lefebvre, de que a cidade seria um espaço plural, em constante transformação, ao qual compõese pela sociedade que nele habita e por distintas dimensões.

A partir deste contexto, o trabalho é desenvolvido em três partes, além desta introdução e das considerações finais. A primeira, apresentada no capítulo 2, objetiva construir o arcabouço teórico no qual a discussão irá se basear. Nela, serão 
tratadas questões tais como elementos ligados à essência da ideia de cidade, através de diferentes autores, tais como Lewis Mumford (1961), Henri Lefebvre (2006a, 2006b) e Françoise Choay (1965). Ainda no capítulo, busco pontuar questões fundadoras ao contexto contemporâneo das cidades, baseando-me, para tanto, em David Harvey (2013b; 2014; 2015), Ana Fani Carlos (2005; 2001; 2011), Otília Arantes (2002), Paola Jacques (2004; 2011a; 2013), dentre outros.

Colocadas tais questões, a intenção será traçar fundamentos para refletir sobre o espaço do Rio de Janeiro e delinear elementos que seriam importantes para sua produção. A partir de Henri Lefebvre (2006b), procuro pontuar que a cidade é um espaço em aberto, entendido como palco de disputa. Nele, por mais que haja pensamentos dominantes que procuram impor uma determinada forma de fazer a cidade, sempre haverá múltiplas maneiras de vivê-la e pensa-la. Para discutir sua finalidade e sentido, caberia compreender as práticas que se desenrolam através do espaço, considerando-se o ser humano como central no processo. Neste sentido, procuro pontuar elementos que poderiam contribuir para o entendimento sobre tal pluralidade. Para tanto, baseio-me na teoria de Lefebvre (2006a), sobre a produção do espaço, considerando, assim, olhá-lo através da tríade dimensional proposta. Parto de colocações do autor de que as representações construídas no espaço seriam tão importantes em sua (re)produção quanto o espaço material (espaço absoluto) e as relações sociais que se desenvolvem nele.

Traçado o ferramental teórico, serão apontadas diferentes representações desenvolvidas no - e sobre o - espaço urbano do Rio de Janeiro, entre o período de 2009 a 2016, tal como apontado acima. Por um lado, proponho um olhar sobre o espaço concebido, do "saber técnico", o qual buscaria construir a imagem-marca da cidade para divulga-la internacionalmente. Por outro lado, sugiro o olhar sobre representações referentes ao espaço vivido, construídas por moradores da Favela Nova Holanda sobre o cotidiano na escala local. Tal conteúdo é desenvolvido através dos dois capítulos subsequentes.

Ao longo do capítulo 3, a abordagem sobre a cidade carioca se dará a partir do olhar "oficial" construído para ela nos anos em questão. Primeiramente, delineio o contexto vivido no Rio de Janeiro, através da conjuntura que entendo ter influenciado diretamente na construção da imagem que se pretendia para a cidade. 
Defendo que a representação proposta se baseava no já conhecido imaginário da "Cidade Maravilhosa", e aponto, a partir daí três diferentes "frentes" construídas durante tais anos que pareciam buscar promover e consolidar a imagem-marca pretendida para o Rio de Janeiro. Dentre elas, descrevo em primeiro lugar, certas “estratégias de gestão de imagem" construídas por materiais publicitários. Em seguida, trago o exemplo da busca pela chancela da UNESCO para que a cidade se tornasse patrimônio da humanidade. Em terceiro, finalizo analisando intervenções urbanas ocorridas na região portuária.

Apesar das três abordagens apresentarem naturezas consideravelmente distintas entre si, todas se mostram próprias do tipo de pensamento que procura inserir os centros urbanos na "rede global de cidades". Ao longo de suas descrições, além de analisar elementos que elas buscariam destacar sobre o Rio de Janeiro, será pontuado também o que as três iniciativas pareciam querer ocultar sobre o espaço da cidade: é possível notar a busca por esconder o que se entendia como "problemas" do Rio de Janeiro - tal como os espaços de favelas.

No capítulo 4, em contraponto ao pensamento "oficial” que se construía, propõe-se olhar para a cidade a partir de representações construídas sobre a Favela Nova Holanda, no Complexo da Maré. Procuro pontuar, através de fotografias feitas por três moradores - Bira Carvalho, Elisângela Leite e Rosilene Miliotti -, o que as imagens do cotidiano destacam sobre características locais e, consequentemente, o que revelam sobre entendimentos do espaço urbano carioca. Tais representações, ao serem construídas a partir de espaços excluídos da "imagem oficial" da cidade, criariam contra-espaços e contra-projetos para a realidade cotidiana, as quais, segundo Lefebvre, apontariam não só para os desejos dos habitantes sobre a cidade, mas também poderiam indicar fundamentos para a transformação no espaço urbano.

Através de entrevistas semiestruturadas em profundidade e do conteúdo das fotografias, pontuo a visão colocada pelos fotógrafos ao longo de quatro assuntos "macro" que se destacaram ao longo da pesquisa: i) a forma de apropriação do espaço comum da Nova Holanda; ii) a pluralidade local e sua influência nas vivências locais; iii) o caráter dinâmico da conformação do espaço; iv) a 
importância de termos como "fé" e "resistência" no cotidiano e suas interferências no cotidiano e no espaço físico.

Ao trazer tais questões, propõe-se discutir a importância do olhar plural para a cidade a partir da escala humana, da vida cotidiana e da experiência corporal na cidade. Cabe destacar aqui que, este tipo de abordagem sobre o espaço urbano remonta à década de 1960, quando o grupo Internacional Situacionista e outros autores aqui tratados, defendiam a importância de se considerar as pessoas comuns e reais que estariam nas ruas das cidades para se pensar sobre ela.

Importante salientar também que a pesquisa parte do entendimento de que as favelas seriam uma categoria social central na discussão sobre a disputa pelo significado da ideia de cidade (BURGOS, 2010). Pelo seu histórico de resistência e por serem "expressão legítima do direito de habitar a cidade” (BARBOSA, 2014), elas constroem um outro ideal de cidade. Considera-se aqui que as favelas teriam práticas culturais criativas e ricas estratégias de construção do espaço desenvolvidas para suprir lacunas na oferta de direitos fundamentais. Nelas, diferentes condutas seriam desenvolvidas para melhorar a qualidade da vida cotidiana. Suas dinâmicas espaciais promoveriam outras formas de sociabilidades, outros encontros e experiência de "estar junto" (BARBOSA, 2014).

Vale destacar que, ao apontar vivências da Nova Holanda - e questionar estigmas endereçados a seu espaço -, entende-se as favelas não como "territórios desviantes" (ROLNIK, 1988) a serem curados e controlados, tal como foram historicamente abordadas (PERLMAN, 1977). Considera-se aqui que elas seriam espaços que denotam ordens distintas da imposta pela razão técnica dominante (SANTOS, 1988) e onde a organização espacial demonstra desejos dos habitantes sobre a cidade e a vida urbana. Para entrar em tal discussão, no entanto, acredito que o mais pertinente seria desenvolvê-la a partir da visão dos habitantes sobre seu próprio espaço.

Parto do entendimento, colocado por Lefebvre (2006b), de que a ação necessária para transformar a cidade seria designada "aos interessados", ou seja, às classes às quais se impõe a segregação do espaço e para as quais se nega o direito à cidade: nem arquitetos, nem economistas, filósofos, políticos ou sociólogos poderiam tirar "do nada, por concreto" novas formas e relações para o espaço. Apenas a vida 
social, em sua prática cotidiana, possuiria este poder, sendo que os profissionais supracitados poderiam contribuir para esta "renovação urbana" ao "limpar o caminho", propor formas, inventariar a experiência obtida, atentando-se sempre ao conjunto de significações percebidas e vividas pelos que habitam o local.

Neste contexto, a autorrepresentação construída por fotógrafos - tais como os três aqui abordados - se apresenta como uma potencial ferramenta de análise. Tais fotografias devem ser entendidas como "contra-representações", uma vez que irão questionar e desconstruir o que se pretende impor como próprio da Nova Holanda e da cidade, aquilo que seria reproduzido pelo discurso da mídia e do Estado. Entender o espaço - para, assim, pensar em seu futuro - passa por analisar sua multidimensionalidade e, consequentemente, por investigar suas representações (LEFEBVRE, 2006a). Neste contexto, falar sobre representações do espaço construídas pelos próprios habitantes, a partir de ferramentas como a fotografia, apresenta-se como uma maneira de compreender camadas ocultas do espaço urbano. Seria uma forma de se escutar aquilo que é silenciado pelo cotidiano segregado da cidade.

Antes de concluir, cabe destacar também algumas outras considerações sobre autorrepresentação e fotografia, elementos fundamentais da pesquisa. Como aponta Carminatti (2009), há um crescente fenômeno na produção de autorrepresentação visual em favelas e periferias do Rio de Janeiro através de vídeos, filmes, documentários e ensaios fotográficos. Nesta produção, o fotógrafo torna-se sujeito de sua própria imagem, o que permite que vejamos seu ambiente a partir do que ele, como habitante, quer destacar sobre seu espaço. Importante frisar que, aquilo que o fotógrafo registra vai além dos elementos registrados: a fotografia mostra o olhar do fotógrafo sobre o tema, revelando também o que não é visível. Como bem define Philippe Dubois (2015), a fotografia seria "traço de um real", e não a realidade em si. Apesar de entender que este aspecto denota certa parcialidade quando se fala sobre representação da cidade, considero que esta característica se mostra também como possibilidade de acesso a múltiplos pontos de vista (CARMINATTI, 2009) um contraponto importante no contexto de imposição de uma visão dominante. A fotografia, assim, torna-se uma ferramenta de denúncia, mobilização e 
desconstrução dos estereótipos das favelas como espaços meramente de violência e desordem.

O suporte fotográfico, cabe destacar também, é usado há séculos pelo campo da Arquitetura como recurso visual para a representação de grandes metrópoles (SOLÀ-MORALES, 2002). Da mesma forma, tem sido utilizado para a reflexão sobre os usos dos espaços de cidades tal qual foi feito Alison e Peter Smithson (1953) - a partir de fotografias de Nigel Henderson sobre a vida cotidiana de pessoas dos slums londrinos - e Ignasi de Solà-Morales, em Terrain Vague (2002).Também para o campo das Ciências Sociais, o recurso é usado como ferramenta de análise pelo potencial que apresenta para desvendar aspectos do imaginário social e das mediações nas relações sociais - questões cruciais para o entendimento do espaço. Os fotógrafos são considerados, a partir de um viés sociológico, como produtores de conhecimentos sociais, o que tornaria a fotografia um campo auxiliar da sociologia. Por ser flagrante, a imagem - sobretudo a fotográfica - é considerada valiosa por revelar as insuficiências da palavra como documento da consciência social, sendo um suporte que possibilitaria o cruzamento "verbo-visual" (MARTINS, 2016).

Considerando as questões colocadas aqui, procuro através da pesquisa promover a discussão sobre a pluralidade de vivências e percepções existentes no espaço urbano. Da mesma forma, busco abordar a importância de olharmos as experiências corporais e intervenções na escala da rua para pensarmos sobre propostas para a cidade. Procuro também testar alternativas de análise e reflexão sobre estas questões a partir de meios tais como as representações, assim como pelo olhar do habitante sobre seu espaço e considerando o espaço de favelas como ponto de origem para a reflexão sobre a cidade. Ensaio, aqui, propostas para o questionamento sobre a imposição de um "vir-a-ser" hegemônico da cidade, o qual limita o Rio de Janeiro à representação excludente da Cidade Maravilhosa. Afinal, a diversidade seria uma dimensão sem a qual o espaço não poderia ser imaginado (MELLO et al, 1985). 


\section{2 \\ Entendendo o contexto: uma revisão teórica sobre a produção do espaço}

Vivemos em um período de acelerado ritmo de urbanização mundial, no qual, segundo dados, setenta e cinco por cento da população viverá em centros urbanos por volta do ano 2050 (BURDETT \& SUDJIC, In: ROSA, 2011). Neste contexto, mostra-se cada vez mais urgente pensar-se sobre o tipo de cidade que queremos produzir e quais atores sociais pretendemos ser.

A partir de tal questão, proponho neste capítulo construir o arcabouço teórico que contribuirá para a discussão da pesquisa. Seu ponto inicial se coloca a partir do conceito de Direito à Cidade, de Henri Lefebvre (2006b). De forma sucinta, segundo o autor, a cidade seria um produto da sociedade que nela habita, tendo seus habitantes o direito não só de vivê-la - ou seja, habitá-la - plenamente, como também de transformá-la de acordo com suas demandas e desejos.

No contexto atual, como aponta David Harvey (2014), o direito à cidade "encontrase muito mais estreitamente confinado, na maior parte dos casos, nas mãos de uma pequena elite política e econômica com condições de moldar a cidade cada vez mais segundo suas necessidades particulares e seus profundos desejos" (HARVEY, 2014, p.63). E tal cenário tem sido visto também no Rio de Janeiro.

Antes de abordar a questão da capital carioca, busco traçar aqui alguns elementos para a discussão sobre o espaço urbano. Divido este capítulo em três partes. A primeira procura pontuar brevemente questões atreladas à essência da ideia de cidade, a partir de autores como Lewis Mumford (1961), Robert Park (1987), Lefebvre (2004, 2006b), entre outros.

A segunda parte busca traçar elementos que contribuíram para a atual organização do espaço urbano nas grandes cidades. Neste contexto, inicio abordando a constituição da cidade industrial, a qual se mostra essencial para apontar a conjuntura corrente. Em seguida, parto de autores contemporâneos, tais como 
Harvey (1993, 2013b), Arantes (2000), Jacques (2004, 2005, 2011a), entre outros, para abordar o contexto atual, no qual institui-se a noção de "cidade-mercadoria".

Já a terceira parte deste capítulo busca fundamentos sobre como o espaço seria produzido e quais as dimensões que compõem sua estrutura, usando para tanto, a teoria de Henri Lefebvre sobre a produção do espaço (2006a). A partir dela, busco colocar a importância das representações sobre o espaço para a compreensão da pluralidade da cidade. Em linha com Ana Fani Carlos (2005), acredito que "a cidade nos abre a perspectiva de entendermos o urbano, a sociedade, e a dimensão social e histórica do espaço urbano" (CARLOS, 2005, p.23). Neste contexto, como aponta a autora, para discutir o espaço urbano e formas futuras de pensá-lo, seria preciso resgatar as motivações estruturantes de sua origem, assim como também ler as dimensões ocultadas e as contradições existentes no espaço. Proponho aprofundar tal discussão nas páginas seguintes.

\title{
2.1 \\ Cidade: uma invenção do ser humano
}

\begin{abstract}
“A cidade, tal como é encontrada na História, é o ponto de máxima concentração do vigor e da cultura de uma comunidade. É o lugar onde vão concentrar-se os raios emitidos por muitos focos separados da vida, com proveitos tanto em eficiência como em significação social. A cidade é a forma e o símbolo de um conjunto integrado de relações sociais (...)." (MUNFORD, 1961)
\end{abstract}

De forma sucinta, Lewis Mumford (1961) resume diferentes questões relativas ao espaço urbano e que também são apresentadas por outros autores. Como bem resume Robert Park (apud HARVEY, 2013a, p.3), a cidade seria "a mais bemsucedida tentativa do homem de refazer o mundo onde vive de acordo com o desejo de seu coração". Em sua essência, segundo o autor, a cidade seria uma criação do ser humano construída para suprir diferentes dimensões de sua vida. Ela seria entendida como um espaço desenvolvido pelo desejo de um vir-a-ser da espécie humana.

Em outras palavras, a cidade seria a materialização no espaço de relações sociais entre pessoas, sendo o produto da ação de agentes históricos e sociais em meio às condições encontradas por eles. Mais do que um "amontoado de homens 
individuais e de conivências sociais", segundo Robert Park, ela seria "um estado de espírito, um corpo de costumes e tradições e dos sentimentos e atitudes organizados" (PARK, 1987, p.26). Seria mais do que mecanismos físicos e uma construção artificial: a cidade estaria envolvida nos processos vitais dos habitantes que a compõem.

Neste sentido, como aponta Henri Lefebvre (2006b), cada sociedade construirá o seu próprio espaço, de acordo com sua lógica societária. Podemos identificar tais diferenciações a partir da conformação física do espaço e do entendimento sobre seus usos cotidianos, por exemplo. Nas palavras de Mumford (1961), “o zimbório e a torre, a avenida aberta e o pátio fechado contam a história não apenas de diferentes acomodações físicas, mas de concepções essencialmente diferentes de destino do homem" (MUMFORD, 1961, p.15).

Consequentemente, os "destinos do homem" e as diferentes concepções de vida impressos na conformação do espaço resultarão em distintas categorias de cidade ao longo da história, as quais revelariam funções diversas entre si. Henri Lefebvre (2006b), ao descrever organizações espaciais de cidades até a década de 1960, as encaixa em três categorias: a cidade politica, a cidade mercantil e a cidade industrial. Ao longo de sua explanação sobre o assunto, o autor aponta para suas diferenças não só a partir de conformações físicas, mas principalmente sobre as funções sociais cruciais que exerceriam a seus cidadãos, sublinhando ainda os aspectos econômicos e históricos que também determinariam a sua construção.

Dentre as distintas cidades "categorizadas" ao longo da história, cabe destacar aqui uma em especial: a "cidade industrial”, a qual começaria a se consolidar a partir do surgimento da indústria fabril e de sua entrada na cidade. Segundo Lefebvre, seu advento irá mudar consideravelmente a estrutura do que antes se entendia como "essência" de cidade. Se os espaços urbanos anteriores tinham o caráter de serem construídos como "obra"1 - ou seja, um espaço construído por seus habitantes a partir dos anseios e desejos do ser humano -, o espaço criado pela chamada

1 Para o autor, a cidade criada na idade media ocidental teria o caráter de "obra", "a ser associada mais com a obra de arte do que com o simples produto material. Se há uma produção da cidade, e das relações sociais da cidade, é uma produção e reprodução de seres humanos por seres humanos, mais do que uma produção de objetos. A cidade tem história; ela é a obra de uma história, isto é, de pessoas e de grupos bem determinados que realizam essa obra nas condições históricas" (LEFEBVRE, 2006b, p.46-47). 
"sociedade industrial” irá pautar-se pelas determinações da produção material: as cidades passam aí a pertencer não mais aos citadinos, mas ao capital. Como resume Carlos (2005), a partir daí a cidade não seria mais o lugar do encontro - como eram as cidades anteriores -, mas o espaço marcado pela ausência de comunicação, das relações fragmentadas. O tempo, entendido em um primeiro nível como as horas do dia, passa a determinar as atitudes e as atividades dos habitantes através de um ritmo intenso e incessante.

Os espaços seriam, a partir daí, pedaços a serem vendidos, tal como mercadorias. O espaço da festa, do encontro, da praça, das crianças que brincam na rua, são substituídos continuamente por outros espaços e outras finalidades. O desenho urbano e as formas arquitetônicas passam a segregar, apartar e a estabelecer fronteiras virtuais entre espaços próprios para cada esfera social (CARLOS, 2005). A partir do cotidiano da cidade industrial ${ }^{2}$, vemos a separação entre homemnatureza, o individualismo exacerbado e a fragmentação de diversos níveis da vida. A cidade passa a ser vista como uma solução racional para a eficiência dos meios produtivos.

Como defende Aldo van Eyck (apud RYKWERT, 2006), porém, este não deve ser o único olhar sobre os centros urbanos: a cidade deve cultuar as esperanças e os temores de seus cidadãos. Afinal, elas teriam sido construídas para que os seres humanos pudessem reconhecer-se, agregando assim, diferentes desejos e formas de habitar.

Ao negar tal pluralidade e as funções primárias de conformação do espaço urbano, nega-se a seus distintos habitantes o que Lefebvre (2006b) chamou de Direito à Cidade. Ou seja, o direito do citadino de viver a cidade plenamente e de transformála de acordo com suas demandas passa a ser negado àqueles a quem ela deveria servir. Se, de acordo com a colocação supracitada de Park (apud HARVEY, 2013a), a ideia de cidade estaria ligada à tentativa do ser humano de refazer o mundo em que vive de acordo com os seus próprios desejos, caso o espaço urbano não se

\footnotetext{
2 Cabe pontuar aqui que, como aponta Lefebvre, o cotidiano caracteriza a sociedade e apresenta-se como o caminho mais racional para compreendê-la. O cotidiano poderá desenrolar-se através de repetições lineares e cíclicas de uma racionalidade imposta à dimensão de tempo na cidade, porém, poderá, igualmente, aparecer como o lugar da confrontação, o qual, segundo Carlos (2005), "emerge na luta entre o permanente e o mutável; entre o racional e o irracional" (CARLOS, 2005, p.23). O cotidiano será uma construção da sociedade, segundo sua ordem.
} 
encontre alinhado às aspirações dos indivíduos, a transformação da cidade torna-se uma necessidade.

O direito à cidade é, portanto, muito mais do que um direito de acesso individual ou grupal aos recursos que a cidade incorpora: é um direito de mudar e reinventar a cidade mais de acordo com nossos mais profundos desejos. Além disso, é um direito mais coletivo do que individual, uma vez que reinventar a cidade depende inevitavelmente do exercício de um poder coletivo sobre o processo de urbanização. (HARVEY, 2014, p.28)

Tal como supracitado, a conformação que o espaço passava a ter a partir do período da sociedade industrial, geraria profundas transformações na organização como as cidades estavam estruturadas anteriormente, influenciando também a maneira como o espaço urbano passaria a ser entendido e construído. Pela influência do período também nas cidades atuais, proponho aprofundar a seguir a discussão sobre a organização espacial da cidade industrial a partir do século XIX.

\section{2}

\section{A cidade como máquina}

Os séculos XIX e XX foram marcados por um grande crescimento demográfico das cidades, o qual seria consequência dos progressos científicos e técnicos realizados a partir da metade do século XVIII ${ }^{3}$ (HAROUEL, 2004). Como aponta Lefebvre (2006b), o processo de industrialização seria o "ponto de partida" para a reflexão sobre a sociedade moderna. A partir dele, a cidade passaria a perder seu caráter de "obra" para ser vista como um "produto". Nesse contexto, o espaço urbano em si seria destinado à produção de mercadorias e à troca das mesmas, prevalecendo o "valor de troca" sobre o "valor de uso" ${ }^{4}$, antes preponderante.

A indústria estaria, assim, ligada à não-cidade, à ausência e ruptura da vida urbana existente. Ao adentrar a cidade, irá fazê-la "explodir" no século XIX, como ilustra Lefebvre (2004), estendendo rapidamente o tecido urbano ${ }^{5}$, e recobrindo

3 As cidades da Europa Ocidental seriam as responsáveis por desencadear o processo, sendo seguidas pelas cidades dos Estados Unidos.

4 De forma sucinta, ao definir os termos, Lefebvre pontua que: "Em particular, a oposição entre o valor de uso (a cidade e a vida urbana, o tempo urbano) e o valor de troca (os espaços comprados e vendidos, o consumo dos produtos, dos bens, dos lugares e dos signos) surgirá em plena luz." (LEFEBVRE, 2006b, p.27)

5 Lefebvre define o termo "tecido urbano" como "unidade coerente constituída ao redor de uma ou de várias cidades, antigas e recentes". O essencial, porém, estaria em entender que o tecido urbano não se limita à sua morfologia, mas sim que é o suporte de um modo de viver (Lefebvre, 2006b). 
integralmente a cidade anterior. À toda a sociedade será imposto o modo de viver da sociedade urbana. Lefebvre apontará para o processo de implosão-explosão, que ocorrerá no contexto: nele, ao mesmo tempo em que surge uma enorme concentração de pessoas, atividades, riquezas, objetos, meios, pensamentos, etc., haverá também uma imensa explosão, que projeta fragmentos diversos e disjuntos, criando as periferias, subúrbios, cidades satélites, entre outros.

Dentre as diferentes correntes ${ }^{6}$ de pensamento que buscavam elaborar propostas de "ordem" para as "cidades doentes" - característica decorrente de seus aumentos demográficos -, a corrente progressista tornar-se-á o principal modelo do urbanismo moderno (HAROUEL, 2004). Seus autores ${ }^{7}$ teriam em comum a concepção sobre o homem e a razão, entendendo que a ciência permitiria um modelo urbano perfeito a todo o grupo humano. O humano é entendido como um "tipo", independente de suas origens geográficas ou temporais, tendo também as necessidades-tipos cientificamente dedutíveis (CHOAY, 1965).

Um certo racionalismo, a ciência, a técnica devem possibilitar resolver problemas colocados pela relação dos homens com o meio e entre si. Esse pensamento otimista é orientado para o futuro, dominado pela ideia de progresso. A revolução industrial é o acontecimento histórico-chave que acarretará o devir humano e promoverá o bem-estar. Essas premissas ideológicas permitirão que chamemos de progressista o modelo que inspiram. (CHOAY, 1965, p.8)

A ordem-tipo determinada pela corrente será, assim, suscetível de ser aplicada a qualquer lugar, sociedade e tempo. O planejamento dos lugares resultará em espaços estruturados em zoneamentos disjuntivos, acarretando não apenas na segregação do tempo dos habitantes, como também na diversidade existente de organização da vida. Ou seja, além de criar uma nova configuração espacial, o rápido processo de expansão do tecido urbano irá provocar também novos arranjos nas relações sociais. Ao fragmentar o espaço através de um zoneamento que separa a cidade por "funções", tais como trabalho, lazer, moradia, irá também segmentar a organização do cotidiano e restringir diferentes modos de vida. Tal "morfologia material", ao determinar sua organização, caminhava no sentido de transformar a cidade em instrumento de exploração; buscava também exaltar uma suposta

6 Tal como aponta Choay (1965), haveriam as correntes progressistas, humanistas e naturalistas. 7 Choay (1965) segmenta o "modelo progressista" entre os pensadores do período "pré-urbanismo", no século XIX, tais como Fournier, Owen, Richardson, Cabet e Proudhon, e os pensadores/arquitetos do período do "urbanismo", no século XX, como Garnier, Le Corbusier, Gropius, entre outros. 
homogeneidade através da segregação dos grupos sociais para, com isso, silenciar as disputas pelo próprio espaço, criando um espaço de dominação.

Baseando-se na corrente progressista, o plano modernista para a cidade industrial concretizaria, segundo Lefebvre (2004), as ideias destinadas à sociedade industrial. O autor defende que o urbanismo, ao seguir ideologias autoritárias sem contestá-la, teria contribuído para a criação de ordens sociais a partir da lógica de "homogeneidade - fragmentação - hierarquização". Le Corbusier, por exemplo, é duramente criticado em diferentes textos de Lefebvre $(2004$; 1969; 2006a) por reduzir a sociedade urbana a algumas poucas funções que acreditava poderem ser previstas e transcritas pela prática da Arquitetura: habitar, trabalhar, locomover-se, cultivar o corpo e o espírito ${ }^{8}$.

Para se entender o caminho tomado pelo projeto do plano modernista, vale pontuar brevemente como o contexto histórico e social já vinham demandando mudanças na disciplina durante o século XIX. Com a Revolução Industrial e a modernização social acelerada, a arquitetura e o planejamento urbano se veem frente à uma nova situação: surgem novas esferas da vida, que exigem novas bibliotecas, escolas, novas redes de transporte, novas formas de circulação de mercadorias que atendessem às grandes cidades e ao consumo em massa. Vê-se também a miséria social do início da industrialização, o movimento revolucionário dos trabalhadores, entre outras questões sociais que surgiam no contexto em questão. Novos materiais e novos métodos de construção passam a serem usados, revolucionando também as noções visuais. As leis de mercado da construção e da moradia transformavam a relação com o construir e o morar; os imperativos econômicos traziam um crescimento incontrolado das cidades. Neste contexto, a estrutura urbana das cidades mercantis já não fazia mais sentido (HABERMAS, 1987).

\footnotetext{
${ }^{8}$ Por mais que as críticas de Lefebvre aqui destacadas direcionem-se diretamente à Le Corbusier, cabe frisar que tais colocações foram defendidas a partir da Carta de Atenas, formulação doutrinária proposta pelo grupo dos C.I.A.M. (Congressos Internacionais de Arquitetura Moderna), em 1933, no quarto congresso (CHOAY, 1965). O grupo, formado por seguidores da corrente progressista (grupo no qual Corbusier tinha grande destaque), é defensor de uma nova arquitetura à base de formas puras, influenciada diretamente pelo cubismo (HAROUEL, 2004). Segundo Choay (1965), ao abordar o pensamento do grupo. aponta que "a cidade do século XX precisa realizar, por sua vez, a revolução industrial: e não basta empregar sistematicamente os materiais novos, aço e concreto, que permitem uma mudança de escala e de tipologia; é preciso, para obter a "eficácia" moderna, anexar os métodos de estandartização e de mecanização da industria" (CHOAY, 1965, p.20).
} 
Como coloca Habermas (1987), para além de tais fatos, para abordar o impulso através do qual nasce a Arquitetura Moderna, é preciso ter presente que tal campo, na segunda metade do século XIX não conseguiu superar nenhum dos desafios surgidos durante tal contexto histórico. O Movimento Moderno, em meio ao cenário, decidira "abraçar" os desafios que surgiam no momento, procurando, assim, não se limitar à questão edificativa, mas também abranger a totalidade da vida social e da prática cotidiana ${ }^{9}$.

Le Corbusier, um dos principais nomes do movimento, irá pautar, neste contexto, o pensamento modernista: para ele, o mundo poderia ser revolucionado através da Arquitetura, sendo o projeto, a "chave" de tal "batalha". O mundo, em sua concepção, não teria conflitos, pluralidades ou dissensos. Todas as questões urbanas, fossem referentes à esfera material ou social, poderiam ser resolvidas através da ideia de projeto.

Ainda conforme o autor, a transformação do espaço urbano dependeria de seu grau de organização. Para ele, a ordem seria um fator imprescindível para a existência de qualquer cidade. Com os avanços dos meios técnicos, seria possível, finalmente, contribuir para que tal "ordem" fosse atingida, promovendo, consequentemente, o "progresso" das cidades.

Inclui-se nessa visão o pressuposto de que as máquinas, que vinham sendo produzidas em diferentes partes do mundo, dariam ao homem um poder ilimitado. Através delas, "apesar de tão pequeno", o ser humano poderia se tornar grandioso e realizar sonhos através de seu uso ${ }^{10}$. Na visão de Corbusier, o passado havia gerado o caos, mas o poder ilimitado que tais máquinas possibilitavam, poderia fazer com que a desordem existente fosse "superada" (CORBUSIER, 2000).

9 Cabe pontuar, porém, que por mais que não "abraçado" em sua totalidade pela Arquitetura até o momento descrito acima, Leon Battista Alberti já tratava do papel social do arquiteto em "Da Arte de Construir - Tratado da Arquitetura e Urbanismo" (1485). Para o autor, a arquitetura seria essencial para "reunir e manter unidos os seres humanos". Segundo ele, o arquiteto fornece abrigo seguro e confortável, como também realiza inúmeras invenções que se tornam de utilidade tanto pública, quanto privada. Ao buscar um ator principal para quem a arquitetura trabalha, Alberti defende, mais uma vez, a grandiosidade da profissão, apontando ser essencial tanto para "o governo ou o cidadão, a religião ou a vida profana, o trabalho ou o ócio, cada um individualmente ou a humanidade inteira". É interessante notar que Alberti coloca que, independente de para quem seja, a arquitetura tem um propósito comum para fornecer a todos eles: o bem-estar.

10 Através da narrativa de tal projeto, é possível perceber como o projeto de arquitetura moderno se pauta no futuro para desenvolver suas propostas, e não mais no tempo passado, como fazia Alberti e seus "seguidores". 
Em tal pensamento, cabe pontuar, a cidade, em si, seria uma complexa peça de maquinário na qual peças de robótica a serem conectadas representavam exatamente a visão modernista de cidade: "a noção de que pudesse haver algo 'simbólico' na tessitura da cidade parecia quase uma frivolidade ofensiva" (RYKWERT, 2006, p. XLVIII). Seu funcionamento dependeria não apenas de sua semelhança com um motor, mas suas funções deveriam ser ordenadas, classificadas e divididas em zonas disjuntas, podendo, assim, funcionar de forma mais eficiente.

Em seu projeto, através de uma sistemática cientificista pautada nas categorias "classificar - ordenar - reclassificar", pretendia-se "resolver o problema" do caos da cidade, reduzindo, para tanto, o espaço urbano ao mínimo possível. O controle proposto em seu plano de cidade entra precisamente em todos os detalhes do espaço urbano: no traçado das ruas (para ele, os centros urbanos estariam morrendo por não serem geométricos), na distribuição entre as áreas, na definição da densidade da cidade e dos tipos de transporte que os habitantes deveriam utilizar ${ }^{11}$.

Uma das críticas que se coloca sobre o plano modernista de cidade é relativa à homogeneidade construída ao determinar-se um modelo único e homogêneo de cidade e cidadão, o qual seria imposto ao conjunto da sociedade como regra. $\mathrm{O}$ projeto da cidade contemporânea de Corbusier separaria e hierarquizaria os grupos sociais por função ou necessidade cotidiana: haveriam os urbanos, os suburbanos e os mistos. A delimitação de áreas da cidade também passaria a ser ordenada através de zoneamentos traçados por funções e hierarquizadas, havendo assim, espaços residenciais, comerciais, de lazer, os espaços para os marginais, etc. Desta forma, estabeleciam-se espaços com mais valor do que outros (LEFEBVRE, 2006a). A ideia de "conjuntos", muito presente nas propostas urbanas, criavam fragmentações em lotes, parcela, que produziam guetos e pseudo-conjuntos mal ligados aos arredores e aos centros. Seu intuito seria, na visão de Henri Lefebvre (2004), o de realizar a dominação dos indivíduos, criando uma forma de melhor hierarquizar a extensão da cidade.

11 Corbusier (2000) pretende definir, inclusive, o nível de pureza de ar que os citadinos respirariam e o grau de conforto necessário para os habitantes (definindo, consequentemente, o que eles deveriam entender pela palavra). Seu projeto determina também a quantidade de tempo que o indivíduo deve descansar e como deve fazê-lo: oito horas de repouso continuado, em que, neste tempo, o homem deverá fazer esportes - e que fosse perto de casa (CORBUSIER, 2000). 
A partir de tal ordenação espacial seria possível estabelecer a "cotidianidade": um "lugar social de uma exploração refinada e de uma passividade cuidadosamente controlada", que se instaura "na e pela segregação generalizada: a dos momentos da vida, como a das atividades" (LEFEBVRE, 2004, p.129). O conceito da cotidianidade $^{12}$ era apresentado em textos publicitários como "um conto de fadas", descrito de tal maneira que deixa nítida a imagem do que deveria significar a "alegria de viver"13. Tal sociedade do consumo iria se traduzir em ordens, seria pautada por uma ideologia da felicidade através do consumo, a qual a faria acreditar na alegria de ter um urbanismo que programa sua cotidianidade, que ordena seu espaço e que, assim, a permite alcançar a "satisfação".

Neste pensamento sobre o espaço urbano, o qual construiria os centros comerciais e os centros de consumo, seriam também projetados os centros decisionais no qual se concentram meios de poder e repressão, os mesmos que também repartem a periferia em ordens dispersas (segundo normas e coações) com sua "urbanização desurbanizada" (LEFEBVRE, 2006b). Reunidas, tais "tendências" de reflexão urbana esboçariam a estratégia global construída para a sociedade: com todas as condições reunidas, seria possível que houvesse uma dominação perfeita, "para a exploração apurada das pessoas", segundo Lefebvre (2006b), de forma que pudessem ser ao mesmo tempo produtores, consumidores de produtos e consumidores de espaço.

Na sociedade em questão (dita de consumo), o que se consumiria, na realidade seria o signo do real, e não a realidade em si. Nela, o mundo seria transformado em objeto e oferecido como espetáculo para alimentar um "consumo devorador". O espetáculo, como define Guy Debord (2015), seria uma relação entre as pessoas,

\footnotetext{
12 Segundo Martins (2016), "os mecanismos sociais de prevalência do repetitivo em relação ao transformador, já nos primeiros anos após a Segunda Guerra Mundial, como observou Henri Lefebvre, trouxeram a vida cotidiana para o primeiro plano da existência da maioria das sociedades ocidentais e instituíram a cotidianidade como a era de um modo de ser dominado pelo presente, pelo fragmentário e pela incerteza" (MARTINS, 2016, p.35).

$13 \mathrm{O}$ autor ilustra tal ideia ao descrever exemplos de publicidades de vendas de imóveis, que sob os slogans "faz nascer uma nova arte de viver" e "um novo estilo de vida", apresentava o que seria este tipo ideal: "'Deixar seu casaco no vestiário da entrada e, mais leve, dar suas caminhadas após ter deixado as crianças no jardim de infância da galeria, encontrar os amigos, tomarem um drink no bar'". Uma descrição que traduziria uma sociedade guiada pela ordem, não só presente no espaço e no tempo fragmentados, mas que também dita como e o que é ser feliz.
} 
mediada por imagens. Ou seja, o que antes era vivido diretamente, passa a ser substituído por uma mera representação.

Neste "mundo", o espetáculo criado seria o discurso que a ordem faria sobre si mesma; seria, ao mesmo tempo, o resultado e o projeto do modo de produção existente, um instrumento de unificação que concentra o olhar e a consciência. Ele expressaria o que a sociedade poderia fazer, estabelecendo o permitido frente ao possivel. Sua forma de alienação é construída à medida que o espectador contempla o objeto e se reconhece nas imagens criadas sobre as necessidades. Desta forma, o indivíduo compreenderia cada vez menos sua existência e seu próprio desejo. Como aponta Debord, "quanto mais sua vida se torna um produto, mais ele se separa dela" (DEBORD, 2015, p.25). A vida urbana construída na cidade industrial se pautaria cada vez mais pela pobreza das necessidades sociais, construída através do consumo cotidiano e dos signos da publicidade e da moda.

Neste projeto da cidade moderna, a essência da rua passaria a ser completamente suprimida, perdendo seu caráter de lugar do encontro, do movimento e da mistura. Nega-se, assim, sua função informativa, simbólica, lúdica, do espaço que informa e surpreende. A rua se torna o espaço do fluxo dos automóveis e da mercadoria, servindo exclusivamente ao novo modelo de vida dominante na sociedade: o espetáculo. Sua função passa a ser a de possibilitar deslocamentos entre os diferentes momentos da cotidianidade. A circulação dos pedestres seria ainda tolerada pela possibilidade de perceberem as vitrines e comprarem os produtos expostos.

Neste novo rearranjo da cidade moderna, o "habitar"14 tornar-se-ia restrito, uma vez que o habitante não participaria mais da vida social em comunidade. A vida urbana,

\footnotetext{
14 Ao abordar os termos "habitar" e "habitat", Lefebvre (2004) aponta que: "Sem medo de recair numa controvérsia já longa, colocaremos fortemente em oposição o habitar e o habitat. Este ultimo, um conceito, ou melhor, um pseudoconceito caricatural. No final do século XIX, um pensamento (se é possível dizer) urbanístico, tão forte quanto inconscientemente redutor, pôs de lado e literalmente entre parênteses, o habitar. Ele concebeu o habitat, função simplificada, restringindo o 'ser humano' a alguns atos elementares: comer, dormir, reproduzir-se (...). Antes do habitat, o habitar era uma prática milenar (...). No reino do habitat, desapareceu do pensamento e deteriorouse fortemente na prática o que fora o habitar (...). O habitat, ideologia e prática, chegava inclusive a reprimir as características elementares da vida urbana, constatadas pela ecologia mais sumária: a diversidade das maneiras de viver, dos tipos urbanos, dos 'patterns', modelos culturais e valores vinculados às modalidades ou modulações da vida cotidiana. $\mathrm{O}$ habitat foi instaurado pelo alto: aplicação de um espaço global homogêneo e quantitativo obrigando o 'vivido' a encerrar-se em caixas, gaiolas, ou 'maquinas de habitar'” (LEFEBVRE, 2004, p. 80-81).
} 
antes caracterizada por este "habitar", ou seja, pelos encontros e confrontos, pelas diferenças, é transformada pela repartição da vida cotidiana, passando a pautar-se pelo "habitat".

A espontaneidade não teria espaço em tal ordem. O habitat, enquanto ideologia e prática, contribuiria para a homogeneização da sociedade: reprimiria a diversidade das maneiras de viver, dos tipos urbanos, de modelos culturais e valores vinculados às modalidades ou modulações da vida cotidiana. Instaurado a partir da construção de um espaço homogêneo, o habitat passava a obrigar a dimensão do espaço experienciado a fechar-se em gaiolas, caixas, em verdadeiras "máquinas de habitar" (LEFEBVRE, 2004, p.81).

Cabe pontuar que o habitar, mesmo com ressalvas, pode ser assimilado ao inconsciente colocado por psicanalistas e psicólogos, segundo Lefebvre (2004). Para entendê-lo, seria preciso ir além dos simbolismos criados sobre o espaço, ou seja, em direção ao desconhecido da cotidianidade. Como aponta Heidegger ao citar Holderlin (apud LEFEBVRE, 2004, p.81) "o homem habita como poeta". Se não lhe é dada a possibilidade de habitar poeticamente, ele a fabricará à sua maneira. Mesmo o cotidiano mais irrisório teria o vestígio de grandeza e desta poesia espontânea. A menos, porém, que o mesmo seja a pura aplicação da publicidade e da encarnação do mundo da mercadoria.

Esta característica mostraria que o ser humano teria, segundo Lefebvre (2004), a natureza da contradição, seria composto pelo desejo e razão, espontaneidade e racionalidade. As necessidades sociais inerentes ao ser humano seriam muito mais amplas do que as consideradas pelo valor de troca, pelo comércio e pelo lucro. Teriam fundamento antropológico, sendo, ao mesmo tempo opostas e complementares: compreenderia a necessidade da certeza e da aventura, da unidade e da diferença, do isolamento e do encontro. "Tem necessidade de ver, ouvir, de tocar, de degustar, e a necessidade antropológica de reunir essas percepções num 'mundo"' (LEFEBVRE, 2006b, p.103). Haveria também a necessidade de uma atividade criadora, de obra, de imaginário, de atividades lúdicas. As necessidades urbanas específicas seriam as necessidades de lugares de simultaneidade e de encontros. 
Neste contexto, o habitar não deve ser estudado como resíduo de níveis ditos "superiores", mas sim, ser considerado como fonte, fundamento. Diante de cidades transformadas em espetáculos para o consumo, Lefebvre sentencia:

Eis uma vida quotidiana bem decupada em fragmentos: trabalho, transporte, vida privada, lazeres (...). Eis o ser humano desmembrado, dissociado. Eis os sentidos, o olfato, o paladar, a visão, o tato, a audição, uns atrofiados, outros hipertrofiados. Eis, funcionando separadamente, a percepção, a inteligência, a razão. Eis a palavra e discurso, o escrito. Eis a quotidianeidade e a festa, esta última moribunda. Com toda a certeza, e com a máxima urgência, é impossível continuar nessa situação. (LEFEBVRE, 2006b, p.97-98)

\section{3}

\section{A cidade como mercadoria}

A crítica de Lefebvre sobre a organização da cidade moderna mostra-se pertinente ainda nos dias de hoje. A realidade fragmentada dos espaços urbanos continuaria pautando as relações sociais e o cotidiano dos indivíduos, ou seja, ainda teriam vínculos com a produção de capital e divisão do trabalho. A organização atual, porém, passa a ter algumas diferenças, uma vez que, na fase atual do capitalismo, "as cidades passam elas mesmas a ser geridas e consumidas como mercadorias" (ARANTES, 2000, p.26).

No processo atual, como coloca o geógrafo David Harvey (2013b), a organização espacial de diversas cidades - assim como o Rio de Janeiro - poderia ser definida como "um mundo em que a ética neoliberal de individualismo, acompanhada pela recusa de formas coletivas de ação política, se torna o modelo para a socialização humana". Segundo o autor, a expansão do processo de urbanização recente ${ }^{15}$ tem provocado mudanças no estilo de vida dos indivíduos, fazendo com que a qualidade da vida nas cidades se transforme em mercadorias: o consumismo, o turismo, a indústria cultural e do conhecimento tornam-se aspectos da economia urbana.

Paola Jacques (2004), por sua vez, defende que a maneira como o mundo vem sendo construído hoje - ainda o mesmo de um espaço urbano baseado no capital - faz parte da dinâmica de espetacularização das cidades contemporâneas, uma

15 Assim como em outros momentos da história, tais como com Haussmann (Paris, 1853) e Moses (Nova Iorque, década de 1940), por exemplo, teriam influenciado mudanças dentro de suas devidas proporções. 
consequência do que Guy Debord (2015) apontava como "sociedade do espetáculo". Segundo Jacques (2004), em tal processo de espetacularização dos centros urbanos existiriam duas correntes de pensamento sobre a cidade hoje que convergiriam para o espetáculo. A primeira, a mais conservadora, ao radicalizar a preocupação pós-moderna sobre as culturas pré-existentes, acabaria provocando uma petrificação ou o "pastiche do espaço urbano", levando-o - principalmente os centros históricos - à museificação e patrimonilização. A segunda corrente, mais progressista, baseando-se em princípios modernistas como o da tábula rasa ${ }^{16}$, defenderia o projeto da grande escala, de espaços geralmente periféricos ou de cidades de periferia mundial - conhecidas como, por exemplo, a Cidade-Shopping ou a Cidades Genéricas, como define o arquiteto Rem Koolhaas (2010).

Apesar de suas diferenças, ambos os discursos se pautam na ideia do espetáculo para a construção das cidades. Ambos, também, têm coexistido na prática nas cidades contemporâneas, sendo, muitas vezes, conduzidos pelos mesmos atores e patrocinadores que procuram, assim, transformar os centros históricos em receptáculos de turistas, e usar a expansão periférica como produto para a especulação imobiliária. Por mais que se originem de discursos distintos, o objetivo principal de todo este processo é a mercantilização das cidades (JACQUES, 2011a).

Segundo Jacques (2011a), o que estaria sendo proposto, ao se produzir tais políticas e projetos urbanos contemporâneos seria a criação de uma "imagem-marca" da cidade, ou seja, uma representação que a divulgue internacionalmente, fazendo com que tais centros urbanos possam, assim, "pertencer à geopolítica das redes globalizadas de cidades turísticas, históricas ou culturais" (JACQUES, 2011a, p.162).

Esta dinâmica, segundo Otília Arantes (ARANTES, 2000), teria origem na mudança de pensamento sobre a cidade, iniciada após o colapso da modernidade

16 A "tábula rasa", princípio caro aos arquitetos modernos, propunha a ruptura com o passado e o legado histórico para que o poder transformador do campo da arquitetura se tornasse possível. O princípio seria a condição básica para a introdução de uma nova ordem de cidade, considerada a ideal. Entendia-se que as condições vividas no momento seriam inéditas em relação ao passado, sendo assim necessário livrar o homem de laços sentimentais de tempos anteriores para que o novo pudesse ser executado. Sobre os antigos centros urbanos, projetavam-se, assim, as supracitadas cidades zonificadas. No contexto atual, o princípio seria aplicado nas chamadas "Cidades Genéricas", segundo Rem Koolhaas: "(...) todas as Cidades Genéricas surgem da tábula rasa; se não havia nada, agora elas estão lá; se já existia algo, elas substituiram-no. Teriam que ser assim, de outro modo, seriam históricas" (KOOLHAAS, 2010, p.44) 
urbana, e pautada pela lógica empresarial. Para Arantes (2000), ao menos a partir dos anos 1990, quem "faz a cidade" são as grandes empresas, com as mediações de praxe. O que regeria as ações para este espaço urbano seria a convergência entre governantes, burocratas e urbanistas em torno de uma espécie de "teorema-padrão", uma crença de que as cidades devem ser protagonistas na chamada "rede globalizada", resultando em um quadro de competição entre cidades. A cidade passa, neste contexto, a ser entendida como "cidade-mercadoria" - aquela que deve vender-se, que passa a ser um produto a ser negociado - e "cidade-empresa" aquela que será gerida como uma empresa privada competente e que se tornará palco de negócios (MARICATO, 2001).

Cabe aqui colocar que tais conceitos estão ligados à noção de "cidadeempreendimento" que, como aponta Peter Hall (1988), teria surgido na década de 1970, quando "o planejamento deixou de controlar o crescimento urbano e passou a encorajá-lo por todos os meios possíveis e imagináveis" (HALL, apud ARANTES, 2000, p.20). Nas palavras de Hall,

Cidades, a nova mensagem soou em alto e bom som, eram máquinas de produzir riqueza; o primeiro e principal objetivo do planejamento devia ser azeitar a máquina. O planejador foi-se confundindo com o seu tradicional adversário, o empreendedor; o guarda-caça transforma-se em caçador-furtivo. (HALL, 1988, p.407)

A "fórmula salvadora" que permitiria tamanha obsessão por crescimento viria dos Estados Unidos, onde o planejamento regulamentador nunca havia sido realmente forte, onde a tradição da livre iniciativa sempre havia predominado (HALL, 1988). Neste contexto, seriam trazidas também noções como "revitalização urbana" e seus derivados, tais como a ideia de "parceria" entre setor público e iniciativa privada (ARANTES, 2000).

A ferramenta que tornaria possível levar qualquer cidade ao pódio da "rede globalizada de cidades" seria o chamado "Planejamento Estratégico", termo próprio do meio empresarial, que aponta para o caráter do pensamento usado. Através dele, argumenta-se que seria possível gerar respostas competitivas aos desafios da globalização. A lógica defendida seria de que as cidades deveriam ser geridas não apenas ''like business' (como negócios), mas antes 'for business' (para os negócios)" (ARANTES, 2000, p.28), atendendo assim a demandas de um capital 
escasso e nômade, característico do momento de retomada da hegemonia americana (conhecido como "globalização").

Neste cenário, para inserir-se na "geopolítica das redes globalizadas de cidades", os centros urbanos deveriam instrumentalizar-se para, assim, poder competir na disputa por investimentos. Ao tornar-se uma "máquina urbana de produzir renda", a cidade deveria agir estrategicamente para tal fim, buscando consensos e esforços de todos em torno da visão que o planejamento estratégico apontasse para seu futuro. Como um primeiro passo, a cidade deveria preparar-se para apresentar serviços e equipamentos demandados pelo capital transnacional, tais como aeroportos internacionais, hotéis de luxo com segurança adequada, espaços de convenção e feiras, pólos de pesquisa tecnológica, entre outros. Desta maneira, a cidade estaria apta a vender-se com competência (MARICATO, 2001). Como apontam Borja e Castells (1996) ${ }^{17}$,

O governo local deve promover a cidade para o exterior, desenvolvendo uma imagem forte e positiva apoiada numa oferta de infra-estruturas e de serviços (comunicações, serviços econômicos, oferta cultural, segurança etc.) que exerçam a atração de investidores, visitantes e usuários solventes à cidade e que facilitem suas "exportações" (de bens e serviços, de seus profissionais etc.). (CASTELLS \& BORJA, 1996, p.160)

O sucesso na competição pelo mercado internacional dependeria também de uma boa estratégia de marketing urbano. Para tanto, o planejamento estratégico iria definir a "vocação" do centro urbano, ou seja, qual "talento" a cidade possuiria para vender-se no cenário mundial. Este papel, ao ser definido, seria o responsável por guiar a construção de sua imagem-marca e de sua configuração sócio-espacial: a "vocação" deveria, assim, definir a maneira de se "fazer" a cidade.

Desta forma, seria possível criar slogans singulares para a disputa por turistas e investimentos no acirrado mercado internacional. O marketing urbano passa, neste contexto, a ser usado cada vez mais pelos governantes locais como uma esfera específica e determinante do processo de planejamento e gestão das cidades (VAINER, 2000, p.78). Tal estratégia seria considerada o resultado de "uma tentativa de influenciar não apenas investidores e turistas em potencial, mas toda uma opinião pública, formando uma imagem de cidade conforme os interesses e a

17 Jordi Borja e Manuel Castells, arquitetos catalãs, são dois dos maiores "porta-vozes" do planejamento estratégico. 
visão de mundo dos grupos dominantes" (SOUZA, 2006, p.303). Como coloca Souza (2006), o problema que reside no marketing urbano, seria, de maneira genérica, o mesmo que é atrelado à uma propaganda enganosa, uma vez que as qualidades consideradas negativas do produto seriam maquiadas, enquanto as qualidades positivas, exageradas. Para além da questão de qualidades/defeitos, a lógica usada para administrar uma cidade como mercadoria - a qual é pensada através do marketing -, como coloca Lefebvre, ignora o fato do espaço ser composto por um complexo sócio-espacial que agrega simultaneamente diferentes leituras e interpretações sobre o espaço e que comporta desejos diversos - tal como se entenderia como próprio à essência da cidade.

A fabricação de consensos em torno do crescimento a qualquer preço, como afirma Arantes, torna-se a peça-chave neste contexto, criando-se assim ideologias sobre o território, a comunidade e o entendimento sobre civismo, além de um senso comum econômico $^{18}$. O que se constrói para a cidade é uma suposta imagem de homogeneidade e um acordo sobre seu projeto de futuro.

Entre diversas estratégias para atingir o "sucesso", segundo Borja \& Castells (1996), estaria a "venda de imagem de cidade segura e/ou atrativa" (VAINER, 2002). Nesse contexto, o que passa a guiar o projeto de cidade seria a "boa imagem" que a mesma apresenta para seus investidores. Afinal, nestes cenários construídos como espetáculo - onde, como aponta Debord, "tudo o que era vivido diretamente tornouse uma representação" (DEBORD, 2015, p.13) -, os problemas sociais e a realidade cotidiana também são considerados, muitas vezes, como questões paisagísticas. Apesar de frisar em seu discurso a importância da construção de espaços "democráticos e justos" - colocado como outro requisito para o "sucesso" -, tal pensamento de cidade vem, ao contrário, construindo espaços ainda mais segregados que, ao focar no lucro e no entendimento da cidade exclusivamente como "máquina de produzir riqueza" (ARANTES, 2002), faz com que projetos para

18 Este pensamento de construção de cidade baseia-se, segundo Arantes, na definição de Harvey Molotch (1976) sobre cidade-máquina-de-crescimento. Tal autor teria inspirado Hall na formulação do termo "cidade-empreendimento". Para Molotch (1976), coalisões das elites centradas em propriedade imobiliária e profissionais de amplo arco de negócios conformariam as políticas urbanas para que possibilitassem a expansão da economia local e o aumento da (sua própria) riqueza. Neste contexto, assim como atualmente, a fabricação de consensos em torno do crescimento a qualquer preço seria fundamental. 
melhoria de condição de vida dos habitantes e de estruturas mais igualitárias se tornem secundários.

Assim como já vinha sendo construído na cidade industrial apresentada por Lefebvre (2006b), o espaço dissensual ${ }^{19}$, essencial para a produção de uma cidade que convive com as diferenças e pluralidades, torna-se enfraquecido. Na cidademercadoria concretiza-se a negação radical da cidade enquanto espaço político: nada mais restaria das características existentes na polis grega. No pensamento empresarial não há tempo para reflexões sobre valores, utopias. Espera-se o pragmatismo, o sentido prático.

Como construir política e intelectualmente as condições de legitimação de um projeto de encolhimento tão radical do espaço público, de subordinação do poder público às exigências do capital internacional e local? Talvez nada mais consistente (...) que a necessidade do consenso. Sem consenso não há qualquer possibilidade de estratégias vitoriosas. O plano estratégico supõe, exige, depende de que a cidade esteja unificada, toda, sem brechas, em torno ao projeto. (VAINER, 2000, p.91)

\section{4}

\section{A cidade como palco de disputa}

Cabe ressaltar, por outro lado, que mesmo com a imposição de um pensamento único, o espaço construído pelo homem para ser o seu mundo - entende-se, a cidade - não se resumirá unicamente ao que se estabelecer pelo plano estratégico e pelos consensos impostos. Como colocado anteriormente, segundo citação de Lefebvre (2006b), o humano "habita como poeta", seu cotidiano será construído através das apropriações, dos encontros, da festa, da dimensão lúdica da cidade (CARLOS, 2001, p.360). As cidades sempre terão características pautadas pelos diferentes modos de viver, pensar, assim como os de sentir: "O modo de vida urbano produz ideias, comportamentos, valores, conhecimentos, formas de lazer, e também cultura" (CARLOS, 2005, p.26), os quais serão diversos, mesmo com a cidade transformada em mercadoria e gerida como empresa.

Como defende Lefebvre, a multiplicidade existente de práticas no/do espaço urbano mostra-se como possibilidade alternativa para o desdobramento de novos espaços.

19 Como aponta Jacques Rancière (apud JACQUES, in: ROSA, 2011, p.162), os conflitos e dissensos caracterizam a vida pública, sendo os espaços públicos transformados em imagens do espetáculo, a negação do político. Os espaços destituídos de conflitos seriam espaços apolíticos. 
Segundo o autor, a possibilidade de "algo diferente" nos espaços sociais seria característica fundamental para suas trajetórias revolucionárias. E este "algo diferente" não viria necessariamente de projetos concretos e conscientes, mas sim do "que as pessoas fazem, sentem, percebem e terminam por articular à medida que procuram significados para sua vida cotidiana" (HARVEY, 2014, p.22) ${ }^{20}$.

Neste contexto, frente à diversidade inerente ao espaço urbano, a cidade se apresentará como palco de luta, espaço no qual se consolidarão disputas sobre o que este deve ser e através do qual outros tipos de "habitar" irão confrontar-se com o "habitat" construído/imposto. Através destes diferentes modos de se pensar a cidade, além das imagens consensuais que tentarão vendê-la para o mercado internacional, também serão construídas formas de ruptura que irão questionar o "vir-a-ser" hegemônico.

Segundo Lefebvre, a cidade

nunca foi projeção passiva do conjunto social preexistente. Ela sempre acrescentou a essa projeção um princípio próprio de aceleração, de dinamismo, de desequilíbrio permanente, de transgressão... A cidade foi e continuará sendo uma totalidade; algo mais que seus elementos estruturais e funcionais. Sob esse aspecto é uma presença que se oferece sem que o habitar o esgote. Ela reúne todos os níveis da realidade e da consciência, os grupos e suas estratégias, os subconjuntos ou sistemas sociais, a vida cotidiana e a festa. Comporta um grande número de funções as mais importantes, das quais os funcionalistas esquecem a função lúdica, o informativo. Engloba coações imperiosas e apropriações rigorosas do tempo e do espaço, da vida física e dos desejos... a cidade é produto do possível... a concepção desse possível se baseia não na análise do atual mas na crítica do atual, enquanto é ele rompido pela análise, pela ideologia e pela estratégia baseada no entendimento analítico e não na racionalidade dialética." (LEFEBVRE, 1969, p. 165-166, apud. CARLOS, 2001, p.360)

A cidade é resultado de diferentes dimensões da vida humana, da sociedade que a habita, a produz e, que assim se reproduz continuamente a partir dela. Como bem aponta Carlos (2001), a noção de cidade e seu contínuo processo de transformação irão contribuir para que se entenda o mundo moderno em sua dimensão teórica e prática:

A cidade passa por uma crise cujo sentido está em seu processo de reprodução (e não fora dele). Se não atentarmos para o significado da noção de reprodução e onde estão as condições de possibilidade de transformação da vida na cidade, não caminharemos no sentido de refletir sobre a crise teórica, na pesquisa que desdobra

20 Práticas estas que criariam o que Lefebvre chama de "espaços heterotópicos". 
e se limita ao plano do empírico, no fato de que muitos confundem a cidade, o objeto (produto e obra humana), com o sujeito.

A construção do humano envolve apropriações, encontros, reuniões, a festa; a construção da dimensão lúdica, que transcende o espaço privado, que se assenhoreia do espaço público (CARLOS, 2001, p.360).

Neste sentido, para pensarmos a cidade e discutirmos o seu sentido e finalidade, será necessário compreender as diferentes práticas e características do espaço urbano e considerar o ser humano como central em sua formação - e não mero coadjuvante, papel que lhe vem sendo conferido.

Compreender as diferentes forças e características que se formam no espaço urbano seria uma maneira não só de buscar a superação da homogeneidade imposta ao espaço, mas de se discutir a produção de uma cidade mais próxima ao que os habitantes pretendem para o seu mundo. Tal compreensão sobre o espaço não seria, porém, tarefa trivial.

\subsection{1}

\section{A produção do espaço}

Em “A produção do espaço" (2006a), Lefebvre defende que para prever o "possível e o futuro" do espaço urbano, é necessário compreendê-lo não apenas através das diversas "camadas" que o constrói, mas pela busca de sua gênese. Para o autor, em um contexto pautado pela lógica capitalista, torna-se complexo compreender o que realmente está contido no espaço, sendo necessário, assim, explicitar a forma como ele teria sido construído.

Cabe aqui repetir que, como coloca Lefebvre (2006a), o espaço urbano não é um simples palco onde se desenrola a vida cotidiana: a cidade é um "produto social", resultado da sociedade que nele habita, o produz e nele se reproduz, criando assim uma relação de coexistência. A sociedade e o espaço é que farão seu próprio arranjo espacial, de acordo com sua lógica societária, o que implica que o espaço urbano está em constante transformação.

O conceito de espaço social para Lefebvre está ligado diretamente à relação entre espaço e tempo, elementos fundamentais na teoria do autor. Como tais elementos são produzidos socialmente, só podem ser compreendidos através do contexto de 
uma sociedade específica. Assim, a análise do espaço deve considerar questões históricas de relação de poder e conflitos - o que demandaria analisar-se o espaço pela sua globalidade - que sejam relevantes em cada situação específica.

É importante destacar, porém, que tal análise para a compreensão do espaço não deve ser desenvolvida a partir de uma narrativa histórica, cronológica: o espaço é composto por diferentes dimensões, constituído simultaneamente pelo mental e o cultural, o social e o histórico, através dos quais reconstitui-se um processo complexo de descobertas, produção e criação, segundo a lógica da simultaneidade. Para Lefebvre, a produção do espaço social combinaria a realidade e o ideal, sendo ao mesmo tempo prático, simbólico e imaginário, provocando também simultaneamente - ordem e desordem. Seu pensamento desenvolve-se a partir dos seres humanos, de suas ideologias, sensibilidades, relações, atividades e práticas. O espaço contém, em si, relações sociais, e assim, é reproduzido por elas.

A ideia de produção, como aponta Carlos (2011), teria ao longo da obra de Lefebvre, uma dupla determinação: estaria atrelada, por um lado, à uma noção objetiva, ou seja, ligada a produção de objetos, produtos e mercadorias, assim como condição para reprodução da vida e, por outro lado, a um processo de subjetivação, no qual a produção do mundo da mercadoria estaria atrelada a sua linguagem e representação: "ao mesmo tempo em que o homem produz o mundo objetivo, (real e concreto), produz igualmente uma consciência, desejos, um mundo de determinações e possibilidades capaz de metamorfosear a realidade (...)" (CARLOS, 2011, p.56).

Neste sentido, para além da "produção" como bens materiais, o termo aborda também para a relação simbólica e de relações de poder construídas no espaço e responsáveis por sua constante (re)produção (SOUZA, 2013, p.42).

A cidade aparece como materialidade, produto do processo de trabalho, de sua divisão técnica, mas também de sua divisão social. É materialização da história dos homens, normatizada por ideologias; é forma de pensar, sentir, consumir; é modo de vida, de uma vida contraditória. (...) Se o processo de reprodução, por um lado, refere-se ao processo de realização e acumulação do capital, de outro refere-se ao desenvolvimento da vida humana em todas as suas dimensões e significados (CARLOS, 2005, p.26).

Para além do espaço material (espaço absoluto) e as relações sociais nele desenvolvidas, Lefebvre (2006a) destaca as representações sobre tais relações 
também como cruciais para a reprodução o espaço. Neste sentido, podemos dizer que produção do espaço para Lefebvre seria resultado do encontro entre dimensões dividas em três níveis: o que seria o "percebido", o "vivido", o "concebido". A tríade seria ligada, respectivamente, aos conceitos de "prática espacial", "representação do espaço" e "espaços de representação". Tais conceitos seriam a "chave" para a compreensão da teoria de Lefebvre (2006a), as quais devem ser consideradas como dimensões dialeticamente interconectadas.

Em outras palavras, as três dimensões seriam responsáveis por, dialeticamente, produzir continuamente o espaço urbano. Cabe aqui discorrer sobre cada uma. A dimensão da "prática espacial", referente ao espaço percebido, seria alusiva ao espaço da interação tátil, da experiência, das práticas sociais que acontecem em uma base material determinada (HARVEY, 2015). Esta dimensão seria relativa aos fluxos, transferências e interações físicas e materiais que ocorreriam no espaço e que garantiriam a produção e a reprodução social (HARVEY, 2004, p.201). É o que há de mais próximo à vida cotidiana, o espaço onde os habitantes desenvolveriam suas "competências como ser social situado num determinado tempo e lugar" (DELGADO, 2017). Segundo a definição de Lefebvre, a "prática espacial" seria aquela

\footnotetext{
"que engloba a produção e a reprodução, lugares especificados e conjuntos espaciais próprios a cada formação social, que assegura a continuidade numa relativa coesão. Essa coesão implica, no que concerne ao espaço social e à relação de cada membro de determinada sociedade com o seu espaço; ao mesmo tempo numa competência certa e uma performance. " (LEFEBVRE, 2006a, p.31)

"A prática espacial de uma sociedade secreta seu espaço; ela o põe e o supõe, numa interação dialética: ela o produz lenta e seguramente, dominando-o e dele se apropriando. Para a análise, a prática espacial de uma sociedade é descoberta decifrando seu espaço." (LEFEBVRE, 2006a, p.34)
}

Já a dimensão da "representação do espaço", relativa ao espaço concebido, referese aos signos, códigos, significações, conhecimentos que possibilitam abordar a "prática espacial". Tais representações serviriam como um esquema organizador ou um quadro de referência para a comunicação, que permite uma orientação (espacial) e, assim, ao mesmo tempo, co-determina a atividade do espaço (HARVEY, 2004). Seriam espaços concebidos pelas ciências, pela técnica e teorias filosóficas do espaço: uma "ideologia adornada com conhecimentos científicos e disfarçada através de linguagens que se apresentam como técnicas e especializadas, que a torna 
inquestionável” (DELGADO, 2017). Seria o espaço do poder, que se apresenta como "organização do espaço"; que se pretende como dominante sobre os demais espaços da tríade. Nas palavras de Lefebvre (2006a), as "representações do espaço" seriam definidas como:

ligadas às relações de produção, à 'ordem' que elas impõem e, desse modo, ligadas aos conhecimentos, aos signos, aos códigos, às relações 'frontais'." (LEFEBVRE, 2006a, p.31)

As representações do espaço, ou seja, o espaço concebido, aquele dos cientistas, dos planificadores, dos urbanistas, dos tecnocratas 'retalhados' e 'agenciadores', de certos artistas próximos da cientificidade, identificando o vivido e o percebido ao concebido (o que perpetua as sábias especulações sobre os Números: o número de ouro, os módulos e 'canons'). É o espaço dominante numa sociedade (um modo de reprodução). As concepções do espaço tenderiam (com algumas reservas sobre as quais será preciso retornar) para um sistema de signos verbais, portanto elaborados intelectualmente." (LEFEBVRE, 2006a, p.35)

Por outro lado, os espaços de representação - referente ao espaço vivido - seriam

alusivos a invenções mentais que criariam novos sentidos/possibilidades para práticas sociais: seriam também códigos, signos, assim como poderiam ser discursos espaciais, planos utópicos, paisagens imaginárias, ou até construções materiais como espaços simbólicos, pinturas, etc (HARVEY, 2004). Seria o “espaço vivido das sensações, da imaginação, das emoções e significados incorporados no modo como vivemos o dia a dia" (HARVEY, 2004, p.12). É o espaço dos habitantes, dos quais artistas, escritores, filósofos entre outros, o descrevem. Na definição de Lefebvre, "espaços de representação", seriam os que

apresentando (com ou sem código) simbolismos complexos, ligados aos lado clandestino e subterrâneo da vida social, mas também à arte, que eventualmente poder-se-ia definir não como código do espaço, mas como código dos espaços de representação." (LEFEBVRE, 2006a, p.31)

Os espaços de representação, ou seja, o espaço vivido através das imagens e símbolos que acompanham, portanto espaço dos 'habitantes', dos 'usadores', mas também de certos artistas e talvez dos que descrevem e acreditam somente descreverem os escritores, os filósofos. Trata-se do espaço dominado, portanto, submetido, que a imaginação tenta modificar e apropriar. De modo que esses espaços de representação tenderiam (feitas as mesmas reservas precedentes) para sistemas mais ou menos coerentes de símbolos e signos não verbais." (LEFEBVRE, 2006a, p.34) 
Nele, os espaços físicos seriam sobrepostos por sistemas simbólicos complexos e convertidos em moradas de imagens e imaginários (DELGADO, 2017). Como bem sintetiza Harvey (2015),

Henri Lefebvre, como Walter Benjamin, insiste que nós não vivemos como átomos materiais flutuando ao redor de um mundo material; nós temos igualmente imaginações, medos, emoções, psicologias, desejos e sonhos (BENJAMIN, 1999). Estes espaços de representação são uma parte integrante de nosso modo de viver no mundo. Podemos igualmente procurar representar a maneira com que este espaço é emocionalmente, afetivamente, mas também materialmente vivido através de imagens poéticas, composições fotográficas, reconstruções artísticas. (HARVEY, 2015, p.136)

É certo que nos espaços de representação é possível encontrar códigos construídos a partir da lógica dominante, porém Lefebvre enfatiza o "lado clandestino" da vida social que tal dimensão constrói. Como aponta Delgado (2017), sua definição estaria ligada ao "espaço qualitativo das submissões às representações dominantes do espaço, mas também onde se bebem e se inspiram as deserções e desobediências".

Ao abordar o espaço a partir das tríades dimensionais, Lefebvre traz a todo tempo a oposição entre o espaço vivido (do espaço de representação), caracterizado pelos sentidos sensoriais, e o espaço concebido (da representação do espaço), um espaço criado pelo planificador, o arquiteto, o tecnocrata. Lefebvre entende que as representações próprias dos habitantes (construídas a partir do espaço vivido) poderiam criar um contra-espaço, distinto àquele desenvolvido para o espaço hegemônico.

Neste contexto, os conflitos, lutas e contradições se tornariam inerentes ao espaço e seriam também de considerável importância para sua compreensão. Uma vez que a lógica capitalista oculta o que estaria contido no espaço ${ }^{21}$, seria preciso entender a reprodução espacial a partir de todas supracitadas dimensões, dialeticamente.

Segundo Carlos (2005),

21 Como aponta Delgado (2017): “Por detrás desse espaço concebido e representado não há outra coisa que a mera ideologia, no sentido marxista clássico, isto é como fantasma que recobre as relações sociais reais de produção, neste caso fazendo crer com frequência na neutralidade de valores abstratos universais, tornando-se um obstáculo para a revelação da sua autêntica natureza e, portanto, da sua futura transformação." 
(...) o espaço urbano se reproduz na contradição/luta. De um lado estão necessidades do processo de valorização do capital - enquanto condição geral de produção - em que o indivíduo se perde, cria-se o estranhamento, o distanciamento e o desencanto do mundo; a cidade dividida e vendida aos pedaços, espelha a segregação do habitante, expulsando-o da vida humana em todas as suas dimensões, enquanto retomada dos lugares, recriação de pontos de encontro, e da busca de identidade com o outro. É preciso decifrar os significados mais profundos do urbano, é preciso traduzir a vida urbana em sua realidade prático-sensível. O espaço urbano como produção social sai da prática, do modo de produção, das relações dominadas pelo capital, mas reage a eles. (CARLOS, 2005, p.92)

Considerando as questões colocadas até aqui, não só referentes à "essência" do "mundo" criado pelo ser humano, mas também às dimensões relativas à produção do espaço urbano, proponho abordar nos capítulos seguintes o cenário do Rio de Janeiro e discutir o campo de disputa por sua representação no período entre 2009 e 2016.

Proponho apontar elementos do "saber técnico" hegemônico que teriam contribuído para a construção da imagem-marca da cidade, mas por outro lado, trazer representações que disputam com ela o espaço da cidade, aquelas que seriam referentes ao espaço vivido, construídas por moradores da Favela Nova Holanda sobre o cotidiano vivido na escala local.

Pensar a cidade é refletir sobre o sentido da vida e como ela se realiza, significa pensar a plena dimensão do homem, o que revela a cidade como liberdade. Se é na vida cotidiana que se realiza a norma, ganha forma a segregação, é onde estão as possibilidades de apropriação do espaço. Portanto, a reflexão sobre o sentido da prática na cidade coloca como necessidade a consideração das possibilidades que aparecem ou existem na cidade para a vida (CARLOS, 2001, p.361). 


\section{3 \\ O Rio de Janeiro concebido: \\ a Cidade Maravilhosa como imagem-marca}

O capítulo tem como objetivo tratar das representações hegemônicas que se buscou construir para a cidade do Rio de Janeiro no período entre 2009 e 2016. Aqui, procuro traçar não só a representação pretendida para divulgar a cidade internacionalmente, como também investigar alguns dos caminhos utilizados para consolidá-la.

É possível dizer que, no período em questão, pretendeu-se que o Rio de Janeiro voltasse a ser "a vitrine do país" após décadas de crise e abandono. O projeto que se construía para a cidade parecia buscar inseri-la no mapa das metrópoles contemporâneas, como uma cidade da "rede global", descrita por Jacques (2011a) no capítulo anterior. Nesse sentido, a cidade passou a ser pensada através da "vocação" determinada por seu plano estratégico, o qual apontava que o espaço urbano tinha potencial para receber eventos globais de grande porte. Assim, através da reconstrução do imaginário ${ }^{22}$ da cidade, de megaprojetos e transformações urbanas, buscou-se consolidar a imagem-marca que atrairia investimentos e turistas de diferentes lugares à capital carioca.

Mas afinal, qual teria sido esta representação que se buscava construir? Antes de responder à pergunta - objetivo principal do capítulo -, busco contextualizar o momento vivido no período em questão. Pontuo questões que teriam culminado na decisão por um projeto de cidade que colocaria o Rio de Janeiro como palco de megaeventos globais. Em seguida, procuro compreender como foi traçada a

22 O imaginário não teria o potencial de "ativar a si mesmo" senão por uma instância externa. Ele comporia o universo de representações criadas pelos sujeitos sociais nas relações que formam as imagens criadas pela sociedade (LE GOFF, 1989 apud BARBOSA, 2000). Segundo Lefebvre (1983 apud BARBOSA, 2000), o imaginário designaria a relação da consciência (reflexiva/subjetiva) com o real, com outro lugar e com outro corpo através da mediação de imagens. Neste sentido, o possível, o virtual, o futuro, só seriam passíveis de representação através do imaginário. 
imagem-marca pretendida, apontando, simultaneamente, certos meios utilizados para consolidá-la.

Proponho demonstrar como o antigo imaginário da "Cidade Maravilhosa" não só passou a ser resgatado, como também foi acrescido por uma representação de um espaço urbano que estaria apto a inserir-se no contexto das cidades contemporâneas globais ${ }^{23}$. Para ilustrar esta construção, parto de três "frentes" que se apresentaram como representativas sobre a imagem que se pretendia consolidar: i) a concepção de um discurso e simbolismo sobre a cidade a partir de campanhas desenvolvidas por agências publicitárias em 2009 e 2011; ii) a busca pela chancela da UNESCO no reconhecimento da paisagem cultural da cidade como Patrimônio Mundial da Humanidade, iniciada em 2009 e conquistada em 2012; e iii) o uso da arquitetura e da renovação urbana na construção de um espaço que seguisse os parâmetros determinados para cidades pretendidas como globais, o qual exemplificaremos a partir do caso da "revitalização" da região portuária.

Em comum, as três "frentes" apontadas aqui não só teriam contribuído para construir a representação da cidade, como também buscariam idealizar o modo de "ser" do carioca a partir de referências da Zona Sul da cidade, das belezas naturais, de um espaço urbano existente entre "o mar e as montanhas". Por entender que as representações são tão importantes na produção do espaço quanto o espaço material e as relações sociais que nele ocorrem (Lefebvre, 2006a), proponho discutir a homogeneização imposta sobre a cidade a partir de algumas de suas representações. Neste contexto, abordo questões que apontarão o discurso da razão técnica e sua orientação espacial para o espaço urbano, assim como - e consequentemente - de que forma tais representações omitem espaços como os das favelas, repetindo assim, o discurso da favela como problema e de sua negação histórica como locais legítimos da cidade (PERLMAN, 1977; VALLADARES, 2005; GONÇALVES, 2013).

23 Representações estas, que buscariam mostrar como a cidade atendia a "requisitos" específicos, tais como ser uma cidade inovadora, sustentável e tecnológica 


\section{1 \\ O discurso construído: de "cidade em crise" a Cidade Olímpica}

Os apontamentos de Jacques (2011a) sobre o processo de espetacularização das cidades contemporâneas ${ }^{24}$, assim como as colocações sobre a cidade do pensamento único de Arantes et al (2009) - ambos citados no capítulo 2 -, indicam características vistas e vividas também no Rio de Janeiro no período de 2009 a 2016. Nesse sentido, os autores apontam para uma cidade que estaria sendo pautada pelo espetáculo, construída através do "urbanismo de marketing”, um projeto no qual o espaço da cidade seria entendido como mercadoria e gerido como empresa. No contexto em questão, a cidade carioca parecia igualar-se a tantas outras, nas quais valoriza-se a construção de novos museus e pontos turísticos para os visitantes, ao invés de se procurar entender e construir a cidade a partir dos usos e necessidades de seus próprios moradores.

Em realidade, a busca por fórmulas que conduzissem a cidade à competição em escala global teria sido iniciada anteriormente ao período aqui trabalhado. Já em 1993, o então prefeito Cesar Maia, convidou a renomada consultoria internacional liderada pelo arquiteto Jordi Borja ${ }^{25}$ para desenvolver o primeiro planejamento estratégico da cidade, intitulado "Rio sempre Rio" (MARICATO, 2001). Considerada uma iniciativa vanguarda no Hemisfério Sul, o planejamento estratégico teria se tornado o marco de uma gestão urbana empreendedorista, que guiaria a cidade até o ano de 2016.

Carlos Vainer (2002), ao analisar o planejamento em questão destaca não apenas o fato da cidade iniciar, a partir deste momento, a busca por apoio da iniciativa privada $^{26}$, como também frisa a construção dos consensos acerca do projeto de cidade. Como mencionado, sem tais consensos (na visão dos consultores) dificultar-

\footnotetext{
24 Como apontado no capítulo anterior, segundo a autora, diferentes processos como a turistificação, musealização, patrimonilização, etc., constituem tal dinâmica de criação de centros urbanos pautados pelo espetáculo em que se procura construir uma imagem de cidade de modo que a mesma possa, antes de mais nada, "pertencer à geopolítica das redes globalizadas de cidades turísticas, históricas ou culturais".

25 À época, consultorias internacionais, tais como a liderada por Jordi Borja, construíam planejamentos estratégicos inspirados na experiência de Barcelona - cidade-sede dos Jogos Olímpicos de 1992 que se tornou símbolo de modernização e sucesso por usar tal ferramenta.

26 A começar pelo financiamento da consultoria catalã, feita pela Associação Comercial do Rio de Janeiro (ACRJ) e pela Federação de Indústria do Estado do Rio de Janeiro (FIRJAN).
} 
se-ia o entendimento de que tais estratégias seriam "vitoriosas", tendo em vista que o discurso que se construía seria o que trata a cidade como uma unidade.

Através deste discurso, se legitimariam orientações e projetos de interesse de grupos dominantes da cidade, estando dentre eles, projetos de recuperação da imagem turística do Rio de Janeiro. A partir daí, é formulado um novo discurso sobre a cidade que preconizaria algumas diretrizes presentes até o ano de 2016, tais como o combate à desordem urbana, o controle do espaço público, a inserção do Rio de Janeiro no cenário de competição internacional entre as grandes metrópoles, a realização de parcerias entre setores público e privado, uma postura proativa da administração municipal em relação ao espaço urbano, entre outras (BARANDIER, 2006). Ademais, o Planejamento Estratégico "Rio Sempre Rio" já expressava a vocação esportiva da cidade, uma virtude para a cidade que acreditavam poder colocar o Rio de Janeiro na corrida por capitais, investimentos e eventos ${ }^{27}$.

O projeto de cidade que começava a se construir, tornaria o Rio de Janeiro palco dos maiores eventos mundiais nas décadas seguintes com os Jogos Pan Americanos (2007), os Jogos Militares Mundiais (2011), a conferência Rio+20 (2012), a Jornada Mundial da Juventude (2013), a Copa das Confederações (2013). Ao ser selecionada também para ser sede dos dois mais importantes eventos esportivos do mundo, a Copa do Mundo FIFA (2014) e os Jogos Olímpicos (2016), a cidade ganharia destaque no cenário internacional e afirmar-se-ia, novamente, como vitrine do país (GONÇALVES et al., 2012).

A candidatura da cidade para megaeventos como estes teria (como proposta de marketing urbano) a intensão de promover o orgulho dos habitantes por pertencerem a uma cidade com caráter global, a um lugar que atrairia investidores internacionais e interesse de diferentes partes do mundo. Após a experiência de Barcelona, a possibilidade de sediar Jogos Olímpicos e grandes eventos em geral se tornava um ingrediente indispensável da "fórmula de sucesso" (ARANTES, 2002). A busca por sediar os Jogos Olímpicos passou a ser pleiteada pela prefeitura (em diferentes gestões), que via o evento como porta de entrada para investimentos e como forma de inserir-se definitivamente no cenário de cidades turísticas globais.

27 Ver: http://www.caurj.gov.br/?p=17377 
A vitória na eleição para cidade-sede - após sucessivas derrotas para 2004 e 2012 - geraria entre os cariocas a sensação do chamado "mito do evento olímpico", que consiste na crença de que o evento será capaz de alavancar a economia urbana, e que enxerga o esporte como portador de uma mensagem de saúde, regeneração, alegria, vigor, pacificação e disciplina (MASCARENHAS, 2016) ${ }^{28}$.

O momento vivido pela cidade em tal contexto de escolha - o ano de 2009 - era o de euforia, não só motivado pela eleição da Cidade Olímpica, como também por outros três importantes fatores, importante destacar: a vitória eleitoral municipal de Eduardo Paes que, sob a legenda "Somando Forças" construía um ideário político consensual sobre a cidade ${ }^{29}$; a descoberta do Pré-Sal e, com ela, a expectativa de capital para investir em projetos; e o lançamento do projeto de segurança do Governo do Estado intitulado Unidade de Polícia Pacificadora (UPP), que após a redução dos índices de violência no primeiro ano de implementação, mostrava-se como uma solução para a sensação de insegurança na cidade (COUTO, 2016). O cenário de esperança sobre o futuro se completaria, assim, com o resultado do título de cidade-sede dos Jogos Olímpicos. Defendia-se que tal conquista levaria, finalmente, o Rio de Janeiro a superar a situação de crise que abatera a cidade durante tantos anos.

A consciência de crise, vale frisar, é destacada por Borja e Castells (1996) como um dos pontos cruciais para a transformação de uma cidade que se pretende como "bem-sucedida". Segundo os autores, mudanças locais - para a consequente elevação ao cenário global - dependeriam do reconhecimento por parte dos moradores dos problemas da cidade para, a partir de então, ser possível avaliar a construção de um consenso sobre mudanças.

Em todas as cidades o projeto de transformação urbana é a somatória de três fatores: a) a sensação de crise aguda pela conscientização da globalização da economia; b) a negociação entre os atores urbanos, públicos e privados, e a geração de liderança local (política e cívica); c) a vontade conjunta e o consenso público para que a cidade

28 Como aponta Mascarenhas (2016), tal "mito" vem sendo derrubado nos últimos anos, fato demonstrado através da análise da quantidade de cidades que pretendem ser candidatas para os Jogos Olímpicos. Ver: Mascarenhas, 2016.

29 A legenda "Somando Forças" representava a coalisão dos três níveis de governo, reunindo os chefes do executivo nacional (Luis Inácio Lula da Silva - PT), estadual (Sérgio Cabral - PMDB) e municipal. Após décadas de conflitos entre governantes das diferentes escalas, transmitia-se a mensagem de que o consenso entre os governantes permitiria a concretização de projetos que há décadas os administradores buscavam implementar. 
dê um salto adiante, tanto do ponto de vista físico como econômico, social e cultural (CASTELLS \& BORJA, 1996, p.156).

No caso do Rio de Janeiro, entendia-se que a crise havia sido iniciada na década de 1960, com a transferência da capital para Brasília, fato que teria acarretado o esvaziamento político e a falta de investimentos na cidade. Um outro fator apontado também como produtor da sensação de crise vivida na capital fluminense, seria o entendimento das favelas como um problema para a cidade (uma construção histórica, como veremos mais à frente) e a percepção social de que a crise no Rio de Janeiro seria, principalmente, causada pela violência. Como aponta Leite (2012) ao falar sobre a "metáfora da guerra" - que atravessaria o período entre 1990 e a década de 2000 (a qual o discurso levaria à uma forte demanda por ordem pública),

\begin{abstract}
A representação do Rio de Janeiro como "uma cidade em guerra" foi gestada a partir de uma série de episódios violentos (arrastões, assaltos, sequestros, tiroteios, "balas perdidas", chacinas, rebeliões em presídios e instituições de jovens infratores, paralisações do comércio, escolas e serviços públicos por ordens de bandidos, muitas vezes emitidas do interior de prisões de "alta segurança"), que produziram um forte sentimento de insegurança diante das crescentes ameaças à integridade física e patrimonial de seus habitantes. (LEITE, 2012, p.379)
\end{abstract}

Neste contexto, colocada a consciência de crise da cidade, defendia-se uma urgente solução para a desordem vivida: ao tornar-se uma cidade vitrine para os esportes através da conquista do título de Cidade Olímpica de 2016, os cariocas deveriam superar os anos de decadência e investir no projeto de modernização da cidade. O cenário colocado seria uma forma de criar um ambiente propício a soluções apresentadas como um "mal necessário", mas que seriam justificáveis por buscarem um futuro melhor para a cidade. A constituição de ideias de crise e os posteriores consensos público-privado sugeridos promoveriam no cidadão o sentimento de pertencimento ao projeto de evolução da cidade.

Sobre o "mito do evento olímpico" (MASCARENHAS, 2016) e a ideia da superação de crise, o discurso defendido pela Prefeitura do Rio de Janeiro no Planejamento Estratégico de 2013-2016 mostra-se representativo. No material falase sobre a importância dos jogos como oportunidade de "transformações fundamentais para a cidade e na vida das pessoas" (PREFEITURA DO RIO DE JANEIRO, 2012, p. 229) uma vez que, ao se tornar Cidade Olímpica, o Rio de Janeiro passaria a receber atenções e investimentos. No documento acrescenta-se ainda: 
Aprendemos com o exemplo de Barcelona que, ao sediar os Jogos Olímpicos, o poder público deve decidir se a cidade vai servir ao evento ou o evento vai servir à cidade. Optamos com toda a certeza pelo segundo caminho (...). Claro que parte dos nossos esforços também contribui para a realização de Jogos inesquecíveis. Para fazer a nossa cidade ser ainda mais admirada no mundo inteiro e atrair novos visitantes, investidores e grandes eventos internacionais. Mas os Jogos passam. E a nossa responsabilidade é garantir que os maiores benefícios possíveis fiquem para sempre aqui. Cidade Olímpica é construir um Rio mais justo, integrado e desenvolvido. (PREFEITURA DO RIO DE JANEIRO, 2012, p. 229)

O forte caráter publicitário, comum aos planejamentos estratégicos, é visto também neste plano elaborado em parceria com uma empresa global de consultoria estratégica, a McKinsey \& Company. Como muitos autores apontaram sobre o contexto de preparação dos jogos, o cenário que se construía na cidade era consideravelmente distinto do proposto pelo trecho destacado acima. Os Jogos Olímpicos, como em outras cidades e em diferentes momentos históricos, foram usados como justificativa para que transgressões aos direitos dos moradores fossem levadas adiante (FAULHABER \& AZEVEDO, 2015).

A crença de que o Rio de Janeiro deveria pertencer à rede de cidades turísticas internacionais justificaria não apenas intervenções urbanas espetaculares (e não prioritárias à cidade), como também o controle dos espaços que não estivessem "de acordo" com a imagem-marca pretendida, fosse através de projetos de segurança pública tal como a Unidade de Política Pacificadora (UPP), fosse através de remoções ${ }^{30}$.

Especificamente sobre as remoções, vale destacar que, entre 2009 e 2015, mais de vinte mil famílias haviam sido removidas de suas casas. Como descrevem Faulhaber e Azevedo (2015), as desapropriações e as remoções em si, estariam conectadas com a abertura de uma área da cidade como nova fronteira de expansão do mercado imobiliário: "coincidentemente ou não, os assentamentos que apresentavam o maior risco geotécnico e que também recebiam obras de

30 Para além das questões relativas à violência e presença de armamentos nas favelas, uma das críticas que se coloca ao projeto de pacificação é o fato de ser dirigido também aos moradores de tais áreas. Como aponta Leite (2012), "Os dispositivos de disciplinarização são muitos: discursos, regulamentos, medidas administrativas e atividade policial que reprimem o que é considerado não civilizado (como bailes funk, musica alta, encontros e festas nas ruas, etc.); assim como atividades filantrópicas que valorizam e estimulam as formas de sociabilidade consideradas aceitáveis (...). Nesses termos, reedita-se de certa maneira a proposta dos parques proletários para civilizar os moradores das favelas." (LEITE, 2012, p.384) 
infraestrutura eram exatamente aqueles que estavam nas zonas de influência dos Jogos Olímpicos e da Copa do Mundo" (FAULHABER \& AZEVEDO, 2015, p.16).

A expansão da estrutura interna das metrópoles, assim como na cidade industrial descrita por Lefebvre, é caracterizada por processos seletivos na definição do acesso ou permanência no núcleo, lidos tanto como projeção do processo de acumulação, como quanto ao modelo de representação da hierarquia social vigente na sociedade em questão. (ROLNIK, 2015).

A partir de tais questões, pretendo destacar que o processo conjuntural que a cidade passa para receber os Jogos Olímpicos - assim como os outros grandes eventos não seria relacionado apenas a tal evento, mas sim a um processo estrutural que corresponde à abertura de fronteiras do próprio mercado, onde a "despossessão" dos ativos territoriais dos mais pobres torna-se parte da acumulação do capital em novas bases (ROLNIK in: FAULHABER \& AZEVEDO, 2015). Ser palco dos Jogos Olímpicos ou de outros megaeventos esportivos seria apenas um momento desta lógica que age sobre o espaço. Estaríamos, na realidade - como destacado anteriormente -, frente a um padrão de governança urbana empreendedorista e de uma nova rodada de mercantilização das cidades (GONÇALVES et al, 2012); de uma política que se pauta em maximizar os lucros ao invés de orientar-se pela satisfação de melhores condições de vida dos habitantes locais.

A frase "Cidade Olímpica é construir um Rio mais justo, integrado e desenvolvido" (PREFEITURA DO RIO DE JANEIRO, 2012, p. 229), acima destacada, mostravase como mais uma estratégia de marketing desenvolvida para o consenso que se propunha construir em torno do projeto pretendido para a cidade. A representação construída - não só a partir dos discursos contidos nos documentos da prefeitura, como por intervenções urbanas e outras ações, como veremos a seguir - manteria a lógica excludente e fragmentadora para espaços que não condiziam com a imagem pretendida para o Rio de Janeiro.

No período em questão, apesar do surgimento de diferentes movimentos de resistência que lutavam contra as violações de direitos do período, o que mais parecia sobressair para parcela da população era que a cidade poderia finalmente aproximar-se da "rede global de cidades", citada por Jacques (2004). O “orgulho de 
ser carioca" parecia estar de volta à ordem do dia. E as representações construídas para vender a cidade, certamente teriam influência sobre tal sentimento.

\section{2}

As representações do espaço concebidas para a capital carioca

As representações criadas para a cidade durante o período de 2009 a 2016 eram próprias da definição de espaço concebido, apontada por Lefebvre (2006a): tal construção impunha uma "ordem" ligada "aos conhecimentos, aos signos e aos códigos", característica de "cientistas e planificadores", que serviriam - tal como apontado no capítulo 2 - como um esquema ou um "quadro organizador" que orienta e co-determina a atividade do espaço.

Tal representação teria como base a antiga imagem sobre o Rio de Janeiro, vastamente difundida: ela seria pautada a partir da ideia da "Cidade Maravilhosa", aquela que teria o cotidiano entre o mar e as montanhas; onde a natureza, permanentemente presente, faria de seus moradores pessoas alegres, espontâneas e sempre dispostas a festejar a beleza da vida. A cidade onde a rotina seria descontraída, na qual seus habitantes seriam ora atléticos, ora boêmios, mas que, independente do perfil, seriam afeitos à vida ao ar livre. O local que serviria de inspiração a tantos artistas, onde seu cenário seria cantado em versos apaixonados, servindo também como poesia para os olhos de tantos pintores, cineastas e escritores. A cidade que seria o "coração do Brasil", como diria a famosa marchinha, a qual "batizaria", definitivamente, o Rio de Janeiro com o apelido de "Cidade Maravilhosa". De forma sucinta, uma capital feita para ser admirada, que ofereceria uma experiência única aos turistas e qualidade de vida para seus moradores.

Os elementos construídos para compor o imaginário social de tal representação teriam tido, segundo Barbosa (2012a), marco inaugural no início do século XX quando as reformas do prefeito Pereira Passos buscaram construir uma nova capital para o Brasil. O modelo urbano proposto para a cidade procurava reconstruí-la e embelezá-la para que pudesse simbolizar a importância do país entre as nações tidas como civilizadas e progressistas. Como justificativa para as intervenções, falava-se sobre garantia de salubridade, investimento em beleza, aumento de funcionalidade, 
desafogo de áreas congestionadas, compatibilização com novas atividades econômicas. Porém, como aponta Carlos Nelson Ferreira dos Santos (1988, p.40), "por trás de tudo, a grande razão escondida: desejo de um espaço bem arrumado que seja, ele mesmo, um discurso de ordem. Pessoas, atividades e usos devem ser classificados e discriminados nos devidos lugares. As misturas incomodam”.

Naquele momento, criava-se uma nova representação para a cidade do Rio de Janeiro. E, através de tal representação, a heterogeneidade existente no espaço passaria a ser suprimida: formas de vida não condizentes com o modelo profetizado pela imagem da cidade, não teriam o direito de habitá-la. Neste contexto, anunciouse o fim dos cortiços, lugares considerados insalubres que poderiam prejudicar a higiene e saúde pública de toda a capital fluminense. Sem outras alternativas de moradia - a não ser insuficientes conjuntos habitacionais construídos longe dos centros urbanos - as favelas passaram a serem vista como possibilidade de habitação na cidade para a população que se via excluída do plano de urbanização (ABREU, 1997).

Nos anos decorrentes à gestão de Pereira Passos, crescem as favelas existentes e surgem muitas outras. Os preconceitos e estigmas destinados aos cortiços passariam a ser, assim, endereçados a elas. Segundo Barbosa (2012a), em artigo publicado na Revista Careta em 4 de dezembro de 1909 - chamado "O Rio desconhecido" -, inaugurava-se uma das primeiras campanhas contra as favelas, consideradas como "os estranhos bairros". A imprensa da época, ao legitimar o projeto de espaço civilizado, ordenado e disciplinado da Cidade Maravilhosa em diversas reportagens e crônicas, fazia das favelas "um espelho invertido da civilização" (ZALUAR, 1998).

Desde que Pereira Passos destruiu os cortiços da Avenida Central, a ideia de "favela" passou a ser vinculada ao "dogma" de ser o lócus da pobreza (VALLADARES, 2005), espaço do crime e da "vadiagem". Tanto entre setores conservadores quanto progressistas da cidade foi-se consolidando a premissa de que as favelas seriam espaços de carência, precariedade, que se encontraria no limite da civilidade, de condições de humanidade (SOUZA, 2010). Tal como pontuado através do "mito da marginalidade" (PERLMAN, 1977), os pobres urbanos seriam estereotipados como a "classe perigosa", dos "vagabundos 
indolentes e preguiçosos", os "marginais". Aqueles que seriam o oposto das classes médias, um entendimento que orientaria, assim, ações da sociedade e do Estado sobre os espaços de favelas e seus moradores. A favela seria, desde seu surgimento, colocada como "problema social" a ser solucionado, ao invés de encarado como uma realidade urbana surgida a partir da busca pela sobrevivência frente às ausências infraestruturais da cidade, como alternativa para moradia das camadas populares (VALLADARES, 2005).

Ao negar as favelas como espaços integrantes da cidade, construía-se, simultaneamente, uma imagem do Rio de Janeiro que se resumiria à zona sul da cidade conhecida como "formal". Os morros, planícies, manguezais de rios e lagoas habitados pelas comunidades populares teriam historicamente significados muito distintos dos endereçados à cidade maravilhosa: seriam a paisagem a ser negada, espaços que agrediriam o culto à ideia do maravilhoso (BARBOSA, 2012a).

Pode-se dizer que a imagem construída sobre a cidade não só foi usada muitas vezes como aparato ideológico para afastamento e destruição de modos de vida não condizentes com seus valores, como também, ainda hoje, contribui para a negação do que foge do padrão estético e social do considerado "civilizado". E, da mesma forma que o "mito da marginalidade" ainda se mantém, a representação da cidade através das características naturais e situação geográfica também fundamenta a imagem construída como símbolo da cidade.

\subsection{1}

\section{A cidade desenhada nos cases publicitários}

A construção do imaginário da Cidade Maravilhosa no contexto atual pode ser vista através de diferentes representações. Um dos exemplos que proponho trazer, referese à produção desenvolvida em materiais publicitários e promocionais, encomendados pelo Governo do Estado e a Prefeitura da Cidade. Discuto tal questão através de dois casos nos quais a representação construída sobre o espaço urbano carioca mostra-se emblemática em relação às questões pontuadas até aqui.

O primeiro caso trata de dois vídeos que seriam parte da campanha de candidatura da cidade para sediar os Jogos Olímpicos. Ambos os materiais, produzidos em 2009 
pelo cineasta Fernando Meirelles, tinham como objetivo apresentar a cidade internacionalmente.

Em um deles, o qual seria considerado o material audiovisual "oficial" da candidatura por ter sido apresentado ao Comitê Olímpico Internacional (COI), apresenta-se os primeiros esboços das instalações para os Jogos Olímpicos através de representações tridimensionais da cidade. Já o segundo, mais curto, parecia pautar-se no intuito de representar o estilo de vida do carioca e o "espírito" do Rio de Janeiro. Ambos seriam referências literais à famosa "Cidade Maravilhosa" e contribuiriam, consequentemente, para a construção do imaginário da cidade a partir de tal representação.

Consideremos, primeiramente, o material tido como "oficial" de cerca de cinco minutos, apresentado ao COI na cerimônia de candidatura ${ }^{31}$. O que mais nos interessa aqui são os segundos iniciais do vídeo, no qual as "primeiras impressões" sobre a cidade são ilustradas. Através de imagens, o vídeo demonstra o ideal de cidade construído para vender o Rio de Janeiro ao evento: durante os dezesseis segundos iniciais mostra-se praias, o morro Dois Irmãos, o Arpoador, montanhas, verde por toda parte, pessoas correndo no aterro do Flamengo, conversando e cantando à beira mar, além de uma vista aérea de Ipanema. Mostra também os Arcos da Lapa e o Maracanã, além de uma cena dentro de um botequim. Como objetivo principal, o vídeo expõe as quatro áreas onde ocorrerão as competições, pontuandose também as principais características referentes a cada uma.

$31 \mathrm{https}: / /$ www.youtube.com/watch?v=yMLzB1fsSTc 


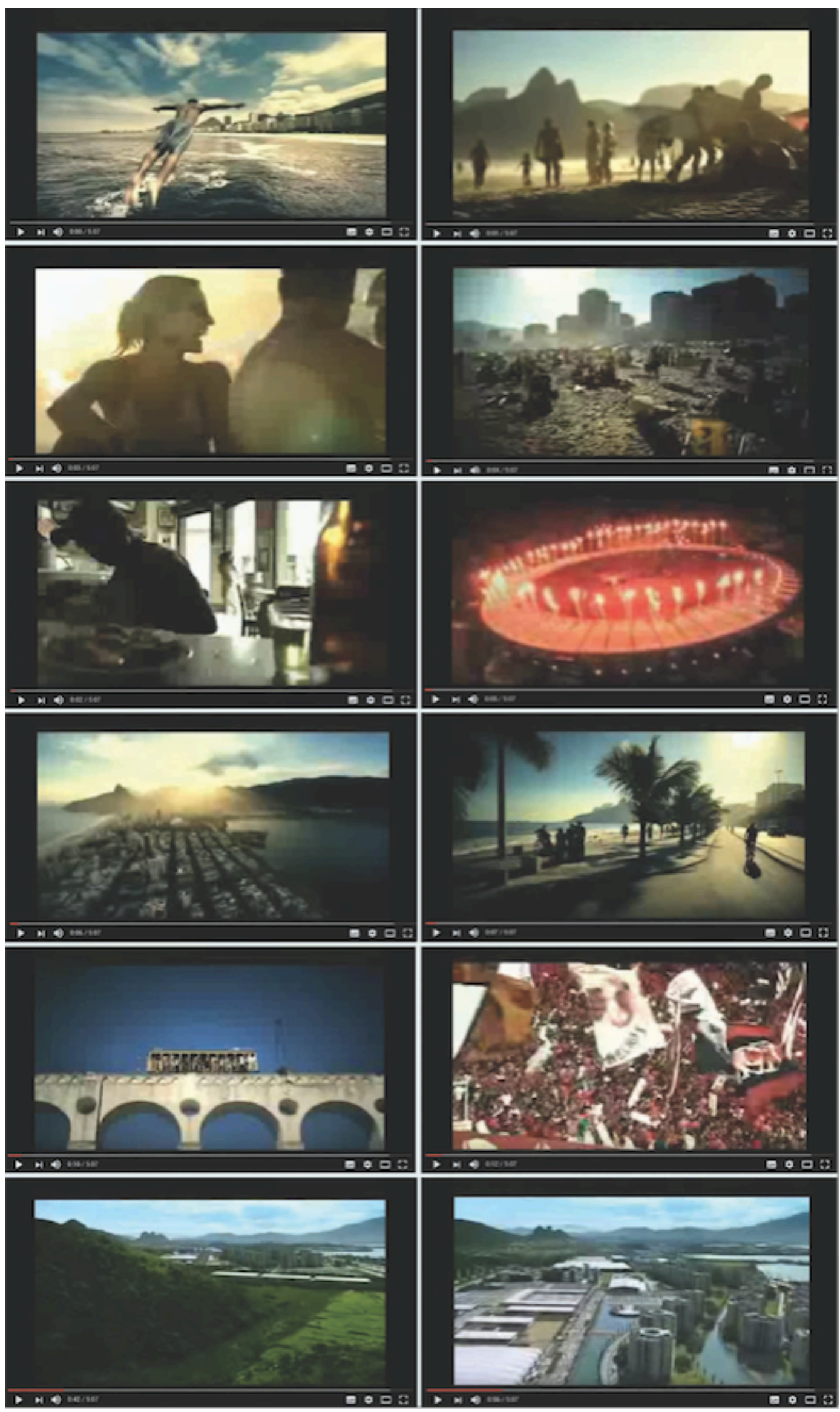

Figura 1 - Imagens iniciais do vídeo apresentado ao COI, em 2009. Frames selecionados pela autora. Fonte: https://www.youtube.com/watch?v=nTK90nJbtwQ 
Como bem observa o jornalista Juca Kfouri ${ }^{32}$ na época, ao longo de toda a edição, não se vê nenhuma favela na cidade - apesar de, segundo o Censo 2000 do IBGE (BARBOSA, 2012a), a população carioca residente em favelas representar 18,7\% de seu total. A negação das favelas como espaços legítimos da cidade se coloca, novamente, através do vídeo em questão. Constrói-se, a partir das cenas apresentadas, a imagem da "Cidade Maravilhosa", aquela que, massivamente reproduzida pela literatura, cinema, imprensa, música e propagandas durante séculos, ditaria um único modo de ser e viver do carioca, pautando assim o "'deverser' da cidade" (BARBOSA, 2012a).

O contexto do vídeo produzido parece demonstrar que as favelas não poderiam ser percebidas pelos juris do comitê. Para além da escolha de ângulos no vídeo onde as favelas da cidade não ficariam em evidência, é curioso notar como na animação tridimensional produzida para simular as intervenções do futuro Parque Olímpico da Barra da Tijuca (no minuto 1:28), a Vila Autódromo - a qual sofreria processo de remoção a partir de 2014 - já não existia na simulação de 2009. O local onde, no ano da divulgação do vídeo, era habitado por cerca de seiscentas famílias, aparece na imagem como uma área tomada por vegetação, sem sinais de moradias.

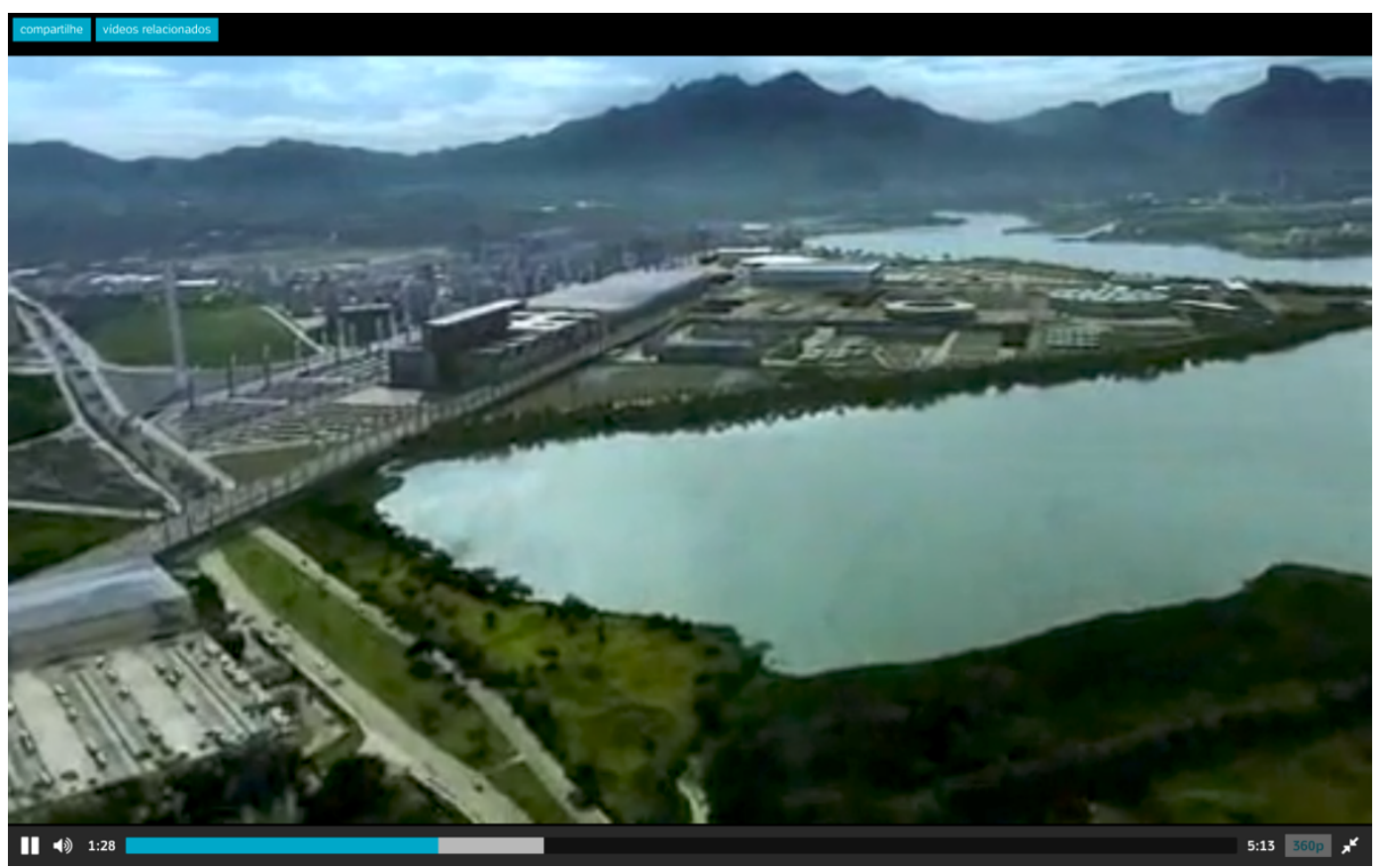

Figura 2 - Frame do vídeo apresentado ao COI com simulação do Parque Olímpico da Barra da Tijuca. Fonte: https://www.youtube.com/watch?v=nTK90nJbtwQ

32 Reportagem "Viva! Não tem mais favelas no Rio!!!”, de abril de 2009, disponível online no endereço virtual: http://blogdojuca.uol.com.br/2009/04/viva-nao-tem-mais-favelas-no-rio/ 
O segundo vídeo ${ }^{33}$, de cerca de dois minutos e vinte segundos, parece ter como objetivo mostrar a "essência" da cidade, falar sobre seu cotidiano. Apesar de também ser vinculado aos Jogos Olímpicos, este material não apresenta especificações sobre os locais dos jogos ou outras informações sobre a produção do evento. Ao longo das imagens, a marcha de carnaval "Cidade Maravilhosa" é usada como trilha sonora para ilustrar um olhar sobre quem são os habitantes do espaço e como o dia-a-dia local se desenrola. A representação da "Cidade Maravilhosa" também é reproduzida através das imagens: o vídeo mostra uma cidade de céu azul, de belezas naturais exuberantes, onde se praticam diferentes modalidades de esporte ao ar livre. Na cidade representada, pessoas atléticas compartilham o espaço com trabalhadores que realizam suas atividades com grande alegria, cantando marchinhas de carnaval enquanto realizam suas funções profissionais.

$33 \mathrm{https}: / / \mathrm{www} \cdot$ youtube.com/watch?v=_AW_isJfiVA 


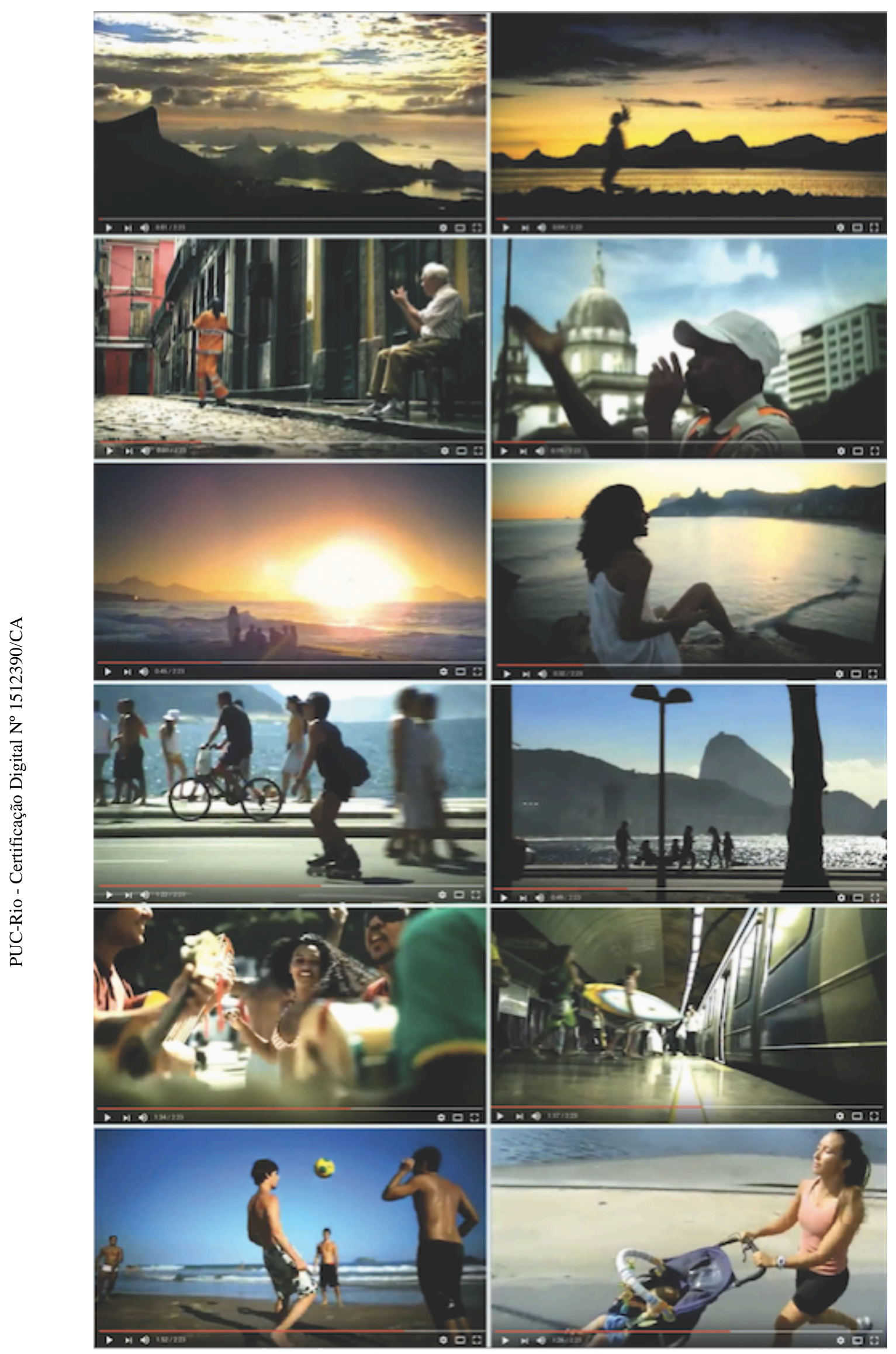

Figura 3 - Imagens de vídeo produzido na ocasião da candidatura da cidade para sediar os Jogos Olímpicos, em 2009. Frames selecionados pela autora. Fonte: https://www.youtube.com/watch?v=_AW_isJfiVA 
Com o intuito de divulgar a cidade internacionalmente, o vídeo reproduz, mais uma vez, o modo de vida da Zona Sul do Rio de Janeiro como sendo o legítimo ao cidadão carioca: em $80 \%$ do tempo do vídeo (1minuto e 49 segundos do tempo total) vemos paisagens das praias de Ipanema e Copacabana, a "altinha" na beira do mar, surfistas loiros que entram no metrô com suas pranchas, uma roda de violão no pôr do sol de Ipanema. A jovem mãe atlética que corre na beira da Lagoa Rodrigo de Freitas, a menina que canta na Pedra do Arpoador, crianças no Parque Lage. Ademais, pode-se dizer que, em sua maioria, as pessoas que exercem atividades de lazer no vídeo são brancas e o Rio de Janeiro representado para o mundo resumese, majoritariamente, ao eixo litorâneo da Zona Sul da cidade. Há, sim, algumas incursões nas quais é possível ver outras regiões do Rio de Janeiro. Nelas, que respondem aos outros $20 \%$ do tempo do vídeo, mostra-se cenas no centro da cidade $^{34}$, de um desfile de Escola de Samba, e no Maracanã. Importante salientar que ao longo de tal sequência de imagens, favelas também não são mostradas.

Ao final do vídeo, porém, uma imagem aparece quando a marchinha da trilha sonora já terminara. A sequência de seis segundos (Figura 4) é filmada do alto de um morro, de onde vemos a paisagem de uma praia e montanhas ao fundo - geografia que caracterizaria a cidade, segundo a representação. Ao longo da parte inferior da imagem, somente homens, em sua maioria negros, que parecem tocar instrumentos de percussão, comuns a Escolas de Samba e a outros ritmos musicais da cultura afro-brasileira. Todos vestem roupas brancas e muitos seguram velas acessas. Tais elementos, por possuírem forte simbolismo sobre paz, parecem sugerir o imaginário de uma cidade "pacificada", onde se viveria um "acordo" sobre a nãoviolência; de uma cidade que se "rende" à beleza de sua paisagem e opta pela paz.

34 Avenida Presidente Vargas com a Igreja da Candelária ao fundo, o que parece querer demonstrar aspectos urbanísticos da cidade; a área da rua do Ouvidor, o qual dá um ar histórico e bucólico ao espaço urbano; e nos Arcos da Lapa. 


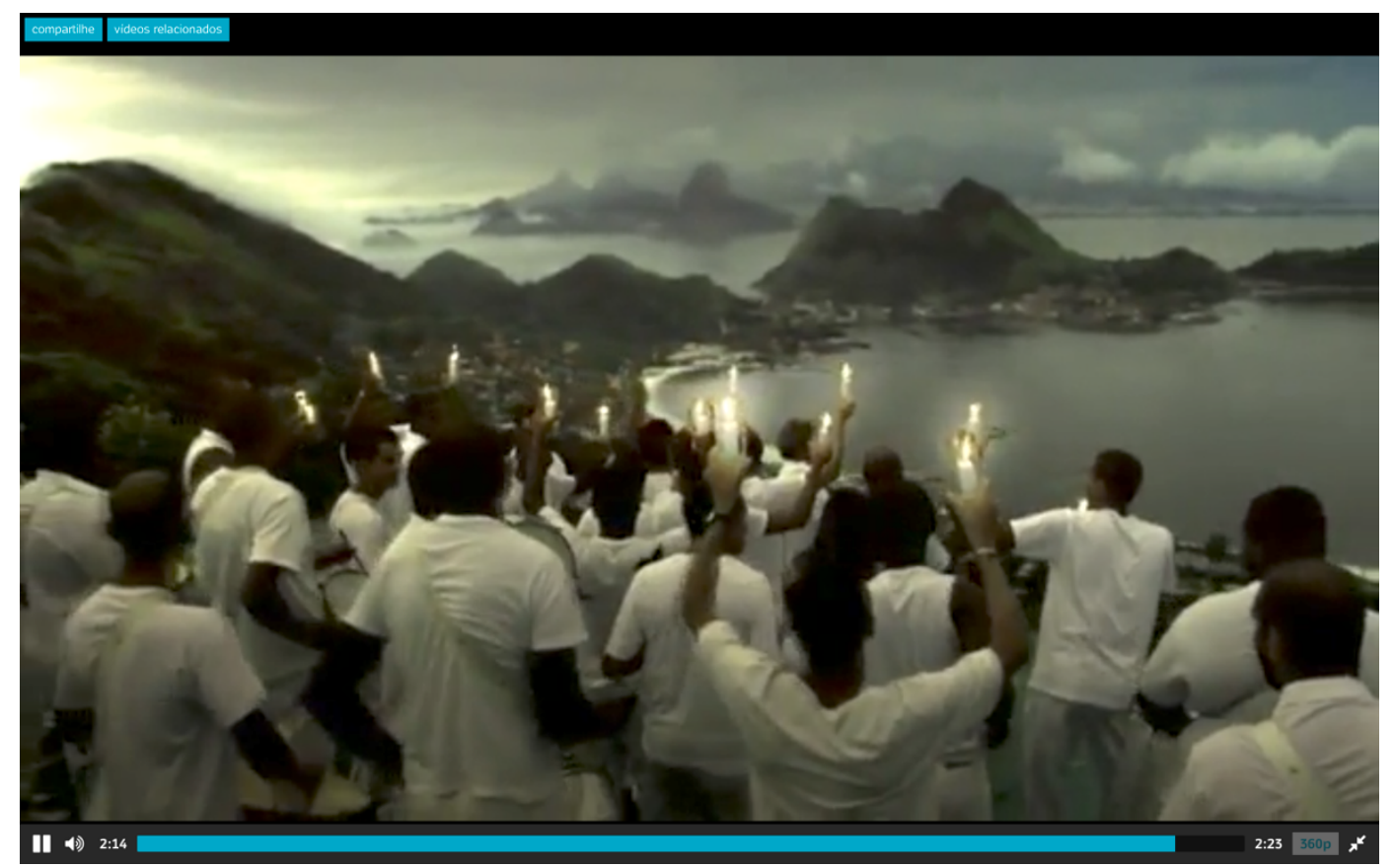

Figura 4 - fonte: Fonte: https://www.youtube.com/watch?v=_AW_isJfiVA

Ambos os vídeos, de 2009, parecem buscar construir uma imagem para a cidade que, de forma assertiva, apresentasse o Rio de Janeiro tal qual sugeriria o plano estratégico e suas "fórmulas de sucesso". Um lugar atraente, onde os habitantes sentiriam orgulho de viver, sem sinais de elementos que poderiam remeter a pobreza e desigualdade.

Além dos vídeos acima, a promoção da cidade para a ocasião da candidatura para sediar os jogos olímpicos teria contado também com “estratégias de gestão de imagem" desenvolvidas pela Agência Prole - a qual teria entre seus clientes o Governo do Estado e a Prefeitura da Cidade. Ela seria a responsável pela "construção" da imagem do Rio de Janeiro no período em questão.

Enquanto o plano estratégico da McKinsey \& Company - também de cunho tipicamente publicitário - procura difundir a ideia de que "Cidade Olímpica é construir um Rio mais justo, integrado e desenvolvido" (tal como vimos no início do capítulo), a apresentação da Agência Prole é "direta" sobre o propósito de seu material e a função dos Jogos Olímpicos para a cidade, quando apresenta o case “Cidade Olímpica” em seu portfólio virtual ${ }^{35}$. Segundo o conteúdo divulgado para

35 Em seu site, apresentam um vídeo no qual descrevem o desenvolvimento do case, que chamam de "Cidade Olímpica": http://www.prole.com.br/cases/?lng=pt\#2 
explicar o que teria produzido desde antes da candidatura até o ano de 2012, apontam que:

(...) Desenvolvemos o discurso da candidatura. Criamos o conceito de Cidade Olímpica. Uma forma de explicar as transformações pela cidade, mostrar a dimensão do legado das obras. Cidade Olímpica não é apenas o lugar de sediar os Jogos de 2016. É uma campanha bem-sucedida de divulgação do Brasil no exterior. Campanha que chega primeiro para todos os brasileiros, é claro. De várias maneiras. Mídias sociais. Mídias impressas. Mídias eletrônicas. Até em forma de música. ${ }^{36}$

Se, Cidade Olímpica "é uma campanha bem-sucedida de divulgação do Brasil no exterior", ao menos no momento da candidatura do Rio de Janeiro para cidade-sede, enquanto a cidade ainda não fosse contemplada com tal título, parecia acharem prudente que sua representação não fosse vinculada a espaços como os de favelas ${ }^{37}$. Afinal, segundo a lógica proposta por Borja e Castells, uma cidade com questões como a pobreza - as quais tornariam-se questões visuais, segundo Vainer (2001) , não se mostraria "atraente" para o mundo.

A mesma agência que desenvolveria tais "estratégias de gestão de imagem" para a cidade na ocasião, seria responsável também pela campanha publicitária desenvolvida para o Governo do Estado do Rio de Janeiro, divulgada no ano de 2011. Sobre o material, vale destacar dois pontos principais. O primeiro, sobre o caráter das imagens utilizadas que, novamente, adotam majoritariamente referências da Zona Sul da capital fluminense. Tal questão é ainda mais marcante uma vez que a campanha teria o objetivo de abranger todo o Estado do Rio de Janeiro $^{38}$. O segundo ponto que vale destaque, diz respeito ao caráter da linguagem

36 Fonte: http://www.prole.com.br/cases/?lng=pt $\# 2$

37 Cabe pontuar que os materiais desenvolvidos para o contexto de divulgação sobre os Jogos Olímpicos após a vitória na eleição para cidade-sede trazem representações que incluem favelas e moradores de favelas no material. Igualmente, vale destacar que as favelas e diferentes tipos de manifestações culturais de seus espaços, tal como o passinho, o rap e o pagode tiveram grande destaque durante o evento de abertura das Olimpíadas, no Maracanã.

38 Entre as imagens vinculadas, via-se favelas, as quais viriam ligadas a palavra "paz" ou à noção de devolução do espaço ao cidadão. A implementação das Unidades de Polícia Pacificadora provavelmente seria uma justificativa para a utilização das imagens ligadas a tais elementos. Uma outra possível influência poderia ser também o "público alvo" da campanha, que dirigia-se aos próprios cariocas. 
utilizada e do pensamento desenvolvido por sua "estratégia" de marketing, os quais partiria do conceito "RJ, Marca Registrada do Brasil".

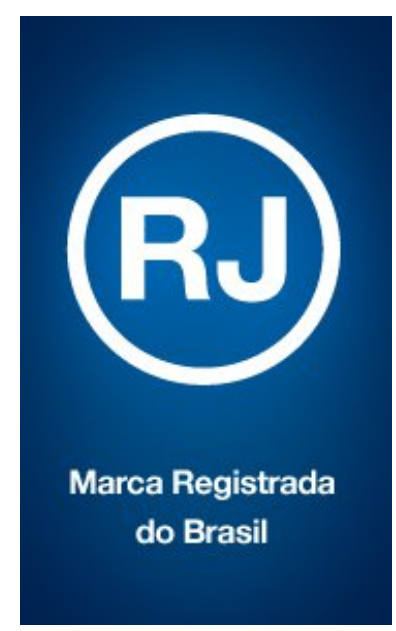

Figura 5 - Logotipo e conceito usados na campanha desenvolvida para o Governo do Estado, 2011.

O termo utilizado "Marca Registrada", remete novamente à questão da cidade como "vitrine" do país. Para além do sentido de cidade-símbolo do Brasil, a palavra apresenta também o Rio de Janeiro como uma mercadoria, o qual teria, inclusive, índices de ser patenteável.

No site da agência, através do material de divulgação sobre o case desenvolvido ${ }^{39}$ (um vídeo de um minuto e cinquenta e seis segundos), é possível identificar o olhar publicitário que passaria a guiar a representação da cidade. Ao falarem sobre o processo do projeto e as etapas de execução da estratégia desenvolvida, nota-se como já não haveria distinção alguma entre a construção de um pensamento empresarial e um pensamento para abordar o espaço urbano. E, mais do que uma "mera" identidade visual ou "apenas" mais uma campanha publicitária, a proposta buscava criar uma estratégia de branding ${ }^{40}$ para o estado fluminense, a "tendência atual" no mundo do marketing. Em outras palavras, o Rio de Janeiro seria pensado através das mesmas estratégias de mercado que produtos como a Coca-Cola ou empresas como a Apple utilizam atualmente. Com isso, a representação da cidade

39 http://www.prole.com.br/cases/?lng=pt\#1

40 Neumeier (2003) traça uma interessante definição das estratégias de abordagem do marketing ao longo do século que sintetiza qual seria a ênfase do branding: em 1900, o marketing focaria nos atributos dos produtos e na pergunta "o que é isso". De 1925 até a década de 1950, o foco estaria nos benefícios "o que isso faz". De 1950 ao ano 2000, seria voltado para a experiência do usuário, baseando-se na pergunta “o que você irá sentir". Já a partir de 2000 ao contexto atual, no qual o campo do branding se insere, procura tratar da questão da identificação do usuário a partir do produto: a estratégia, assim, se pautaria em definir, a partir do produto, "quem é você". A crítica de Debord (1996), neste contexto, se mostra cada vez mais atual. 
construída na ocasião seria pautada a partir de termos como "valores da marca" e "reputação da marca", os quais seriam definidos no projeto desenvolvido para o Estado do Rio de Janeiro como "beleza”, “energia”, "paixão”, “inovação”, “paz”, "alegria" (Figura 6).
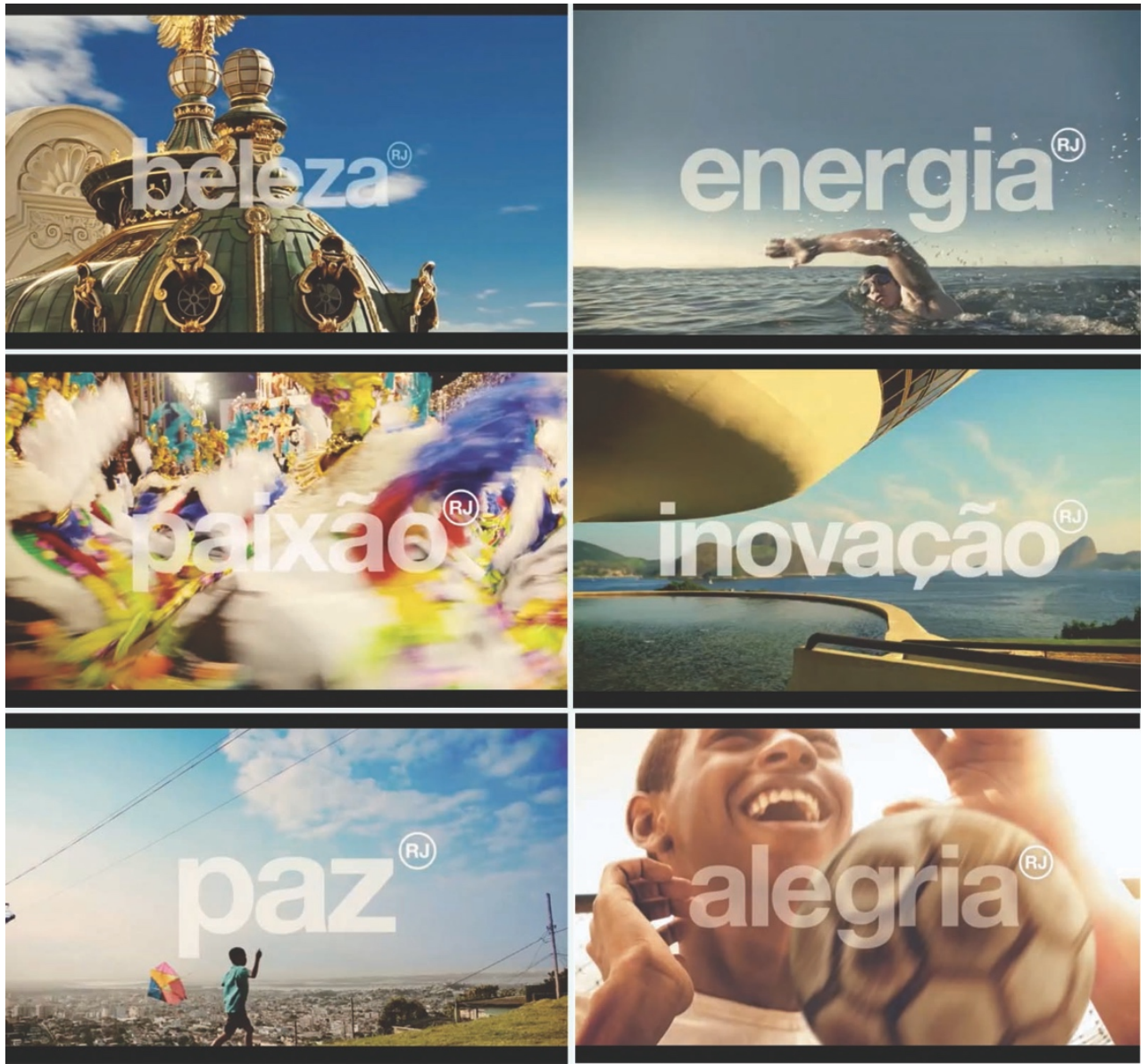

Figura 6 - Os seis "valores" do Rio de Janeiro, segundo a campanha. Frames do vídeo da Prole sobre o projeto, selecionados pela autora. Fonte: http://www.prole.com.br/cases/?lng=pt\#1

Ainda sobre o vídeo do case, alguns dos trechos apontam para indicações próprias dos planejamentos estratégicos, tal como reforçar o envolvimento do habitante através do "patriotismo cívico" destacado por Arantes (2000), ou seja, do orgulho de se viver na cidade do Rio de Janeiro. O material descreve que: "Para melhorar a autoestima do povo do Rio, reforçamos as marcas registradas de quem nasceu e de quem vive aqui" ${ }^{41}$. O site da Imprensa Oficial do Estado do Rio de Janeiro, ao abordar a campanha, também aponta para o consenso sobre a representação da 
cidade que o material propunha atingir: "O objetivo é organizar a sociedade fluminense em torno do novo momento que o Estado vivencia"42.

Através do projeto, o Rio de Janeiro, não só passaria a ser uma marca, mas também um produto em si, que poderia associar-se a outras marcas para poder, assim, fortalecer seu potencial ${ }^{43}$ de brand, segundo a agência de publicidade. Como apontado, ainda no vídeo: "Depois de consolidar a marca, era a hora de trabalhar parcerias e co-branding, através de produtos com máxima qualidade e identificação com o Rio - já são, atualmente, sessenta e três parceiros"44. O reconhecimento da "marca" RJ contribuiria, segundo a campanha, para promover o orgulho de "ser carioca".

A exemplo de grandes capitais internacionais, tal como Nova Iorque e Amsterdã, o Rio de Janeiro passaria a adotar a mesma estratégia de divulgação do espaço urbano no cenário internacional, com o intuito de "apresentar" a história da cidade e os atributos locais específicos em um contexto de competitividade global. A "tendência" vivida no ano de 2011 seria seguir o chamado city branding ${ }^{45}$ e, ao adotá-lo, o Rio de Janeiro parecia querer estar alinhado às fórmulas de sucesso. Ademais, ainda que a estratégia tenha sido proposta para todo o estado fluminense, a representação que se construiria na ocasião seria, novamente, da "Cidade Maravilhosa", de um estado habitado por "cariocas da gema".

\section{2 .2}

\section{A cidade chancelada como Patrimônio da Humanidade}

A consolidação da imagem de "Cidade Maravilhosa" contou também com a importante chancela da Organização das Nações Unidas (ONU): no ano de 2012, a

42 https://www.ioerj.com.br/portal/modules/news/article.php?storyid=25

43 Segundo "fundamentos" do branding, o co-branding funcionaria como uma forma de três de seus pilares: "brand equity" (valor agregado da marca), o "share of mind" presença no mapa mental de marcas) e o "brand awareness" (conhecimento da marca)

44 Através de tais parcerias, o símbolo da identidade visual da campanha seria estampado em produtos como Sandálias Havaianas, pingentes da marca de jóias Antonio Bernardo, em vitrines de lojas e embalagens de produtos como iogurte e café. Fonte: http://www.prole.com.br/cases/?lng=pt\#1

45 Segundo Kavaratzis (2004), enquanto $o$ city marketing trataria de questões ligadas à imagem da cidade, o city branding (além de tratar também de questões sobre a imagem) proveria a base para o desenvolvimento de políticas de desenvolvimento econômico, além de contribuir para que os residentes se identifiquem com sua cidade (KAVARATZIS, 2004, p.58. Tradução própria) 
$\mathrm{UNESCO}^{46}$ reconheceu o Rio de Janeiro como Patrimônio Mundial na categoria de Paisagem Cultural. O processo de candidatura, iniciado em 2009, teve a proposta elaborada pelo Instituto do Patrimônio Histórico e Artístico Nacional (IPHAN), com a participação do Governo do Estado do Rio de Janeiro, por meio do Instituto Estadual de Patrimônio Cultural (INEPAC), da Prefeitura da cidade, do Instituto Chico Mendes de Conservação da Biodiversidade (ICMBio) e da Fundação Roberto Marinho. $\mathrm{O}$ argumento utilizado na candidatura baseava-se não só na questão sobre a beleza única de sua paisagem física, mas principalmente, a partir da relação entre homem e natureza, da cidade que, como apontamos anteriormente, seria vivida entre o mar e as montanhas:

Reconhecida como uma das cidades mais belas do mundo, o Rio de Janeiro encontra na relação entre homem e natureza a âncora para a sua candidatura a Patrimônio Mundial na categoria de paisagem cultural. Cidade que nasceu e cresceu entre o mar e a montanha, seus principais elementos que a tornaram excepcional e maravilhosa já são, há tempos, mundialmente conhecidos, como o Pão de Açúcar, o Corcovado, a Floresta da Tijuca, o Aterro do Flamengo, o Jardim Botânico e famosa praia de Copacabana. ${ }^{47}$

A ocasião da conquista somava-se ao momento de euforia e orgulho da cidade vivido pelos cidadãos, que agora viam, através do título, a legitimação da paisagem dos cartões postais da cidade como um Patrimônio Mundial da Humanidade, digno de estar entre os mais importantes cenários de todo o mundo. Sabe-se que um título cedido pelas Nações Unidas é de significante valor para o reconhecimento internacional da cidade, uma forma de referendar "o olhar da comunidade internacional sobre os valores da cidade", como aponta o representante da UNESCO no Brasil, Lucien Muñol ${ }^{48}$. Para uma cidade que pretendia entrar na "rede global de cidades", como o Rio de Janeiro, tal chancela mostrava-se com um importante validador de seu potencial turístico ${ }^{49}$.

Em 2009, iniciou-se o processo de candidatura na categoria "Paisagem Cultural". Criada em 1992, tal categoria seria destinada a áreas onde "a combinação entre

46 Agência das Nações Unidas que atua nas áreas de mandato Educação, Ciências Naturais, Ciências Humanas e Sociais, Cultura e Comunicação e Informação.

47 Fonte: http://portal.iphan.gov.br/noticias/detalhes/1604/unesco-recebe-dossie-da-candidaturado-rio-de-

48 Fonte: https://nacoesunidas.org/unesco-aprova-rio-de-janeiro-como-patrimonio-mundial-dahumanidade/

49 A busca pelo título de Patrimônio, pela UNESCO, havia sido iniciada em 2002, ocasião na qual buscou-se inserir a cidade na categoria de "sitio misto". 
Patrimônio Cultural e Natural, bem como as ligações intrínsecas entre as comunidades e seus ambientes naturais tivessem um caráter excepcional e, por isso, merecessem ser preservadas" (RIBEIRO, 2016, p.51).

Sob o título "Rio de Janeiro: Paisagens Cariocas entre a Montanha e o Mar", o dossiê entregue pelo IPHAN naquele ano propunha o reconhecimento de parte do patrimônio urbano da cidade ${ }^{50}$, sob o argumento que a cidade seria um exemplo de integração entre natureza e arquitetura, onde morros, florestas e mar conformariam a vida urbana da cidade e dariam origem à "cultura de rua", uma representação similar ao que se produzia também nas campanhas publicitárias apresentadas aqui.

Como atributos para a candidatura, o dossiê baseou-se em três critérios estabelecidos nas Diretrizes Operacionais para Aplicação da Convenção do Patrimônio Mundial. O critério I, sobre "representar uma obra-prima de um gênio criativo humano", foi descrito através de intervenções de profissionais renomados que teriam tornado a cidade internacionalmente conhecida pelo patrimônio paisagístico, sendo eles o escultor Valentim da Fonseca, o botânico francês Auguste Glaziou, o arquiteto Affonso Eduardo Reidy e o paisagista Roberto Burle Marx, responsáveis pelos projetos do Passeio Público, do Jardim Botânico, do Parque do Flamengo e da Praia de Copacabana, respectivamente.

O critério II das diretrizes também fora apontado como próprio da capital carioca. Nele, colocava-se que a cidade deveria "ser testemunho de um intercâmbio de influência considerável, durante um dado período ou numa determinada área cultural, sobre o desenvolvimento da arquitetura ou da tecnologia, das artes monumentais, do planejamento urbano ou da criação de paisagens". Através de tal questão, o dossiê apontaria para a complexidade da paisagem cultural produzida pelas diferentes apropriações da natureza, desde o período de colonização dos portugueses - que seria vinculado apenas a questões de interesse econômico -, passando pela utilização da cafeicultura (segunda metade do século XIX), a qual teria suscitado discussões sobre a preservação da mata da cidade, confluindo

50 Área composta por: setores da Floresta da Tijuca, Pretos Forros e Covanca do Parque Nacional da Tijuca; o setor Pedra Bonita e Pedra da Gávea, do Parque Nacional da Tijuca; setor Serra da Carioca do Parque Nacional da Tijuca e Jardim Botânico do Rio de Janeiro; e a entrada da Baía de Guanabara e suas bordas d'água desenhadas: Passeio Público, Parque do Flamengo, Fortes Históricos de Niterói e Rio de Janeiro, Pão de Açúcar e Praia de Copacabana ${ }^{50}$. 
posteriormente para a criação do Parque Nacional da Tijuca. Sobre tais transformações, o documento aponta ainda para o período do Século XX, no qual a flora nativa brasileira passaria a ser valorizada e disseminada por Roberto Burle Marx.

Já o item IV, o último a ser utilizado na elaboração do dossiê do IPHAN, aponta para o critério de "estar direta ou materialmente associado a acontecimentos ou tradições vivas, ideias, crenças ou obras artísticas e literárias de significado universal excepcional". Neste caso, o relatório justificaria que a cidade sempre havia sido inspiração para criações através da música, literatura, cinema, fotografia e pelo relato de viajantes, os quais teriam retratado a exuberância e peculiaridades da cidade. Ainda sobre o item IV, apontam para "tradições vivas" tais como o carnaval de rua, o samba, a bossa nova, o futebol e as tradicionais festas religiosas.

As áreas englobadas no dossiê seriam os morros da Babilônia, São João, Saudade, Cabritos, Catacumba, que delimitam os bairros de Copacabana, Botafogo e Lagoa, o Morro da Viúva no Flamengo, o vale do Cosme Velho e Laranjeiras e a encosta sul do Morro de Santa Teresa até encontrar a borda do Parque do Flamengo, no centro da Cidade. Inclui também a Lagoa Rodrigo de Freitas e o bairro do Jardim Botânico, como amortecimento tanto para a encosta do Parque Nacional da Tijuca como para o Jardim Botânico do Rio de Janeiro, assim como as áreas verdes adjacentes ao Parque do Flamengo (Passeio Público, Praça Paris e Marechal Deodoro, Praça do Russel e jardins do Palácio da República) como reforço à sua proteção. E, como amortecimento para o Pão de Açúcar, o bairro da Urca (IPHAN, 2009).

Através de tais pontos, o Rio de Janeiro passava a ser reconhecido internacionalmente pela UNESCO como um exemplo singular de interação entre o homem, a cidade e a natureza. Segundo a representação construída no Dossiê, a cidade seria formada através de tal troca, constituindo-se como um conjunto de áreas públicas, jardins históricos e parques e monumentos naturais dignos de serem partilhados por toda a humanidade e gerações do presente e futuro ${ }^{51}$. Tal cenário, por sua unicidade, deveria ser preservado.

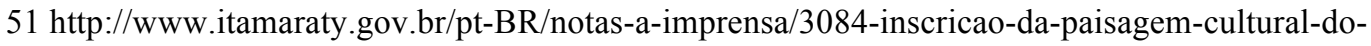
rio-de-janeiro-na-lista-do-patrimonio-mundial-da-unesco 
Entre os benefícios apontados para os "portadores" do título de Patrimônio Mundial da UNESCO, fala-se sobre seu potencial de divulgar a cidade internacionalmente e atrair turistas, assim como sobre a oportunidade para que políticas públicas de preservação das paisagens contempladas possam ser implementadas. No contexto pontuado até aqui, se por um lado, uma melhor conservação de tais patrimônios poderia trazer benefícios aos locais e à cidade, por outro, é preciso estar atento à dualidade existente entre a questão habitacional e patrimonial (HUGENIN \& ANDRADE, 2014), especialmente no que se refere a áreas de locais de habitações tidas como "informais", tais como as favelas.

O Dossiê, apesar de esboçar esforço para falar sobre a pluralidade da cidade, acaba traçando em seu texto os mesmos elementos presentes em cartões postais. Ao referir-se ao item IV das diretrizes operacionais, o dossiê aponta que

A diversidade cultural é marca de muitas grandes cidades. Na cidade do Rio de Janeiro expressa-se na relação da urbe com o mar, a floresta e as montanhas e a contribuição do homem a essa paisagem. Mais do que usos, há na cidade do Rio de Janeiro uma singularidade dos processos sociais que deram origem à forma e vice e versa. Os usos sociais das ruas, os espaços à beira mar, a orla da lagoa, os parques e as praças promovem encontros entre mar, floresta e cidade, entre morro e asfalto, moldando ativamente a paisagem cultural. (IPHAN, 2009, p.21)

O trecho acima poderia ser colocado como o que mais se aproximaria da inclusão das favelas na descrição da cidade (juntamente com a inclusão do samba e do carnaval na listagem de itens próprios das "tradições vivas"). Termos como "diversidade cultural" e "contribuição do homem a essa paisagem", poderiam influenciar o imaginário do leitor por tal caminho. Porém, a ausência de outras menções mais diretas dificulta a conexão dos elementos - principalmente de um olhar estrangeiro, como o dos júris da UNESCO. Vale destacar ainda que o uso da dicotomia "morro e asfalto" vai contra o discurso da diversidade cultural que o dossiê se propõe a exaltar. Não é novidade a discussão sobre como a ideia de "morro" versus "asfalto" seria representativa de uma "divisão do "estado de natureza' vivido por certas populações, em contrapartida ao civilizado 'domador da natureza"” (BARBOSA, 2012a, p. 34), entre aqueles que viveriam em condições subalternas e os que experienciariam o progresso, o estilo de vida civilizado. 
Para além de tais questões, ao longo do dossiê, composto por 108 páginas, a palavra "favela" aparece seis vezes ao longo do texto. Em nenhuma delas o termo é usado para fazer referência ao patrimônio cultural da cidade. Pelo contrário, tais espaços são colocados como um problema real da cidade, mas que, segundo o texto, já estariam recebendo "devidos investimentos" de urbanização, ao mesmo tempo que sendo controlados para não avançarem pela floresta. Na primeira aparição no documento (parte na qual é utilizado três vezes), a palavra aparece ligada ao item "IV.B Fatores que afetam o sítio"; na segunda, o termo é utilizado no item "IV.B.2 Fatores ambientais", trazendo questões sobre área de risco, desmatamento e acúmulo de lixo; na terceira, é endereçado à parte onde fala-se sobre "Políticas e Programas relacionados à Conservação e Promoção do Sítio, no qual citam o PAC Favelas; na quarta e última aparição, aparece ligado ao título "Preservação da paisagem pela legislação urbanística", o qual, na parte destinada ao termo, faz-se uma contextualização histórica sobre o surgimento dos "primeiros instrumentos urbanísticos com preocupação de controle da ocupação das encostas, com foco na proteção da floresta" (p.75).

Através de tais questões, a proposta acaba por construir uma representação da cidade com extrema similaridade ao pensamento que já vinha sendo pautado pelas campanhas publicitárias, tendo a ideia da Cidade Maravilhosa como pano de fundo da imagem. Uma representação que, novamente, foca na vida presente - majoritariamente - na Zona $\mathrm{Sul}^{52}$ do Rio de Janeiro baseia-se na história da cidade tida como "formal": o Rio de Janeiro da colonização portuguesa, da paisagem dos pés de café, de Burle Marx, do Parque do Flamengo e dos outros tantos parques e jardins. De uma cidade pintada por Marc Ferrez, da música "de exaltação às praias, que se espalha pela cidade como um todo" (IPHAN, 2009, p.47), de uma cidade na qual "constata-se que as territorialidades culturais apresentadas refletem a relação dinâmica entre seus habitantes e a natureza, que influenciou o desenho da cidade do Rio de Janeiro e de sua paisagem" (IPHAN, 2009, p.47).

52 Como aponta o dossiê: "Engloba a parte da cidade que cresceu na estreita faixa de planícies aluviais entre a Baía de Guanabara, o Oceano Atlântico e as montanhas, que ao longo do tempo recebeu intervenções paisagísticas excepcionais na sua borda d'água, construídas para a defesa da cidade ou para o lazer da população.” (p.22-23) 


\subsection{3}

\section{A cidade construída para o espetáculo urbano}

Somado aos discursos e representações construídas por ferramentas publicitárias e chanceladas por títulos internacionais, transformações de ordem físico-espacial também buscariam produzir a "nova" imagem do Rio de Janeiro. Como já apontado no capítulo 2, a utilização de megaprojetos e transformações urbanas para construir a "imagem-marca" de cidades seria uma ferramenta vastamente utilizada entre as cidades pretendidas como "internacionais". No contexto do Rio de Janeiro, tal cenário não foi diferente.

Através de intervenções urbanas e novos ícones arquitetônicos, buscou-se não apenas reforçar o caráter de "Cidade Maravilhosa" apontado até aqui, mas, principalmente, concretizar requisitos desejáveis para as cidades consideradas "bem-sucedidas" na rede global: os projetos urbanos, vistos como motivadores de dinâmicas transformadoras do espaço urbano (SÁNCHEZ, 1999), seriam usados no contexto do Rio de Janeiro para materializar o caráter inovador da cidade, digno do momento vivido na capital. Os partidos arquitetônicos adotados construiriam novos ícones para compor sua imagem-marca, demonstrando o desejo latente de tornar a “Cidade Maravilhosa” em uma Cidade Espetáculo ${ }^{53}$.

O projeto desenvolvido na região portuária da cidade, uma Operação Urbana Consorciada $^{54}$, demonstra tal questão. Sua extensão abrangeria uma área de cerca de cinco milhões de metros quadrados, entre os bairros da Gamboa, Saúde e Santo Cristo, incluindo as favelas da Providência, Pedra Lisa, Moreira Pinto e São Diogo, além de trechos de São Cristóvão, Centro, Caju e Cidade Nova. Dentre as intervenções urbanas e obras de infraestrutura, a operação previa investimentos como o da reestruturação das redes de abastecimento de água, de esgoto e telecomunicações. Era proposto também um novo conceito de mobilidade para a

53 "A aspiração de colocar a cidade no novo mapa do mundo é perseguida por hábeis gestores do city marketing que fabricam também uma nova cidadania, um novo modo de ser e viver na cidade. É o que chamamos de cidade-espetáculo. Enquanto para fora, a cidade é vendida mediante estratégias que incrementam seu atrativo comercial, turístico e cultural buscando atrair grandes investimentos, para dentro, a mercadotecnia urbana engendra uma visão de cidadania que assalta, especialmente, os próprios cidadãos.”. (Sánchez, 1999, p.27)

54 Recurso previsto pelo Estatuto das Cidades (Lei Federal $n^{\circ} 10257 / 2001$ ) com o objetivo de fomentar a recuperação de áreas degradadas. 
área central da cidade, sendo este composto pela implosão do elevado da Perimetral, e a implantação do Veículo Leve sobre Trilhos (VLT) (WERNECK, 2016).

A reurbanização prevista no projeto, além das alterações no sistema viário, estabeleceria nova codificação do zoneamento - a qual permitiria o aumento do gabarito na faixa do porto -, novos edifícios públicos, tais como o Museu de Arte do Rio, o Museu do Amanhã e o AquaRio (maior aquário marítimo da América do Sul), além de abranger também o projeto Frente Marítima - Orla Prefeito Luiz Paulo Conde -, o qual resultaria na reurbanização da área de implosão do antigo elevado da perimetral, indo desde o Museu Nacional até o armazém 8.
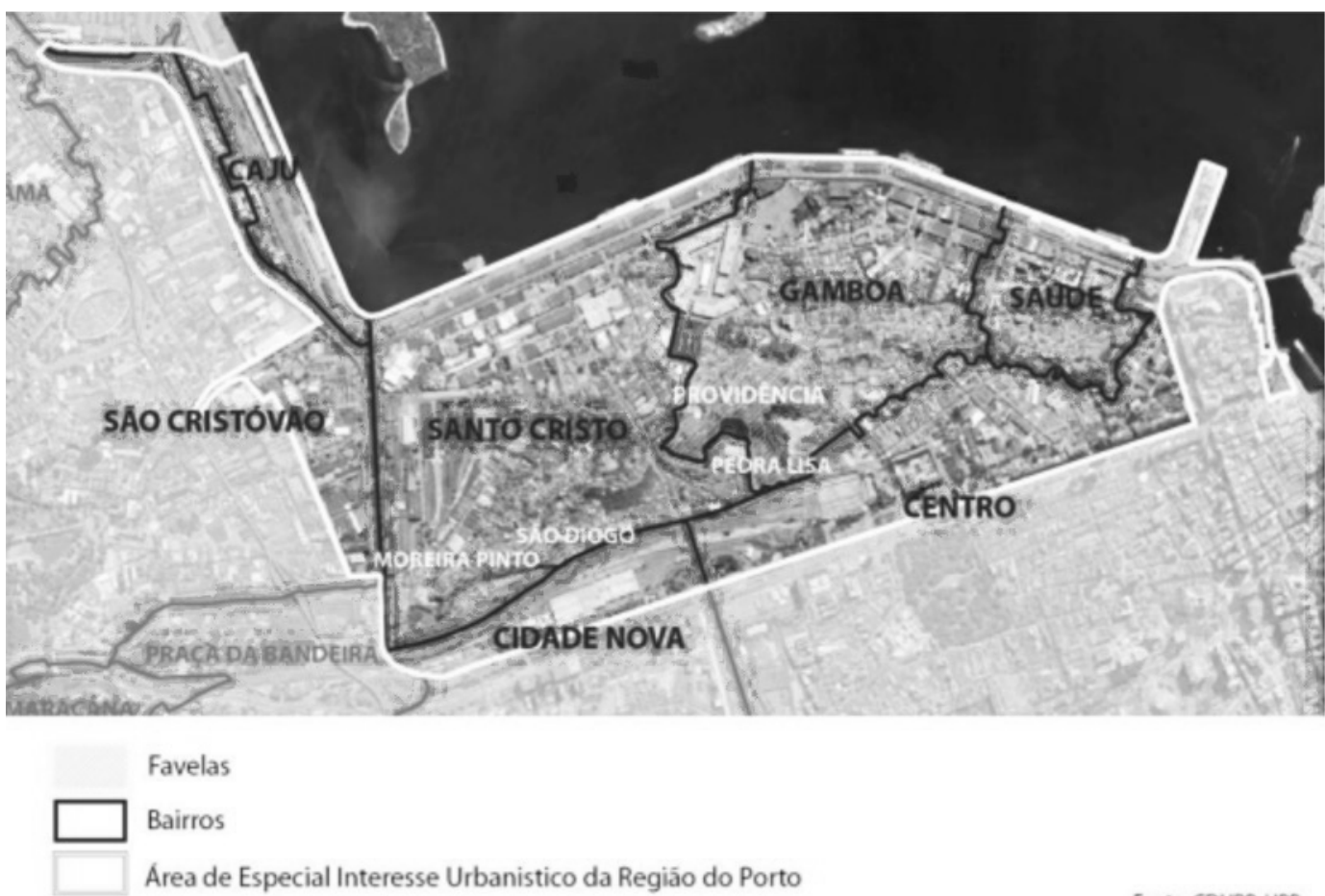

Figura 7 - Elaboração: CDURP/ Instituto Pereira Passos (2015). Fonte: Observatório de Metrópoles A chamada Operação Urbana do Porto Maravilha é representativa da lógica que pautava a cidade no momento em questão. Como aponta Werneck (2017), o modelo utilizado no projeto da região portuária seria marcado por um arranjo inédito que combinaria parcerias público-privadas e instrumentos do mercado de capitais, "um processo que determina um novo padrão de relação entre o poder público e o setor privado, inaugurando, por um lado, um novo modelo de gestão da cidade, e, por outro, acirrando as desigualdades socioespaciais do Rio" (WERNECK, 2017) ${ }^{55}$.

55 Resumidamente, o processo de arranjo financeiro do projeto se deu da seguinte forma: para gerir o projeto pretendido para a área, a Prefeitura criou a Companhia de Desenvolvimento Urbano da 
A “corrente de pensamento" própria da cidade-mercadoria utilizada na produção do espaço carioca, pode ser vista também através das intervenções urbanas propostas para a área. Como mostrado a partir de Jacques (2004) no capítulo 2, o processo de “espetacularização das cidades contemporâneas" seria pautado por duas possíveis correntes de pensamento que poderiam ser adotadas simultaneamente em uma mesma cidade. A primeira corrente, buscaria "petrificar" o espaço, levando-o à museificação e à patrimonilização; a segunda, ao basear-se em princípios modernistas, tal como a tábula rasa, adotaria o projeto de grande escala, próprio das cidades genéricas. Ambas as correntes pareciam ter indícios de existência no projeto que se desenvolvia na cidade: enquanto o título da UNESCO tornaria uma considerável área da cidade Patrimônio da Humanidade, o projeto desenvolvido na região portuária seria regido por diretrizes próprias da segunda corrente descrita por Jacques.

O Porto Maravilha, maior operação urbana desenvolvida no país até então, teria crucial importância para a representação que se pretendia construir para a cidade. A região era pretendida como símbolo da superação da "sensação de crise" e de "reconstrução da cidade", desvelando o "novo momento" que a capital vivia: o megaprojeto seria o "grande legado" que o Rio de Janeiro e os cariocas ganhariam com as Olímpiadas, segundo a Prefeitura.

Neste contexto, ações para "revitalização" e "renovação urbana" da área seriam não só concebidas e justificadas, mas vistas também como o caminho que impulsionaria o "sucesso" da cidade. O discurso do então prefeito Eduardo Paes durante a

Região do Porto do Rio de Janeiro (CDURP) - formada pelas empreiteiras Odebrecht, Carioca Engenharia e OAS -, a qual tinha como objetivo gerir e fiscalizar a chamada "revitalização" . A CDURP faria a articulação entre a Prefeitura e a Concessionária Porto Novo, a qual havia sido contratada via licitação para executar obras e prestar serviços municipais à região até o ano de 2026. Vastamente divulgada pela Prefeitura como a maior Parceria Público-Privada do país, defendia-se que o uso do instrumento permitiria o compartilhamento de riscos entre poder público e ente privado (WERNECK, 2017). Como forma de conseguir recursos para a operação urbana, o potencial de construção da região foi aumentado para atrair investidores, os quais deveriam comprar os Certificados de Potencial Adicional Construtivo (CEPAC) para, assim, poder construir no local. Os CEPACs - vendidos em lote único ao FGTS -, blindariam o orçamento municipal de gastos. Mariana Werneck (2017) questiona através de seu artigo a eficácia da PPP na ocasião da Operação Urbana do Porto Maravilha e dos instrumentos utilizados. Segundo Werneck, o modelo teria, pelo contrário, onerado financeiramente o poder público e resguardado os interesses privados. Um dos motivos apontados seria a recompra de 168 mil CEPACs pela CEDURP ao longo dos últimos, significando, assim, a utilização de verba pública (municipal) para obtenção de certificados emitidos pelo próprio município. 
cerimônia de inauguração da "nova" Praça Mauá - parte importante da operação urbana - é representativo sobre tais aspectos:

Minha geração via a Praça Mauá como um local negativo, que só tinha o título de praça no nome, mas não era frequentada por ninguém. É muito bom poder ver essa área, que representava um Rio decadente, totalmente revitalizada e com tantas pessoas. Que a Praça Mauá sirva de exemplo e inspiração para esse novo Rio que olha para frente. ${ }^{56}$

Ao utilizar expressões como "local negativo", "decadente", "revitalizada"57 e "novo Rio que olha para frente", a fala passa a justificar um projeto para o espaço que seria pautado pela noção da tábula rasa, apontada anteriormente. O discurso do prefeito é parte da reportagem da própria Prefeitura sobre a ocasião do evento. Além de outros elementos presentes ao longo do texto que parecem também justificar a lógica utilizada no projeto, vale aqui destacar o título dado à matéria: "Praça Mauá de volta para o futuro". Tal título remete a Mello \& Vogel (2005), quando sugerem que

O discurso progressista e racionalista na arquitetura e no urbanismo contemporâneos parece desempenhar um curioso papel de máquina do tempo ao contrário. Não nos desloca para o futuro. Traz-nos o futuro, ou aquilo que se supõe que seja o futuro. (MELLO \& VOGEL, 2005, p. 309)

Ainda segundo os autores, tal discurso colocaria que o presente seria cheio de impurezas, sendo o "ideal” encontrar um vazio para que o discurso da razão técnica pudesse, então, preenchê-lo, criando os espaços segundo o destino pretendido. João Masao Kamita (2015) traça uma interessante análise sobre o projeto da Praça Mauá que converge com esta discussão de Mello \& Vogel (2005):

Os verbos fundamentais do partido são todos subtrativos: implodir a perimetral, desfazer as ruas limítrofes que cerceavam o livre movimento, destituir a prerrogativa do automóvel frente ao pedestre. Na nova Praça Mauá extrair ao invés de construir, eis o gesto primordial. Nessa ação, a superfície em certo sentido repõe sua condição originária de tábula rasa quando das obras de aterramento no início do século 20 que estabeleceram suas dimensões primeiras. Uma grande esplanada se abriu outra vez como território da disponibilidade moderna. (KAMITA, 2015)

56 Fonte: http://www.rio.rj.gov.br/web/guest/exibeconteudo?id=5570823

57 Vale salientar que o termo "revitalização" aparece no discurso do ex-prefeito com o mesmo peso do contexto descrito por Arantes no capítulo 2, ao abordar ferramentas de uma "fórmula salvadora" das cidades. Segundo a lógica da Prefeitura, ao "trazer à vida" um espaço onde não haveria nada além da decadência, a cidade poderia atrair turistas e investimentos estrangeiros. Cabe destacar que a região portuária é reconhecida como um importante polo cultural da cidade. O espaço é parte da história e herança africana para a cidade e para o país. À época da inauguração da Praça Mauá e do discurso do então prefeito sobre "revitalização", a região possuía fortes manifestações culturais próprias, principalmente de caráter musical. 
A partir do "terreno limpo", novas representações para o espaço poderiam ser concebidas pelos cientistas, planejadores ou 'tecnocratas 'retalhados' e 'agenciadores'”, como apontaria Lefebvre (2006a). O projeto da Praça Mauá, assim como de toda a operação urbana do Porto Maravilha, ao buscar definir o que seria o "futuro" e determinar os usos anteriores como degradados, subjuga o espaço vivido e percebido ao espaço concebido por si.

Esta não teria sido a primeira vez na região onde intervenções urbanas foram realizadas visando transformar o caráter social do espaço. A região portuária, conhecida também como "Pequena África", foi palco de diferentes mudanças ao longo dos séculos que buscavam, assim como o discurso supracitado, esconder o que se considerava como "decadente". A área, cabe salientar, tem uma grande importância histórica para a cidade. Antes uma área de chácaras, o desenvolvimento urbano da região é acelerado por volta de 1763, quando o Rio de Janeiro torna-se capital do Brasil Colônia. Com o crescimento da cidade na ocasião, o processo de urbanização expande-se para sua direção norte, nos Morros da Conceição e Providência. O mercado de escravos da Praça XV é transferido para o Valongo (localizado na região atual do porto), influenciando o desenvolvimento de atividades portuárias na região e transformando-a em pólo de comércio de escravos. Estima-se que entre 1774 e 1831 , entre 500.000 e 700.000 africanos escravizados chegaram ao Brasil através do Cais do Valongo. Segundo Galiza (2015):

O crescimento da atividade portuária propiciou a ocupação dos morros e planícies de toda a área e a formação dos bairros da Saúde, Gamboa e Santo Cristo. Essa região, conhecida (até hoje) como "Pequena África", era considerada a parte mais velha, decadente e pestilenta da cidade. Era o lugar dos escritórios decorretores de escravos, dos armazéns-depósitos para os negros recém-chegados, das oficinas destinadas à fabricação de objetos para prender e torturar os escravos, local do matadouro da cidade e das tabernas frequentadas por marinheiros e ciganos. (GALIZA, 2015, p. 77)

A chegada da Família Real ao Brasil, em 1808, e o consequente aumento das atividades portuárias e desenvolvimento urbano e de transporte ${ }^{58}$, dinamizaram as atividades do entorno e aumentaram o numero de habitações de novos trabalhadores que chegavam à capital. A região consolidava-se, assim, como uma área caracterizada por moradias coletivas em cortiços, estalagens e casebres, os quais

58 Com a construção da Estrada de Ferro, hoje a Central do Brasil. 
seriam habitados por escravos, ex-escravos imigrantes europeus e, mais tarde, por nordestinos (GALIZA, 2015).

Em 1843, a primeira "revitalização urbana" da região é realizada para a criação de um novo porto, próprio para a chegada da Princesa italiana Tereza Cristina de Bourbon, a qual casaria com Dom Pedro II. Os vestígios da escravidão, a qual já não era vista com "bons olhos" à época, precisariam ser escondidos. Assim, a chamada Rua do Valongo passou a ser Rua da Imperatiz, construindo-se uma estrutura por cima do Cais do Valongo.

Já no início do século XX, após a abolição da escravatura, a reforma urbana promovida na cidade pelo então prefeito Pereira Passos, iria não só apagar os vestígios que restavam do cais do Valongo, como também iria demolir grande número de imóveis da região para alargamento das vias, construção do novo porto e abertura da Avenida Central. O discurso proferido à época seria de melhoria da imagem da capital do país para atrair bons negócios para a cidade, sendo necessário liquidar o tecido urbano colonial, representação de atraso (GALIZA, 2015). A região portuária, a qual teria vestígios de insalubridade, segundo a lógica corrente, precisaria ser higienizada ${ }^{59}$. Nas décadas decorrentes, apesar de grandes vias e alguns projetos urbanos pontuais, o tecido edificado da Zona Portuária manteve-se preservado. Mesmo com diferentes propostas de "renovação urbana" para a região, somente a partir da Operação Urbana do Porto Maravilha, um projeto seria efetivamente desenvolvido.

Nele, noções como "revitalização" e "renovação urbana" seriam adotadas de forma muito similar em diferentes cidades do mundo como alternativas para construir tal ideal de "futuro". Sánchez (1999), ao abordar tal postura, que se tornava comum na década de 1990, parece estar descrevendo o que seria projetado para o Rio de Janeiro em 2009:

Falamos também das áreas de renovação urbana cuja proposta é transformá-la nas almejadas 'novas centralidades', aglutinadoras de comércio, serviços e opções culturais ou de lazer. Seus lócus são os tecidos urbanos apresentados antes como degradados, áreas de antigas fábricas, frentes marítimas ou armazéns em velhas

59 O artigo "Grandes eventos, obras e remoções na cidade do Rio de Janeiro, do século XIX ao XXI", de Galiza, Vaz e Silva (2014), as autoras abordam o caso do cortiço Cabeça de Porco (remoção emplemática da gestão de Pereira Passos) como um dos primeiros exemplos de caso entre grandes obras públicas, remoções de moradores pobres, mercado imobiliário e ações de agentes politicos, governantes e proprietários imobiliários. 
áreas portuárias, agora refuncionalizados e 'revitalizados' para formar novos complexos de consumo em sintonia com os padrões culturais dominantes. (SÁNCHEZ, 1999, p.26)

Ao adotar o modelo de renovação de regiões portuárias, replicado por tantas cidades (DINIZ, 2014), o Rio de Janeiro parecia seguir “à risca" pré-requisitos da proposta de Borja e Castells (1996) para a inserção à "rede globalizada de cidades". Como consequência, a cidade carioca passava a assumir paisagens urbanas idênticas a tantos outros locais. Os projetos pareciam agregar à "Cidade Maravilhosa" os cenários próprios da "cidade genérica", descrita por Rem Koolhaas $(2010)^{60}$. Ainda a partir da visão de Sánchez (1999):

A cidades da virada de século parecem assemelhar-se. Sobretudo, se atentarmos para os seus novos espaços, promovidos internacionalmente como pontos luminosos de roteiros globais, produzidos por uma arquitetura espetacular e um urbanismo integrado aos padrões éticos e estéticos da mundialização. (SÁNCHEZ, 1999, p.26)

Diferentes representações gráficas que simulavam projetos futuros para a região apontavam tal tendência na cidade carioca:

60 Ao apontar a questão da semelhança, Koolhaas ironiza: "Será a cidade contemporânea como o aeroporto contemporâneo (igual a todos os outros)?”. (KOOLHAAS, 2010, p.31) 


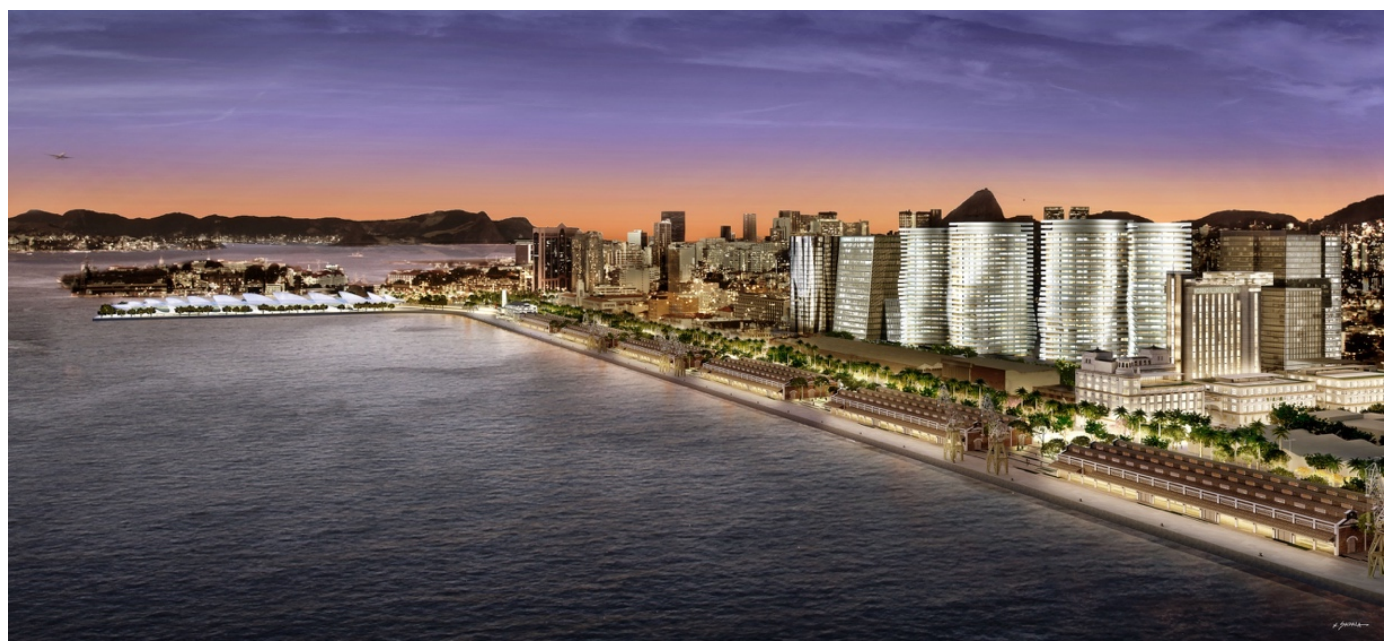

Figura 8 - Representação visual do porto do Rio de Janeiro, disponibilizado no site da Prefeitura.

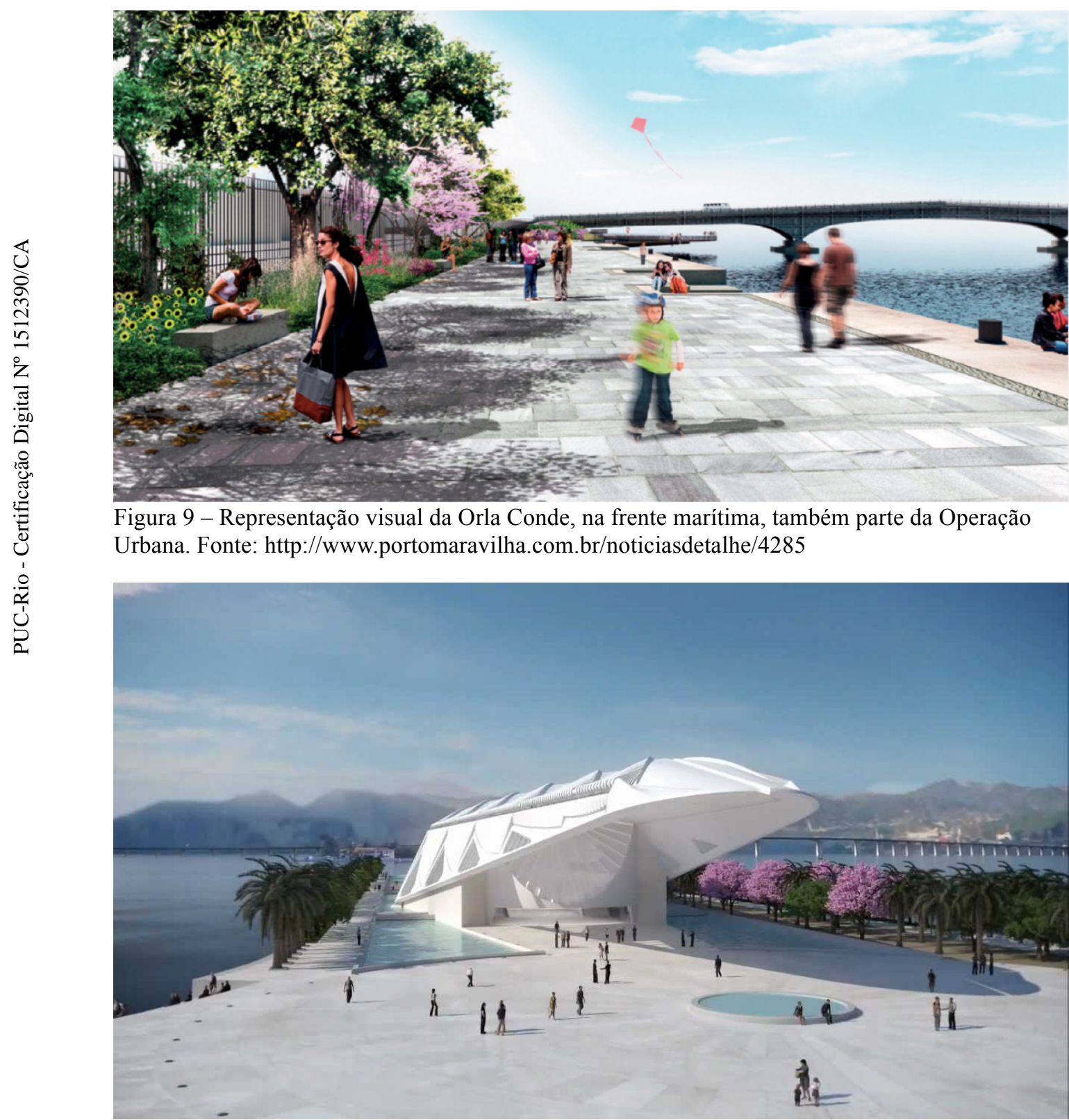

Figura 10 - Representação visual do projeto do Museu do Amanhã. Fonte: https://arcoweb.com.br/finestra/arquitetura/santiago-calatrava-museu-amanha-rio-janeiro-2014 


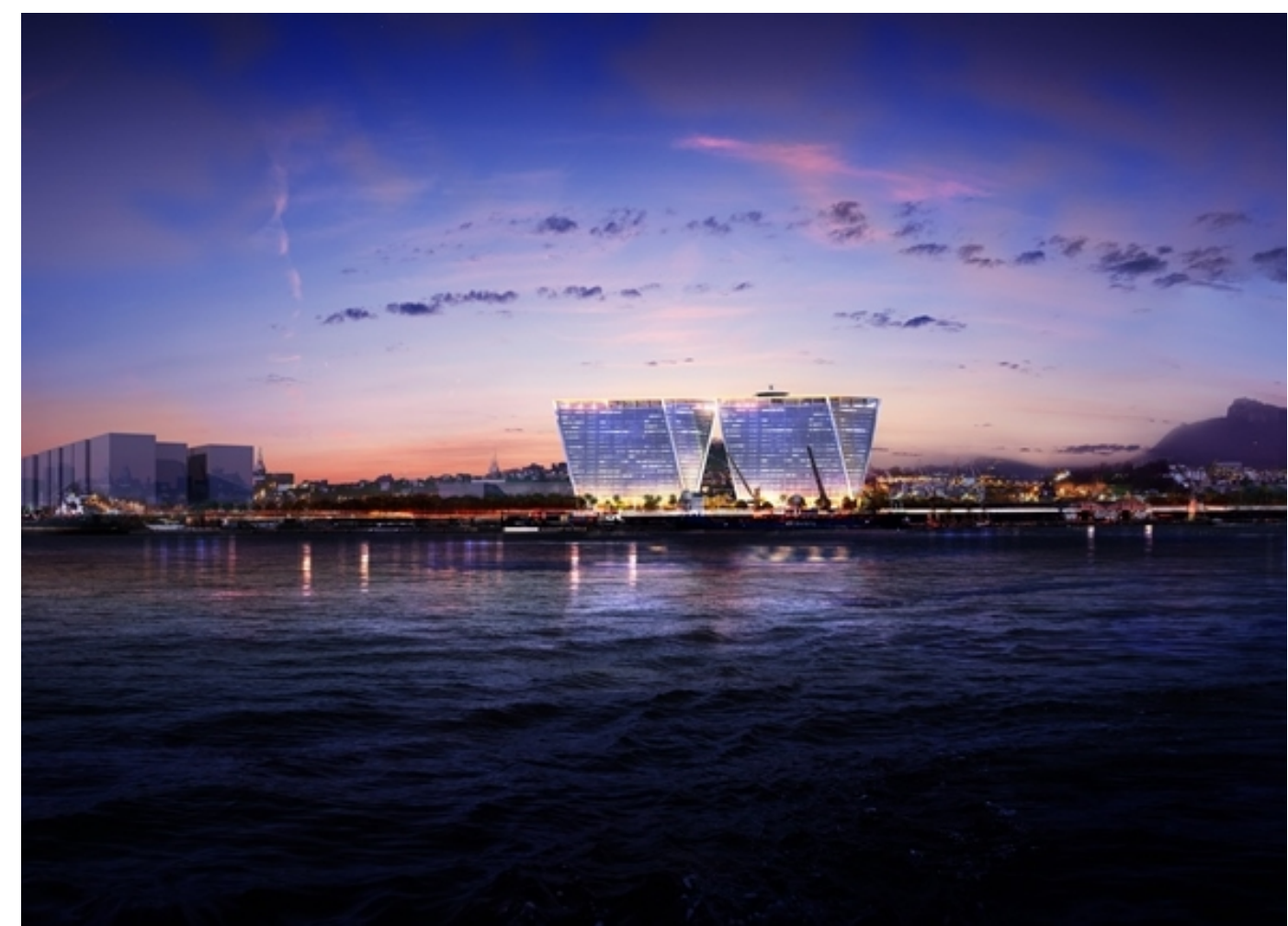

Figura 11 - Representação visual do Aqwa Corporate, assinado pelo escritório

Foster+Partners. Fonte:http://tishmanspeyer.com.br/comercial/aqwacorporate

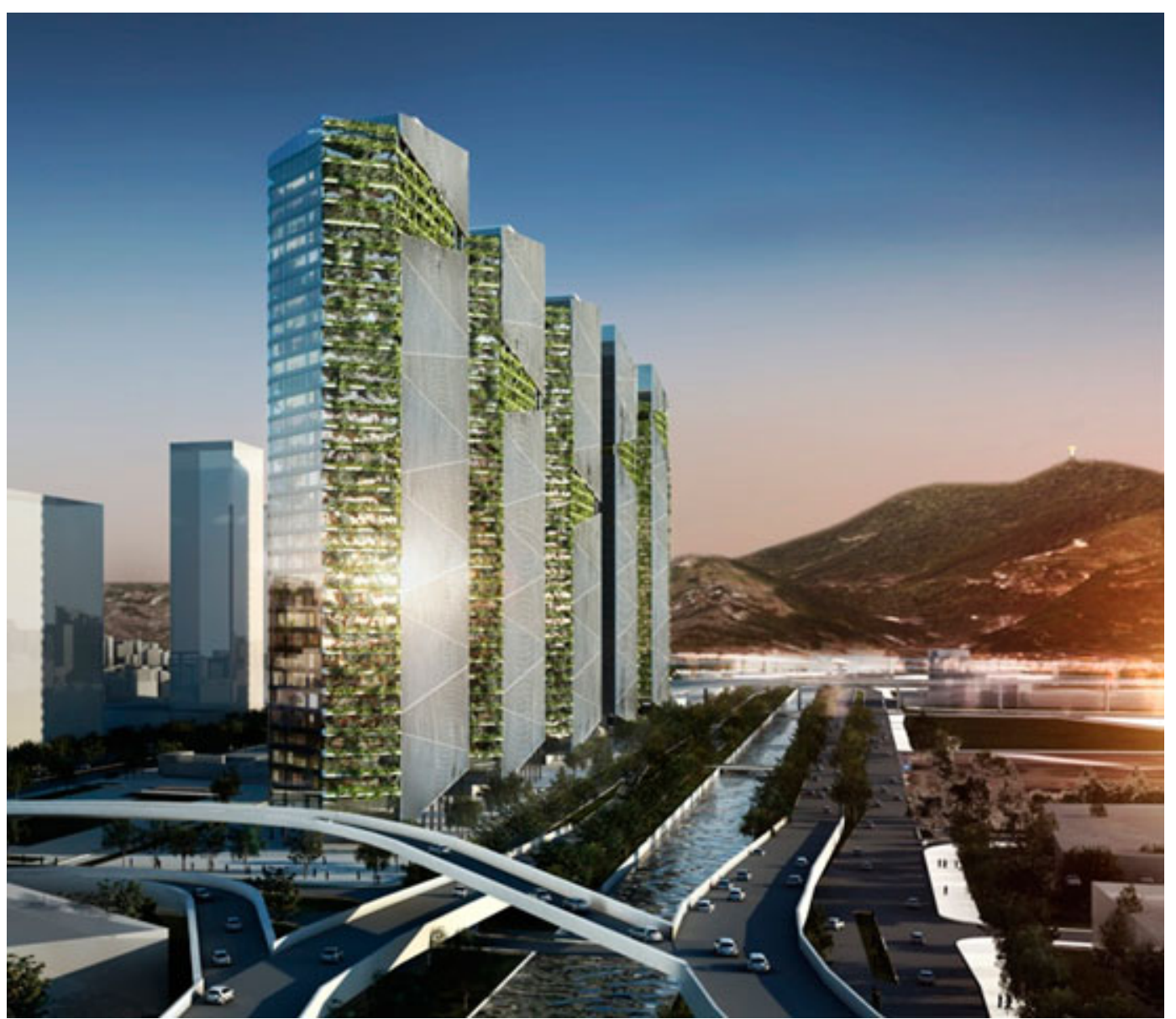

Figura 12 - Representação visual do projeto do empreendimento imobiliário Trump Towers. Fonte: http://www.portomaravilha.com.br/noticiasdetalhe/4058 
Os projetos desenvolvidos nas cinco imagens acima poderiam remeter a empreendimentos criados para diferentes cidades do mundo. Porém, a questão sobre ter uma identidade própria, condizente com o local, não parecia ser a questão em jogo na concepção de tais projetos. Estar alinhado aos padrões culturais dominantes seria o mais importante para a imagem da capital carioca no momento vivido.

Neste contexto, possuir, em seu espaço urbano, empreendimentos internacionais de famosos empresários e incorporadoras, com seus altos edifícios de formas icônicas revestidos de vidro (material que remeteria a valores como integridade e transparência) poderia mostrar ao mundo a solidez do Rio de Janeiro, uma cidade confiável, segura, própria para investidores - afinal, grandes nomes como a incorporadora americana Tishman Speyer $^{61}$ (Figura 11) e a marca Trump ${ }^{62}$ (Figura 12) teriam escolhido a cidade como palco de seus megaempreendimentos ${ }^{63}$.

Da mesma forma, segundo a lógica empregada, possuir construções assinadas por starchitects globais, tal como o espanhol Santiago Calatrava (figura 10) e o inglês Norman Foster (Figura 11) - entre outros -, demonstraria ao mundo a sofisticação que a cidade vinha ganhando, revelaria um lugar onde os criadores de famosas obras internacionais também teriam materializado seus olhares "visionários",64. A reportagem do Jornal O Globo, de 2014, ilustra tal questão: com o título "Quinze empreendimentos prometem levar futuro para a Zona Portuária, uma das mais antigas do Rio" ${ }^{65}$, a matéria diz que "Hotéis e prédios de arquitetura moderna começam a dar cara nova à região (...)".

61 Uma das maiores incorporadoras mundiais, a empresa é administradora de edifícios como Crysler e Rockefeller Center, em Nova Iorque.

62 Marca vinculada ao empresário-celebridade norte-americano Donald Trump, atual Presidente dos Estados Unidos.

63 Segundo contato com a incorporadora Tishman Speyer, há previsão de finalização de uma das duas torres para o final de 2017 - a segunda torre só irá ser iniciada com o "reaquecimento da economia", segundo a funcionária. Já o empreendimento de Trump, de cinco prédio com 38 andares, não têm previsão para ser iniciado. A Revista Veja aponta que Trump teria cancelado todos os projetos no Brasil (e em outros países) após assumir como presidente. (Fonte: http://veja.abril.com.br/economia/trump-cancela-projetos-no-brasil/).

64 Hal Foster (2015) defende que arquitetos como Norman Foster e outros de estilo similar "exploram a velha lenda do artista criador de imagens visionárias" (FOSTER, 2015, p.60).

65Fonte: https://oglobo.globo.com/rio/quinze-empreendimentos-prometem-levar-futuro-parazona-portuaria-uma-das-mais-antigas-do-rio-14218691 
O crítico Hal Foster (2015), ao analisar o trabalho de Norman Foster, especificamente, aponta para a questão relativa ao "futuro", a qual a matéria do Jornal O Globo se sustenta. Para o autor, o escritório Foster+Partners seria o que, "talvez de modo mais persuasivo do que qualquer outro escritório, produz uma imagem arquitetônica de um presente que deseja parecer avançado" (FOSTER, 2015, p.70).

Cabe aqui exemplificar tais colocações através do vídeo de apresentação/divulgação do empreendimento "Aqwa", da Tishman Speyer projetado pelo escritório de Norman Foster (Figura 11). Além de demonstrar algumas questões as quais Hal Foster nos chama a atenção sobre o trabalho do arquiteto inglês, o material se mostra interessante também por ilustrar cada um dos valores que seriam desejados por investidores internacionais e que estariam sendo concretizados através das transformações urbanas do Rio de Janeiro.

O material, todo em inglês, de cerca de 4 minutos, "vende" a cidade carioca na primeira metade do tempo através de atributos como "business and events center", "a modernized city" - mostrando imagens do Museu do Amanhã -, "renovated international airport" e "domestic airport more efficient and easy to access". A imagem "forte e positiva apoiada numa oferta de infraestrutura e de serviços (...)" (CASTELLS \& BORJA, 1996, p.160) que o governo local pretendia construir, apareceria agora no discurso do investidor. $\mathrm{O}$ vídeo aponta também questões específicas sobre os "diferenciais" da região portuária - ou melhor, de sua semelhança com as grandes capitais globais e seus projetos de frentes marítimas: "amazing view of Baía de Guanabara"; "in the heart of Porto Maravilha"; "a vibrant neighborhood in the heart of Rio"; "new waterfront promenade (Orla Conde)"; "work art, culture and leisure in one place"; "two new tunnels". Através de tais elementos, a cidade seria apresentada por seus requisitos de "cidade competitiva", a qual responderia aos quesitos de ser "atraente e funcional, dotada de infraestruturas modernas e que assegure garantias mínimas de qualidade de vida e segurança pública" (CASTELLS \& BORJA, 1996, p.157). 


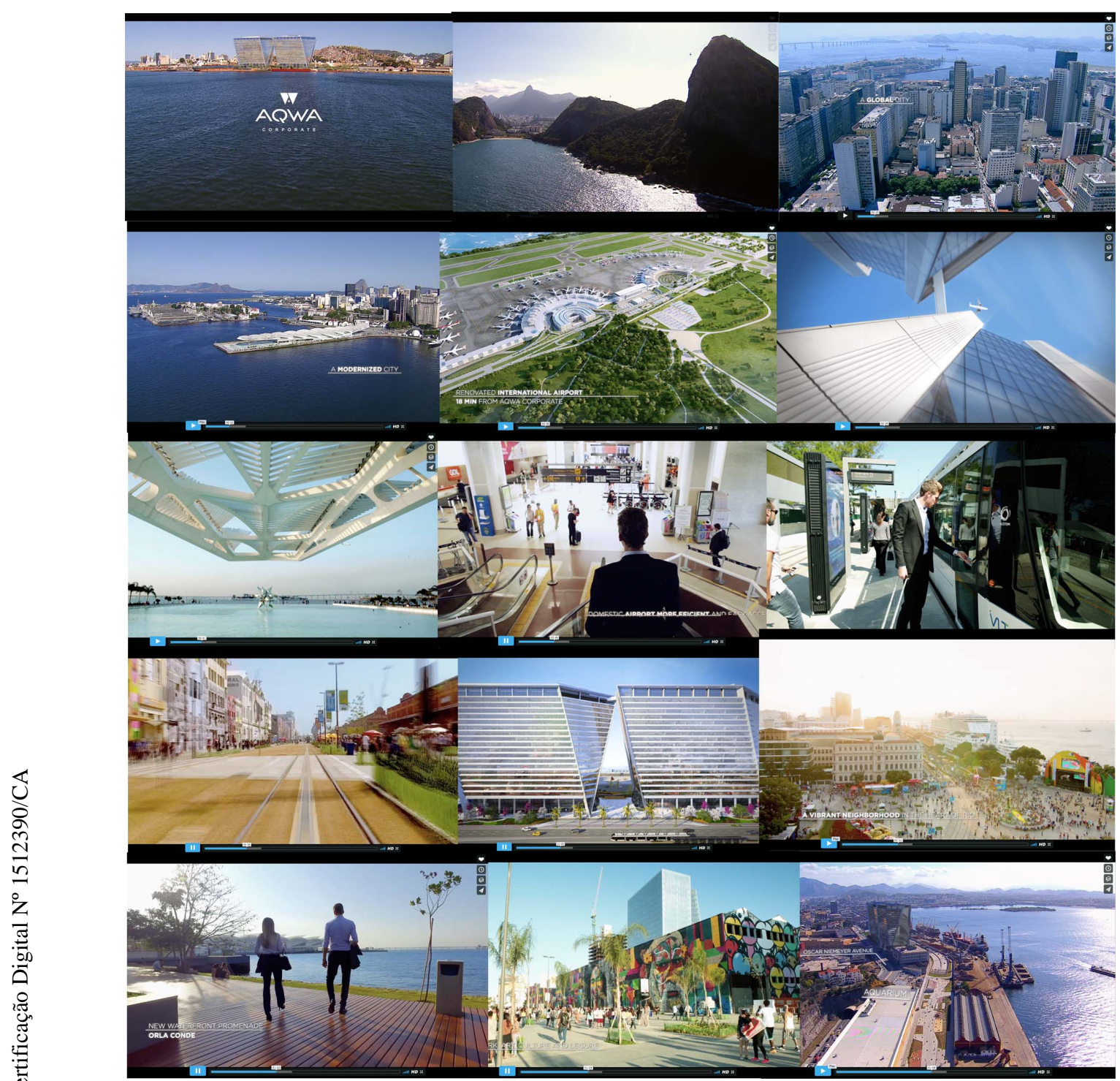

Figura 13 - imagens do vídeo do empreendimento Aqwa Corporate, apresentando os atributos da cidade e dos edifícios de escritórios desenhados por Normal Foster. Frames selecionados pela autora. Fonte: https://vimeo.com/204243007

Na representação construída para o material, o Rio de Janeiro aparece como uma "cidade global", como a denominam nos primeiros segundos de vídeo, com cenários de beleza natural exuberante, sendo os elementos arquitetônicos e instrumentos urbanos também de suma importância na construção da "narrativa" sobre a cidade. O Museu do Amanhã, projetado por Santiago Calatrava, é mostrado em diferentes momentos sob o termo "cidade modernizada". O nome Foster+Partners aparece também com destaque, demonstrando a "grife" de arquitetos que teria projetado o empreendimento Aqwa.

As formas arquitetônicas inusitadas dos projetos de Foster e de Calatrava, além de visibilidade para a cidade, atribuiriam a ela também o caráter de tecnológica e sustentável, importantes quesitos para as cidades que se pretendem como 
internacionais. No caso de Foster, ter a sua assinatura, já seria por si só um atestado de projeto tecnologicamente avançado e "green friendly" Calatrava, além de listar diversos atributos ditos sustentáveis em seu programa arquitetônico, já explicita em seu nome ao que se propõe. Segundo o site do museu: “orientado pelos valores éticos da Sustentabilidade e da Convivência, essenciais para a nossa civilização, o museu busca também promover a inovação, divulgar os avanços da ciência e publicar os sinais vitais do planeta". A proposta de conteúdo, atrelada aos atributos arquitetônicos do projeto - tanto em relação à forma, quanto às tecnologias ditas "sustentáveis" -, renderam ao Museu do Amanhã mais de dez reconhecimentos internacionais ${ }^{67}$, dentre os quais, importantes certificações de sustentabilidade e conhecidos prêmios de arquitetura $^{68}$. Tanto o projeto de Calatrava, quanto de Foster, seriam exemplos de uma arquitetura do espetáculo, a qual teria se tornado um elemento chave para as cidades-mercadoria como o Rio de Janeiro:

Uma arquitetura do espetáculo, capaz de transmitir um brilho superficial e de prazer participativo, embora transitório, de exibição, tornou-se essencial para o sucesso desses projetos de transformação urbana em curso. A fragmentação, a efemeridade, o ecletismo, a forma anteposta à função, o triunfo da imagem sobre a substância, são elementos identificáveis desta estética pós-moderna. Aqui, a arquitetura adquire uma nova obrigação expressiva nos seus marcos urbanos, onde a centralidade da forma é mais importante que a efemeridade dos espaços criados. (SÁNCHEZ, 1999, p.28)

A partir da definição pontuada por Hal Foster (2015), o museu-ícone da Praça Mauá poderia ser conceituado como característico do estilo global (estilo no qual atribui Norman Foster como um dos principais projetistas) ${ }^{69}$ :

(...) o mais característico do estilo global é seu "cosmopolitismo banal": mesmo quando seus edifícios mais representativos respondem simultaneamente às condições locais e às demandas globais, com frequência o fazem de uma maneira

66 Ver: FOSTER, 2015, p.58.

67 Títulos conquistados entre o lançamento do projeto e junho de 2017.

68 Dentre os principais, estão: Prêmio Internacional MIPIM (Categoria "Construção Verde Mais Inovadora"); selo Ouro da certificação LEED (Leadership in Energy and Environmental Design), concedida pelo Green Building Council - principal instituição americana na chancela de edificações verdes; o prêmio britânico Leading Culture Destinations Awards, ("Melhor Novo Museu do Ano"); uma medalha de ouro e duas de bronze no International Design \& Communication Awards (IDCA), no Canadá. Fonte: https://museudoamanha.org.br/pt-br/amanha-vence-premiointernacional-mipim

69 Segundo Hal Foster (2015), o estilo global estaria para nossa conjuntura pós-industrial da modernidade assim como os "estilos internacionais" de Gropius, Le Corbusier e van der Rohe apontada no capítulo 2 - estariam para a ordem industrial. Seriam expressões insignes, ao mesmo tempo pragmáticas, utópicas e ideológicas. Para o crítico, "se a modernidade tem uma aparência hoje", Norman Foster, juntamente com Richard Rogers e Renzo Piano seriam os principais projetistas (FOSTER, 2015). 
que produz uma imagem do local para ser vinculada no sentido global (um exemplo familiar é o estádio "Ninho de Pássaro", de Herzog \& de Meuron, que foi usado como logotipo da Olimpíada de Pequim de 2008.). (FOSTER, 2015, p.11)

Projetos de cunho espetacular como os que vemos na região portuária do Rio de Janeiro teriam o pretexto de "ativar" as pessoas, acabando, porém, por subjugá-las. "Quanto mais optam por efeitos especiais, menos nos envolvem como espectadores ativos" (FOSTER, 2015, p.13). Os espaços tornariam-se, assim, "pura cenografia":

As ideias situacionistas ${ }^{70}$ sobre a cidade, principalmente contra a transformação dos espaços urbanos em cenários para espetáculos turísticos, levam a uma hipótese clara: a existência de uma relação inversamente proporcional entre espetáculo e participação popular. Ou seja, quanto mais espetacular forem as intervenções urbanísticas nos processos de revitalização urbana, menor será a participação da população nesses processos e vice-versa. (JACQUES, 2005, p.18)

Os cenários criados através de uma arquitetura do espetáculo estimulariam o "patriotismo"71 de seus habitantes, o qual moldaria cidadãos acríticos, "seduzidos pelo catálogo de espaços transformados que a nova cidade lhes oferece" (SÁNCHEZ, 1999, p. 27). Enquanto o urbanismo estaria no centro da cena, o indivíduo tornar-se-ia um figurante no cenário construído para o espetáculo.

Para além da criação de cenários de lazer e cultura através de ferramentas como a arquitetura e a renovação urbana, o projeto desenvolvido na região teria ainda buscado construir o imaginário para o Rio de Janeiro de cidade histórica, a qual valorizaria seu passado e memória. Segundo informações divulgadas no site da CDURP, entre os principais elementos descritivos sobre a Operação Urbana, está o item "valorização do patrimônio material, histórico e cultural" ${ }^{\text {"72 }}$. O relato sobre a definição do tópico aponta que, ao descobrirem achados arqueológicos na região durante as obras iniciais, criou-se o "Circuito Histórico e Arqueológico da Herança Africana", o qual seria construído coletivamente por um Grupo de Trabalho Curatorial $^{73}$. O roteiro, com marcos da cultura afro-brasileiras na Região Portuária,

70 A Internacional Situacionista, grupo ao qual Guy Debord era parte, propunha ideias contra a "espetacularização das cidades". Suas ideias serão aprofundadas no capítulo 3.

71 "Cabe ainda ao governo local a promoção interna à cidade para dotar seus habitantes de "patriotismo cívico", de sentido de pertencimento, de vontade coletiva de participação e de confiança e crença no futuro da urbe. Esta promoção interna deve apoiar-se em obras e serviços visíveis, tanto os que têm um caráter monumental ou simbólico como os dirigidos a melhorar a qualidade dos espaços públicos e o bem-estar da população.” (BORJA, CASTELLS, 1996, p.160)

$72 \mathrm{http} / / /$ www.portomaravilha.com.br/portomaravilha

73 O grupo deveria também discutir diretrizes para a implementação de políticas de valorização da memória e proteção do patrimônio cultural http://www.portomaravilha.com.br/circuito 
seria composto por seis pontos: Cais do Valongo e Cais da Imperatriz, Pedra do Sal, Jardim Suspenso do Valongo, Largo do Depósito, Cemitério Pretos Novos, Centro Cultural José Bonifácio.

Apesar do circuito apresentar intenções de reconhecimento da diversidade cultural brasileira, o contexto contaria também com suas contradições. Enquanto o Cais do Valongo tornava-se candidato a Patrimônio da Humanidade da $\mathrm{UNESCO}^{74}$ - fato que, se concretizado, seria uma importante conquista para o local ${ }^{75}$, provavelmente contribuindo para os investimentos em sua manutenção -, o Instituto Pretos Novos (IPN) - considerado o maior cemitério de escravos do continente americano -, ameaçava fechar por inviabilidade financeira. Ao considerarmos, ainda, a diferença de investimento empregados nos museus da Praça Mauá (Museu do Amanhã e Museu de Arte do Rio) em contraponto aos locais do roteiro e outros locais da região considerados culturais, mostra-se evidente a escolha de prioridades, frente à estratégia adotada para o projeto do espaço. Segundo reportagem do Jornal Estadão de abril de $2017^{76}$, em auditoria da CDURP no Porto Maravilha, realizada pela nova gestão municipal ${ }^{77}$ no primeiro semestre de 2017, constatou-se que o Museu do Amanhã e o MAR teriam recebido $75 \%$ de toda a verba de fomento da cultura da região ${ }^{78}$. A fala do ex-prefeito Eduardo Paes cedida à reportagem do jornal sobre a distribuição da verba cultural, demonstra o foco da lógica adotada: “A decisão da administração anterior foi no sentido de criar dois ícones que permitissem a valorização da região e fossem âncoras do processo de revitalização - como o são"79.

74 Candidatura proposta a partir de dossiê elaborado pelo Instituto do Patrimônio Histórico Artístico e Nacional (Iphan) e pela Prefeitura do Rio de Janeiro em 2013. O título foi conquistado em julho de 2017.

75 Como aponta o IPHAN, a entrada na lista do Patrimônio Mundial "representará o reconhecimento do seu valor universal excepcional, como memória da violência contra a humanidade representada pela escravidão, e de resistência, liberdade e herança, fortalecendo as responsabilidades históricas, não só do Estado brasileiro, como de todos os países membros da UNESCO. É, ainda, o reconhecimento da inestimável contribuição dos africanos e seus descendentes à formação e desenvolvimento cultural, econômico e social do Brasil e do continente americano". Ver: http://portal.iphan.gov.br/noticias/detalhes/3489/cais-do-valongo-e-candidato-a-patrimonio-dahumanidade

76 Fonte: http://brasil.estadao.com.br/noticias/rio-de-janeiro,dinheiro-de-obra-em-favela-foi-paramuseu-do-amanha, 70001752056

77 Em janeiro de 2017, Marcelo Crivella, do PRB, tomou posse como novo prefeito da cidade. 78 A operação financeira estabelecida previa que $3 \%$ da venda das CEPACS (a qual teria rendido cerca de 3,5 bilhões de Reais) fossem aplicadas no fomento da cultura da região.

79Fonte: http://brasil.estadao.com.br/noticias/rio-de-janeiro,dinheiro-de-obra-em-favela-foi-paramuseu-do-amanha,70001752056 
Como resume Jacques, os equipamentos culturais, as franquias de museus e suas arquiteturas monumentais seriam as maiores atratoras usadas por tal lógica, criando cidades cada vez mais espetaculares, que visariam exclusivamente a indústria do turismo. Neste contexto, a cultura "serviria" como acesso à rede global que esta tanto almejaria pertencer. No caso das cidades-mercadoria, a cultura não manteria as particularidades locais, uma vez que o "processo das redes globalizadas", sob a vigência de um modelo internacional homogeneizador, demanda que suas "filiais" atendam a um determinado padrão mundial imposto pelos financiadores multinacionais dos projetos da chamada "revitalização urbana". Sendo assim, enquanto os dois grandes museus responderiam a tais demandas internacionais, o Instituto Pretos Novos não parecia atrativo aos investimentos por não serem considerados "âncora do processo de revitalização" - por mais que o cemitério seja extremamente representativo do patrimônio material, histórico e cultural da região, da cultura afro-brasileira e da história da cidade.

Para além das colocações sobre investimentos financeiros em cultura, mostra-se também simbólico o fato de que a mesma gestão que elaborou um roteiro para a valorização da história africana da região - nos quais cada ponto remeteria "a uma dimensão da vida dos africanos e seus descendentes na Região Portuária”, segundo o site da CDURP $^{80}$-, tenha também proposto tantas remoções no Morro da Providência, supostamente a primeira favela da cidade. Como relata o morador Cosme Vinícius Felippsen (apud FAULHABER \& AZEVEDO, 2015), “desde 2009, começou o boato da remoção, no contexto das obras do Porto Maravilha. Eles falaram que precisavam tirar 832 casas para alargamento de vias, melhorar o visual do lugar" (FAULHABER \& AZEVEDO, 2015, p.96). O argumento da prefeitura seria que 317 casas estariam no caminho do projeto desenvolvido para o Morar Carioca $^{81}$ e que 515 das moradias estariam em área de risco. Frente a tal ameaça,

80 Fonte: http://www.portomaravilha.com.br/circuito

81 O Morar Carioca, programa de urbanização de favelas na então gestão municipal, era apresentado em 2010 como o peça-chave do legado social dos Jogos Olímpicos de 2016. O projeto pretendia-se como o programa mais abrangente de urbanização de favelas da história da cidade que, com um orçamento de R \$8bilhões, iria integrar 815 favelas à chamada "cidade formal" até 2020. Incluía-se entre as obras, melhorias de saneamento básico, instalações de esgoto, iluminação de vias públicas, asfaltamento de ruas e calçadas, construção de espaços públicos e áreas de recreação, melhorias de transporte, estabilização de moradias e construção de centros de serviços sociais. Dos 40 escritórios de arquitetura aprovados por concurso da prefeitura (em parceria com o IAB) em 2012, apenas 10 teriam sido contratados efetivamente. Até outubro de 2015, apenas três projetos haviam sido concluídos. Ver: http://rioonwatch.org.br/?p=12410 
moradores organizaram-se através de comissão para barrar as remoções. Além de irem à justiça para paralisar as obras, contrataram especialistas para realizarem um contralaudo sobre as áreas de risco: segundo o estudo realizado, a maior parte das casas apontadas pela prefeitura não sofria risco de deslizamento ou de qualquer outra natureza. Cerca de duzentas famílias foram removidas do Morro da Providência até $2014^{82}$ (FAULHABER \& AZEVEDO, 2015).

Da mesma forma, é contraditório notar que a gestão que propunha um projeto de integração de moradores antigos ao "novo porto", não tenha consultado as prioridades locais frente à instalação do teleférico na favela ${ }^{83}$, como apontam relatos de moradores ${ }^{84}$. Para além dos projetos no Morro da Providência, cabe pontuar que no Morro do Pinto (também parte da região portuária), a mesma auditoria supracitada constatou que 112,3 milhões de reais, que seriam destinados a obras de infraestrutura no local, foram desviados para acelerar as obras do Museu do Amanhã, em $2012^{85}$, para a ocasião das Olimpíadas.

As decisões projetuais na Operação Urbana pareciam voltar-se para a construção de um cenário a ser visitado por turistas. Os discursos utilizados e a linguagem adotada seriam mais uma tentativa de construir uma representação para a cidade que correspondesse aos atributos da rede internacional. A partir do projeto pensado para a região portuária, a "Cidade Maravilhosa" se mostraria renovada, com grandes ícones arquitetônicos e atrações, um centro de negócios com empreendimentos projetados por grandes empresas globais. Além de todo o potencial de investimento que se pretendia divulgar através destes itens, seria também possível demonstrar uma cidade com caráter inovador, sustentável, cultural e, ainda, com consciência social e patrimonial. Um Rio de Janeiro maravilhoso e espetacular, pronto para lançar-se no concorrido mercado internacional.

82 Segundo o censo do IBGE de 2010, a Providência tem cerca de cinco mil moradores. 83 O teleférico da Providência foi parte do projeto de urbanização do Programa Morar Carioca, concluído em 2014, teria custado R 75 milhões (o custo total do Morar Carioca na região teria sido de R\$ 163 milhões). Fonte: http://agenciabrasil.ebc.com.br/geral/noticia/2014-03/teleferico-daprovidencia-esta-virando-um-telepombo-denunciam-moradores

84 ver: http://www.anf.org.br/e-o-teleferico-da-providencia/

85 Fonte: $\mathrm{http}$ //brasil.estadao.com.br/noticias/rio-de-janeiro,dinheiro-de-obra-em-favela-foi-paramuseu-do-amanha, 70001752056 


\section{4 \\ O Rio de Janeiro vivido: \\ olhares sobre a cidade a partir da Favela Nova Holanda}

Representações sobre o espaço vivido da cidade nos apresentam um Rio de Janeiro distinto do imaginado pelas campanhas publicitárias e propostas no projeto para o "Porto Maravilha". Um olhar sobre vivências e os entendimentos locais sobre usos do espaço em diferentes bairros da cidade nos mostraram uma cidade diversa, com características locais próprias a cada bairro, sendo estas, profundamente distintas entre si. Como aponta Ana Fani Carlos (2001):

A identidade na metrópole se constrói a partir do sujeito no plano da vida imediata, aquela do bairro, no lugar onde esta se desenvolve por meio dos modos de habitar, nas relações de vizinhança, pelo uso do espaço que marca as formas de sociabilidade, de reconhecimento, produzindo os referenciais que dão suporte à memória, porque sustentam a vida de relações e criam a identidade. A relação entre a organização do tempo na vida cotidiana e os modos de uso do espaço para a realização da vida contempla as possibilidades da invenção e da espontaneidade que tem lugar na metrópole. São os momentos das apropriações possíveis que privilegiam o uso em detrimento da troca, nascimento comum de desejos de mudar a vida ou intensificála e que se colocam como possibilidades de existência dos espaços do encontro, da troca, da informação, dos jogos, do divertimento, do prazer. (CARLOS, 2001, p.279)

Como contraponto às representações expostas no capítulo 3, proponho aqui apontar olhares sobre o entendimento do espaço urbano carioca a partir das representações construídas por moradores da Nova Holanda, favela que compõe o Complexo da Maré. Pretendo, neste capítulo, discutir a pluralidade do Rio de Janeiro a partir dos espaços de representação construídos por quem lá vive.

A escolha da Nova Holanda entre tantos outros locais da cidade para pontuar a discussão, não foi aleatória. Já expus na introdução deste trabalho a importância de olharmos a cidade a partir das favelas e de incluí-las na agenda da cidade através de suas potencialidades (BARBOSA, 2014). A escolha da Maré e de uma de suas favelas, especificamente, se deu por características próprias a tais espaços que contribuem para o debate colocado aqui. Entre tais questões, pode-se apontar tanto a sua importância dimensional e geográfica para o Rio de Janeiro como também a sua história de luta, intrinsecamente ligada ao seu próprio surgimento. A seguir, 
contextualizo tais questões, partindo então para três olhares de autorrepresentação construídos por moradores da Maré sobre seu espaço e o cotidiano local - olhares estes que demonstram singularidades locais e entendimentos/desejos sobre a ideia de cidade.

\section{1 O Complexo da Maré}

Pode-se dizer que o Complexo da Maré faz parte do imaginário carioca. Um dos motivos para tanto, seria relativo a seus dados demográficos: segundo o Censo Maré 2000, desenvolvido pelo CEASM, o complexo é o maior conjunto de favelas do Brasil, sendo habitado por 132.176 moradores no ano da pesquisa, o que representaria $2,26 \%$ da população do município carioca.

A distribuição da população local se dá entre dezesseis favelas - ordenadas aqui por ano de ocupação (JACQUES, 2002): Morro do Timbau (1940), Baixa do Sapateiro (1947), Conjunto Marcílio Dias (1948), Parque Maré (1953), Roquete Pinto (1955), Rubens Vaz (1961), Parque União (1961), Nova Holanda (1962), Praia de Ramos (1962), Conjunto Esperança (1982), Vila do João (1982), Vila Pinheiros (1989), Conjunto Pinheiros (1989), Bento Ribeiro Dantas (1992), Nova Maré (1996), Salsa e Merengue (2000). No total, haveriam 38.273 domicílios, os quais teriam uma média de 3,55 habitantes por domicílio.

Para além da questão dimensional do complexo, sua localização geográfica também contribui para que a Maré se destaque no imaginário da cidade: parte da região da Leopoldina, Zona Norte do Rio de Janeiro, o complexo é situado entre as três principais vias da cidade - a Linha Vermelha, Linha Amarela e Avenida Brasil. Necessariamente, quem chega ao Rio de Janeiro e se direciona à Zona Sul ou Zona Norte, passará pelo complexo de favelas, assim como quem utiliza o Aeroporto Internacional do Rio de Janeiro ou vai para a Universidade Federal do Rio de Janeiro.

A representação endereçada ao Complexo da Maré é, muitas vezes, a de lócus de violência e miséria, dominado pelo tráfico de drogas e a marginalidade. Como apontado anteriormente, a representação que se constrói sobre as favelas não só foi usada historicamente como aparato ideológico para afastamentos e destruição de 
modos de vida não condizentes com valores pretendidos pelo poder hegemônico da cidade, como também, até hoje, contribui para a negação do que foge do padrão estético e social do considerado "civilizado". O campo simbólico das representações dos espaços das favelas como espaços da violência e da anticivilidade - massivamente reproduzidos nas mídias - faz com que estejam presentes na agenda da cidade a partir do caráter de "ausência" (BARBOSA, 2014). Neste contexto, políticas de militarização e repressão policial passam a ser justificadas como caminho de uma "intervenção necessária". Da mesma forma, políticas e intervenções urbanas que não atendem às necessidades mais urgentes ou que servem ao "espetáculo urbano" - tal como no caso do teleférico do Complexo do Alemão ou da passarela da Rocinha -, viram prioridade para os órgãos públicos ${ }^{86}$ (CAVALCANTI, 2013). No caso da Maré, a "barreira acústica", inaugurada em 2010, é emblemática sobre tal questão.

O projeto construiu um "muro" de sete quilômetros separando a Linha Vermelha do Complexo da Maré, local de principal acesso ao aeroporto internacional da cidade. Apesar de a prefeitura afirmar que a estrutura seria uma barreira para proteger os moradores do barulho dos carros e de possíveis atropelamentos, muitos moradores veem a intervenção física como uma forma de esconder as favelas da visão dos turistas que chegam à cidade. Seja por um objetivo ou outro, é curioso notar como, ao escolher elementos gráficos para compor visualmente a superfície da barreira acústica, elegeu-se preenchê-la com silhuetas de ícones do cartão postal "oficial" do Rio de Janeiro, os quais remeteriam ao famoso imaginário da "Cidade Maravilhosa" 87 .

86 Mariana Cavalcanti (2013) aponta que intervenções em larga escala do PAC e das UPPs articulariam uma "gramática de controle social das favelas", a qual chama de PACificação (Cavalcanti, 2013, p.197). As intervenções do programa teriam mostrado uma recorrente busca, na realidade, por invisibilizar as áreas da cidade que não se quer mostrar para os turistas e investidores (tais como as favelas e periferias). O desejo latente pela imagem de "um Rio integrado" torna-se literal em intervenções como a passarela da Rocinha ou os teleféricos do Alemão e da Providência: afinal seriam a materialização do discurso ao se construir conexões físicas entre a favela e a dita "cidade formal". O artigo de Cavalcanti argumenta como a dimensão e o caráter formal dos instrumentos pretendem deixar evidente a intervenção do Estado no local ao mesmo tempo em que ofuscam a favela em si, transformando-as em cenários. O que sobressairia na paisagem seria $\mathrm{o}$ espetáculo da "integração" entre os espaços. Ao mesmo tempo que inviabilizariam também a execução de projetos mais urgentes para tais locais.

87 Cabe pontuar também que, durante os Jogos Olímpicos sediados na cidade, adesivos vinílicos opacos com a identidade visual do evento foram aplicados à barreira acústica, cobrindo integralmente a superfície da estrutura e deixando o outro lado ainda menos visível. 


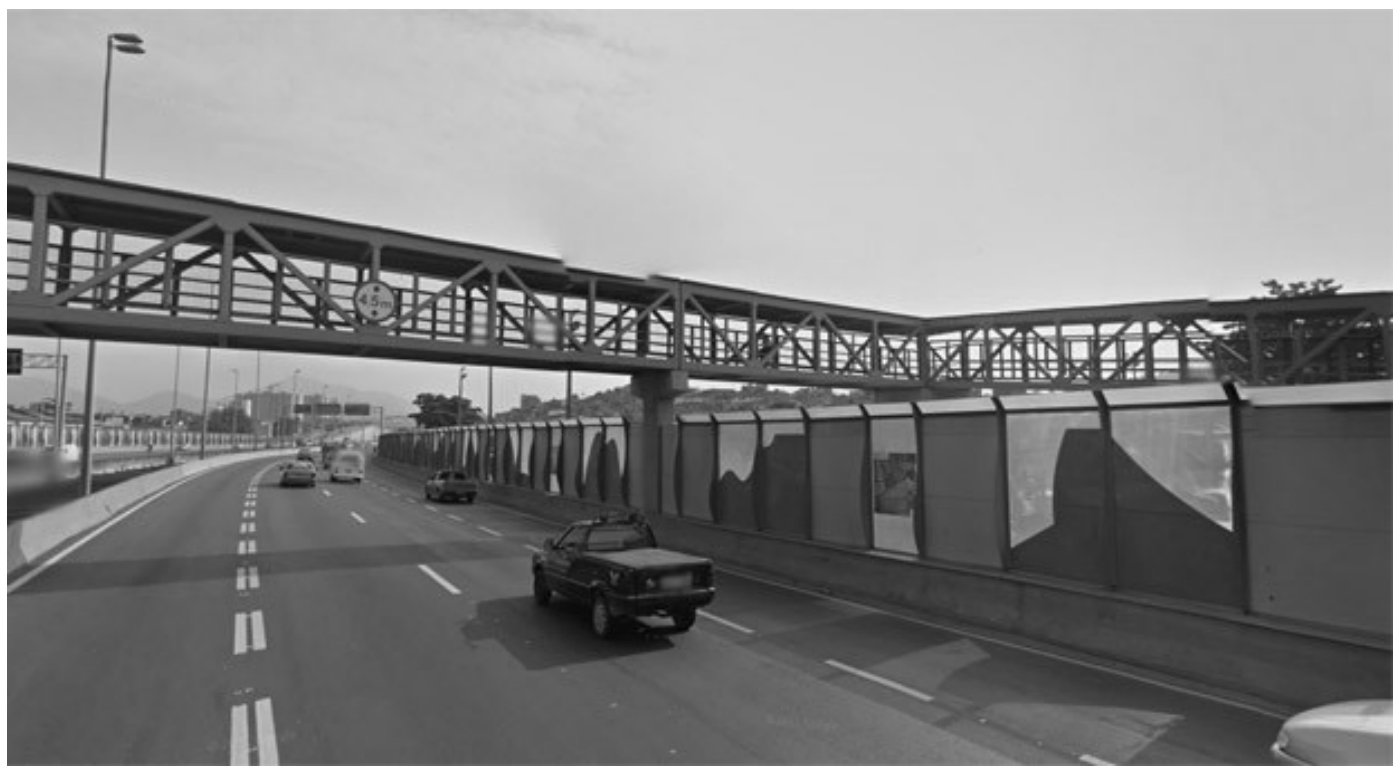

Figura 14 - Imagem da barreira na Linha Vermelha. Fonte: Google Street View.

Jailson de Souza e Silva (2001) aborda a questão das prioridades de investimentos ao analisar o Índice de Qualidade de vida urbana da região administrativa da Maré $(\text { XXX R.A })^{88}$, relacionando-o aos indicadores culturais e econômicos locais ${ }^{89}$. Segundo Silva:

A contradição entre os indicadores urbanos ${ }^{90}$, por um lado, e os sócio-educacionais e econômicos, por outro, decorre do tipo de intervenção urbana realizada na Maré, nas últimas décadas: o projeto do poder público tinha como pressuposto uma visão restrita de urbano, onde se privilegiava uma intervenção física, centrada em ações de engenharia, ignorando-se a necessidade de produção de uma política social. Essa política - voltada para a geração de renda, para o estímulo à participação da população local na resolução de suas demandas e o investimento em iniciativas culturais e educacionais - nunca se fez presente na urbanização, mesmo levandose em conta as três instâncias do poder público que atuaram na Maré. E, provavelmente, essa postura também se expressou nas intervenções urbanísticas realizadas nos outros espaços favelados cariocas - como demonstram seus indicadores sociais. (SILVA, 2001, p.82)

Para além de intervenções urbanas pontuais, o Complexo da Maré é considerado, em si, um dos maiores "laboratório urbanos de habitação popular" do país, um lugar onde inúmeras experiências habitacionais foram implementadas (JACQUES,

88 Relativamente bem posicionada, ela estaria na décima primeira posição em relação ao universo de vinte e oito grupos de favelas.

89 Os dados apontam que o percentual de moradores com títulos de graduação não atingiria a margem de $1 \%$ do total de habitantes, assim como os rendimentos de menos de um terço do total de habitantes seria maior do que dois salários mínimos ao mês.

90 Em nota, o autor esclarece que define no caso urbanização como "processo de mudanças na estrutura física do espaço, além da implantação de determinados serviços e mobiliários urbanos: asfalto, água, esgoto, praças e telefonia. 
2002). Dentre as dezesseis favelas do Complexo, dez são espaços construídos ou reconstruídos pelo poder público, o qual faz com que sua conformação seja composta por diferentes morfologias urbanas e tipologias arquitetônicas. Como descreve Jacques (2002), ao andar através das favelas do complexo, vê-se desde a malha "da favela labiríntica de morro" aos planos cartesianos dos conjuntos habitacionais modernistas. "Vai-se do padrão mais informal ao mais formal, que acaba se informalizando também" (JACQUES, 2002)

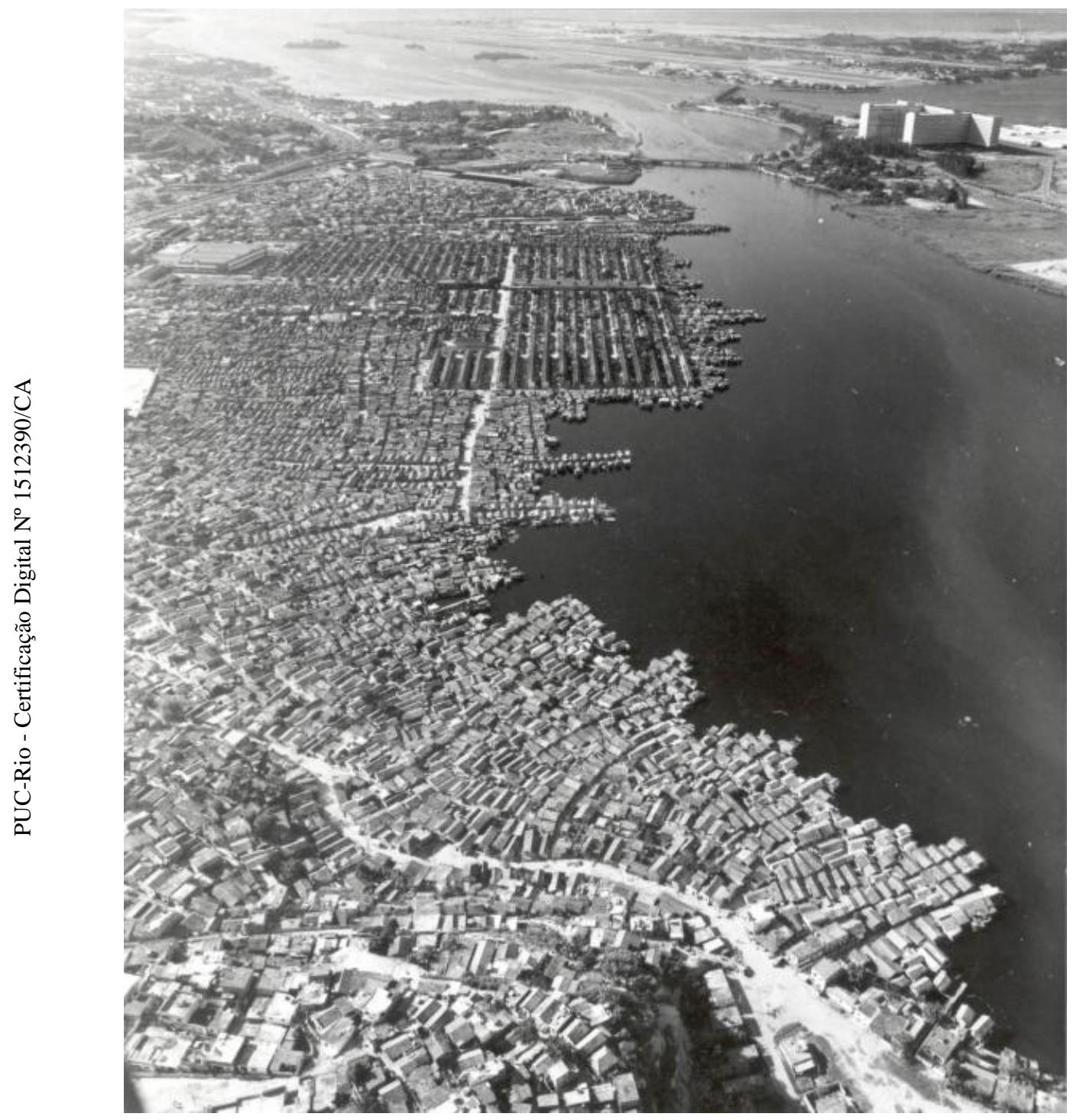

Figura 15 - Vista aérea do Complexo da Maré na década de 1970/1980. Fonte: Museu da Maré.

A partir dos dados colocados até aqui, é possível pontuar que a escolha do complexo para a pesquisa se deu tanto pela sua dimensão física e importância simbólica atual para a cidade, como pela diversidade espacial existente, colocada pelos diferentes tipos de urbanização e por suas características socioeconômicas. Porém, para além 
de tais questões, a Maré apresenta também uma outra forte peculiaridade: o complexo é reconhecido historicamente como espaço de resistência e luta, não só pelas características do terreno onde as habitações eram construídas pelos moradores - solo pantanoso, inundável e com marés -, mas também pelas constantes ameaças de remoção que seus habitantes recebiam.

A Maré surgiu na década de 1940, no Morro do Timbau, a única área que seria seca, em meio ao manguezal da região ${ }^{91}$. Com a construção da Avenida Brasil a partir de 1939, a ocupação da região conhecida hoje como Maré começa a ser consolidada ${ }^{92}$. Como a região da Leopoldina sofria com a especulação imobiliária, a qual elevava o preço de seus terrenos, a opção de moradia para os trabalhadores era, muitas vezes, instalar-se nas áreas alagadiças que beiravam a Baía de Guanabara (RIBEIRO et al., 2012).

As palafitas, tipo de construção possível em tal tipo de terreno, passou a fazer parte da configuração de algumas das favelas do complexo durante algumas décadas. $\mathrm{O}$ imaginário que se construiria sobre a região - ainda reproduzido hoje - seria pautado por tais moradias, as quais representariam a precária condição de vida a que parcela significativa dos moradores vivia (JACQUES, 2002; SILVA, 2001; SOUZA SILVA, 2012). Jacques, ao falar sobre o processo construtivo das palafitas, relaciona as dificuldades vividas com a capacidade dos moradores de resistência, resiliência e união:

O passado próximo da Maré é repleto de instabilidades, de constante transformação e de inúmeras reconstruções; um eterno vai-e-vem de materiais de construção que pode ser relacionado com o próprio movimento das águas(...).Parece que a população ali aprendeu de fato com as marés, observando seu movimento constante, sua mutação contínua, e assim os moradores da Maré conservam ainda hoje essa sabedoria do equilíbrio instável dos antigos marujos das palafitas. (JACQUES, 2002, p.22)

91 Na época, logo após a Revolução de 1930 e com a implementação do projeto industrial do país, o Rio de Janeiro passava por um processo de descentralização das atividades do setor. Neste contexto, empresas de médio porte instalavam-se em São Cristóvão e no subúrbio, o qual começa a ser servido pelo trem. Consequentemente, parcelas da população também foram atraídas para tais áreas, onde poderiam viver próximo ao trabalho.

92 Uma vez que, além de serem feitos aterramentos e vias de acesso para a área, a obra da avenida também representaria a possibilidade de trabalho na construção do entorno e nas instalações dos empreendimentos que iam surgindo na localidade - tal como a Refinaria de Manguinhos (1954) e a Cidade Universitária da UFRJ. 
A "força de união", citada por Jacques (2002), se mostrou presente ao longo da história da Maré, principalmente em relação às imposições externas que buscavam reestruturar o espaço do complexo. Pode-se dizer que a configuração urbana da região passou por considerável mudança até o período atual. Entre a criação do Morro do Timbau e o início da década de 1980, haviam seis favelas na Maré, porém, com a implantação do Projeto Rio, em 1979, a região sofreria uma grande transformação (SOUZA SILVA, 2012). O projeto, desenvolvido durante os últimos anos da ditadura militar, previa que algumas favelas do complexo fossem removidas e que a população fosse transferida para conjuntos habitacionais, havendo também a urbanização das favelas remanescentes e o saneamento do entorno da Baía de Guanabara.

A postura autoritária da definição e das implantações do projeto, geraram não só fortes críticas, mas também resistência de grupos comunitários locais, os quais conseguiram que a ideia de remoção fosse descartada e as propostas do projeto repensadas. A principal reivindicação da representação popular era que as palafitas fossem erradicadas e que seus moradores pudessem ser transferidos para outros locais na região (SOUZA SILVA, 2012). E assim foi feito. Tal conquista seria representativa para o movimento de organização dos moradores. Na oportunidade, as lideranças comunitárias locais criaram ainda a Comissão de Defesa das Favelas da Maré (Codefam), em prol de interlocução com o governo federal para que os interesses dos moradores fossem atendidos.

Eliana Souza Silva (2012) aponta que nos anos seguintes ao Projeto Rio, a Maré passou a receber equipamentos e serviços públicos ${ }^{93}$. Sobre as ofertas que surgiam ao longo do ano, Souza Silva (2012) aponta para a importância da organização dos moradores na conquista de equipamentos públicos:

A existência de serviços públicos na Maré explica-se, historicamente, pelos investimentos feitos no âmbito do Projeto Rio, no final da década de 1970 e pela forte articulação do movimento comunitário local, que conseguiu criar uma razoável ação integrada, a partir dos anos 1980. (SOUZA SILVA, 2012, p. 66)

93 Tais como oferta de energia e água, varredura de ruas e esgoto sanitário instalado, calçamento de todas as ruas, serviço de telefonia, dezesseis escolas de ensino fundamental e duas de ensino médio, creches, sete postos de saúde, posto de atendimento da COMLURB e Cedae, a XXX Região Administrativa, um Centro Estadual de Defesa da Cidadania, uma Lona Cultural, uma Unidade de Pronto Atendimento, dois postos simplificados da Fundação Leão XIII93 e a Vila Olímpica da Maré. (SOUZA SILVA, 2012, p.65-66) 
Ainda segundo Eliana Souza Silva (2012), pela primeira vez em 1984, uma das favela da Maré conseguiu eleger pelo voto um morador para a Associação de Moradores $^{94}$. A Favela Nova Holanda passaria a ser gerida pela Chapa Rosa, presidida pela própria Eliana, um simbolismo não só do protagonismo feminino no processo de lutas comunitárias, como também da organização dos moradores para a melhoria de condições locais. A mobilização de moradores seria, inclusive, característica apontada como própria da Nova Holanda, favela da qual decidi partir para discutir a cidade do Rio de Janeiro. Cabe aqui contextualizar a origem da Nova Holanda e alguns dados históricos desde sua criação.

\subsection{1}

\section{A Favela Nova Holanda}

A Nova Holanda surgiu na década de 1960 como resultado do Programa de Remoção de Favelas do governador Carlos Lacerda. Profundamente distinta das favelas ao redor, a Nova Holanda foi construída para servir como um dos três Centros de Habitação Provisória (CHP) que o programa do Estado projetava fazer.

O local foi pensado para ser temporário, funcionando como uma espécie de "triagem" na qual moradores passariam antes de serem realocados em conjuntos habitacionais. A lógica dos CHPs era representativa de uma política habitacional repressiva que impunha que seus habitantes deveriam ter uma "temporada educativa" no espaço para "adaptarem-se" à vida urbana (JACQUES, 2002).

Pretendia-se que os moradores aprendessem novos hábitos de higiene, novas formas de relacionamentos sociais e convivência comunitária: estabelecia-se horários para saída e chegada, proibia-se qualquer alteração nas casas e até mesmo controlava-se as brigas familiares. A administração e fiscalização de convivência ficava a cargo da Fundação Leão XIII1 e de um posto da Polícia Militar. Segundo Eliana Souza Silva (1995), a política utilizada na Nova Holanda era idêntica à implementada em alguns Parques Proletários na década de 1970, tal como aponta Leeds:

94 Até então, a presidência das associações eram escolhidos pela Fundação Leão XIII, órgão do Estado ligado à Secretaria de Ação Social 
A autoridade da administração (dos Parques Proletários) era absoluta. Todos os moradores tinham cartão de identificação que apresentavam ao guarda noturno, encarregado de fechar os portões às 22 horas. Às 21 horas, o administrador falava por auto-falante, comentando os acontecimentos do dia, servindo-se da ocasião para pregar lições de moral que julgasse necessárias (LEEDS apud SOUZA SILVA, p.78)

Após estarem "civilizados", dentro de parâmetros estabelecidos através da ideia de civilidade de um habitante pertencente à classe média, o "favelado" estaria apto a morar em uma casa de alvenaria ou um apartamento (RIBEIRO et al., 2012).

O controle e a imposição de noções sobre "civilidade", dava-se também através da estrutura urbana e arquitetônica do espaço. A configuração urbana era composta pela regularidade e ortogonalidade dos conjuntos habitacionais modernistas (JACQUES, 2002). As casas, organizadas em lotes de cinco metros de largura e dez metros de comprimento, eram de madeira e poderiam ter duas configurações, sendo uma de "casas baixas" e outra de dois andares. Todas as unidades dispunham de uma sala, dois quartos, uma cozinha, um banheiro, um quintal e uma varanda (SOUZA SILVA, 1995).

O espaço possuía estrutura construída para esgotamento sanitário, água e energia elétrica, porém, projetada para atender a um número inferior de pessoas ao existente. O caráter provisório e de trânsito a que se pretendia o CHP implicou em uma infraestrutura sem condições para utilização plena. O esgoto, em pouco tempo, transbordava, assim como criava "valas" junto a área projetada para escoamento da chuva (contaminando os canais). O abastecimento de água, também regular no inicio, passou a ser artigo raro nas residências. A energia elétrica, por sua vez, além de não suprir o crescimento da demanda, sofreu com a falta de manutenção (RIBEIRO et al., 2012).

Como aponta Souza Silva (1995), os moradores, frente à escassez frequente, procuravam alternativas de melhorias, tal como desentupir eles mesmos os esgotos, ou buscar formas de distribuição de água (fosse pela venda do recurso q chegava a algumas casas ou por sua distribuição gratuita). Porém, em muitos aspectos, a falta 
de confiança existente entre os moradores ainda dificultava os acertos locais, tal como na busca pela melhoria na energia elétrica ${ }^{95}$.

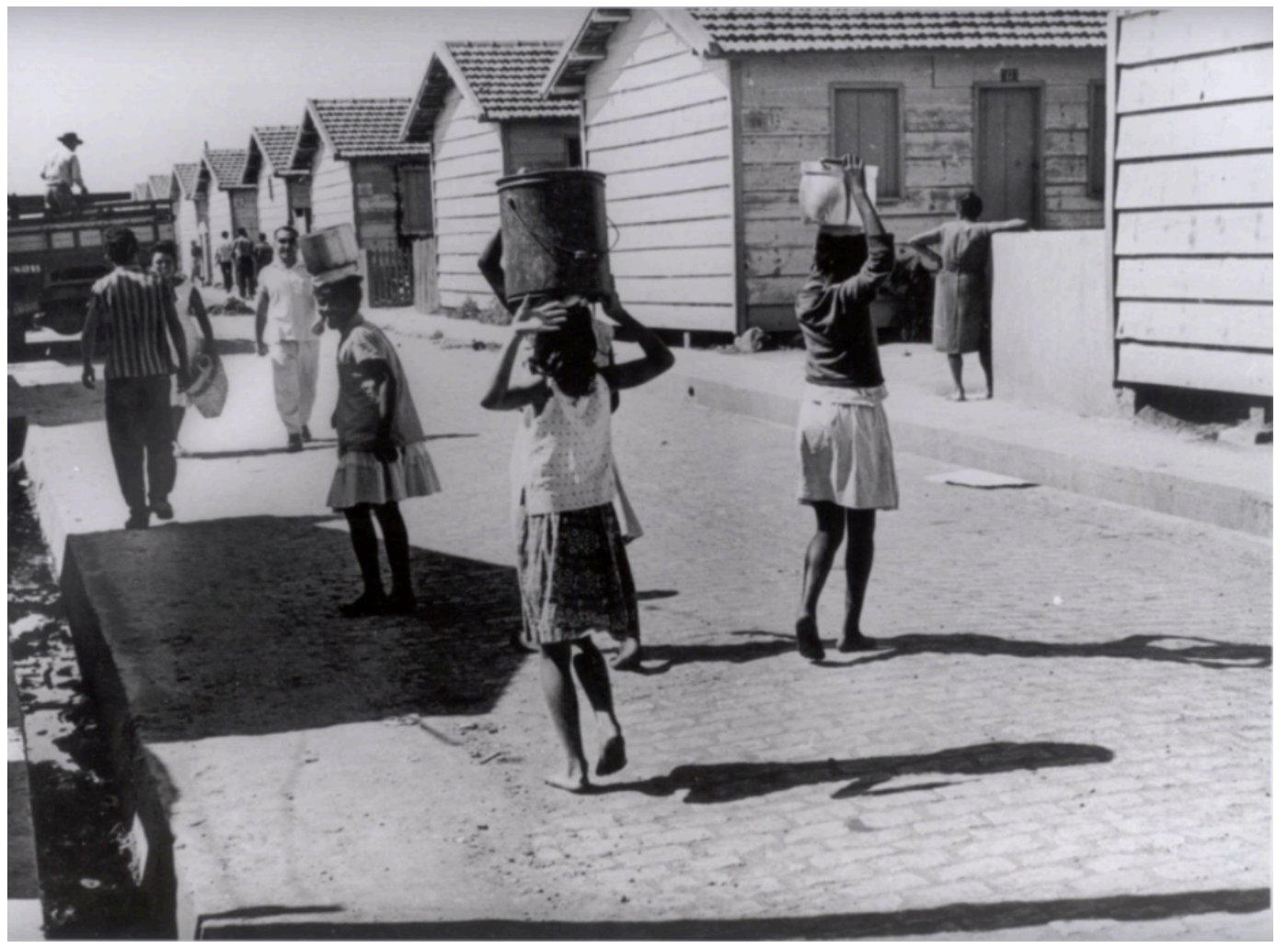

Figura 16 - A Favela Nova Holanda na década de 1970. Fonte: Museu da Maré.

A dificuldade de criação de vínculos de confiança e parceria entre as pessoas seria fruto da maneira como a Nova Holanda fora habitada (SOUZA SILVA, 1995). Seus novos moradores eram oriundos de diferentes favelas do Rio de Janeiro ${ }^{96}$, o que resultava na perda, não só de suas redes de sociabilidade, como, muitas vezes, também dos laços de afetividade na família por conta da separação de entes nas remoções. Somado a tais questões, a mudança nos hábitos, o distanciamento do local de trabalho, assim como a perda da identidade construída através da história de luta e resistência nas favelas de onde haviam sido retiradas, faziam com que a

95 Segundo Ribeiro et al. (2012), alguns moradores buscaram organizar-se através da Comissão de Luz, a qual procurava criar cotas para resolver problemas de fiação e manutenção do sistema elétrico. Porém, a comissão encontrava consideráveis obstáculos em seu trabalho, não só pela falta de recursos de muitos moradores, mas também pela dificuldade de organização social entre os vizinhos nas condições existentes (RIBEIRO et al, 2012).

96 Sendo elas: Favela do Esqueleto (Maracanã, Zona Norte), Morro da Formiga (Tijuca, Zona Norte), Morro do Querosene (Centro), Praia do Pinto (Leblon, Zona Sul) e de Macedo Sobrinho (Humaitá, Zona Sul). Em menor número, o então CHP recebeu também moradores de algumas outras favelas da Zona Norte da cidade, tal como de uma pequena favela em Bonsucesso e da Favela Taborari (parte integrante da Favela Brás de Pina). 
pobreza e a dificuldade de integração entre a vizinhança se agravasse ${ }^{97}$. Ainda segundo Ribeiro et al., “(...) além de ferir o direito elementar, inerente a todo cidadão, de optar pelo próprio espaço, o processo de remoção e civilização destruiu o ‘equilíbrio' econômico construído por cada família e aniquilou suas realidades sociais" (RIBEIRO et al., 2012, p.89). No final da década de 1970 e início de 1980, porém, o espaço passou por um período de grande luta pela melhora das condições de vida local e pelo fim da tutela da Fundação Leão XIII.

Cabe aqui contextualizar que o debate em âmbito global que acontecia sobre assentamentos humanos começava a transformar a visão da sociedade e das políticas locais em relação aos espaços das favelas. A Conferência organizada pelas Nações Unidas, em 1976 em Vancouver, que criou a Agenda Habitat, entre outros debates que criticavam programas de remoção de favelas, contribuíram para que a urbanização ganhasse maior respaldo da sociedade civil do que as remoções. $\mathrm{O}$ debate deflagrado estava também contribuindo para que os moradores de favelas as vissem como parte integrante da cidade e a si mesmos como habitantes legítimos e não mais como "ocupação" ou "população provisória" (RIBEIRO et al., 2012). E assim foi também na Favela Nova Holanda.

$\mathrm{Na}$ época, a Nova Holanda sofria com a falta de postos de saúde e escolas, além da insegurança em relação ao título de propriedade da casa. O surgimento de um Posto de Saúde Comunitário, composto por médicos sanitaristas, juntamente com o contexto supracitado, começaria a estimular a discussão interna sobre direitos básicos e pertencimento à cidade, o que seria fundamental para que os moradores reivindicassem mudanças sobre as ausências até então existentes. Sobre o posto de saúde, vale destacar que:

Tratavam-se de profissionais recém-formados que buscavam realizar um trabalho de atendimento médico, mas também de informação/esclarecimento acerca do tema "Saúde", numa tentativa de fazer política de uma forma diferente: aliando a questão profissional à opção ideológica, além do desejo de aproximação com o povo pobre e sua condição precária de vida nas favelas. (...). A tônica dada ao trabalho no posto

97 Importante salientar, ainda, a forma como a remoção havia sido feita, caracterizada como de extremo autoritarismo. Segundo Souza Silva (1995): "A forma pela qual as famílias eram comunicadas da remoção era bastante agressiva, sem qualquer diálogo ou discussão acerca do lugar ou mesmo das condições em que se encontrariam as novas áreas onde residiriam. Ao saber da remoção, arrumavam os pertences, que eram colocados em caminhões e transportados para os Centros de Habitação Provisória (CHP's). Muitas famílias esperavam às vezes até 24 horas para retirar a mudança (...)" (SOUZA SILVA, 1995, p.71). 
buscava, no período inicial, firmar uma atuação concreta a respeito do tema da saúde e, ao mesmo tempo, contribuir para a criação de grupos comunitários que pudessem lutar por necessidades básicas. Implicitamente, isso colocava a questão da briga por direitos negados à população da favela como condição para ter mais saúde. (RIBEIRO et al., 2012, p.91)

Dos encontros promovidos pelo "postinho", como era conhecido, foi criado o Grupo de Mulheres, em 1977, as quais engajaram-se na luta por melhores condições de vida para a Nova Holanda, a iniciar-se pela reivindicação por água potável. Para além do atendimento médico, buscavam também formar moradores para que pudessem tornar-se agentes de saúde ${ }^{98}$. Um outro ponto a se destacar sobre o posto diz respeito à definição das prioridades, as quais eram traçadas através de reuniões com os moradores realizadas na rua, uma experiência que promovia a participação direta da população nas discussões e escolhas.

Outros movimentos e acontecimentos somam-se ao posto de saúde da Nova Holanda como motivadores de organização local e conscientização sobre direitos ${ }^{99}$. Ribeiro et al. (2012) citam ainda o Projeto Rio, descrito acima como um outro motivador do fomento a uma "consciência crítica" na Nova Holanda. A Associação de Moradores construída a partir da Chapa Rosa, supracitada, teria sido um fator igualmente importante para o contexto que se conformava. Nomeada como Associação de Moradores e Amigos da Nova Holanda (AMANH), sua gestão teria contribuído para a construção de processos de luta por direitos sociais básicos ${ }^{100}$, assim como destacou-se também pela mobilização de moradores e de conscientização política ${ }^{101}$.

Para além de tais questões, o processo de redemocratização do país, com o fim do regime militar, iria também corroborar para a organização dos moradores da Nova Holanda, assim como em diferentes favelas da cidade, fomentando o associativismo e reivindicações estruturais (RIBEIRO et al., 2012). Pode-se dizer que:

no processo de mobilização, reuniões, assembleias, construção de reivindicações e pressão sobre o Estado, os moradores foram forjando uma identidade combativa e

98 Em 1981 a equipe possuía forte caráter plural, não só pela interdisciplinaridade dos profissionais, mas pela horizontalidade na qual se propunham a realizar as discussões, tendo médicos, psicólogos, sociólogos, enfermeiras, moradoras do Grupo de Mulheres, jovens e adolescentes em uma relação democrática.

99 Entre eles, a Igreja Católica da Nova Holanda e seu grupo jovens.

100 Tais como luz, água, asfalto, coleta de lixo, habitação e regulamentação das propriedades.

101 As assembleias realizadas na rua chegavam a reunir cerca de quinhentas pessoas. 
assumiram para si uma autorrepresentação positiva. Essa identificação foi importante, pois estabeleceu as bases para a rejeição de rótulos e estereótipos que lhes eram impingidos e que dificultavam bastante a vida. (RIBEIRO et al., 2012, p.107)

Neste contexto, a Nova Holanda, um local construído através de fragmentos de diferentes partes da cidade e onde o controle social ditava o cotidiano, passava a consolidar-se enquanto lugar de luta e de protagonismo social na construção do espaço.

\section{2.}

\section{Três olhares sobre a Nova Holanda}

Assim como na descrição sobre a época das palafitas, ainda hoje a representação difundida sobre a Maré é reproduzida como um espaço da violência, um lugar habitado por criminosos e pessoas tidas como marginais. Nas imagens de uma rápida pesquisa no Google com as palavras-chave "Complexo da Maré + Nova Holanda +Rio de Janeiro", vemos majoritariamente jovens homens negros armados, operações policiais e fotos de pessoas capturadas pela polícia. Por outro lado, porém, ao avançar pela pesquisa, surgem algumas fotografias de crianças brincando nas ruas, meninos soltando pipa nas lajes, assim como registros das casas. Tais imagens são de moradores da Maré que se propõem a mostrar o cotidiano local como forma de resistência às representações reproduzidas pela mídia, pelo Estado e, consequentemente, na sociedade. Elas mostram um Rio de Janeiro bem distinto da representação criada para a famosa "Cidade Maravilhosa". Revelam um espaço construído por seus moradores através de estratégias desenvolvidas para suprir lacunas na oferta de direitos fundamentais (BARBOSA, 2014).

Pode-se dizer que a mudança no caráter das imagens vistas em ferramentas como Google Image (assim como em exposições, revistas e outros meios de informação) decorreu-se de fatores como o maior acesso às ferramentas de tecnologia e informação, mas também - e consequentemente -, do crescimento do movimento de autorrepresentação presenciado em áreas periféricas e de favelas no Brasil, tal como abordado na introdução deste trabalho. 
No contexto da Nova Holanda, assim como de grande parte do Complexo da Maré, o "Imagens do Povo", projeto promovido pelo Observatório de Favelas ${ }^{102}$, contribuiria para a discussão sobre a autorrepresentação local. Criado em 2004, o projeto se propunha a ser um programa de formação de moradores de periferias e favelas em fotografia, partindo do questionamento sobre a democratização da informação. A fotografia seria uma ferramenta para discutir questões éticas, políticas e culturais. Ao registrarem seus espaços em cenas cotidianas, os fotógrafos do Imagens do Povo buscariam revelar as "possibilidades, vivências e riquezas múltiplas construídas no cotidiano pelos moradores da cidade e dos territórios populares, especialmente" (SOUZA, in: IMAGENS DO POVO, 2011, p.12), buscando assim transformar as condições que mantêm os favelados em posições subalternas na sociedade.

Apesar da pesquisa aqui desenvolvida não se basear especificamente na proposta do projeto, cabe destacar que os três fotógrafos entrevistados são formados pela escola de fotografia do Imagens do Povo. Suas imagens, as quais possuem linguagens próprias a cada um dos autores, têm em comum a proposta de construir olhares sobre o espaço da Maré que transformem a representação sobre o complexo - discurso que estaria alinhado às supracitadas colocações de Jaílson de Souza e das propostas iniciais do Imagens do Povo.

O surgimento de representações das ruas da Nova Holanda construídas pelo olhar do morador mostraria realidades locais que não poderiam ser imaginadas quando consideradas as representações majoritariamente vinculadas pela mídia. Para além de questionar estigmas, mostrariam práticas culturais criativas e ricas estratégias de construção do espaço - como apontado na introdução, a partir de Jorge Barbosa (2014).

102 O Observatório de Favelas é uma organização da sociedade civil, presentes na Maré. Entre as diferentes frentes de ação, é importante destacar aqui seu trabalho desenvolvido sobre a questão da representação de espaços populares. Entre seus projetos, discutem a construção de outras representações sobre os espaços das favelas que desconstruam o estigma replicado sobre ser o lugar da ausência, de carências e de precariedades. Neste sentido, propõem construir outra perspectiva sobre tais locais através de características eminentes a eles como, por exemplo, seu caráter de criação e inventividade de formas solidárias de convivência, ou através da valorização da cultura local expressa através da culinária ou da música. (BARBOSA, 2012b). 


\subsection{1 \\ O processo da pesquisa}

Para a entrevista com os fotógrafos, foram pré-selecionadas imagens feitas na Favela Nova Holanda e que estivessem disponibilizadas na internet para a visualização do público em geral. Todas as fotografias foram escolhidas a partir de ferramentas digitais tais como a rede social Facebook, o site de hospedagem de fotos Flickr e o banco de imagens do Imagens do Povo. Tal decisão foi tomada por entender que as fotografias selecionadas por seus autores para serem difundidas em tais meios revelam a escolha dos profissionais para representar o seu espaço a um vasto público em potencial.

A pré-seleção das imagens seguiu determinados critérios, sendo eles: deveriam retratar a Favela Nova Holanda; registrar espaços públicos; registrar o cotidiano local; abordar questões tais como relações sociais, intervenções físicas e/ou uso do espaço.

Como ponto principal, busquei compreender o que o fotógrafo pretendia representar sobre seu espaço a partir da imagem em questão. Antes de prosseguir, cabe aqui pontuar certos elementos sobre fotografia, cruciais à pesquisa. Trabalho sobre o entendido de que a imagem fotográfica não é um "espelho do real”, uma mimese da realidade (DUBOIS, 2015). Ela se refere à interpretação do fotógrafo sobre um determinado assunto. Através da escolha de componentes de ordem material (tal como recursos técnicos, óticos, químicos ou eletrônicos), ou de ordem imaterial (como decisões mentais ou culturais), o indivíduo cria sua representação sobre um contexto determinado (KOSSOY, 2016). Neste sentido, Philippe Dubois (2015) apontará a fotografia como "traço de um real", uma vez que a imagem indiciária ${ }^{103}$ (da qual a foto procede) será dotada "de um valor singular ou particular, pois determinado unicamente por seu referente e só por este (...)" (DUBOIS, 2015, p.45).

Compartilho da visão de Milton Guran (2000) de que uma das potencialidades da fotografia seria justamente relativa a esta questão, uma vez que, ao construir sua 
realidade, o fotógrafo destaca "um aspecto particular da realidade que se encontra diluído num vasto campo de visão, explicitando assim a singularidade e a transcendência de uma cena" (GURAN, 2000, p.157). Neste contexto, a fotografia teria o potencial de registrar elementos que vão além da materialidade em si: ela revela o olhar do fotógrafo sobre o tema, ou seja, revela o que não é visível (MARTINS, 2016). Importante destacar aqui que, apesar de entender que este aspecto denota certa parcialidade sobre a representação produzida, ele se mostra também como possibilidade de acesso a múltiplos pontos de vista (CARMINATTI, 2009), o qual seria um contraponto importante no contexto de imposição de uma visão hegemônica.

Tal questão aponta para a ambiguidade fundamental da fotografia (KOSSOY, 2016), a qual considero também no desenvolvimento da pesquisa:

A imagem fotográfica é antes de tudo uma representação a partir do real segundo o olhar e a ideologia de seu autor. Entretanto, em função da materialidade do registro, no qual se tem gravado o vestígio/aparência de algo que se passou na realidade concreta, em dado espaço e tempo, nós a tomamos, também como um documento do real, uma fonte histórica. (KOSSOY, 2016, p.32)

Em outras palavras, a imagem fotográfica carregará sempre os binômios registro/criação, testemunho/criação, elementos que devem guiar as análises de fontes fotográficas. Neste sentido, o documento fotográfico não poderá ser entendido independentemente do processo e contexto em que se originou. É preciso considera-lo como "representação a partir do real, registrado como um aspecto selecionado daquele real, organizado cultural, técnica e esteticamente" (KOSSOY, 2016, p.57). Considero tais questões para tratar das imagens expostas aqui. Para finalizar as colocações fundamentais para esta pesquisa sobre o campo, compartilho da visão de Martins (2016) que,

A fotografia é um dos componentes do funcionamento desta sociedade intensamente visual e intensamente dependente da imagem. Mas, obviamente, não é o melhor retrato da sociedade. É nessa perspectiva que se pode encontrar o elo entre cotidianidade e a fotografia, a fotografia como representação social e memória do fragmentário, que é o modo próprio de ser da sociedade contemporânea. Mesmo que tenha tido uma origem difusa e funções inespecíficas, a fotografia vai se definindo, no contemporâneo, como suporte da necessidade de vínculos entre os momentos desencontrados do todo impossível, como documento da tensão entre ocultação e revelação tão características da cotidianidade. (MARTINS, 2016, p.36) 
Frente à disputa por representações distintas sobre o Rio de Janeiro, as imagens dos fotógrafos da Maré seriam uma forma de desconstruir/questionar as representações endereçadas a tais espaços, assim como - e/ou através de - de destacar aspectos e potencialidades locais, mostrando, desta forma, as características da Nova Holanda a partir de elementos que os fotógrafos consideram qualidades representativas em seu espaço. Neste contexto, afinal, o que estaria sendo desconstruído e o que estaria sendo destacado? A partir de tal questão, desenvolvi uma série de entrevistas semiestruturadas em profundidade orientadas diretamente pelos pontos destacados acima.

Assim, através de tais entrevistas e a partir do material fotográfico, o conteúdo a seguir foi estruturado. Ao longo da pesquisa, importante salientar, baseei-me nas proposições metodológicas de Kossoy (2016) de análise e interpretação de fontes fotográficas, sendo elas: i) considerar os elementos que compõem sua materialização documental (assunto, fotógrafo, tecnologia, lugar e época); ii) identificar detalhes icônicos ${ }^{104}$ que compõem o conteúdo; iii) buscar a história própria do assunto (seja no momento em que foi registrado, seja da representação); iv) buscar o "desmonte da condição de produção", ou seja, o processo que resultou na representação. (KOSSOY, 2016, p.56-57)

\subsection{2}

\section{Sobre os fotógrafos}

A pesquisa foi desenvolvida a partir do olhar de três fotógrafos: Bira Carvalho, Elisângela Leite e Rosilene Miliotti. Cada um deles foi entrevistado separadamente e a partir de suas próprias fotos. Antes de apresentar a análise, cabe aqui apresenta$\operatorname{los}^{105}$.

Bira Carvalho ${ }^{106}$, apesar de ter vivido em outros bairros na infância, sempre frequentou a Nova Holanda, onde foi morar, definitivamente, na adolescência. Formado pela primeira turma do Imagens do Povo, o fotógrafo é, desde o primeiro

104 Kossoy define como ícone a "comprovação documental da aparência do assunto e da semelhança que o mesmo tem com a imagem; isto em função da característica peculiar do registro fotográfico cuja tecnologia possibilita a obtenção de um produto iconográfico com elevado grau de semelhança com o referente que lhe deu origem" (KOSSOY, 2016, p.35).

$105 \mathrm{O}$ ordenamento das descrições segue a ordem de entrevista concedida.

106 Ver: https://www.facebook.com/bira.carvalho.73/photos_albums 
semestre de 2017, um dos coordenadores do banco de imagens que o programa criou. Segundo o Bira, seu trabalho é feito para as pessoas da Nova Holanda, as quais são para ele a "alma" do local (termo utilizado pelo fotógrafo). Por este motivo, até o momento da entrevista em novembro de 2016, suas fotos eram expostas apenas na rede social Facebook, ferramenta através da qual ele acredita ser a melhor opção de acesso para que os moradores possam vê-las e compartilhálas, apropriando-se, assim, das imagens que representam suas lembranças e seus cotidianos. Como aponta Bira Carvalho:

Eu não boto foto no banco de imagens. Eu fico sempre me questionando: será que eu tô virando "cafetão de favela" também? Mas eu me vejo voltando a fotografar quando vem a ameaça da UPP. E eu me vejo como cúmplice dos moradores porque eles vêm me procurar: "ali o Bira". E eu na rua fotografando. Eu gosto de colocar nas redes sociais para o morador ter acesso a essas imagens. Porque a favela tem exposição [de fotografia] em todo o mundo, menos na rua [da favela]. E isso sempre me incomodou. E aí, quando que o morador vai ter acesso a essas fotos? Porque ele não vai entrar no banco de imagens [do Imagens do Povo] para olhar. E eu coloco nas redes sociais para ele ter acesso e poder pegar essa imagem que é dele também. Eu não coloco [no banco de imagens] por uma questão política. Eu faço parte desse projeto [Imagens do Povo] por causa dessa construção sobre uma nova percepção sobre favela. Mas o que eu gosto mesmo, eu boto no Face [Facebook]. E o morador já vai lá, compartilha a foto, gosta, escreve um pedaço da música dos Racionais [Racionais MC]... É dele essa percepção [sobre a favela] também. Se você for no meu Face você vai ver minhas fotos muito mais do que em qualquer outro lugar.

O entendimento sobre o espaço (tal como veremos a seguir) e sua representação se mostram, para Bira, como um constructo coletivo. Ao mesmo tempo - e consequentemente -, como algo que pertence a todos que o vivenciam e que, continuamente, vai sendo construído e transformado. Partindo de tal olhar sobre sua fotografia, nada seria mais pertinente do que buscar uma forma em que tais representações materializadas em suas imagens continuassem a ser reproduzidas, reafirmadas e, quem sabe, reinventadas por quem também as construiu, ou seja, o próprio referente ${ }^{107}$. E o espaço da rede social funcionaria para Bira como uma ferramenta para tanto.

107 O sujeito fotografado, chamado também de "referente", como aponta Roland Barthes, seria "a ordem fundadora da fotografia", o que é intencionalizado em uma foto (BARTHES, 2015, p.67). Complementando o pensamento, o autor aponta que "eu poderia dizer isso de outro modo: o que funda a natureza da fotografia é a pose", a qual seria uma “intenção' de leitura" (BARTHES, 2015, p.68) 
Elisângela Leite ${ }^{108}$, a segunda fotógrafa a ser entrevistada, nasceu no estado da Paraíba e cresceu em Pernambuco. Ao vir para o Rio de Janeiro aos quinze anos com o intuito de trabalhar, foi morar em Copacabana. Quando decidiu morar definitivamente na cidade, escolheu mudar-se para a Nova Holanda, onde uma tia já vivia. Segundo Elisângela, sua escolha foi pela "liberdade, dessa troca de você sentar na calçada e ficar batendo papo com o vizinho até tarde da noite". Formada em pedagogia e em fotografia pelo Imagens do Povo, hoje atua como fotógrafa e no jornal Maré de Notícias. Ao falar sobre o interesse em fotografar a Maré, Elisângela aponta:

\begin{abstract}
A maioria das minhas fotos, eu não tiro por dinheiro. Eu tiro porque eu gosto. E pelo conhecimento, porque vai passando e mostrando a realidade da favela que nem sempre é o que a mídia mostra, ne? A mídia só mostra violência. Não tem esse outro lado que mostra o dia a dia, o cotidiano, que as pessoas trabalham, estudam, se divertem, fazem faculdade e tudo mais. Nosso trabalho é de formiguinha, de mostrar: ó, não é bem assim não...
\end{abstract}

O que motivou Elisângela a entrar para o Imagens do Povo, segundo seu relato, teria sido seu namorado e o círculo de amigos, todos fotógrafos, também formados pelo projeto. A fotografia, uma ferramenta a qual ela nunca havia prestado especial atenção, teria a partir daí passado a influenciar diretamente em sua forma de enxergar o mundo e os acontecimentos ao seu redor. Segundo Rosilene:

Aí comecei a fazer [fotografia] e me apaixonei, ne? Tu começa a ver o que você não via dentro da sua favela, da sua realidade, do seu dia-a-dia. Dessa beleza que você passa batido e não vê. E as pessoas falam "pô, vai fotografar isso aqui por que? Isso é feio". Aí você começa a dialogar... "não, isso não é feio". Aí tu começa a explicar, a mostrar o outro lado... aí a pessoa diz "é, realmente, tem razão... só mostra isso, só mostra aquilo...". Começa a ter outro pensamento, mais crítico, né? E foi assim que eu fui me envolvendo na fotografia. (...) E isso é muito gostoso de você mostrar o que as pessoas não conhecem e de você também mudar o seu ponto de visão. Parece que você estava cego e de repente abre a sua visão e você começa a enxergar varias coisas que antes você nunca tinha visto na sua vida.

Assim como a transformação em seu olhar, Elisângela destaca também a potência que a fotografia teria para gerar questionamentos e diálogos com terceiros, sejam pessoas que também morem na Nova Holanda, sejam pessoas que não conhecem a

108 ver: https://www.facebook.com/elisangela.leite.927/photos_albums https://www.flickr.com/photos/elisangela_leite/albums/ 
favela pessoalmente. A representação construída é vista como uma maneira de se transformar a vivência e percepção sobre o espaço.

A terceira fotógrafa a ser entrevista, Rosilene Miliotti ${ }^{109}$, é moradora do Parque União desde que nasceu - favela vizinha à Nova Holanda. Formada em comunicação pela ESPOCC ${ }^{110}$ e em fotografia pelo Imagens do Povo, conta que uma de suas motivações para fotografar é poder garantir que a identidade e a memória da Maré sejam registradas para as gerações futuras. Ao apontar tal questão, Rosilene aborda preocupações comuns a Bira Carvalho, no que concerne ao fotografar para os moradores da Maré. Segundo a fotógrafa:

(...) E essa é a importância do jornalismo comunitário e da fotografia, na base, de você tá fazendo registro daquilo, naquele lugar. O Seu João Bolinha ${ }^{111}$ foi capa de um livro sobre a Nova Holanda. Então ele já está ali, já foi capa, já foi matéria. Tem outros fotógrafos que tem foto dele... Então, se amanhã ou depois ele não estiver mais aqui, sei lá, se eu tiver um filho, ainda estiver morando na Maré, vou poder falar "olha, esse é o Seu João Bolinha, que fim de tarde ia pra rua vender bolinha de sabão". Então tem esse registro. Infelizmente muitos morreram, e não tem esse registro. É essa a importância desse trabalho embaixo... de registrar isso, de marcar a presença dessas pessoas, desses personagens. Muitos deles têm, certamente o Seu João tem, a sua história ligada com a história da Maré.

Também em comum aos outros fotógrafos, Rosilene aponta para a fotografia ter transformado sua forma de enxergar o cotidiano:

Com a fotografia eu comecei a perceber um mundo que antes eu não percebia. Ela foi muito boa para mim nisso. Mesmo morando ali, muita coisa você passa direto. Já está na rotina dele. E a fotografia, ela desperta para isso: para você perceber coisas que rotineiramente a gente não ia perceber.

Segundo seu relato, ter a câmera na mão seria ainda uma oportunidade de reviver memórias da infância tal como pegar doces nas ruas da Maré no dia de São Cosme e São Damião. Atualmente, Rosilene Miliotti atua como fotógrafa e jornalista da ONG Fase.

\footnotetext{
109 ver: https:/www.facebook.com/rosilene.miliotti/photos_albums https://www.flickr.com/photos/rosilenemiliotti/albums/with/72157633906096173 http://imagensdopovo.photoshelter.com/search?I_DSC=rosilene+miliotti\&I_DSC_AND=t\&_ACT $=$ search

110 Escola Popular de Comunicação Crítica (Espocc), criada pelo Observatório de Favelas em 2005.

111 Morador que aparece em uma de suas fotografias, abordada mais à frente.
} 


\section{3 \\ As representações construída sobre o cotidiano local}

Apesar de cada um dos três fotógrafos apresentar uma leitura própria sobre o espaço e trabalharem temas distintos, é possível perceber também muitas semelhanças entre suas representações. Entre imagens que falam sobre encontros, apropriação, confraternização, luta e fé, os fotógrafos revelam um local dinâmico e plural. Mostram um espaço de resistência que reivindica, através das ações mais cotidianas, o seu direito de acessar a cidade e participar de sua construção. Apontam para a importância do aspecto lúdico no cotidiano, falam sobre elementos como a espontaneidade, o espaço comum como lugar de encontro, de movimento e da mistura.

Procuro nas páginas seguintes pontuar os assuntos que se destacaram durante as entrevistas através de quatro sub-itens, os quais apontam para aspectos como: a forma de apropriação do espaço comum; o compartilhar do espaço entre pessoas e fazeres plurais; o processo de constante transformação - que ocorre em distintas esferas -, consequência das trocas e encontros naturais ao espaço; a presença da fé e da postura de resistência dos moradores, as quais se materializariam através do espaço.

\subsection{1 \\ Espaço próprio}

Uma das características apontadas sobre a Nova Holanda, recorrente durante as entrevistas, foi referente à força da apropriação da rua feita pelos moradores. Os espaços comuns seriam entendidos como "próprios", lugar no qual intervenções temporárias e usos cotidianos materializariam desejos particulares para os locais onde se vive.

Neste contexto, "sentir-se em casa", segundo os fotógrafos, seria um sentimento recorrente entre os moradores em relação ao espaço comum. A rua, ao invés de pertencer à categoria de espaço "formal, de circulação" - como comumente conhecida (MELLO et al., 1985) -, seria usada como o espaço do "estar". Tal questão nos remete a MELLO et al. (1985), no projeto sobre o Catumbi, pesquisa 
na qual questionam postulados da teoria urbanística através da análise da escala da casa, da rua, do quarteirão e do bairro. Segundo os autores, compreender as formas de apropriação do espaço coletivo seria uma maneira para melhor entendimento sobre o desenvolvimento da cidade (MELLO et al., 1985, p.11).

A forma como os autores analisam o espaço do Catumbi - a partir de uma proposta de reclassificação do espaço coletivo - inspira a pesquisa aqui apresentada a pensar também sobre o espaço da Nova Holanda. Tal como já apontava Lefebvre (2006a), Mello e Vogel falam sobre como o espaço ganha sentido a partir de determinados valores e categorias criados por quem o utiliza. "Um sistema de espaços existe em conexão com um sistema de valores. Por sua vez, ambos são impensáveis sem a existência de um sistema de atividades." (MELLO et al., 2005, p.296)

A partir de tal entendimento, defendem que as conexões comuns entre os conjuntos "espaço" (tais como casa, rua e suas categorias homólogas tais como quintal, calçada, etc), "valores" (como público e privado, entre outros) e "atividades"/"usos" (trabalho, lazer, moradia) não devem ser compreendidas de forma rígida, como geralmente seria feito pela elite acadêmica e técnica - questão que interferiria em projetos urbanos e definições sobre a qualidade urbanística dos lugares.

Tomemos como exemplo as categorias "rua" e "casa". Os autores defenderão que cada uma destas categorias poderia "extrapolar" sua própria definição. A “casa", por exemplo, que é entendida como o ambiente da intimidade, da informalidade e do privado, poderia também ser vista como um espaço de trabalho, caso a mesma possua um cômodo funcionando como tinturaria (caso citado sobre o Catumbi) ou uma barbearia (exemplo abordado por um dos entrevistados sobre a Nova Holanda), por exemplo. A possibilidade de "dupla função" da casa faria com que ela deixasse de ter apenas a imagem "associada com a família, com os laços da substância (DA MATTA, 1978 apud MELLO et al., 1985) entre parentes e amigos", para assumir também a representação de um local ligado ao universo da formalidade das relações e da visibilidade.

À rua, por sua vez, segundo o entendimento "comum", pertenceriam os estabelecimentos ou negócios, além da função de "rua em si" - como via de 
deslocamento. A ela, caberiam conjuntos sociais que se polarizam em relação à casa:

É o mundo das relações contratuais que regem o convívio e a interação daqueles que não têm outros laços de união além da sua igualdade enquanto cidadãos. Domínio público, por excelência, a rua é o lugar onde se dão as relações formais, expostas e visíveis, medidas pela lei e pelo dinheiro. A casa é, no limite, o domínio da pessoalização e das obrigações mútuas que regem esse mundo de pessoas. A rua é, também no limite, a esfera da impessoalidade (DA MATTA, 1979 apud MELLO et al., 1985, P.XX)".

Apesar de toda a rigidez da definição de Da Matta, Mello et al. defenderão que as relações de ambas categorias (casa e rua) serão mutáveis de acordo com cada espaço:

Não falamos de um significante simplesmente constituído como código arquitetônico. Falamos de um espaço constituído por significados sociais representados pelo conjunto das cenas cujos artífices e atores se reúnem." (MELLO et al., 1985, p.65).

O processo de apropriação do espaço se daria segundo a maneira como as diferentes funções primárias da vida urbana se conectam. "Não haveria uma coisa apropriada para cada espaço, nem um espaço apropriado para cada coisa. A mistura não é um acidente. É o estilo da vida urbana nessa área" (MELLO et al., 1985p.128).

As descrições feitas sobre o valor da rua no Catumbi e as misturas entre categorias remetem ao que os fotógrafos entrevistados relatam e representam em suas imagens sobre a Nova Holanda. Lá, a rua também não se caracterizaria segundo as definições de Da Matta (apud MELLO et al., 1985). Pelo contrário, suas formas de apropriação remetem a usos ligados à ideia do privado, da informalidade, da família características "pertencentes", teoricamente, à categoria “casa”. A rua, segundo eles, "é casa". Porém, ao discorrer sobre o assunto, tanto Bira Carvalho quanto Elisângela Leite são ainda mais específicos em relação à descrição. É interessante notar que em ambas entrevistas se falou sobre a rua ser "o quintal". Como aponta Bira:

A rua é o quintal da minha casa. A "rua" só é "rua" porque tem esse nome. Para mim, é o quintal da minha casa. O espaço que é meu. Eu começo a ter estranhamento quando eu chego na [Avenida] Brasil. Mas todo o complexo pra mim, mesmo com as facções diferentes, eu consigo ver como o quintal da minha casa. É o local da minha relação social, é o local da minha psicanálise. É o local dos encontros, o local das lembranças, mas também uma grande escola. 
A rua, ao ser "quintal" - e não apenas "casa" -, toma um outro caráter além do aqui descrito por Mello et al. Ela abrangeria, de certa maneira, a característica de ser um local entendido como próprio da esfera privada, frequentada por familiares e amigos (tal como a casa), tendo porém, um nível de intimidade distinto da provida por um ambiente fechado entre "quatro paredes". A ideia de "quintal" estaria atrelada à confraternização e às trocas entre grupos, agregaria também a noção de espaço com pluralidade de usos, de local no qual diferentes atividades seriam desenvolvidas.

Seja através do encontro, da confraternização ou de seus outros tantos usos, a ideia de "quintal" impõe um entendimento específico sobre o espaço como "próprio", o que se reflete não só sobre cuidados relativos ao lugar, mas também sobre o sentimento de pertencimento que os indivíduos possuem em relação a ele.

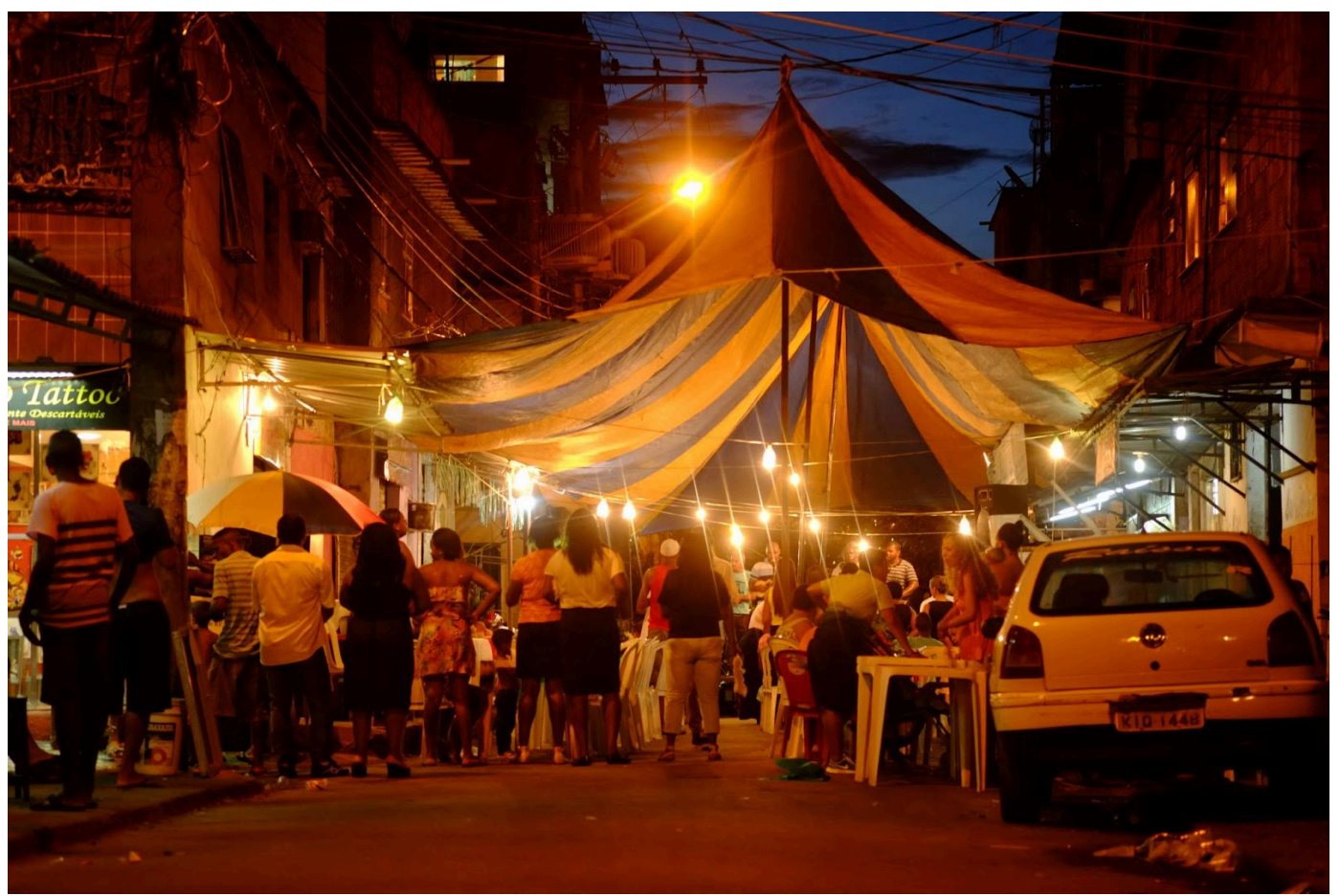

Figura 17 - Fotógrafo: Bira Carvalho

Tais questões podem ser vistas através da Figura 17, de Bira Carvalho. Nela, de um lado a outro, uma grande tenda é estendida. Suas pontas são amarradas nas estruturas das casas que beiram a via. Abaixo da tenda, fileiras de lâmpadas para iluminar o espaço. O local reúne pessoas em mesas e cadeiras, assim como pessoas em pé. Não sabemos através da imagem qual evento acontece ali, porém, o que fazem de fato, não parece ser o assunto de principal interesse do fotógrafo. Bira não 
parece estar preocupado neste registro em revelar o que os indivíduos olham ou sentem, mas sim aparenta querer mostrar a forma como ocupam e se integram ao espaço. A rua - durante aquele momento - é daquelas pessoas e sua estrutura parece estar aberta a quem mais quiser se agregar ao grupo, uma vez que não apresenta qualquer barreira de entrada.

Ao falar sobre o registro, Bira descreve primeiramente o que era o evento: um culto evangélico na rua, da Igreja Vernáculo de Fogo. Logo depois, o fotógrafo comenta sobre outro evento que estava sendo montado no momento da entrevista, no mesmo local:

Se você olhar dali de fora, está sendo montado hoje um pagode. Então é um espaço onde as pessoas utilizam a rua, e eu gosto dessa coisa mais aberta a todos. Seja religioso, seja cultural... o que eu gosto nessa foto é que eu vejo a confraternização na rua.

O que chama a atenção na fala de Bira são três questões principais: o valor que dá à apropriação do espaço pelos moradores, sua admiração pela diversidade dos usos em um mesmo local e pela finalidade destinada às diversas apropriações - a confraternização. A essência do que seria "favela" para ele é ligada à noção da apropriação da rua como espaço simultaneamente coletivo e particular.

A rua é isso [a forma de ocupação da foto]. Isso representa muito para mim o que é favela. O que é a favela? É você chegar e ter a rua como sua. Ela é do coletivo, mas ela é sua. Você se apropria daquele espaço público. Ele é público, mas é seu também. Talvez isso seja o que mais me agrada.

A Figura 18, de Rosilene Miliotti, é também representativa sobre tais questões. 


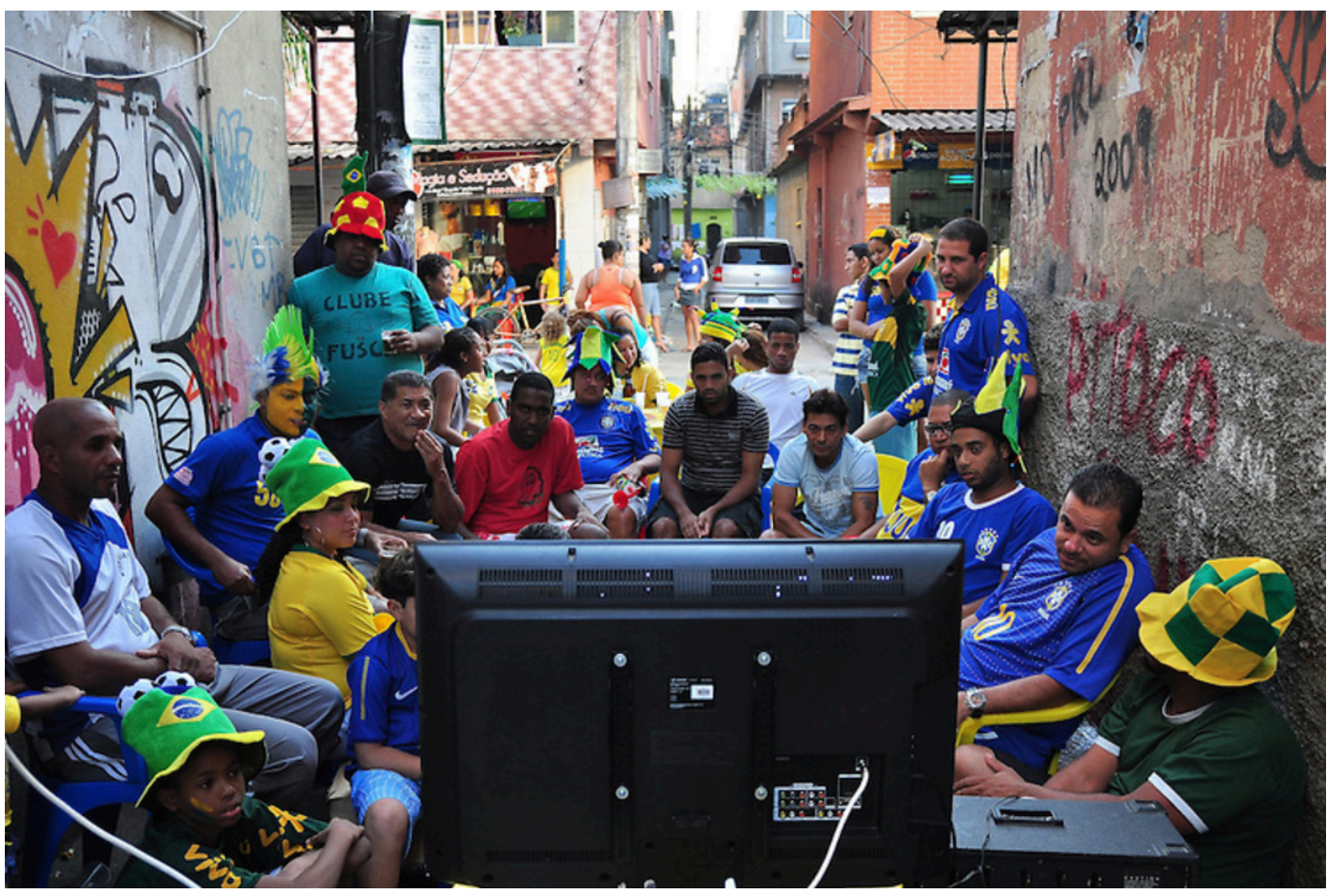

Figura 18 - Fotógrafa: Rosilene Miliotti

A fotografia faz parte do ensaio da fotógrafa sobre a Copa do Mundo de 2010, no qual seu objetivo era mostrar a forma como as pessoas estavam se reunindo para assistir ao evento de futebol naquele ano. O espaço seria uma rua estreita, na qual eventos de naturezas distintas são comuns, como aponta Rosilene:

Aqui é uma rua. As ruas ali perto da [rua] Principal são muito estreitas. Então as pessoas geralmente fecham, fazem festa de aniversário, botam piscina... enfim, elas fecham. E muitas vezes os vizinhos são da família. A família mora ali. Então vai todo mundo para aquele lugar. Aqui [na foto] são todos amigos. Você tem família, mas também os amigos, e não necessariamente gente que mora nesse pedacinho.

No ensaio realizado na ocasião ${ }^{112}$, é comum vermos ruas enfeitadas e pintadas com cores da bandeira nacional, movimento que se vê também em outros bairros do Rio de Janeiro assim como em diferentes cidades do Brasil. Na Figura 18, porém, o registro revela um "apropriar-se" que extrapola o enfeitar do espaço e promove a montagem de um "telão" no centro da via.

Aqui [diz apontando para as laterais das paredes] tem dois bares - ou tinha, porque as coisas mudam com uma velocidade! Então tem dois bares aqui do lado e então as pessoas vieram pra cá, e botaram a televisão, que é dessa casa [a casa da lateral esquerda]. E botaram televisão, caixa de som... as cadeiras são dos bares... e aí pega cerveja ali mesmo, e comida cada um traz alguma coisa.

112 Outras imagens do ensaio estão disponíveis em: http://imagensdopovo.photoshelter.com/search?__DSC=rosilene+miliotti+nova+holanda\&I_DSC_ $\mathrm{AND}=\mathrm{t} \& \_\mathrm{ACT}=$ search 
A televisão, pertencente a uma das casas da rua, motiva o encontro entre os vizinhos e amigos, que transformam a entrada de sua rua em um local de torcida pela seleção de futebol. O entendimento de Bira sobre a rua "ser pública, mas ser também sua" parece se reproduzir na fotografia e no relato de Rosilene. O "quintal" dos moradores do logradouro reúne em uma esfera familiar os amigos e mantem-se aberto a quem mais quiser se juntar ${ }^{113}$. O uso de cadeiras do bar e a televisão de uma casa compõem um espaço onde o comum e o privado parecem mesclar-se com naturalidade. Entre a atmosfera de tensão dos olhares dos torcedores e descontração proposta pelos acessórios temáticos, vemos um local onde os presentes transmitem a ideia de pertencimento.

A fala de Rosilene aborda ainda outras questões sobre a natureza do "apropriar-se" do espaço e do uso das ruas da Nova Holanda para confraternizações. Segundo ela, foi curioso notar que na Copa do Mundo de 2014, realizada no Brasil (tendo o Rio de Janeiro como uma das cidades-sede), não houve a mesma mobilização entre os moradores da Nova Holanda:

E aí é legal que, na Copa aqui no Rio, a gente já percebeu um movimento ao contrário: não tinha ninguém se mobilizando nas ruas, ninguém estava animado nem para fotografar, quanto mais fazer churrasco e essas coisas. A gente não viu televisão na rua. Então a animação era zero. Tinha a questão do exército na rua, mas na Nova Holanda e no Parque União [a ocupação militar] não implicava em nada... a vida continuava normal. Praticamente normal na Nova Holanda com o exército. Acho que tinha muito a ver com o contexto, com essa desconfiança sobre o que ia acontecer com os estádios, essa roubalheira toda. Já tinha esse movimento, sabe? Você não via ninguém empolgado. Ali em frente à Redes tem um bar, não sei mais se é o do Rodriguinho, mas sempre tem um telão pra ver jogo, ele é muito flamenguista, e pra Copa mesmo não tinha nada. Era como se não tivesse acontecendo nada. Tinha o barulho que devia ser de bar, alguma coisa, mas esse movimento, sem ser de bar, na rua, de pegar a televisão e botar na rua, fazer churrasco... Eu andei, cheguei a circular - não pra fotografar, eu queria ver - e a gente não viu nada. Pode ser que tenha acontecido porque a Maré é grande pra caramba... mas por onde eu andei, por onde circulei, não vi nada.

Rosilene aponta ainda como os usos destinados ao espaço estão ligados diretamente aos acontecimentos vividos no momento, destacando o caráter de espontaneidade. Neste contexto, assim como a rua pode não ser usada para a confraternização durante a Copa do Mundo de um determinado ano, um encontro em um dia comum

113 Um exemplo que demonstra a receptividade dos moradores em eventos como estes é o relato de Rosilene sobre como era recebida entre os grupos (de desconhecidos) que fotografava: "Cada lugar que eu ia eu comia um pouco.. se não comesse, eles ficavam chateados." 
entre amigos no bar pode resultar na decisão sobre o uso de uma rua de médio porte para uma grande festa, como aponta a fotógrafa:

Agora eu descobri o "Arraiá do Boi Bravo", que o pessoal, num dia num bar, decidiu fazer uma festa junina. Um pessoal perto da Vila Olímpica, nas casinhas, e aí eles pegam aqueles coqueiros secos, e saem enfeitando tudo, colocam faixa "Arraiá do Boi Bravo", arrumaram uma cabeça de um boi preto pra enfeitar... assim, uma festa! E eles se preocupam muito com a ornamentação daquele espaço ali. Nem todos moram ali. Um ou outro moram naquele lugar, e ai é uma rua bem larga que não passa carro nem nada a e eles se juntam, botam grana, alugam um som, e é um dia só, para se divertirem.

As Figuras 17 e 18 - assim como os relatos apresentados até aqui - mostraram confraternizações realizadas em datas específicas, pré-estabelecidas e préorganizadas. Diversos outros registros e depoimentos, por outro lado, apontam para representações que falam sobre apropriações menos "elaboradas" - mas que também objetivariam a confraternização. A Figura 19, de Elisângela Leite, é um destes exemplos.

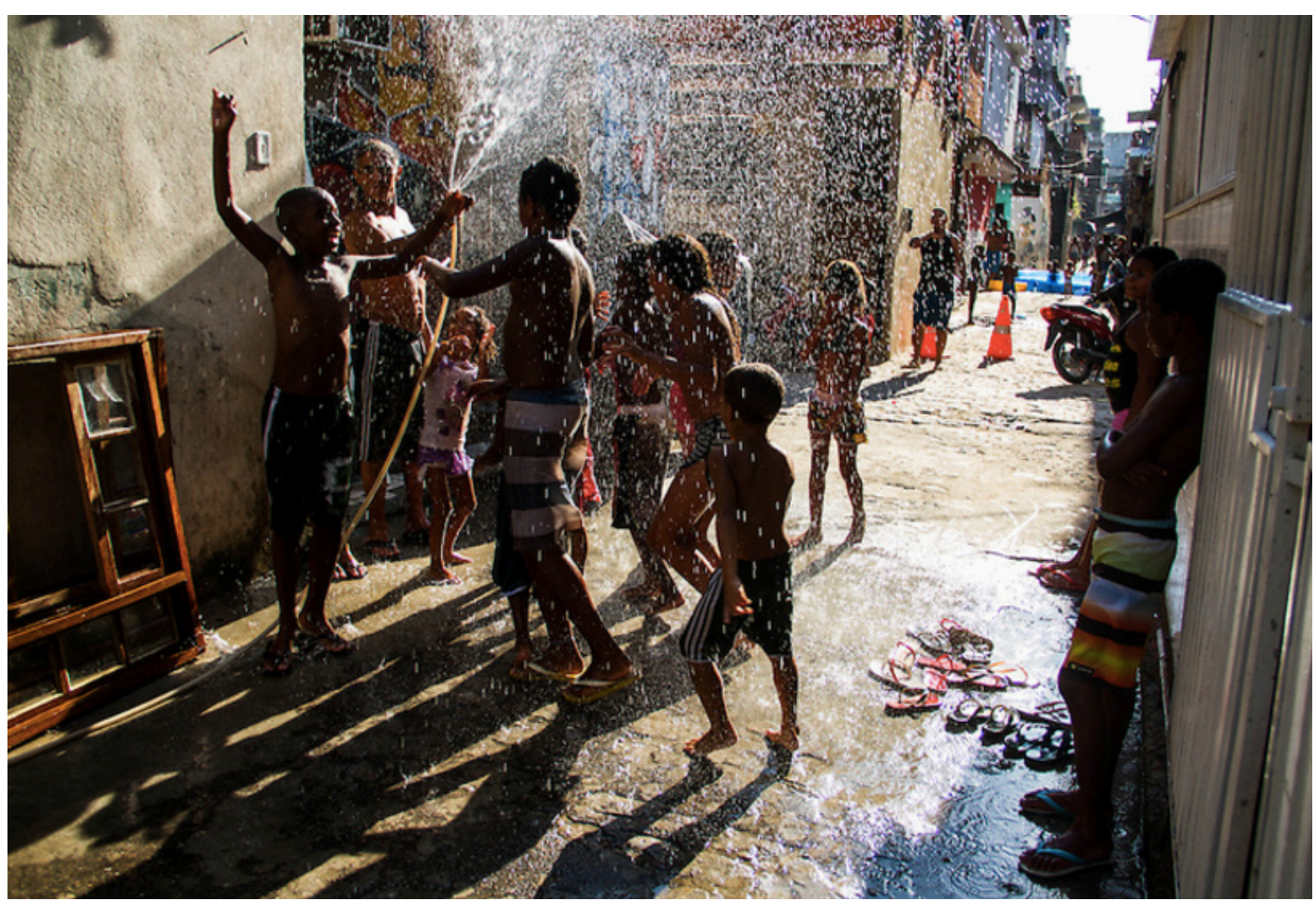

Figura 19 - Fotógrafa: Elisângela Leite

Nela, a fotógrafa registra uma cena onde crianças de diferentes idades se divertem em um dia ensolarado ao tomar banho de mangueira. Apesar de duas das crianças estarem encostadas na casa do lado oposto, apenas observando a brincadeira, podemos contar cerca de nove outras entregues à diversão. $\mathrm{O}$ menino ao lado 
esquerdo, de braços estendidos, é o que melhor vemos a expressão facial: entre a água que cai e a postura expansiva, um grande sorriso. Através de uma mangueira e água jogada para o alto, a estreita rua entre duas casas se transforma em um espaço de diversão genuína. Quem segura a mangueira e possibilita o banho é o senhor no lado esquerdo da imagem (posicionado atrás do menino de braços abertos). Seu nome é Manuel, segundo Elisângela:

O Manuel é o meu vizinho. Ele se amarra em fazer uma bagunça com as crianças: ele liga a bomba e fica com a mangueira lá. Toda a criançada é ali da rua. A Maiara [filha do Manuel] tem 17/18 anos. E ela é muito moleca, dá aula particular de reforço para as crianças em casa. Eles também colocavam barraquinha aqui a noite para vender doce, bolo... e ai a criançada gosta de ficar ali fazendo bagunça. Nesse dia, cada um trouxe uma coisa: um trouxe carne, outro trouxe refrigerante, e fizeram um churrasco. E a mulher dele é que se ferra para fazer [risos]. Ela: "eu que me ferro para fazer, sobra mim"É a forma de lazer do dia a dia. Principalmente no verão, que é férias, os pais trabalham... não tem como acompanhar, sair mesmo.

A partir do uso de uma simples mangueira, mais uma vez a rua se torna o quintal. $\mathrm{O}$ encontro entre pessoas próximas e familiares para a confraternização demonstra que a rua, definitivamente, não se limita ao espaço da impessoalidade, da relação formal e de circulação. Tal questão é reforçada ainda ao olharmos a parte superior direita da imagem. Nela, vemos dois cones que restringem a circulação de veículos ao local e, mais ao fundo, uma piscina de plástico montada ao ar livre.

A diversão e o lazer são levados ao espaço comum através de intervenções distintas, revelando um local transformado através de atividades lúdicas, da imaginação e da Festa $^{114}$. Elementos estes que, como mostramos a partir Lefebvre (2006b) no capítulo 2, seriam essenciais à conformação do espaço: afinal, o ser humano teria a necessidade de habitar em um local que promova tais vivências.

Vemos ainda em outros registros de Elisângela Leite as características supracitadas. Na Figura 20, por exemplo, uma rua de porte parecido com a da Figura 19 é utilizada para uma partida de ping-pong.

114 Sobre o termo "Festa", Lefebvre aponta: "O uso principal da cidade, isto é, das ruas e praças, dos edifícios e dos monumentos, é a Festa (que consome improdutivamente, sem nenhuma outra vantagem além do prazer e do prestígio, enormes riquezas em objetos e em dinheiro)." (LEFEBVRE, 2006b, p.4) 


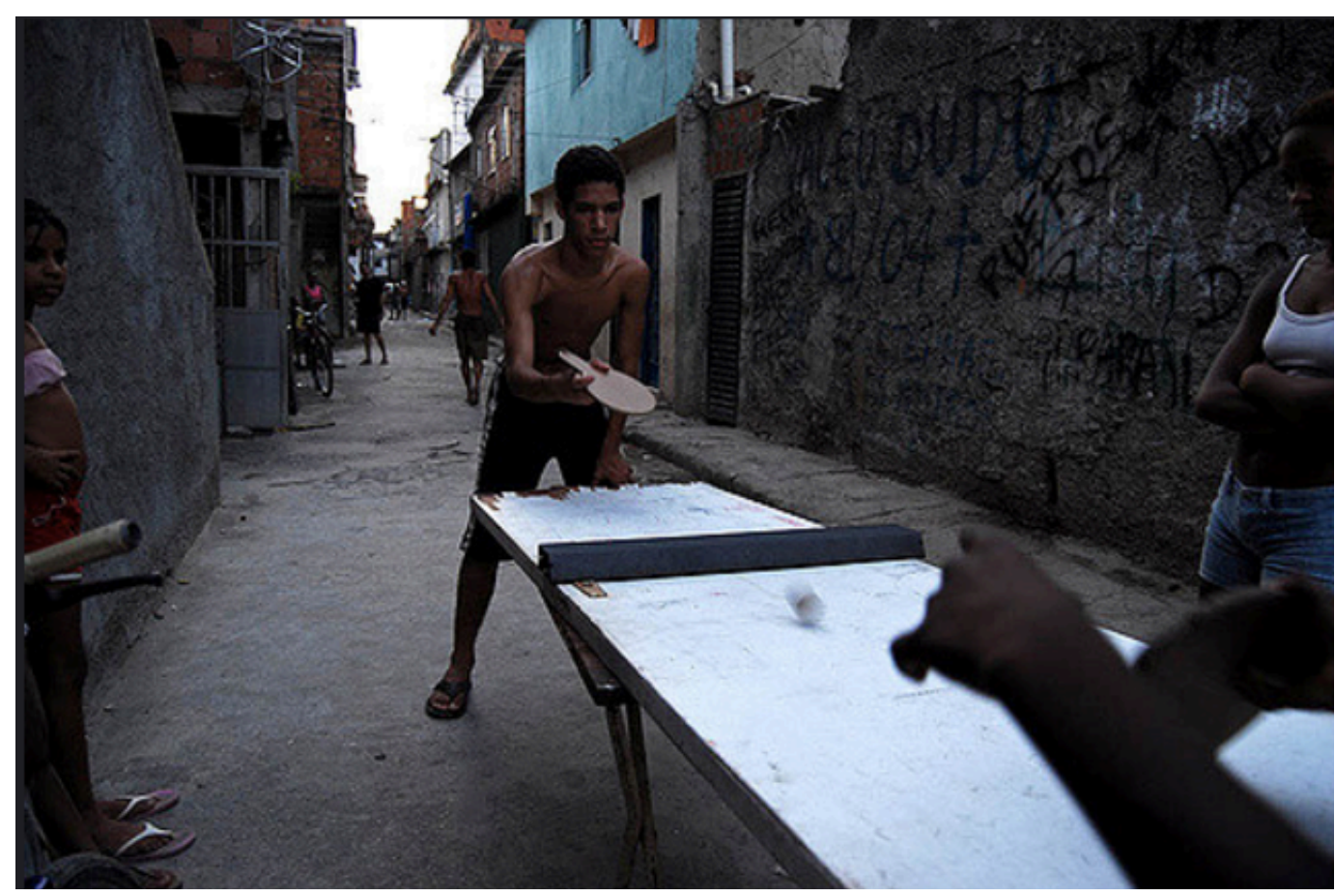

Figura 20 - Fotógrafa: Elisângela Leite

A mesa do jogo é improvisada a partir do que parece ser uma porta apoiada sobre uma mesa de bar; sua divisória é estabelecida através de um perfil de metal. Ao fundo, a imagem mostra as casas da rua e a presença de outras pessoas que também usam o espaço. $\mathrm{O}$ enquadramento destaca um dos jogadores que, atento ao movimento da bola, é assistido por um público de duas (ou três) meninas que acompanham a partida. A presença de espectadores faz supor que o jogo reúna amigos/conhecidos em torno do interesse pelo lazer. O espaço comum, novamente, é apropriado para o encontro com caráter familiar.

Não só Elisângela Leite, mas também Bira Carvalho relatam e registram a multiplicação de mesas de ping-pong improvisadas pelas ruas da Nova Holanda. Segundo a fotógrafa, a transformação da rua em área de jogos deste fim é frequente, mas principalmente durante o período de férias escolares. Neste contexto, a rua passa a ter diferentes conformações ao longo das épocas do ano e através das diferentes apropriações e intervenções próprias a cada período e aos acontecimentos próprios àquele tempo-espaço específico (tal qual as ocupações das Copas do Mundo de 2010 e 2014).

Ainda sobre o caráter de confraternização destinado à rua, outras imagens são representativas sobre ter-se o espaço comum como "quintal". Consideremos aqui 
duas delas, as Figura 21 e a Figura 22: ambas falam sobre apropriações realizadas por crianças; o espaço nas representações construídas parece ser proposto a partir do lúdico e do brincar. A rua é nelas experienciada por vivências do "circular" e do “interagir”: a apropriação do espaço é construída pela surpresa e pelo espontâneo.

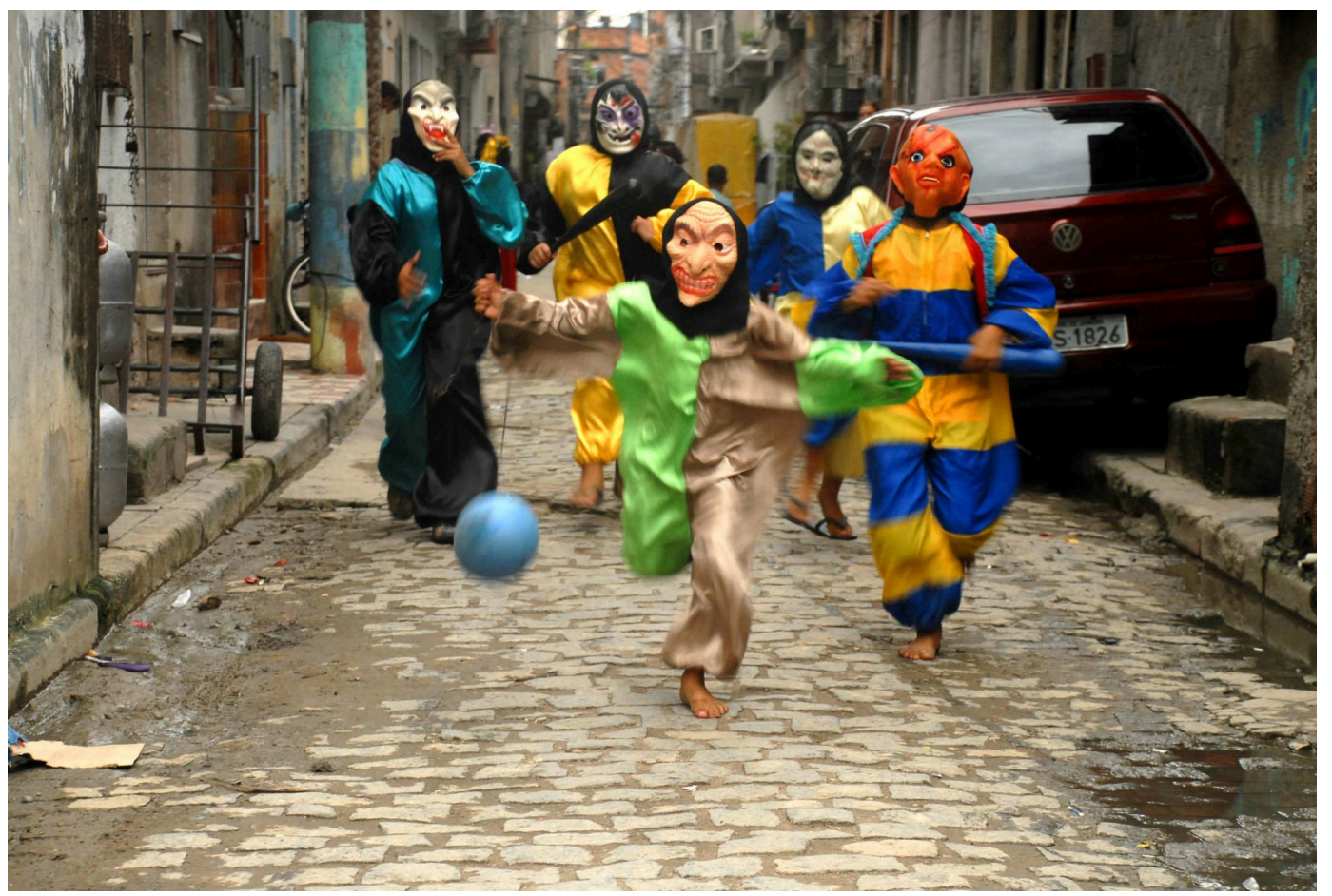

Figura 21 - Fotógrafo: Bira Carvalho

No caso da Figura 21, de Bira Carvalho, cinco crianças fantasiadas de bate-bola correm por uma rua estreita de paralelepípedos. Eles não estão apenas fantasiados, mas sim, parecem "encarnar" os personagens. A fantasia de bate-bola, muito comum nos subúrbios cariocas, remete à ideia de continuidade de costumes, em uma tradição de mais de oitenta anos e que envolveria entre quatrocentas e setecentas turmas, as quais variariam entre cinco e mais de cem membros ${ }^{115}$. Entre o encantamento e o medo, é comuns meninos sonharem com o dia em que poderão sair no carnaval ao meio de turmas de bate-bola - e as crianças da imagem parecem fazer parte deste grupo. Ao relatar sobre o registro, Bira conta sobre como encontrou seus "personagens":

Essa cena eu saio no carnaval, ai eu fiquei pensando: "fotografo, não fotografo...". Ai eu sai, e eles tavam passando lá no miolo [entre as ruas mais afastadas das vias principais]. E eles cantando: "bate bola bate o pé, tira a roupa da mulher, se for homem vem aqui, se for bicha fica ai". E aparecem e somem. Primeiro eu sigo eles,

115 Fonte: Jornal El País Brasil, 01/03/2017. Disponível online:

http://brasil.elpais.com/brasil/2017/02/27/politica/1488224740_612664.html 
mas eles somem. E depois, de repente, eles entram correndo por onde eu tava e, ai "pá", eu faço a foto.

Vestindo máscaras e roupas volumosas e coloridas, os bate-bolas são conhecidos não só pelas fantasias produzidas durante todo o ano, mas principalmente por brincarem de assustar quem passa entre eles. Como definem pesquisadores sobre o assunto, os bate-bolas seriam "produto de grupos de rapazes que se organizam para disputar o espaço das ruas"116, ou ainda grupos que "representam uma certa desobediência e liberdade"117. Entre a disputa pelo espaço e a quebra de acordos/paradigmas sociais, os grupos percorrem as ruas interagindo com as pessoas que os assistem de forma não premeditada. A surpresa faz parte do acontecimento.

As crianças da imagem de Bira parecem querer reproduzir tais atributos dos batebolas. Nisso, o percorrer das ruas transforma-se em uma brincadeira, em uma espécie de jogo, no qual o espaço é experienciado através do inusitado. Os caminhos são escolhidos naquele momento. Os encontros que terão pela espécie de "deriva", são surpresas, assim como as reações que acarretarão.

O menino da frente - o único com bola - parece liderar o grupo, ao menos naquele momento. A liberdade é expressa pelos pés descalços que correm sobre os paralelepípedos. A desobediência parece tornar-se possível através das máscaras que escondem os rostos e das roupas que anunciam que ali vêm os bate-bolas. A música cantada pelos cinco integrantes, a qual ouvia-se a uma relativa distância, segundo Bira, poderia ainda contribuir para compor o caráter "subversivo", pretendido pelo grupo - não só pelo barulho/algazarra gerado, mas pelo conteúdo da letra que, apesar de ser tradicionalmente conhecida, carrega apelo machista e homofóbico.

É interessante notar como relatos sobre vivências nas quais crianças percorrem o espaço, mostrando espontaneidade e apropriação livre entre as ruas, se repetem. Tanto na entrevista de Bira quanto de Rosilene, os fotógrafos colocam a questão da mudança na relação entre crianças e a rua, menos comum hoje em dia, uma vez que

116 Luiz Felipe Ferreira, professor do Instituto de Artes da Uerj e coordenador do Centro de Referência do Carnaval, para BBC Brasil, 9/2/2013. Disponível online: http://www.bbc.com/portuguese/noticias/2013/02/130201_bate_bola_cq.shtml 117 Relato de Felipe Bragança, cineasta, para BBC Brasil, 9/2/2013. Disponível online: http://www.bbc.com/portuguese/noticias/2013/02/130201_bate_bola_cq.shtml 
os pais se mostram mais apreensivos sobre possíveis conflitos entre polícia e tráfico que, não raramente, ocorrem repentinamente e em horários de grande movimento. Por outro lado, porém, assim como o registro de Bira sobre os bate-bolas correndo entre vias do "miolo" da Nova Holanda, Rosilene relata uma vivência que também fala sobre o uso do espaço para o brincar, onde experiencia-se a surpresa através das ruas. Seu relato se desenvolve também a partir de um evento tradicional: a festa de São Cosme e São Damião.

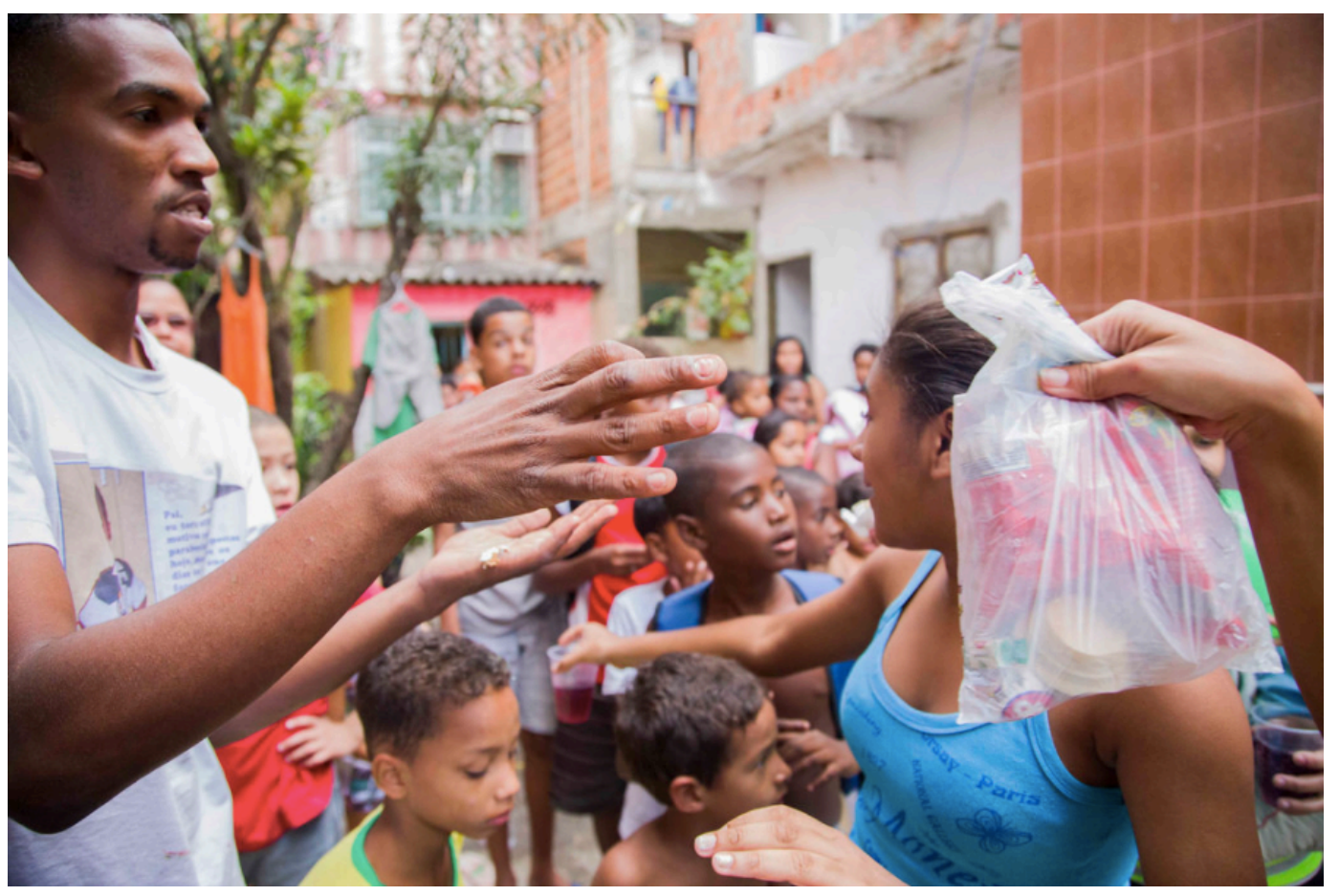

Figura 22 - Fotógrafa: Rosilene Miliotti

A partir da Figura 22, Rosilene fala sobre seu interesse em registrar o dia da comemoração dos santos católicos na Nova Holanda. Na data, festejada no mês de outubro, adultos distribuem doces para crianças, como uma forma de, segundo Rosilene, "agradecer à vida". O costume estaria cada vez mais extinto na Maré por causa do crescimento de religiões neopentecostais, como relata a fotógrafa.

A imagem em questão retrata a distribuição de doces organizada pela família de seu Reinaldo. A motivação inicial para fazê-la, teria sido uma promessa pela saúde da filha. Com doces, bolo, refrigerantes e pequenas lembranças, o senhor reúne a família através da causa. Vestidos com camisetas estampadas com os rostos dos santos, distribuem senhas entre as crianças da região para que peguem os brindes na porta de sua casa. 
Apesar da organização que o morador da Nova Holanda propõe para o dia, a data supõe uma experiência de brincadeira das crianças nas ruas que, motivadas pela ideia de ganharem doces, vão em busca de adultos que estejam engajados na oferenda em homenagem aos santos. Rosilene conta sobre a ocasião em que saiu às ruas no feriado de outro ano para fazer o registro da festividade, juntando-se a um grupo de crianças.

\begin{abstract}
Se não me engano, dois anos depois [após o registro da Figura 6], o dia de São Cosme e Damião tinha caído num domingo. E eu fui pra rua fotografar... peguei um grupo de crianças e fui. E assim, eu andei do Parque União ao Morro do Timbau. A gente não encontrou tantos, mas todos que a gente encontrou foi muito legal, sabe? $\mathrm{E}$ acabei que quase não fotografei... porque eu achei tão legal aquilo com as crianças. Nossa, eu andei tanto com as crianças, tomei uma canseira, viu [ risos]. E elas trocam de roupa, colocam boné pra entrar na fila de novo e pegar mais doce... elas vão, pegam doce, aí esperam encher de gente de novo, aí elas trocam a roupa, vem no portão de novo, e aí dizem que foi a prima que pegou.. Quando alguém percebe: 'não, deve ter sido minha prima, ela que me falou'. E falavam na cara de pau.. é muito divertido.
\end{abstract}

O dia representa a questão da surpresa e da Festa presente no espaço. Percorrer as ruas da Maré em busca de doces, sem saber exatamente onde irá encontrar, brincar de burlar as regras da fila, interagir e trocar com tantas pessoas propõe uma vivência livre no espaço; remete a um lugar onde as ações das pessoas fazem do espaço um local de interação, de troca, de divertimento, de brincadeira.

Se na "cidade-mercadoria" a passividade passa a tomar conta do espaço urbano espetacularizado (JACQUES, 2003), as apropriações feitas na Nova Holanda parecem revelar um espaço oposto a este cenário. A característica de se "ter a rua como sua" representaria, inclusive, uma resposta e resistência a tal imposição de cidade, que não só cria espaços para serem "cenografias”, mas exclui aqueles que não "se encaixam" ao ideal de cidade estabelecido.

Sejam atos conscientes ou não, as intervenções vistas nas fotografias e descritas pelos três entrevistados nos remetem a propostas de pensamentos sobre o espaço urbano desenvolvidas pelo grupo Internacional Situacionista, na década de 1960. De forma sintética, os Situacionistas - grupo formado por artistas, pensadores e ativistas - questionavam a organização que os centros urbanos vinham recebendo. O grupo "lutava contra o espetáculo, a cultura espetacular e a espetacularização em geral, ou seja, contra a não-participação, a alienação e a passividade da sociedade" (JACQUES, 2003, p.13). Ao criticarem o monopólio urbano dos urbanistas e 
planejadores em geral, apontavam para a importância de uma construção realmente coletiva dos centros urbanos. Para os situacionistas, quando os habitantes passassem de simples espectadores a construtores, transformadores e "vivenciadores" de seus próprios espaços, a espetacularização da cidade seria impedida. O meio urbano, na visão da IS, seria visto como "terreno de ação, de produção de novas formas de intervenção e de luta contra a monotonia da vida cotidiana moderna" (JACQUES, 2003, p.26). Em sua visão, a cidade poderia ser formada apenas através dos usos cotidianos e vontades de seus habitantes, e não a partir de "postulados" ou categorias espaciais estabelecidas pela "elite acadêmica e técnica" - como diriam Mello et al. (1985). Como aponta Paola Jacques, "os situacionistas perceberam então que não seria possível propor uma forma de cidade pré-definida pois, segundo suas próprias ideias, esta forma dependia da vontade de cada um e de todos, e esta não poderia ser ditada por um planejador" (JACQUES, 2003, p.19).

E na Nova Holanda, através de tendas para eventos, brincadeiras pelas ruas, banhos de mangueira, televisões ou através de mesas de ping-pong, parece construir uma forma possível para a cidade a partir "da vontade de cada um e de todos"; um espaço apropriado - mesmo que temporariamente - e constituído a partir de vivências e desejos de seus moradores. A rua é palco ativo de "novas formas de intervenção" e de "luta contra a monotonia". O "quintal", próprio de tantos moradores, mostra a riqueza de um espaço constituído pelo valor de uso, onde a experiência urbana não é vivenciada através da passividade e de uma mera "cenografia".

Sobre este assunto, a Figura 23, de Elisângela Leite, é representativa. 


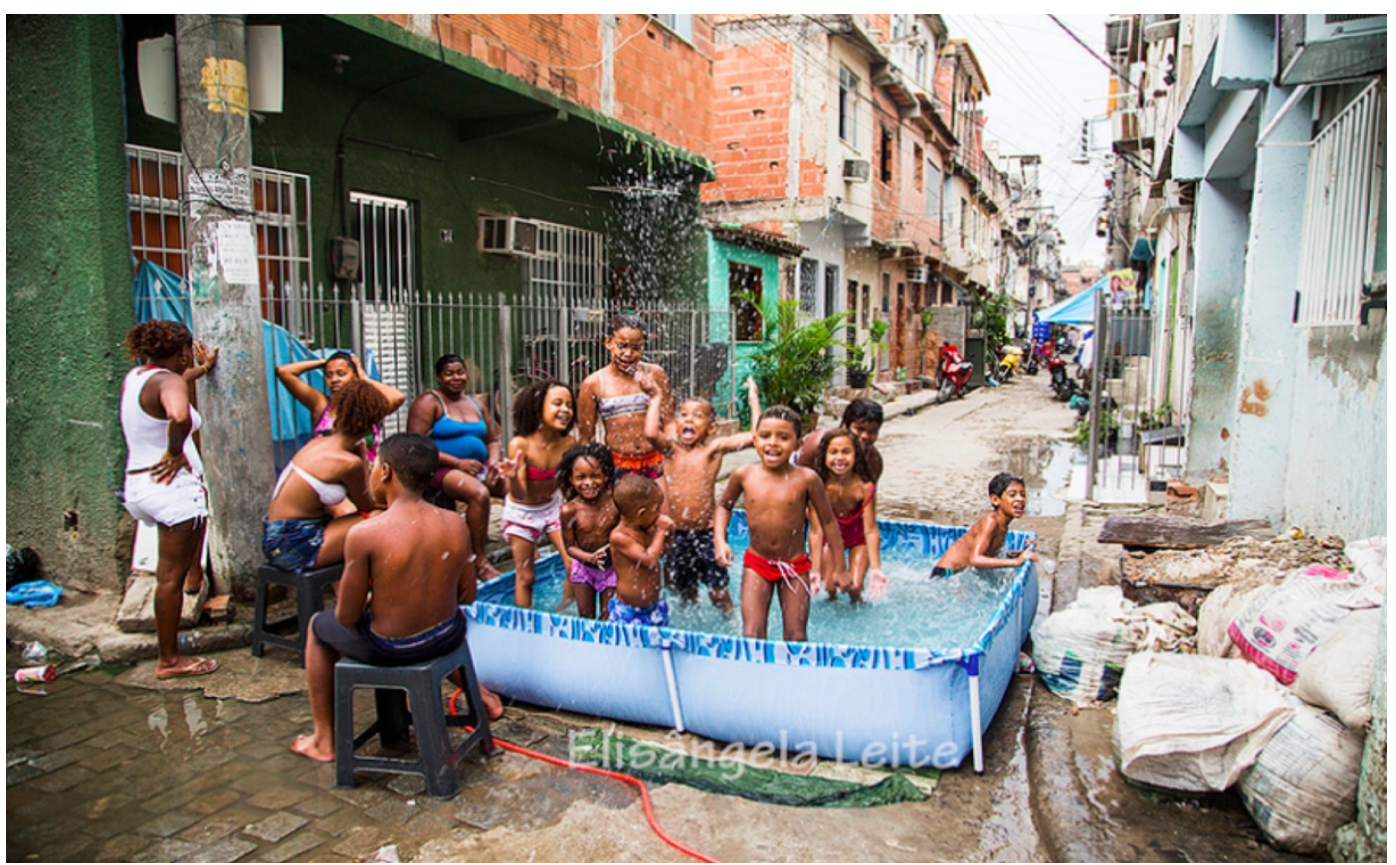

Figura 23 - Fotógrafa: Elisângela Leite

A cena acontece em uma esquina da Nova Holanda. Nove crianças brincam em uma

piscina de plástico montada no centro de uma via. O domínio do espaço é feito pelas crianças que brincam no local e se divertem com a ideia de serem registradas pela câmera. Ao transformarem o espaço entre duas casas em uma área de lazer, os moradores novamente empregam um outro uso para aquele local, demonstrando assim, segundo termos dos Situacionistas, o caráter de legítimos "construtores, transformadores e "vivenciadores"' do espaço; propondo um caminho não só contra a monotonia da vida cotidiana descrita por Jacques, mas também entendendo o espaço como "terreno de ação" para responder ao acesso limitado à cidade, que lhe é imposto ${ }^{118}$. Como aponta Elisângela, ao falar sobre a intervenção da piscina:

Esse é o espaço de lazer... não tem dinheiro para ir para a praia, é mais fácil colocar uma piscina na porta de casa, tomar uma cervejinha e olhar as crianças. Imagina: você tem que levar esse monte de criança, tem que levar alimento, passagem pra pagar e tem a distância, ne? Não tem uma condução direta. Só fazem metro pra zona sul, né? Não tem na [avenida] Brasil para facilitar a vida do trabalhador. Essa mulher mora aqui, essa mora aqui. E as crianças da rua vão chegando e vão se juntando ali também.

\footnotetext{
118 O Censo CEASM levantou dados sobre a circulação dos moradores do Complexo da Maré em outras áreas da cidade, tal como a Zona Sul e a Barra da Tijuca. A média traçada entre as favelas indicou que $30 \%$ dos moradores nunca havia circulado; $32,2 \%$ raramente iam; $17 \%$, apenas no verão; $20,8 \%$ circulam com frequência - índices que demonstram o baixo acesso que os moradores teriam a áreas elitizadas da cidade. Sobre o perfil específico da Nova Holanda, o Censo aponta que $29 \%$ dos moradores nunca havia circulado; $17,9 \%$ raramente iam; $17,9 \%$, apenas no verão; $20,5 \%$ circulam com frequência.
} 
O caráter relativo ao apropriar-se do espaço para torná-lo um local de confraternização e lazer é explicitado de forma contundente pelo menino de bermuda preta que joga água para cima, no centro da imagem. Ele seria em nossa análise o que Roland Barthes (2015) chama de puctum, ou seja, um 'detalhe' que atrai o olhar do observador (BARTHES, 2015, p.40). Sua expressão, "careteira" e espontânea, é a representação da felicidade vivida naquele momento. Seu gesto, expresso quase como uma explosão, parece divertir e envolver os amigos ao lado. E se, ainda em Barthes, “o que funda a natureza da fotografia é a pose” (BARTHES, 2015 , p.68), a postura do menino representa plenamente o que a imagem busca registrar: a apropriação genuína do espaço através do lúdico, do brincar.

Importante pontuar que, ainda a partir dos Situacionistas, a questão do lazer apresenta um limiar entre "alienação" e "revolução", assim como também o apresentaria o conceito de "cotidiano". O cotidiano seria a "fronteira onde nasce a alienação mas onde também pode crescer a participação; assim como o lazer seria o tempo livre para o prazer e não para a alienação, o lazer poderia tornar-se ativo e criativo através da participação popular" (JACQUES, 2003, p.21-22). O lazer revelado pelos fotógrafos demonstra representações de uma atividade que em nada se assemelha à postura passiva.

As relações construídas através do lazer no espaço comum irão moldar o espaço, dar-lhe o caráter plural; irão possibilitar que vínculos sejam construídos e que ocorram trocas entre os moradores. Porém, não só o lazer e a confraternização representarão os usos do espaço, mas as ruas serão ainda o palco de muitas outras atividades, assim como será também compartilhada por pessoas distintas, como visto a seguir.

\subsection{2}

\section{Espaço compartilhado}

Uma outra característica abordada sobre a Nova Holanda - e, podemos dizer, consequência da forma de apropriação descrita acima - é referente ao compartilhar do espaço entre diferentes grupos e diferentes usos: seja para trabalho, lazer, circulação, cultos religiosos ou outros fazeres. Este compartilhar falará não apenas 
sobre um espaço rico em diversidade, mas, consequentemente, sobre um local conformado por consensos e dissensos, pela negociação cotidiana do uso do espaço comum.

São diversos os autores que falam sobre a questão da diversidade e de ser ela inerente ao espaço urbano (LEFEBVRE, 2006b; PARK, 1987; HARVEY, 2013a). Jane Jacobs, em seu livro seminal Morte e Vida das Grandes Cidades, defende que “a diversidade é natural às grandes cidades" (JACOBS, 2000, p.157) e seria revelada pela existência de um imenso número de elementos e a imensa diversidade desses elementos.

Como apontado a partir de Mello e Vogel (1985), a diversidade de elementos vistos em determinados locais - tal como o Catumbi e, segundo a hipótese colocada aqui, a Nova Holanda -, irá resultar em diferentes padrões de composição do espaço que irão se sobrepor. Neste contexto, as sobreposições que surgirão desta pluralidade, deverão encontrar negociações e acordos para sua coexistência:

Os recortes e as apropriações dos espaços, além de múltiplos, são não-exclusivos, o que quer dizer que muitas atividades podem coexistir no mesmo espaço, redefinindoo. Os sistemas assim concebidos têm a virtude de saberem conviver com a ambiguidade. Exemplifiquemos essa coexistência com seus eventuais efeitos negativos: as dissenções, interferências e conflitos. Como todas as fronteiras são definidas contextualmente, a única maneira de desfazer acavalamentos não desejados, ou de hierarquizar as diferentes formas de apropriação, tornando-as compatíveis, é a prática permanente da negociação. (MELLO et al., 1985, p.129)

A "prática de negociação" citada é, como mencionamos acima, parte da dinâmica espacial da Nova Holanda e consequência da pluralidade de usos e funções destinadas aos espaços.

Consideremos ainda a Figura 23, de Elisângela Leite. Na imagem, além de mostrar a questão da apropriação do espaço pelas crianças e da reivindicação do local como área de lazer, fala-se também sobre as negociações construídas entre vizinhos.

Apesar de as crianças e mulheres serem o tema da cena, Elisângela dá considerável importância ao contexto espacial através do enquadramento escolhido. $\mathrm{O}$ entorno do local onde a piscina está instalada é exposto através de sua composição. A piscina ocupa o centro da via. Ao fundo, a imagem nos revela o logradouro, com casas enfileiradas na típica tipologia construtiva da Nova Holanda. É possível ver motos paradas na frente das casas. Ao fundo, do lado direito da imagem, vemos uma 
grande tenda plástica montada, a qual Elisângela diz ser o "Pagode do Flavinho", evento que aconteceria às quintas-feiras.

Para além da ação dos personagens na piscina, as informações impressas na imagem nos revelam também um ambiente residencial, com circulação de veículos e no qual acontecem eventos culturais regulares. O uso da área comum aparenta ser plural. Ao ser perguntada sobre o compartilhamento do espaço e possíveis conflitos, Elisângela aborda questões sobre a dinâmica de uso do espaço:

São os próprios moradores [que definem a dinâmica/direção da rua]. É complicado. Os carros passam mais nas vias centrais. Essa daqui é um beco, né? São poucos os carros que entram ali, são mais para entregar alguma coisa, ou morador que vai parar na sua porta. Agora, moto, transita por qualquer espaço. Às vezes respeita, outras, não. Aí eles olham: se tiver uma brechinha aqui que dê pra passar, eles vão passar. Entendeu? Eu também entendo que é um absurdo fechar a rua e não deixar ninguém passar, nem um pedestre, nem uma bicicleta. Porque já aconteceu: de pedestre vir e não ter um espaço para passar. A rua é pública, então pode ter um pouquinho de consciência. Mas é complicado também, porque também tem que ter o espaço de lazer. Aí vou fazer o que? Vou usar a porta da minha casa, ou a laje, né?

Para além deste ponto, a fotógrafa fala sobre os acordos cotidianos e o provável motivador das negociações estabelecidas: os laços entre vizinhos e a convivência existente entre eles. Segundo a fotógrafa,

Aqui na favela, diferente de zona sul, a gente ainda tem o calor humano. Ainda tem aquela coisa de você sentar na calçada, conversar com o vizinho... e acho que a partir dessas relações que você vai formando... A vizinha aqui faz churrasco, usa a rua e fecha a rua. Ou então querem fazer um almoço de domingo... nesse domingo mesmo teve: ia chover, colocaram uma tenda, fizeram o almoço ali mesmo. Aí tem aniversário, ninguém reclama de fecharem a rua, colocarem som, fazem mesas, decorações... e fazem a festa. Acho que é a forma mesmo de estarem se conhecendo, de trocar as amizades, de estarem refinando suas amizades... trocando laços. É muito difícil você ver os vizinhos brigando. É muito laço, muito carinho. É uma família grande. $\mathrm{E}$ os acordos acontecem naturalmente.

Os valores apontados por Elisângela são semelhantes aos que Jacobs enfatiza em seu livro sobre a importância do contato nas calçadas das cidades:

A confiança na rua forma-se com o tempo a partir de inúmeros pequenos contatos públicos nas calçadas (...). Grande parte desses encontros é absolutamente trivial, mas a soma de tudo não é nem um pouco trivial. A soma desses contatos públicos casuais no âmbito local (...) resulta na compreensão da identidade pública das pessoas, uma rede de respeito e confiança mútuos e um apoio eventual na dificuldade pessoal ou da vizinhança. (JACOBS, 2000, p.60)

Assim como as imagens de Elisângela, fotografias de Bira que mostram espaços com usos transformados por intervenções de moradores, também apontam para 
negociações locais. Voltando à Figura 17, por exemplo, o ato de "ter a rua como sua" faz com que a tenda do culto evangélico transforme a função da via - uma rua de dimensão média, onde poderiam passar caminhões, por exemplo. Ao serem transformados em locais de interação e circulação de pessoas, os acordos passam a ser reestabelecidos. Como aponta Bira:

A rua rompe com isso [da rua ser o local onde transitam os carros]. As pessoas estão no meio da rua. E se divide esse mesmo espaço. Se empoderam, os pedestres. Isso devia ser ensinado em todo o Rio de Janeiro. Tinha que ser ensinado. Aqui, para os motoqueiros atravessarem, dá um problema danado. Mas duvido que alguém pediu para ficar aqui.

Para além da questão do fluxo e do trânsito, na Figura 17, o fotógrafo aborda também os acordos construídos pelos indivíduos que frequentam o entorno onde a intervenção temporária está instalada. $\mathrm{O}$ enquadramento feito por Bira coloca a tenda no centro da imagem, ocupando praticamente toda a composição: ela é, sem dúvida, o tema principal. Por outro lado, porém, o distanciamento que o fotógrafo toma do evento, possibilita que as fachadas das casas da rua apareçam no recorte, uma decisão que faz aparecer a integração da tenda - uma instalação temporária com o espaço construído local. As casas da imagem parecem "acolher" a estrutura de tecido. A tenda passa a fazer parte do espaço. As casas, que antes encontravamse em lados opostos de uma via, agora são os limites de um mesmo local.

O culto, porém, não é o único evento da rua. Ao lado esquerdo da imagem, um estúdio de tatuagem parece estar aberto. Também do mesmo lado, dois homens olham para a tenda, mas não parecem quererem aproximar-se e integrar-se do grupo. Entre a câmera que registra o momento e a tenda, uma rua vazia, o que nos faz pensar que talvez o evento não esteja tão cheio quanto se esperava ou que foi pensado para que os presentes fossem justamente aqueles que estavam sob a instalação. Neste contexto, tanto as casas e comércio ao redor, quanto as pessoas que não estão integradas ao grupo nos fazem refletir sobre os limites do espaço individual e coletivo daquele cenário. Ao ser perguntado sobre como era a relação entre vizinhos em eventos desta natureza (intervenções temporárias em espaços não destinados exclusivamente para tal uso), Bira aborda a questão supracitada sobre os acordos e dissensos existentes. 
Nem todo mundo gosta [de eventos na rua]. Uma mulher outro dia me falou: 'Ah, esses caras chatos! Não vou conseguir nem assistir à minha novela'. Mas vai fazer... E aí, vai tentar acabar cedo para não atrapalhar ninguém.

Entre as disputas pelo espaço, aparecem também os códigos de convivência que vão se estabelecendo nos tratos cotidianos, como também aborda Bira em outro exemplo ocorrido no mesmo local:

Agora está sendo montado um toldo que eu quase não consigo passar para chegar aqui ${ }^{119}$. Eu ia ter que dar a volta, aí o pessoal viu e tirou o negócio do caminho para eu passar.

Como apontam Mello et al. (1985), "na medida em que os usos variam, põem em funcionamento o circuito de relações que constituem a vida pública nos espaços de uso comum. Estas, por sua vez, alimentam a rede de crédito e confiança" (MELLO et al., 1985, p.130). E desta forma, apesar dos dissensos e possíveis conflitos, as negociações sobre o uso do espaço vão se constituindo.

Como descreve Harvey (2014), a heterotopia defendida por Lefebvre (2006b) - abordada no capítulo 2 - aponta para espaços sociais onde a possibilidade de "algo diferente" seria fundamental para suas trajetórias revolucionárias. Este "algo diferente" não viria necessariamente de projetos concretos e conscientes, mas sim, do "que as pessoas fazem, sentem percebem e terminam por articular à medida que procuram significados para sua vida cotidiana. Estas práticas criam espaços heterotópicos por toda parte" (HARVEY, 2014, p.22).

Em meio a tais espaço, a apropriação e o compartilhar irão pressupor disputas e acordos sobre seu uso. Os conflitos e dissensos fazem parte da essência do espaço urbano, como vimos no capítulo 2. E Rosilene, irá abordar a questão sobre algumas disputas pelo espaço como consequência dos múltiplos usos a partir da descrição da Figura 24.

119 Bira é cadeirante e referia-se ao acesso da cadeira de rodas. 


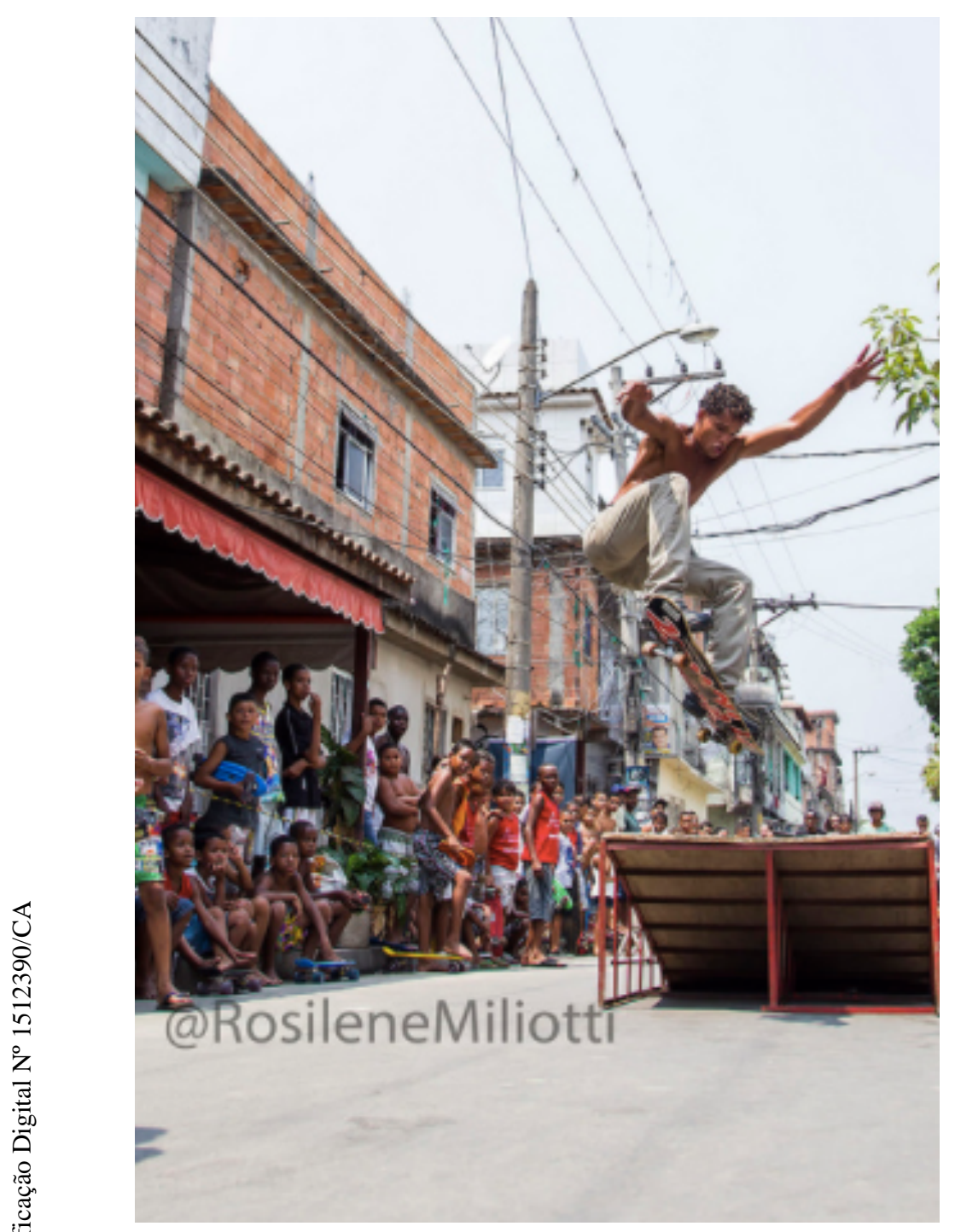

Figura 24 - Fotógrafa: Rosilene Miliotti

Esse daqui é um pessoal do long [long board, categoria de skate]. E eles têm uma questão muito sobre o uso da rua, do espaço. As ruas da Maré são lugares de disputa o tempo inteiro. Você tá ali entre carro, caminhão, moto, bicicleta, pessoas querendo andar... é todo mundo disputando aquele espaço, porque as calçadas não existem. E essa galera do long, a gente começou a perceber que tinha um movimento principalmente depois do exército. $\mathrm{O}$ que aconteceu foi que antes do exercito entrar, a gente via um movimento de moto muito grande, era uma loucura: você colocava o pé na rua, tinha que tomar cuidado para as pessoas não passarem em cima do seu pé. E aí, quando o exército entrou, essas motos sumiram. Então a rua ficou "limpa", você conseguia andar na rua. E aí começou a aparecer um pessoal de long, ou então naqueles skates pequenininhos de plástico para cima e pra baixo.

A presença dos skatistas na rua representou para a fotógrafa a reivindicação pelo espaço feita pelo grupo. Ao entendê-lo também como "seu”, os skatistas se organizaram para fortalecer o movimento local. O registro de Rosilene mostra o encontro idealizado pelos jovens: 
Tem esse grupo aqui, o Maré Long Board. E aí eles fizeram um evento, contaram com o apoio de algumas pessoas, fizeram camisas... e era a disputa de manobras. Conseguiram fechar a rua, esse dia foi muito legal. E tinha uma molecada em volta, todo mundo olhando. Tinham meninas, meninos, adulto, mulheres... ou participando, ou assistindo. Eles que fizeram, não tinha apoio de organização nenhuma. Eles pediram autorização pro exército, fecharam a rua, tudo direitinho. E eles também vão para outras comunidades, outros bairros para poder participar de outras disputas.

$\mathrm{Na}$ imagem vemos um jovem que, ao saltar de uma rampa com o skate, "voa" em uma manobra. Ao redor, muitos outros jovens - dentre os que são possíveis contar, cerca de quarenta -, diversos deles ainda crianças, muitos com os seus próprios skates. Todos os presentes direcionam seu olhar para aquele que faz a manobra. $\mathrm{O}$ evento montado no centro da rua parece não só transformar o uso do espaço, mas também inspirar os meninos, construindo o desejo de também conseguir fazer o mesmo um dia.

Organizado pelos próprios skatistas e moradores, o evento, que possibilitaria trocas entre pessoas de perfis distintos e de diferentes regiões da cidade, parece trazer algo inusitado ao local, diverte e surpreende as crianças com uma nova possibilidade que se apresenta no espaço. Para Rosilene, porém, o principal tema de sua representação é a disputa que se estabelece pelo espaço da rua.

Hoje em dia deu uma diminuída, porque as ruas voltaram a serem ocupadas por motos e muitos carros, mas esse foi um período muito legal deles: deles estarem ocupando a rua. E começou muito essa discussão, sobre a disputa pelo espaço da rua, o que chamou muito a atenção da gente sobre o espaço da rua.

Ao aprofundar-se na questão, Rosilene aponta haver uma grande diferença entre as funções destinadas à rua pelos moradores da Nova Holanda. Em sua visão, há uma considerável disputa nas vias de grande fluxo, tal como a Teixeira Ribeiro ou a Principal. Porém, não em ruas estreitas como a da foto de Elisangela (Figura 23) ou de seu registro da Figura 18. Sua fala sobre a questão demonstra uma percepção natural sobre a função de espaços comuns como as vias onde se concentram as unidades residenciais.

Quando eu falo sobre a disputa, eu falo sobre esse espaço, dessas ruas que são largas e que as pessoas não conseguem circular mesmo pela quantidade de carro, moto... e tem que ter atenção, cuidado, com isso e aquilo. É isso. Esse é o lugar de disputa. A Principal, por exemplo, é uma loucura. A Teixeira Ribeiro é uma loucura. Quando tem caminhão para fazer entrega em um dos mercadinhos ali, nada passa. Os carros estacionados, aquele lugar pra entrar e sair, as pessoas sem lugar pra entrar, é bicicleta querendo passar, é moto querendo passar... é skate querendo passar.. esse 
é o lugar de disputa... pelo menos é assim que eu percebo. As ruas pequenas, eu não vejo como um lugar de disputa. É um lugar de encontro, talvez.

O entendimento sobre as ruas de pequeno porte serem um local de "encontro", nos remete novamente à colocação de Jacobs (2000) sobre a questão da confiança que se constrói a partir dos contatos casuais no espaço comum.

Sobre esta questão, vale pontuar um outro elemento abordado durante as entrevistas em relação ao "compartilhar" do espaço. Assim como a fala de Elisângela sobre a boa relação entre vizinhos, Rosilene também abordou a questão das trocas, do "crédito" e da "confiança" construída ao falar sobre a Figura 25.

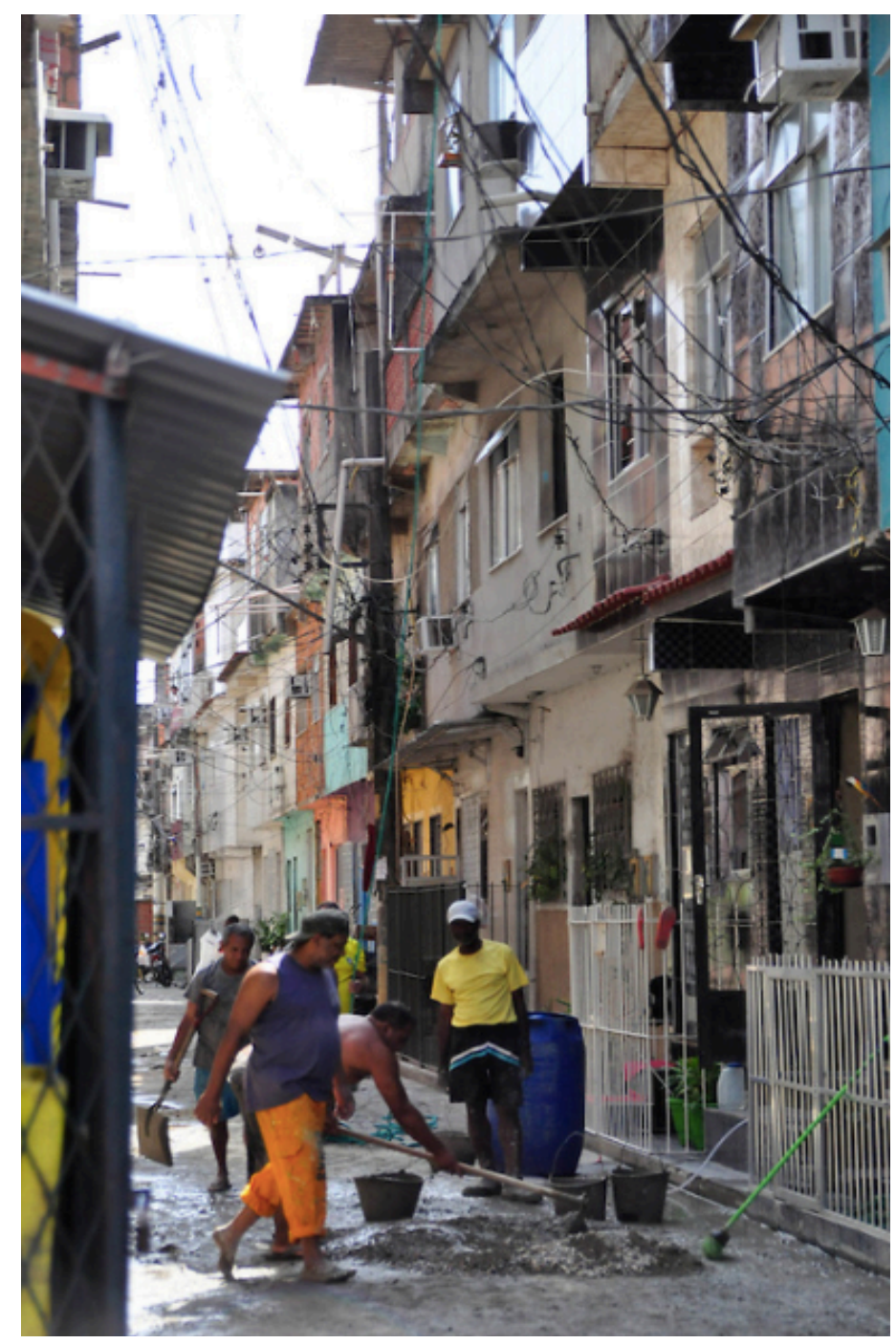

Figura 25 - Fotógrafa: Rosilene Miliotti

Os pontos colocados aqui tangenciam a discussão sobre a noção de "comunidade", pontuada por diferentes autores. É certo que a questão do vínculo entre moradores 
não pode ser generalizada, porém tanto Elisângela quanto Rosilene, apontaram tal questão como característica representativa da Favela Nova Holanda.

Na Figura 25, Rosilene procura representar a confiança e a relação de troca existente entre os moradores. Nela, quatro homens mexem em materiais de construção no centro de uma rua da Nova Holanda. Baldes, pás e a mangueira que sai de uma das casas são usados para fazer a mistura que será usada em uma provável obra. "Bater laje" é conhecido como um antigo processo de construção de casas em áreas populares, na qual vizinhos se juntavam para construir partes da casa de alguém. Apesar deste ter sido um processo comum durante muitas décadas, hoje em dia, em muitos lugares, já não é mais utilizado. Os moradores preferem contratar quem faça o serviço ao invés de organizar o mutirão.

A imagem de Rosilene que, pelo enquadramento e postura dos personagens parece ser quase um "flagrante", registra um desses momentos. Ao falar sobre a fotografia, Rosilene aborda a questão sobre a ajuda mútua que aconteceria entre os vizinhos da Nova Holanda.

Acho que essa foto representa bem a questão da comunidade. Hoje, até que tem menos essa coisa de bater a laje, pra virar a laje, pra fazer alguma coisa de obra. A gente já vê alguns moradores contratando aqueles caminhões de cimento. Mas na Nova Holanda ainda tem disso, das pessoas se juntarem. Às vezes as pessoas se juntam no domingo e aí você percebe que elas são amigas e juntaram ali e vão fazer por um prato de macarrão, um churrasco ou uma feijoada. Ainda tem isso dos amigos se juntarem pra fazer alguma coisa. Em alguns lugares menos, mas na Nova Holanda, que era onde eu circulava mais, eu via. E era de se juntar desde pra ajudar alguém que precisava ser enterrado, porque não tinha dinheiro, até isso: de virar laje, enfeitar uma rua, fazer festa de aniversário para alguma criança... 'ah, não posso dar dinheiro.' 'Então você pode fazer o que? dar um litro de leite, ajudar em alguma coisa?' Então esse sentimento, essa coisa de comunidade... tem essa coisa.

A questão da ajuda entre vizinhos estaria ligada, segundo Rosilene supõe, à proximidade entre as pessoas. Não seria apenas uma questão de solidariedade, mas sobre ajudar quem precisa e que é próximo.

As pessoas têm essa coisa de comunidade, elas se ajudam, né... claro, a gente percebe assim: eu ajudo quem precisa, quem eu vejo que realmente merece... então eles se ajudam muito entre os próximos. De repente, eu posso tá falando alguma besteira... mas dificilmente você vai ver as pessoas não se conhecerem e ajudarem alguém... da Vila do João. Não porque sejam de facções diferentes! Mas porque não tem proximidade. Então ali, quem tá próximo, é realmente próximo. E ajudar, é isso: desde ajudar com comida, quem tá passando necessidade, até ajudar na casa, ajudar a pintar... ainda tem bastante ali. 
A fala de Rosilene traz a questão sobre a proximidade entre os moradores da Nova Holanda: "Quem está próximo, é realmente próximo". Tal proximidade irá, assim, influenciar diretamente não só na ajuda mútua em situações de cooperação, mas também no construir e no vivenciar do espaço comum. Elisângela, ao falar sobre os "laços" que se constroem entre os vizinhos e o "calor humano da favela" que influenciariam nas negociações estabelecidas cotidianamente, igualmente está abordando tais questões.

\subsection{3}

\section{Espaço dinâmico}

Para além do "apropriar-se" e do "compartilhar" do espaço, uma terceira característica foi abordada em diferentes momentos das entrevistas: falou-se sobre a Nova Holanda ter o forte caráter de ser um espaço orgânico, o qual transforma-se constantemente através de pequenos períodos de tempo e em diferentes dimensões. As mudanças se dariam tanto na esfera social, quanto física, podendo estas serem alterações temporárias ou permanentes. Falou-se sobre mudanças significativas no espaço social que ocorrem ao longo do dia (os quais Bira chama de "ciclos" ou "turnos"). Foi mencionado também como a diversidade de ações em áreas determinadas fazem das ruas um espaço plural e vivo. Sobre o espaço físico, falouse sobre as transformações constantes no espaço construído para fins comerciais ou para melhorias das casas para o próprio núcleo familiar. Intervenções temporárias para o lazer - tal qual as apresentadas acima - também foram citadas como apropriações que influenciam no caráter dinâmico do espaço, na característica de apresentar-se em um constante transformar.

Antes de nos aprofundarmos em tais aspectos, cabe pontuar os "motivadores" apontados como responsáveis por tal característica do espaço. Falou-se sobre o valor dado pelos moradores à vida na rua (questão tratada no item 4.3.1). Abordouse também a pluralidade característica dos usos e dos habitantes que compartilham o mesmo espaço (questão tratada no item 4.3.2). Apontou-se ainda para a importância dos habitantes na construção do espaço. Tratou-se de como o encontro e as trocas entre moradores que se dão nas ruas da Nova Holanda contribuem para o caráter de espaço orgânico, vivo. 
O encontro, importante salientar, seria uma das características cruciais ao espaço comum da cidade, segundo autores como Lefebvre. Tal como visto a partir do capítulo 2, a crítica do sociólogo francês, ainda pertinente hoje, coloca que no pensamento da cidade moderna, esta essência da rua passaria a ser completamente suprimida. Ela perderia seu caráter de lugar do encontro, do movimento e da mistura, sua função simbólica, lúdica, do espaço que informa e surpreende. A rua se tornaria, a partir do modernismo, o espaço do fluxo dos automóveis e da mercadoria, servindo exclusivamente ao novo modelo de vida dominante na sociedade - o espetáculo (Lefebvre, 2004). Ao falar sobre a essência da rua, Lefebvre aponta para alguns de seus aspectos:

A rua? É o lugar (topia) do encontro, sem o qual não existem outros encontros possíveis nos lugares determinados (cafés, teatros, salas diversas). Esses lugares privilegiados animam a rua e são favorecidos por sua animação, ou então não existem. Na rua, teatro espontâneo, torno-me espetáculo e espectador, às vezes ator. Nela efetua-se o movimento, a mistura, sem os quais não há vida urbana, mas separação, segregação estipulada e imobilizada. (...) Nela joga-se, nela aprende-se. A rua é desordem? Certamente. (...) Essa desordem vive. Informa. Surpreende. (...) $\mathrm{Na}$ rua, e por esse espaço, um grupo (a própria cidade) se manifesta, aparece, apropria-se dos lugares, realiza um espaço-tempo apropriado. Uma tal apropriação mostra que o uso e o valor de uso podem dominar a troca e o valor de troca. (...) O espaço urbano da rua não é o lugar da palavra, o lugar da troca pelas palavras e signos, assim como pelas coisas? (LEFEVBRE, 2004, p.29-30)

O trecho de "A Revolução Urbana" (LEFEBVRE, 2004) nos remete a diferentes imagens e falas expostas até aqui: aponta para a questão da apropriação do espaço por grupos, fala sobre a mistura, a surpresa. Tal como em Lefebvre (2004), a rua para Bira é o lugar onde se aprende:

É o local dos encontros, o local das lembranças, mas também uma grande escola. Um grande mestrado. Porque eu descubro todos os conceitos, todos os saberes do que está ali. Perpassam por mim e param.

Outra colocação de Bira, já apontada anteriormente, sobre o entendimento da rua como quintal, na qual o espaço é compreendido como "próprio", é também comum ao texto de Lefebvre. O caráter de "encontro" supracitado e abordado em diferentes momentos durante as entrevistas - tanto por Rosilene quanto por Elisângela -, é novamente colocado por Bira:

A rua é muito isso: é encontro. Encontro de pessoas diversas, de grupos diversos, que têm muito em comum. Sou fotógrafo, paro para conversar com traficante, com cristão, com o rapaz do mototaxi... fico ali. 
Sobre a importância dada à rua e sua influência para a troca no espaço, Bira faz um relato interessante a partir da Figura 26. Nela, aborda como tal valor influenciaria na conformação física de espaços privados, tornando-se um "valor agregado" ao local - noção que também se aproximaria à colocação de Lefebvre.

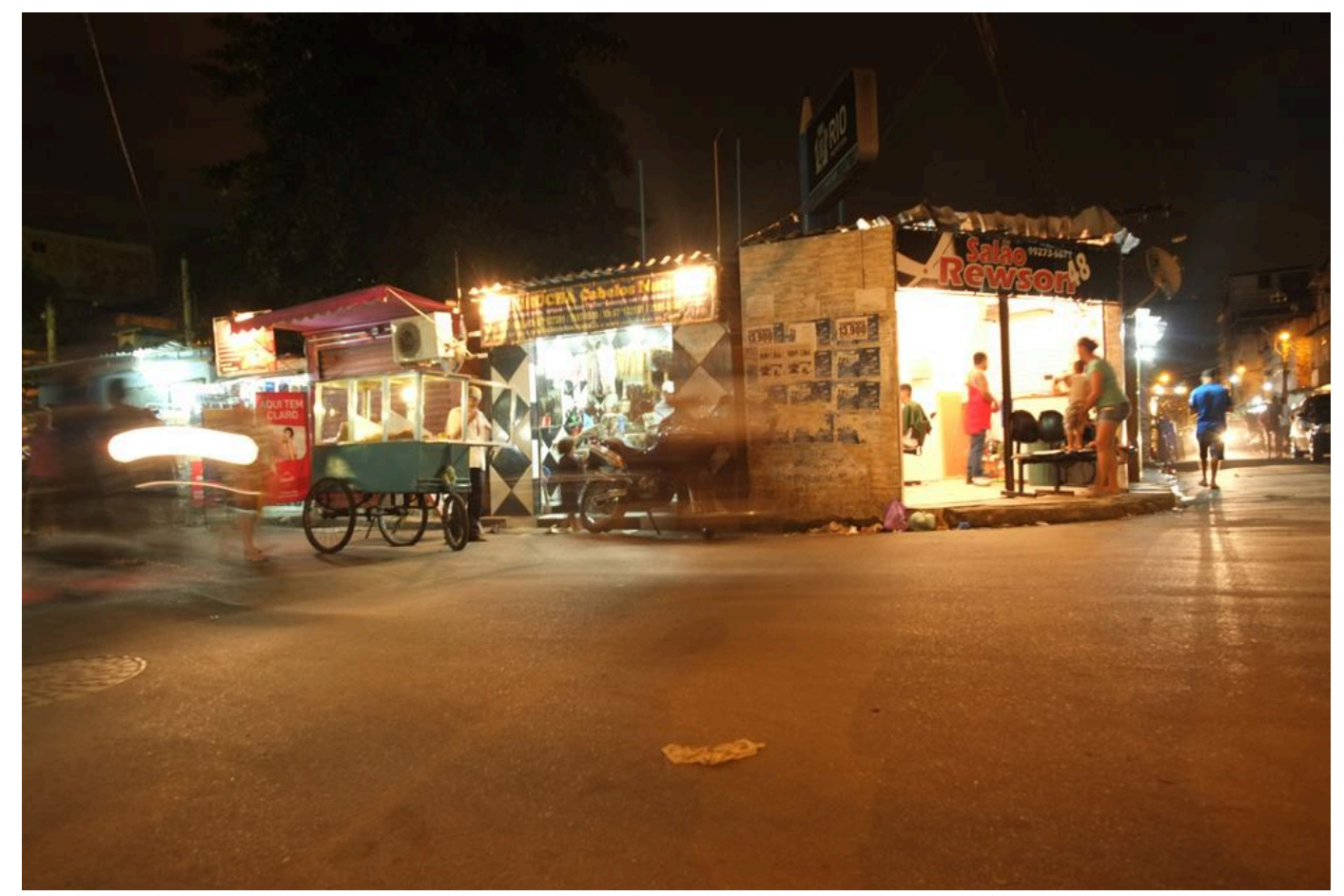

Figura 26 - Fotógrafo: Bira Carvalho

A fotografia é tirada de uma esquina, de onde se mira o outro lado da rua. Feita em uma exposição de tempo longo, a imagem traz a ideia de movimento e vida intensa em uma rua iluminada em meio a uma noite de céu escuro. Do lado esquerdo para o centro, vê-se um vulto, provavelmente de uma motocicleta que passava rapidamente naquele momento (conclusão tirada pelo rastro de luz que se nota); neste mesmo lado da imagem, é possível ver pessoas na rua. No centro da imagem, lojas - todas construções de um pavimento -, um pipoqueiro e uma motocicleta estacionada. É possível identificar outras pessoas espalhadas e envolvidas em diferentes atividades. A vitalidade da rua é um tema que se destaca na imagem, característica esta que seria marcante na Nova Holanda, segundo relato dos três fotógrafos.

Para além de tal elemento, o salão da esquina - chamado "Rewson" - nos chama a atenção: ele seria, aqui, o nosso puctum. Sua fachada é composta por um grande vão; as cadeiras de espera para atendimento estão posicionadas junto à fachada e 
viradas para a rua, entre o meio-fio e a porta. Como aponta Bira, o salão tornou-se referência na Nova Holanda por causa das constantes intervenções que o barbeiro fazia no espaço. Segundo o fotógrafo, seria comum a diferentes favelas terem barbearias como ponto de encontro ${ }^{120}$. A barbearia da imagem seria a "sua" barbearia, onde o corte de cabelo semanal tornava-se motivo para confraternizar com um grupo de amigos que, de forma espontânea, encontravam-se no local sem que houvesse nada marcado.

A barbearia, um estabelecimento comercial para corte de cabelo, torna-se um ponto de encontro, abrangendo assim uma função além da destinada originalmente a ela. A área útil do salão, uma sala alugada, se expande para a rua através das cadeiras de espera, integrando-se ao espaço comum e abrindo-se para os transeuntes que ali circulam. Neste contexto, o espaço privado não é visto apenas como um local para permanência interna. Estar do "lado de fora" parece ser algo desejado pelos que frequentam o espaço. Enquanto em outras áreas da cidade entrar em uma loja ou em estabelecimentos comerciais e de serviços é manter-se em um local fechado, restrito a alguns poucos que também podem/querem estar ali, na barbearia em questão a abertura para a rua agrega valor ao local, uma característica que parece alinhar-se à lógica apontada por Lefebvre no trecho supracitado: "Esses lugares privilegiados animam a rua e são favorecidos por sua animação, ou então não existem" (LEFEVBRE, 2004, p.29). Segundo o relato de Bira:

Ele [o barbeiro] foi evoluindo: depois dessa foto, ele colocou fliperama, botou máquina de música... e aí ele começou a ser o barbeiro mais cogitado da favela. Ele tem um tino de negócio muito bom. O que ele fez aqui [na imagem]? Ele tornou esse espaço mais agradável, ele virou o espaço para a rua. O que é mais agradável em uma viagem de avião, ir na janela ou no corredor? [na janela] Então... é isso que ele fez aqui. Toda sexta-feira a gente ficava lá, todo mundo.

A rua na Nova Holanda mostra-se nas imagens e relatos como o "lugar da troca pelas palavras", da desordem que informa e surpreende. Ainda segundo Bira:

As trocas acontecem naturalmente. E por isso que é maneiro. Uma hora eu estou conversando sobre uma coisa, e aí chega outro e já muda o enredo da conversa, e aí chega outro, chega outro... e aí as memórias já vão brotando... as risadas... Ontem eu voltei pra casa eram duas da manhã... chovendo... porque meia noite cismamos

120 Bira menciona o filme "Deixa na Régua", de Emilio Domingos, documentário no qual fala-se sobre a expansão de salões de barbeiro nas favelas e subúrbios cariocas. Segundo a sinopse do filme: "Ponto de encontro dos jovens, os "barbeiros" se tornaram espaços de troca dessa juventude". 
de jantar. Fomos jantar e ficamos conversando. Ai uma hora, eles conversando e eu, "pá"... só escutando... e aí chegou vários outros de outros grupos, de várias favelas.. e aí eu fui dormir pensando: "caraca... se daqui a 50 anos, se eu não registrar isso, ninguém vai acreditar na quantidade de gente que eu conheci, de grupos diferentes, tão diversos".

Para Bira, seria a partir de tais trocas que surgiria o espaço conforme ele se apresenta; uma configuração que resulta de uma rua de vida intensa, frequentada por pessoas profundamente distintas entre si:

Esse espaço de troca é muito dinâmico, muito valioso. Ele faz o espaço ser o que é. (...) O conhecimento oral também é assim. É como o Ioruba, que se fala na Bahia. Uma língua que vem da África, que se usa no Candomblé. Como é que essa língua vai mudando, vai se projetando, se transformando... parte dela vai perdendo o sentido ou se transformando em outro sentido. E então a rua para mim é isso.

A fala de Bira remete ao pensamento de Michel De Certeau (apud MELLO \& VOGEL, 2005), "tal como o ato de falar cria a língua, os (a)fazeres cotidianos efetuam o espaço". E, indo ainda além, Bira coloca a rua como uma construção coletiva que se sobrepõe ao longo dos anos a partir das trocas de quem a vivencia.

É muito viva a favela. Ela vai se transformando. E o fato de estar muito na rua, permite que os grupos mantenham essa relação humana. É o que está no Baixo Gávea, no jogo do Flamengo, Lapa... não chegamos em tanta diversidade quanto a Lapa, mas a Nova Holanda tem esse formato das pessoas estarem na rua, estarem para lá e para cá desfilando.

As relações de convívio entre pessoas distintas na rua fazem a Nova Holanda ter as suas próprias características, conforma o uso dos espaços que podem ser ora próprios para passagem de carros, ora para palco de eventos ou destinado ao uso de piscinas de plástico: as interações sociais que se constroem, transformam os espaços comuns dando-lhes vida e organicidade.

A rua da Nova Holanda seria, assim, constantemente (re)composta por tal pluralidade de encontros e trocas que o espaço comum possibilita. Rosilene Miliotti, ao falar sobre a Figura 27, também aborda tal questão. 


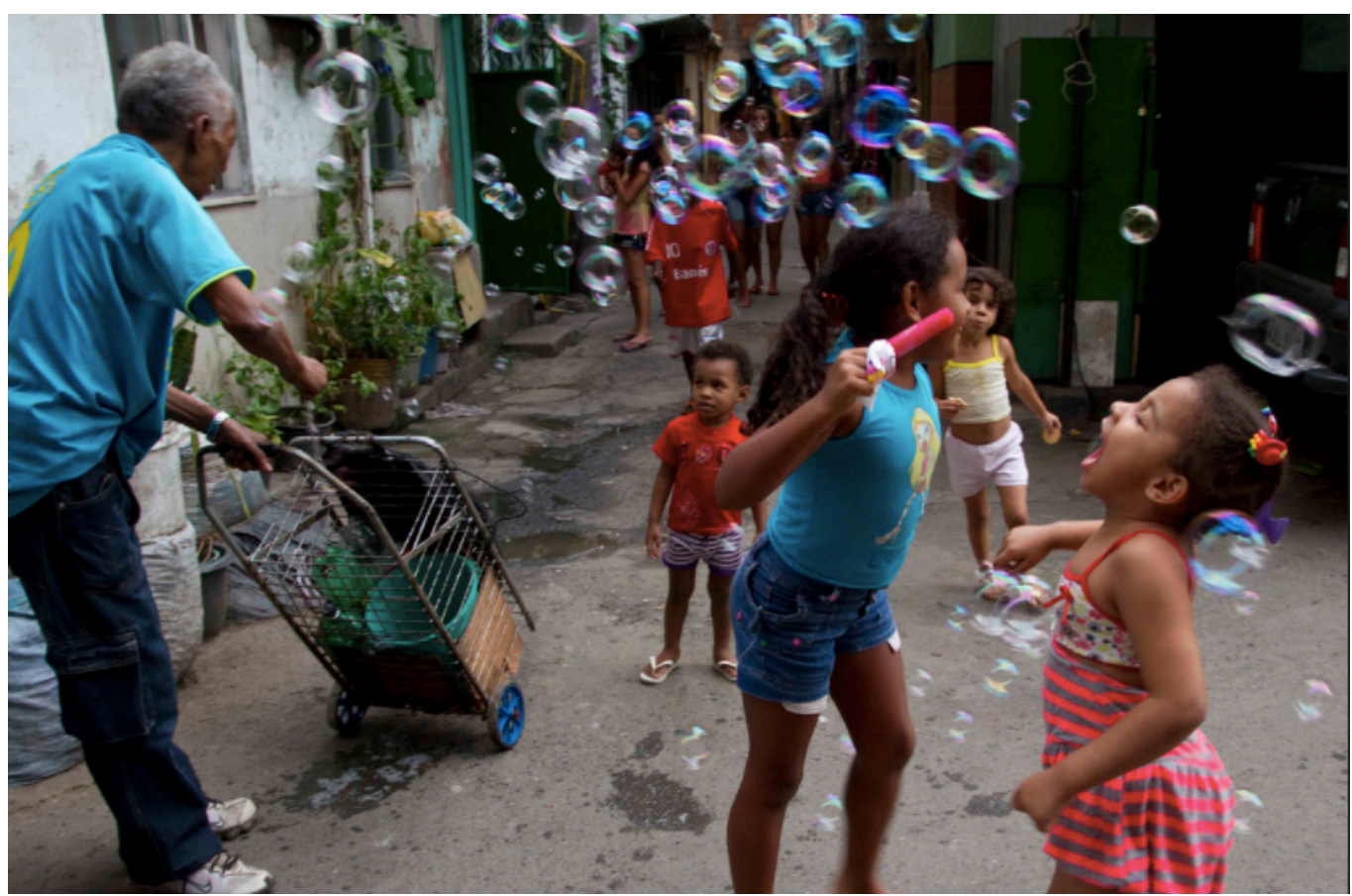

Figura 27 - Fotógrafa: Rosilene Miliotti

A imagem registra o trabalho de Seu João Bolinha, um morador aposentado que vive na Nova Holanda desde sua fundação. Segundo Rosilene, ao fim do dia, principalmente nos fins de semana, o idoso sai pelas ruas da Maré fazendo bolinhas de sabão e vendendo o "kit" para a brincadeira (o qual ele mesmo produz) por um Real. Seu João Bolinha faz parte da memória e da identidade da Nova Holanda (e da Maré), segundo Rosilene. Seu trabalho, através de um gesto tão curto e singelo transforma não só o espaço ali vivido, mas também transporta os moradores adultos à Nova Holanda de outros tempos. A dimensão temporal do espaço - abordada por Lefebvre (2006a) - é modificada através das bolinhas que estouram no ar. Ver seu João em seu tradicional trabalho conectaria não só diferentes gerações, mas também grupos distintos.

Eu conversei com três pessoas já adultas e eles disseram que desde criança conhecem o seu João Bolinha. Também chamavam ele para fazer festa... pra ficar soltando bolinha de sabão, colocar copo com detergente para as crianças... e ele fazia a animação da festa, né? Fazia isso e ganhava um dinheirinho com isso... é o trabalho dele e ele sempre pareceu muito feliz fazendo isso. E as pessoas com quem eu conversei sobre ele, tinham uma memória afetiva muito boa sobre a infância, com ele passando na rua. E isso, assim, foram três pessoas que falaram: uma pessoa envolvida com tráfico, uma senhora já com os filhos todos criados e outra adolescente. Então pessoas completamente diferentes tendo essa memória dele, entendeu?

Em contraponto às imagens de violência que se veiculam sobre a Nova Holanda, $o$ registro de bolinhas de sabão e crianças mostra um espaço com esfera de sonho. As 
bolinhas falam sobre o lúdico, sobre encantamento com o singelo. A fotografia capta um local com ar de magia, de pureza, de inocência. E a fotógrafa, ao destacar tal aspecto da cena, mostra não só a pluralidade de usos e características existentes nas ruas da Nova Holanda, mas pretende destacar que a realidade é distinta da veiculada comumente.

Quando a gente vai andando, você anda e você vê gente armada, mas você vira uma esquina e tem criança jogando futebol, vira na outra, tem criança correndo atrás de bolinha de sabão, sabe? Tem pessoas na calçada conversando, senhoras fazendo tricô... tem uma vida tão plural, tão diferente. Então, quando você vai vendo que cada esquina é uma coisa, não tem como você não registrar isso, esse cotidiano. A gente que mora, ser taxado só como um lugar de violência, só, incomoda bastante...

A fala de Rosilene sobre seu João Bolinha nos remete ao que também fala Bira Carvalho em diferentes momentos de sua entrevista: as pessoas e as trocas/encontros que acontecem no espaço é o que fazem a Nova Holanda ser o que é. Recorrentemente, fala-se como a relação pessoal/social entre os moradores é importante no "construir" constante do espaço. Bira, em sua página de Facebook, criou pastas de fotos dos "crias" - aqueles que nasceram na Nova Holanda - e dos "relíquias" (chamada "um salve aos relíquias da favela") - pessoas que há décadas vivem lá ou que frequentavam o local - e que, segundo Bira, "foram os que construíram a Nova Holanda". Durante toda a entrevista, o fotógrafo menciona como os moradores são a essência do lugar.

Como apontado anteriormente, as trocas, os encontros, a vida intensa na rua e a presença dos "crias" e "relíquias" seriam questões que motivariam o espaço a ter o caráter dinâmico, orgânico. Através de outras imagens e relatos dos fotógrafos, vemos algumas das transformações que se desenrolam no espaço a partir de tais elementos.

A Figura 28, de Elisângela Leite, e a Figura 29, de Rosilene Miliotti, mostram alguns aspectos sobre as transformações temporárias que teriam como intuito, mais uma vez, o encontro e o lazer, funções vastamente abordadas até aqui. As intervenções, novamente, transformam o espaço e dão novas funções à rua a partir das relações sociais construídas através da troca, do apropriar-se e do compartilhar do espaço. 


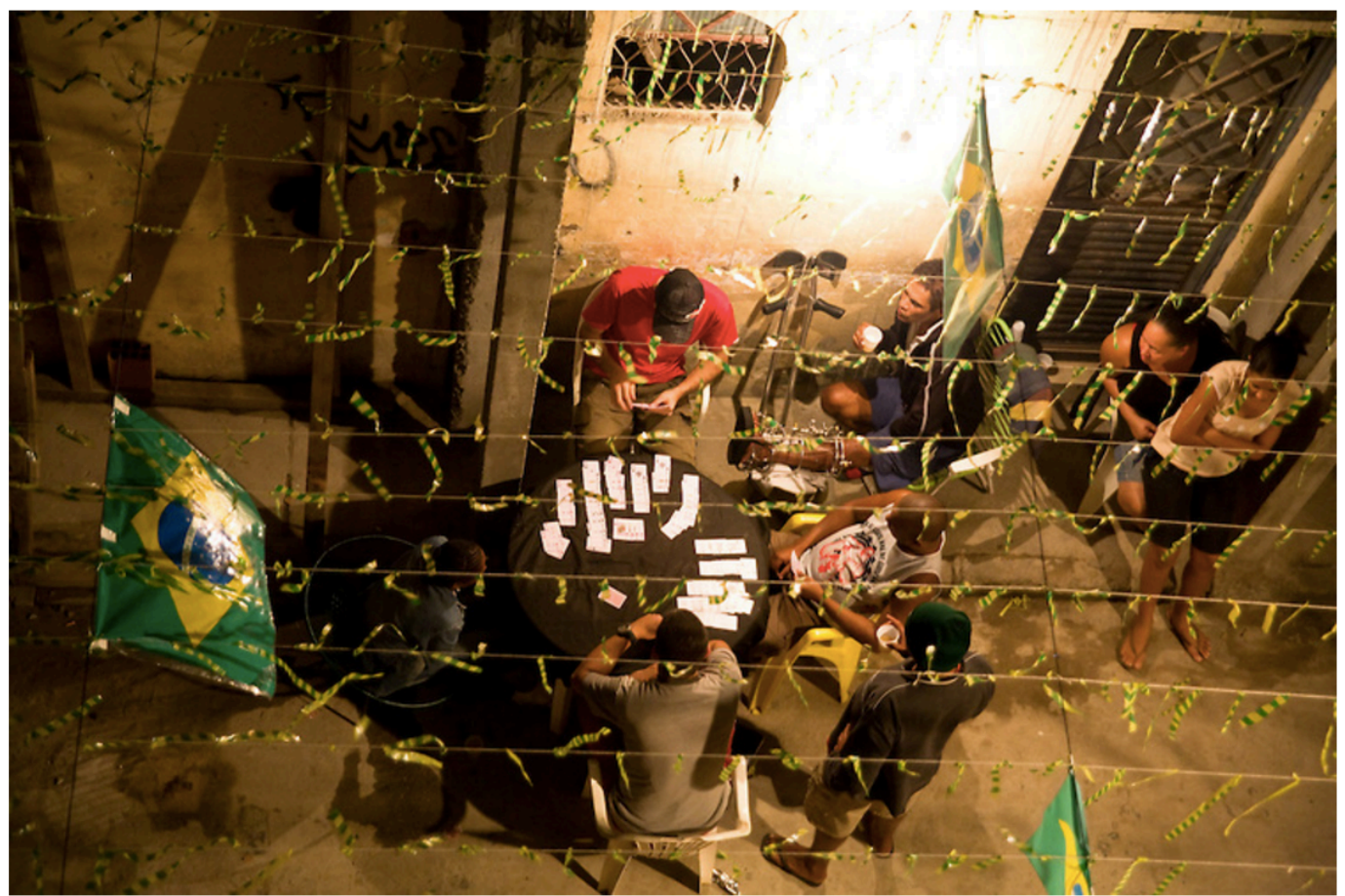

Figura 28 - Fotógrafa: Elisângela Leite

A Figura 28 mostra pessoas jogando cartas em uma mesa montada próxima a uma casa. Em torno dela, além dos participantes, vemos também pessoas assistindo. Este fato nos faz pensar que talvez o motivo da reunião não seja apenas o jogo, mas também sobre "estar junto". Ao ser perguntada sobre o que havia chamado a atenção para fazer o registro, Elisângela responde:

A composição, né. As bandeirinhas do Brasil: olha como o brasileiro é, que se diverte com tudo, né? Como o brasileiro é alegre, não tem tempo ruim. Estava frio na época. Olha, era noite... e estavam tomando a cervejinha e jogando as cartas. Aí eu olhei [a fotografia foi tirada da janela de sua casa]: fotinha! Precisa registrar o cotidiano, mostrar que a favela se diverte de todas as formas, que não tem tempo ruim.

O espaço parece ser genuinamente apropriado pelos moradores, uma questão não só percebida pelo enfeitar através bandeirolas do Brasil fixado na parte superior das casas, como também pela mesa e cadeiras levadas à rua e que tornam o local um espaço de confraternização.

A rua registrada - onde Elisângela mora - é o mesmo logradouro onde o menino da Figura 4 joga ping-pong. Assim como outras tantas imagens expostas aqui, aquele local provavelmente tomará outra forma e aparência em um momento posterior breve. 


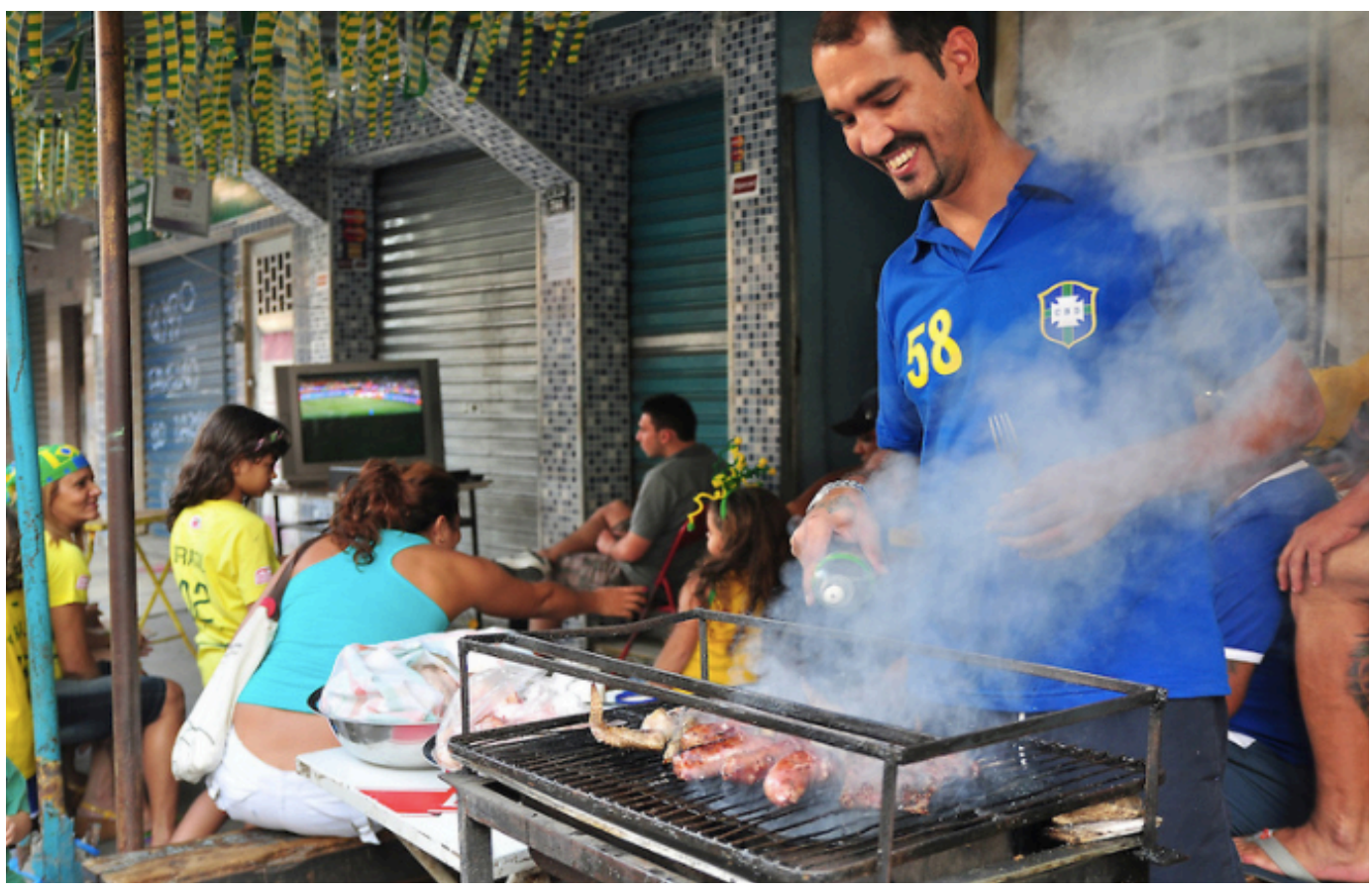

Figura 29 - Fotógrafa: Rosilene Miliotti

A transformação do caráter da rua é visto também na Figura 29, de Rosilene, na qual registra a rua Teixeira Ribeiro, a maior via da Nova Holanda. Ainda sobre o ensaio feito na Copa do Mundo de 2010, a fotógrafa aponta não só as conformações rotineiras do espaço, mas também o uso que ganha na ocasião especial:

Eles moram nessa porta daqui. Aqui na Teixeira Ribeiro, as calçadas são muito largas, e a rua estava vazia, acho que era domingo. O comércio na Teixeira é enorme, e ele começa bem cedo e acaba bem tarde. Quando você vê durante a semana, você nem percebe que a calçada é tão grande, porque ela está tão cheia de coisa... mas aí ele colocou churrasqueira, aqui atrás tinha um sofazinho, e tinham duas crianças deitadas... estava maior zona, pessoal vendo o jogo, uma gritaria, e elas lá... dormindo como se nada estivesse acontecendo!

Entre eventos de ocasiões especiais, encontros rotineiros ou intervenções esporádicas, o espaço vai adquirindo distintas conformações e propósitos. Em meio a ruas decoradas e estruturadas para eventos/usos pontuais tais como as fotos apontadas, não poderíamos dizer que o espaço é entendido através do valor de uso, visto como obra? Elisângela Leite, ao falar sobre a motivação de se intervir no espaço comum, principalmente em momentos de enfeitar a rua para ocasiões como a Copa do Mundo, aponta para a relação com o desejo do encontro e da confraternização:

Acho que é mais pela diversão sabe? De ter o espaço de se divertir, de fazer o churrasco, de se encontrar... de achar que a rua está mais bonita, está colorida, está cheia de vida. Acho que é mais isso. Pelo encontro, pelas amizades. É um motivo de 
fazer um churrasquinho, de beber sua cerveja. Às vezes eles colocam uma TV e ficam jogando vídeo game.

Importante frisar que o caráter "orgânico" do espaço não é visto apenas através da apropriação para a confraternização e o lazer. Como mencionado anteriormente a questão da pluralidade de usos através dos quais o espaço é utilizado: trabalho, cultos religiosos, entre outros. Dentre eles, é possível destacar através dos relatos e imagens de Bira como a motivação econômica têm sido um importante fator de intervenção no espaço, tanto na esfera física quanto social.

$\mathrm{O}$ que é diferente aqui, acho que é isso: das pessoas na rua. E com isso vem o comércio. Criou uma demanda de comércio na rua até mais tarde. E da demanda, virou uma oferta. Hoje aqui também tem o baile da Nova Holanda que é "o" baile do Rio. O baile em favela hoje no Rio é o da Nova Holanda. Vêm 10 a 12 mil pessoas. Já se criou uma demanda de transporte alternativo. As pessoas começaram a colocar barracas até na passarela, porque as pessoas passam e já compram lá e vão tomando.

Bira nomeia uma de suas pastas de imagens do Facebook como "Um fervo chamado Nova Holanda". Rosilene, ao falar sobre o movimento das ruas da favela também menciona a intensa vida cotidiana: "A Nova Holanda é ligada no 220v. Não para nunca!". Ao abordar a questão, Bira fala sobre sua percepção em relação aos "turnos" do cotidiano, principalmente sobre aqueles traçados pelos trabalhadores - sejam os que saem da Maré para trabalhar ou estudar em outras áreas da cidade, seja por aqueles que trabalham internamente. Segundo Bira, os "turnos" na Nova Holanda mudariam consideravelmente a conformação social do espaço. Ainda a partir da Figura 26, Bira diz:

\begin{abstract}
A favela é muito temporal. E tem uma mudança muito grande da noite para o dia também. Eu fico parado na favela, muitas vezes escutando música. E eu percebi como é que vai mudando esse processo [do movimento das ruas ao longo do dia]. Esses caras aqui são trabalhadores exclusivos da noite. O pipoqueiro, o milho... tem coisas que são da noite. É um outro processo. Os bares começam a abrir, a boca começa a passar de tarde para noite... É um outro contexto, e que eu nunca tinha registrado. Há um ciclo de horário: de manhã é um comércio, são pessoas que estão desempregadas e que vendem café da manhã: café, chocolate, pão, bolo... no meio da rua, no caminho.
\end{abstract}

A Figura 30, também de Bira Carvalho, registra os trabalhadores de um dos "turnos" da Nova Holanda. A cena se passa no fim de tarde, em uma rua que seria de médio porte mas não muito movimentada (ao menos naquele momento). À esquerda, um homem carrega um carrinho de mão repleto de objetos. À direita, outro homem que 
aparenta ser um vendedor ambulante de alimento; em seu guarda-sol, fotografias de pontos turísticos do Rio de Janeiro.

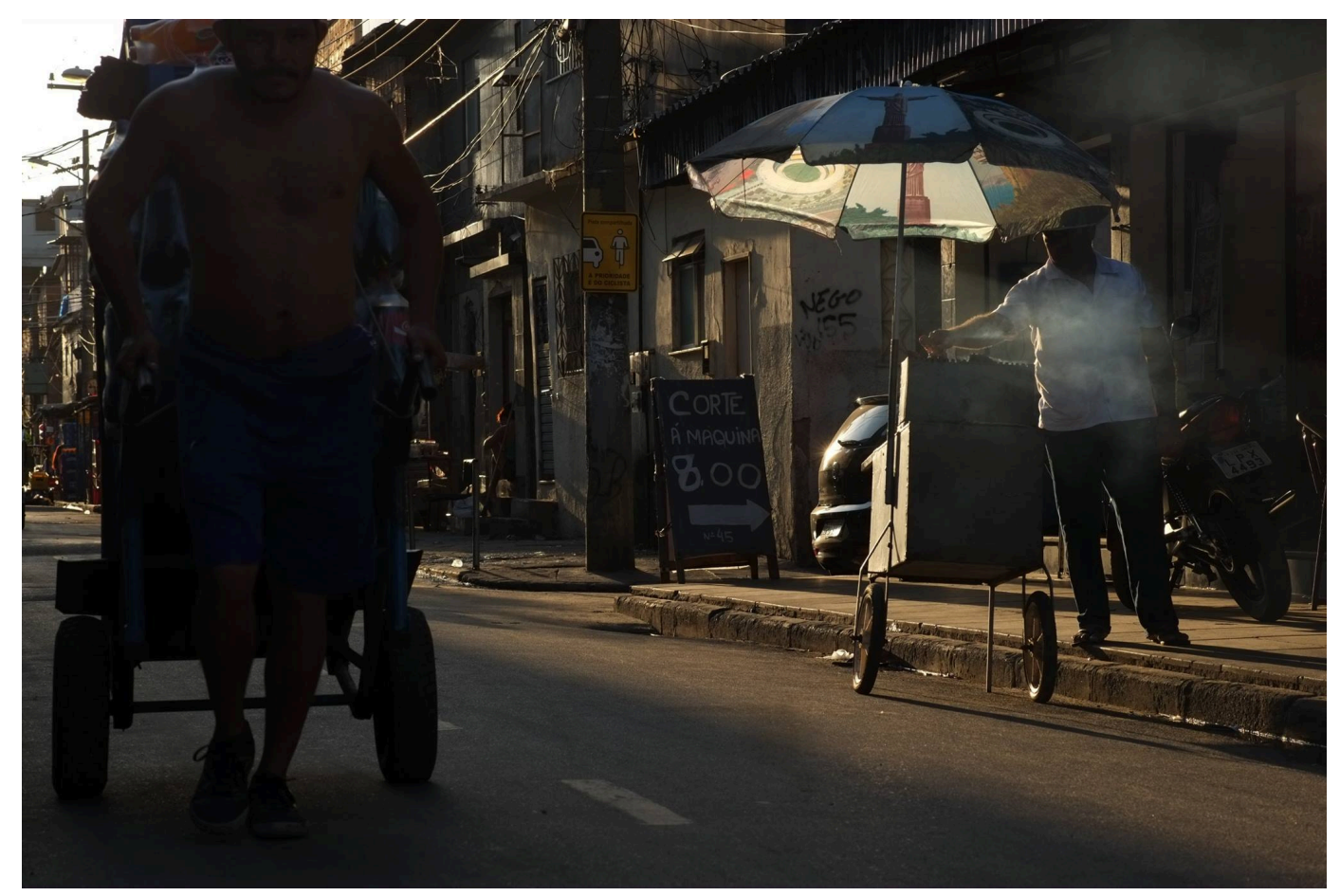

Figura 30 - Fotógrafo: Bira Carvalho

A placa de chão, no centro da imagem, nos aponta para outra natureza/categoria de transformação do espaço. Para além de transformações de caráter temporário, como as apontadas até aqui, o espaço físico em si também passaria constantemente por mudanças estruturais. Sob o texto "Corte à maquina 8,00", uma seta aponta para a entrada de uma pequena rua, onde um barbeiro instalou seu estabelecimento comercial no primeiro piso de uma casa.

A unidade residencial, fato vastamente conhecido, muitas vezes se torna também local de trabalho ou ponto comercial ${ }^{121}$. É curioso notar como esta característica de ocupação/adaptação das residências é frequentemente feita pelos moradores de favelas do Rio de Janeiro, mas ignorada quando são desenvolvidos diferentes projetos de conjuntos habitacionais. Vale pontuar rapidamente a fala de um morador, Lourenço Silva, também diretor do Museu da Maré, sobre o premiado projeto do conjunto habitacional Nova Maré ${ }^{122}$. Segundo Lourenço, a área sempre foi o local com menor poder aquisitivo dentro do complexo e continuou sendo após

121 Mais uma vez, voltamos à questão de Alexander (1965) e Mello e Vogel (1985).

122 Comentário feito durante uma mesa de discussão no Seminário UrbFavelas, realizado em novembro de 2016. 
o investimento urbano: esse fato, segundo sua observação, se dá porque o projeto das casas não contemplou a possibilidade de modificação das unidades habitacionais para possíveis usos comerciais.

A utilização da casa como espaço para gerar fonte de renda é uma realidade não apenas conhecida, mas necessária para a dinâmica e circulação de recursos financeiros locais. Tais intervenções funcionam também como forma de se constituir um uso misto do espaço, gerando assim serviços próximos às unidades residenciais, as quais supririam necessidades dos moradores.

Jane Jacobs, na década de 1960, já apontava para a importância da mistura de atividades em áreas urbanas. E na Nova Holanda (assim como em diferentes favelas cariocas) esta mistura se daria também através de intervenções em unidades residenciais. Em Morte e Vida de Grandes Cidades (2000), a autora critica planejadores urbanos que, ao invés de entenderem a importância de conhecer o funcionamento das cidades no cotidiano nas ruas das cidades existentes, esforçavam-se a aprender com os pensadores do urbanismo moderno ortodoxos seus dogmas sobre como a cidade deveria funcionar e o que seria bom para seus moradores e para os negócios. E, em tal pensamento, o pressuposto da separação para a obtenção da ordem e do bom funcionamento urbano - iria ditar as propostas de localização de atividades. Assim como a "denúncia" de Jacobs de que tal fragmentação não condiz com a realidade urbana das ruas, os usos e intervenções feitos na Maré revelam como tal mistura é intrínseca do espaço e como se adequa à realidade vivida cotidianamente pelos moradores no local. Como aponta Bira Carvalho ao falar sobre as transformações físicas nas residências para fins comerciais:

Geralmente o comércio começa no primeiro andar, que acaba virando ponto comercial. E a freguesia vai até ele. Mas como aqui tem muita coisa [muita concorrência], ele tem que ficar se renovando. Porque muitas vezes o outro já coloca outra coisa nova. E aí muitas vezes ele migra para uma dessas ruas principais: Teixeira, rua Principal.

Além de falar sobre o uso das residências e da dinâmica de transformação na instalação de áreas comerciais, Bira fala também sobre a transformação espacial constante em virtude de questões econômicas: 
Aqui [na rua Bitencourt Sampaio, onde ocorreu a entrevista] era muito mais residencial, aqui fora do Bela [Maré]. Mas está se transformando: aqui [na Nova Holanda] tem o comércio da Teixeira [rua Teixeira Ribeiro], mas que não está mais dando conta dos moradores. Então o comércio vai migrando... o tal lugar era caro, então coloca outro ali; o baile que era só na Teixeira, agora é também aqui... então naturalmente as coisas do primeiro andar [na Bitencourt Sampaio] vão virando comércio. Com a crise, tem muito mais ambulante. $\mathrm{O}$ pai que foi mandado embora, ou a menina, botou uma barraca. E aí a barraca da noite já muda. À noite é muito a barraca de alimento. Porque o cara que tem poderes aquisitivos, o traficante, ele sai do meio da tarde para noite. E aí fica com preguiça de ir para casa de comer e come ali mesmo.

O registro de usos de lajes de residências também ilustra o contexto apresentado aqui, tanto através do uso para o lazer e o lúdico - a partir de diferentes interações que promove - como também por demonstrar-se como alternativa criada para responder ao caráter dinâmico do espaço em um contexto contemporâneo (SolàMolares, 2002). Além de funcionarem como novos quintais das casas, como aponta Elisângela Leite, a estrutura construtiva permite também que o local se transforme em futuros cômodos para novos membros da família ou como fonte de renda alternativa através do aluguel do espaço. AF Rodrigues ${ }^{123}$, fotógrafo também formado pelo Imagens do Povo e morador da Nova Holanda, possui um interessante ensaio sobre o uso das lajes. Apesar de não tê-lo entrevistado, cabe aqui reproduzir um texto disponível em seu Flickr sobre um projeto fotográfico sobre lajes:

Desde sua formação, a Maré sofreu um crescimento muito grande. Com este crescimento, o que antes era um quintal com uma ou mais árvores, foi sendo substituído, aos poucos, por novos cômodos a fim de abrigar os novos entes que iam nascendo. Esta ocupação, que se conformou, ao passar dos tempos, como forma de resistência à ausência do Estado em constituir projetos de construção de casas populares, contribuiu para a diminuição das áreas dos quintais e varandas onde ocorriam as brincadeiras e festejos das famílias. No entanto, em um processo de readaptação essas atividades foram sendo aos poucos, transferidas e realizadas em um novo espaço que surgia com o advento das construções de alvenaria, as lajes. Neste sentido, as lajes passaram a ter status de quintal, de varanda da casa. Espaço onde as famílias se reúnem para dar um churrasco para amigos, onde se toma banho de sol e se refresca com mergulhos na piscininha de plástico e / ou se molham de mangueirinha e, que as crianças sobem para soltar pipa e brincar de pique. A laje hoje, é mais que uma possibilidade de um novo cômodo, é o espaço que garante ao trabalhador o direito ao lazer, direito este negado por um Estado omisso. Maré, Rio de Janeiro, Brasil, América do Sul.124

123 Seu trabalho está divulgado em: https://www.flickr.com/photos/af_rodrigues/albums/with/72157602790062776 124 Fonte: https://www.flickr.com/photos/af_rodrigues/sets/72157602790062776 
A Figura 31, de Elisângela, ao mostrar o horizonte da Nova Holanda em um fim de tarde, reproduz alguns usos feitos nos espaços das lajes.

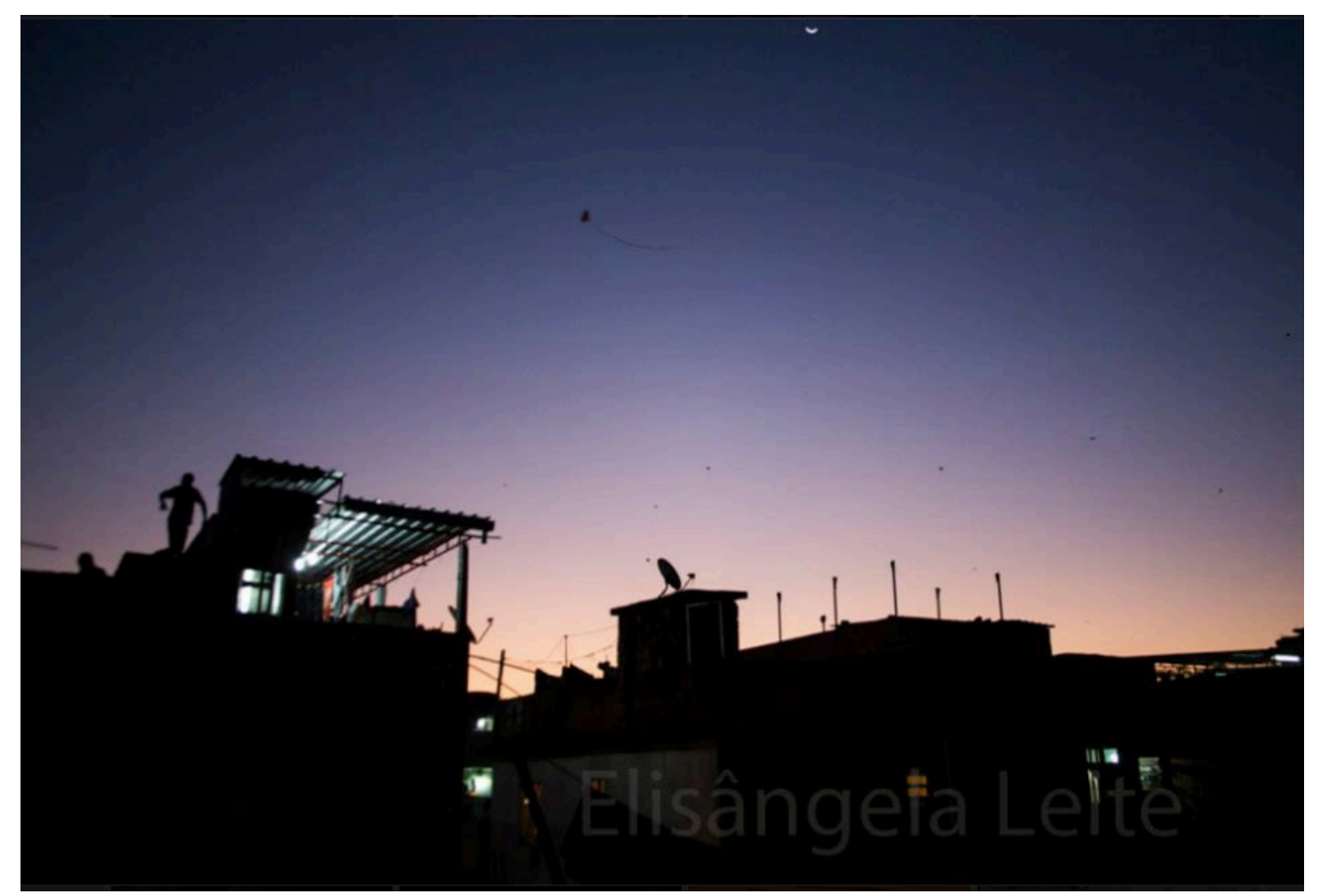

Figura 31 - Fotógrafa: Elisângela Leite

Essa foto tirei da minha janela. Estava um sol bonito, final de tarde... aí queria mostrar um pouco dessa cultura de soltar pipa, da cultura da laje, do lazer que falta na favela. que as pessoas usam mesmo. tinha muita pipa passando e a lua aparecendo lá no cantinho. E aí mostrar na contraluz as lajes, com suas antenas de tv, outras com as caixas d'água... mostrar essa vida, né?

Para além da pluralidade de usos, o tema do "empinar pipa" se destaca na imagem. Vemos uma delas mais nítida à frente e pelo menos outros seis "pontos" ao fundo. O perfil de um menino no topo de uma das casas também nos faz supor que esteja ali pela brincadeira. Além do vasto uso de jogos digitais e da internet, a afeição por pipas ainda é comum entre jovens da Nova Holanda. A brincadeira, reproduzida há diversas gerações, é representativa de algumas questões que colocamos aqui. Em primeiro lugar, ela fala sobre o intervir no espaço comum através do lúdico. Apesar de estar sendo feita a partir de um local privado - a laje de uma casa -, o desenho feito no ar traz, como menciona Elisangela, vida àquele espaço, ele enfeita o céu da Nova Holanda. Os movimentos possibilitados pelo vento e pelo puxar da linha supõem também interação/compartilhar, não só com quem também solta pipas em outras lajes ao redor, mas também com aqueles que veem do chão o "baile" das pipas no céu e, assim, retornam à infância. 
O lúdico e as trocas, mais uma vez, se mostram presentes no espaço, agindo sobre ele e o transformando; revelam-se desta forma como características cruciais pretendidas para compor o espaço habitado.

\subsection{4}

\section{Espaço de fé e resistência}

O caráter de transformação do espaço é ainda citado por Bira ao falar sobre um quarto elemento que se destacou como representativo sobre a Nova Holanda: a questão da fé e da resistência às violações de direitos, vividos constantemente na favela e em toda a Maré. Ao relatar uma história contada por sua mãe, diz:

Minha mãe veio para cá na década de setenta, e logo depois estoura uma guerra do tráfico. E ela vinha da roça, então ela decide que não queria mais ficar ali. Então ela comenta isso com uma senhora, e ela diz: "para de bobeira, minha filha. Aqui, tudo é passageiro."

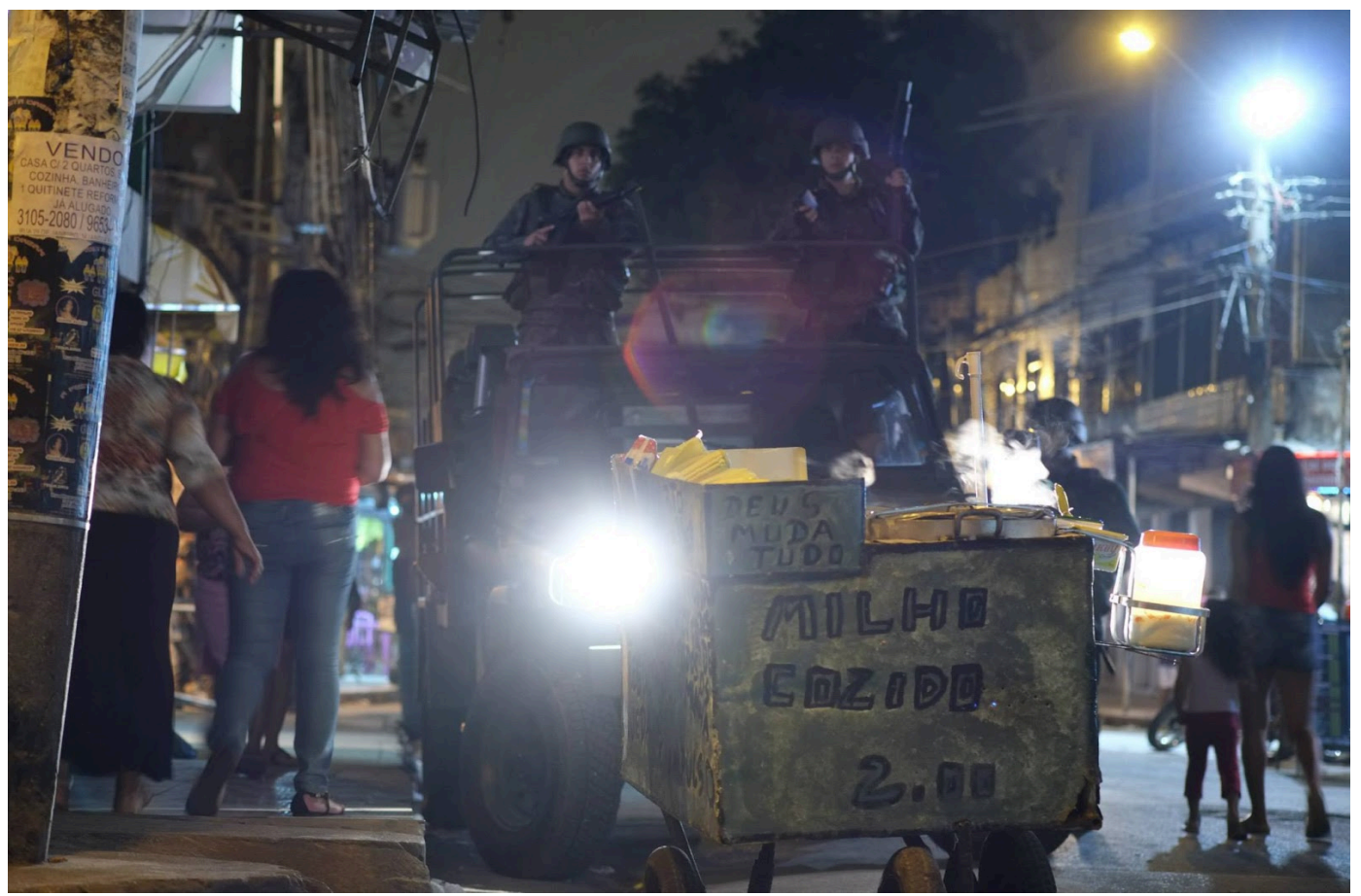

Figura 32 - Fotógrafo: Bira Carvalho

Bira relata o caso ao falar da Figura 32, registro feito durante a ocupação militar realizada na Maré em 2014. Na ocasião, 2.500 militares do exército substituíram a polícia militar no local, a qual estava presente na região em virtude da política de segurança pública do Governo do Estado, mais conhecida como plano de "pacificação" da cidade - mencionada no capítulo 3. Na época, Bira conta que 
haviam rumores sobre a implantação de uma Unidade de Polícia Pacificadora (UPP) no Complexo, fato que até a data atual não se concretizou. A ocupação ocorreu alguns meses antes do início da Copa do Mundo de 2014 e se estendeu por 15 meses.

A Figura 32 registra uma das principais ruas da Nova Holanda, já à noite, em um horário de grande movimento. $\mathrm{O}$ fotógrafo mira o carro do exército de frente. As pedestres, todas mulheres, aparecem de costas, caminhando no sentindo oposto do veículo militar. Bira vê a cena da mesma direção que elas. No centro da imagem, parado na rua e à frente do veículo militar há um carrinho de milho cozido no qual o dono não aparece na imagem. Escrito à mão na superfície do material metálico, a frase "Deus muda tudo". Apesar de a imagem ser nítida, vemos alguns detalhes que, pelo "borrar", criam a ideia de movimento - efeito criado através da baixa velocidade do obturador da câmera. Para além do corpo das mulheres e da fumaça da panela do milho - elementos que podem ser entendidos como representativos dos moradores e sobre a vida da Nova Holanda -, todos os outros elementos da cena estão "congelados" (estáticos). Ao falar sobre a imagem, Bira diz:

\begin{abstract}
No meio dessa tensão, que a gente não sabia o que era UPP, essas palavras [ditas pela senhora para sua mãe] estavam guardadas em algum lugar aqui dentro e eu começo a fazer muita foto de baixa velocidade. Porque eu percebo que essa ação do exército vai passar, mas ainda não passou. E quantos outros moradores perpassaram por aqui e não estão mais na favela, quantos amigos... representa tanta coisa. Essa vulnerabilidade de que as pessoas foram passando por esse espaço. E aí as vezes, hoje, a marca vai se definhando. E aí, por isso que esses primeiros [registros sobre a ocupação militar] eu fiz em baixa velocidade, principalmente as primeiras fotos da ocupação à noite. Até porque eu estava buscando ainda... os caras invadiram a minha casa, quebraram todo meu material fotográfico e a minha casa. Então eu não podia usar a fotografia...
\end{abstract}

Bira parece transmitir duas questões através do termo "passageiro". A primeira, de certa maneira, uma visão de caráter positivo, de que há sempre uma esperança de que situações críticas não irão perdurar para sempre. A segunda, por outro lado, de que esta "vulnerabilidade" - uma "instabilidade" - é também responsável pela alta rotatividade de moradores na Nova Holanda e na Maré, transformações constantes que seriam responsáveis também pelo definhamento de memórias locais.

Ao falar sobre o que a imagem representava sobre a Maré, o fotógrafo aborda a questão sobre resistência. A velocidade do obturador escolhida para tirar a foto pretendia mostrar, enquanto processo, como aquela intervenção militar seria 
passageira, como aquela situação não ficaria para sempre. As pessoas da imagem demonstrariam, segundo Bira, a resistência da vida que segue, apesar de tudo, de uma insistência que teima em querer continuar caminhando apesar dos grandes bloqueios que se vêem no caminho. O carrinho de milho cozido, também símbolo desta insistência dos "pequenos", parece que, através de sua fé exposta pela placa com os dizeres "Deus muda tudo", pode contrapor os atropelos impostos.

Imagina como essas relações [da ocupação militar] afetam a isso [ao vendedor de milho cozido]: em qualquer lugar isso afeta as vendas. Quebra. Eles não quebram a boca, eles quebram o pequeno comerciante. E como ele resiste? Então para mim, era muito sobre isso.

As palavras "luta", "fé", "resistência" foram citadas em diferentes momentos durante as entrevistas. Tais questões teriam interferência direta em certos momentos sobre a forma de usar e de "fazer" o espaço. A questão referente a "resistência", fala sobre a postura dos moradores em relação à construção do cotidiano em resposta às ausências de direitos ou da simples tentativa de "manter" uma rotina normal, tal qual a descrição feita acima por Bira, ou a fala de Elisângela sobre as piscinas montadas na porta de casa.

A questão da fé, por outro lado, estaria ligada a aspectos religiosos ou à demonstração de esperança de mudança em espaços comuns. Neste sentido, além da imagem da tenda da Igreja Vernáculo de Fogo (figura 17) e da distribuição de doces em São Cosme e São Damião (Figura 22), outra imagem de Bira fala também sobre a fé representada na rua.

O fotógrafo desenvolve um trabalho que chama de "Arte Sacra em Favela". Nele, registra paredes de diferentes ruas onde motivos religiosos - em sua maioria evangélicos - são grafitados. Bira conta que começou os registros em 2008, quando passou a perceber não só o surgimento dos desenhos nas casas, mas consequentemente - como a favela teria um forte cunho religioso que era marcado no espaço.

Em seus percursos pelas ruas da Nova Holanda (assim como em outras favelas da Maré, segundo Bira), grafites presentes em muros e paredes de casas reproduziam salmos da Bíblia e imagens de Jesus, ou de santos, como São Jorge. Segundo Bira, muitas das pinturas seriam encomendadas pelos traficantes que, ao fazê-las em 
locais por onde passavam, buscariam proteção. Vemos uma imagem do trabalho em questão na Figura 33.

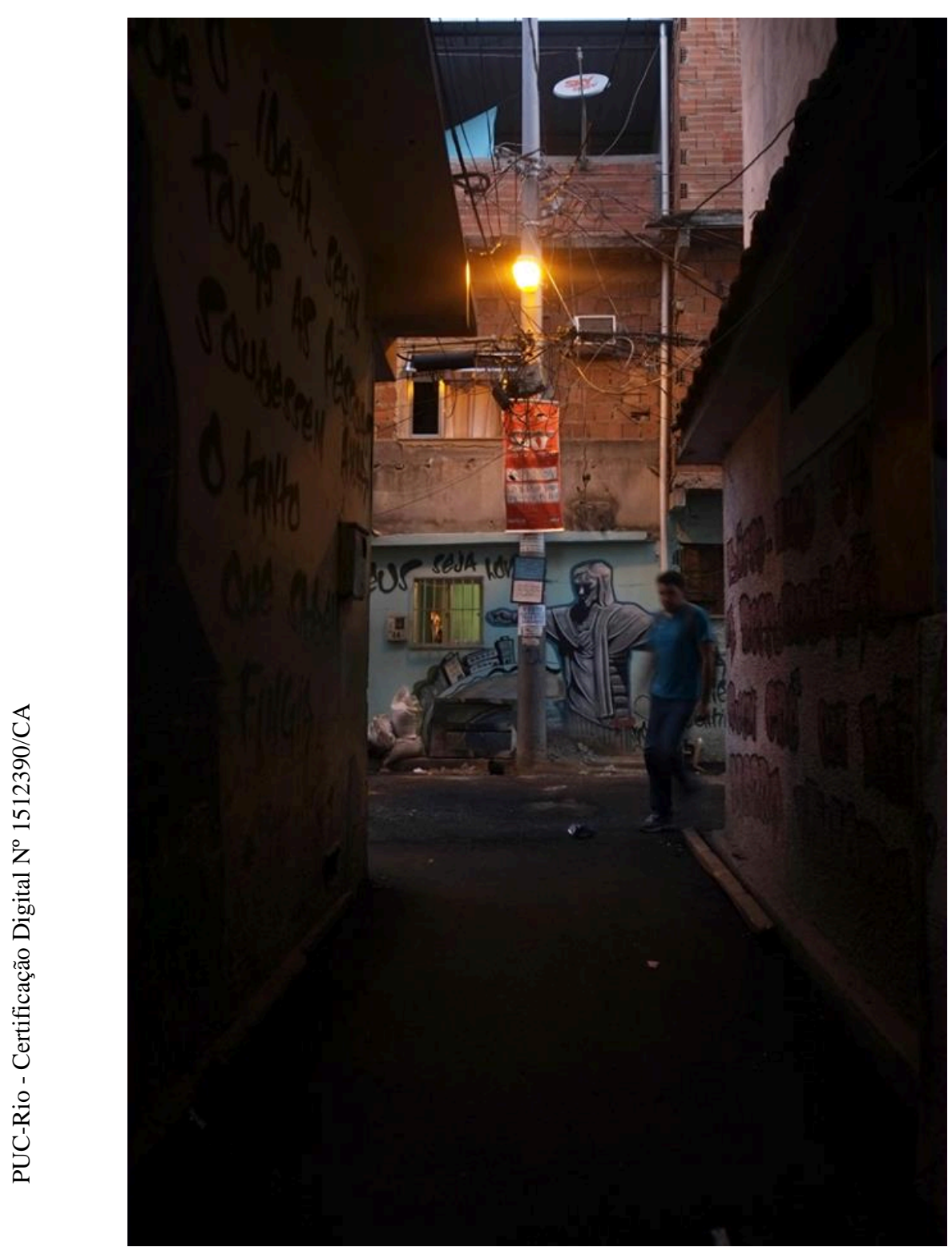

Figura 33 - Fotógrafo: Bira Carvalho

A fotografia (Figura 33) é tirada de uma ruela. O enquadramento faz da imagem densa, inteiramente composta por elementos construtivos. Toda a sua área é ocupada por paredes de alvenaria ou pelo asfalto da rua - além de um homem que aparece virando a esquina. $\mathrm{O}$ espaço estreito de onde Bira fotografa, cria um ambiente escuro. Os limites das paredes da ruela emolduram a parte iluminada da rua à frente. Justamente no centro da imagem, um grafite do Cristo Redentor com a frase "Deus seja louvado" na parede de uma casa. A penumbra criada pela luz do poste nas paredes da ruela aponta também para a existência de grafites ali, os quais seriam frases, mas que não sabemos ao certo sobre o que falam. 
Ao discorrer sobre um outro registro feito para a série "Arte Sacra em Favela"125, Bira relata um determinado acontecimento e aponta para a questão da interferência da fé nos usos dos espaços. O grafite teria sido feito em uma parede inteira de uma casa de dois andares com a imagem de Jesus sendo batizado. Antes da intervenção, o local estava sendo utilizado para o consumo de crack. Ao iluminarem e pintarem a imagem bíblica, segundo Bira, o uso do espaço foi transformado drasticamente e os usuários passaram a não o frequentar.

Seja em confraternizações, através de frases em instrumentos de trabalho (tal como o carrinho de milho) e paredes ou em outros gestos cotidianos, a fé, segundo Bira, faria parte da história e da forma como a favela seria formada:

A fé é muito presente na Nova Holanda e nas favelas. Se você pegar os imigrantes do Nordeste, quando o cara não tem nada, ele só tem a fé. A fé tem que ser mais forte. A fé aqui está muito presente... e sempre esteve. Os malandros que usavam guia, os padres que tinham aqui...

A observação de Bira sobre as pinturas religiosas nas paredes e os outros usos e ações que demonstram a presença do culto da fé no espaço remete a Joseph Rykwert, em "A ideia de cidade" (2006). Em seu livro, Rykwert defende que a construção da cidade, além dos espaços psicológico e cultural, deveria considerar também o espaço religioso. $\mathrm{O}$ autor analisa cidades da antiguidade para mostrar como o ser humano recorria aos rituais e mitos para formar seu ambiente urbano, criticando, assim, a maneira como os urbanistas da atualidade passam a considerar a cidade em uma perspectiva unicamente funcionalista, como "uma complexa peça de maquinário" (RYKWERT, 2006, p. XLVIII). Ao falar sobre as cidades romanas, entre outras, mostra como o caráter simbólico presente através de ritos a deuses na construção de elementos defensivos como fossos ou muralhas - ou mesmo na construção de templos e monumentos -, era de fundamental importância para a vida e construção urbana. Como aponta Diniz Moreira na introdução do livro, segundo Rykwert, "a estrutura urbana estava em harmonia com as forças que regem os cosmos. (...) O que Rykwert sugere é que as pessoas só se sentem parte de uma

125 Outros grafites do projeto de Bira podem ser vistos em sua pasta de imagens do Facebook chamada "fé": https://www.facebook.com/bira.carvalho.73/media_set?set=a.626354067462297.10000263128415 $0 \&$ type $=3$ 
comunidade se há uma correspondência entre seu cosmo e o mundo construído que as rodeia" (Diniz Moreira in Rykwert, 2006, p.XXXIV).

As pinturas presentes nas paredes da Nova Holanda nos remetem ao pensamento do autor. É verdade que a definição do desenho urbano local não foi desenvolvido a partir de ritos religiosos, mas os grafites presentes em diferentes locais parecem, segundo relato de Bira, carregar um caráter simbólico para seus moradores, funcionando, de certa maneira, como elementos defensivos dentro das disputas locais. A definição das áreas de execução das artes poderiam acabar traçando e (re)afirmando rotas protegidas por uma determinada dimensão espiritual, e quem sabe, definindo trajetos de locomoção.

Imagens de Rosilene Miliotti também falam sobre a fé materializada no espaço comum através de grafites: a Figura 34 compõe o grupo. A imagem faz parte de um ensaio sobre uma procissão religiosa da Igreja Católica, a qual vemos no canto direito da imagem. À esquerda, grafitado em um muro, uma frase, que seria um verso do grupo de rap Racionais MCs, segundo o crédito apontado ao final. Ao falar sobre o grafite, Rosilene diz:

Foram dois anos onde [a procissão] cruzou desde o Parque união até Pinheiro, por dentro. E aí eu comecei a perceber as mensagens, os grafites, coisas que eu não percebia. E hoje está até no meu Instagram: as vezes eu fotografo uma mensagem que está na rua, posto e coloco \#MensagensMarginais. Tem um amigo meu que usa e eu acho muito legal, né... são as mensagens que estão na rua o tempo inteiro e a gente não vê. 


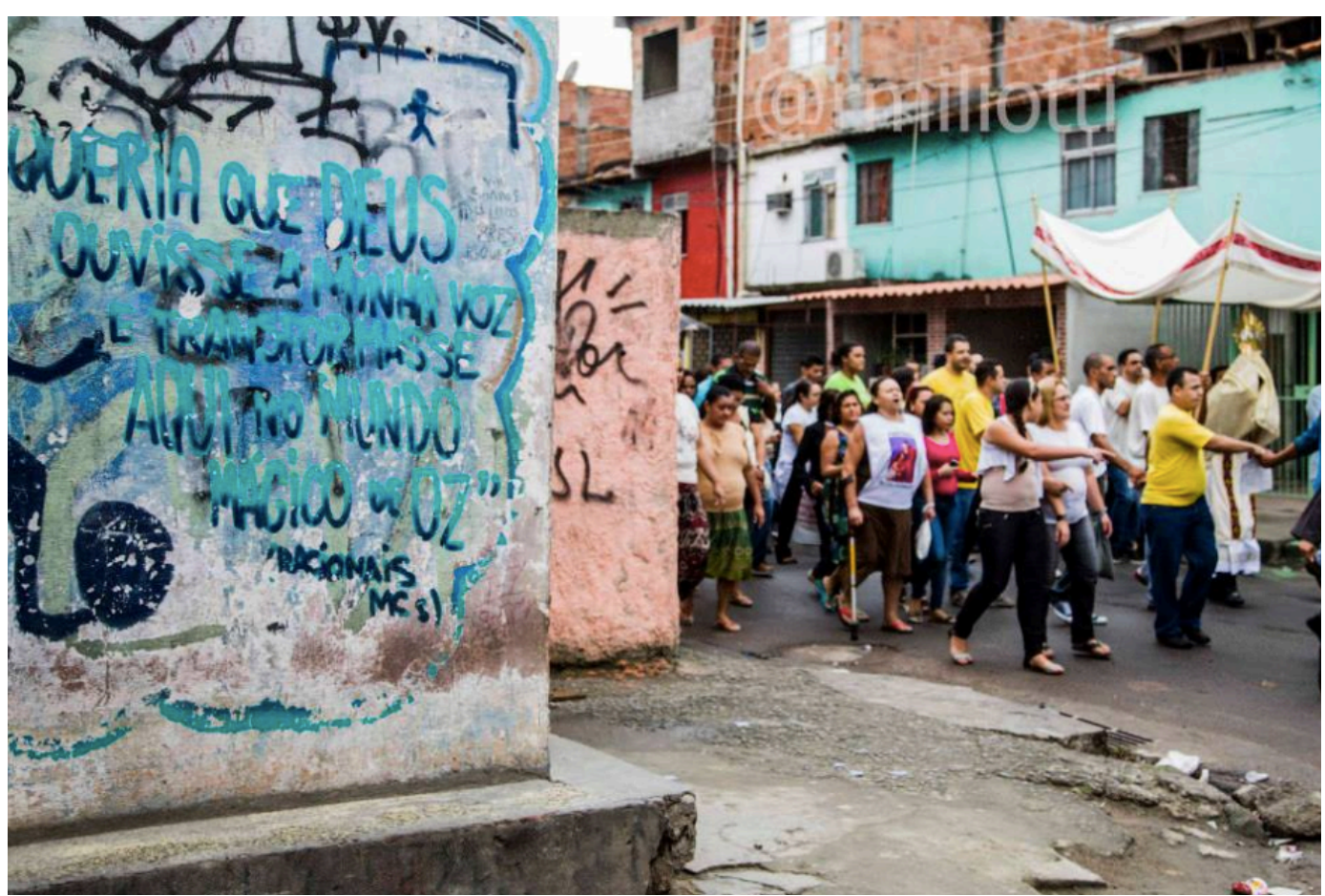

Figura 34 - Fotógrafa: Rosilene Miliotti

O foco da fotografia em questão está direcionado para o grafite exposto no primeiro plano. Seu conteúdo destaca um trecho de uma música dos Racionais MCs: "Queria que Deus ouvisse a minha voz e transformasse aqui no mundo Mágico de OZ". A música faz referência ao filme clássico do cinema no qual a menina Dorothy sonha estar em um lugar melhor do que a sua casa. A letra dos Racionais MCs conta a história de um menino negro de 12 anos de idade que tenta sobreviver em uma realidade de violência e falta de oportunidade em uma grande capital. Ao mesmo tempo em que critica as desigualdades sociais e o descaso com situações similares à vivida pela criança, o compositor mostra também fé em um Deus que poderá mudar o rumo da realidade. A música descreve o cotidiano de metrópoles brasileiras, fala sobre fé e sobre o desejo por um mundo diferente - mundo este, próximo à fantasia.

Através de ações tão distintas - como o grafite com letra de Rap e a procissão católica do Corpus Christi -, a fotografia registraria como os moradores utilizam o espaço comum para demonstrar sua fé e a crença em forças divinas. A partir da imagem vemos, mais uma vez, não só a pluralidade existente no espaço, mas também a importância do tema da fé na Nova Holanda. Como diz Rosilene, 
Eu não vou estar lá enfiada na igreja, mas eu quero o bem das pessoas. E eu quero perceber isso aqui [na rua]. E a gente percebe isso na parede, nos lugares... É mostrar um pouco isso. Quero registrar a fé das pessoas.

A motivação principal para o ensaio, por outro lado, não teria sido apenas o registro da procissão católica. Segundo Rosilene, seu objetivo seria fotografar a presença do exército (o qual, geralmente, não se deixaria fotografar), assim como entender de que forma se daria o evento religioso em meio à vigilância dos militares.

$\mathrm{Eu}$ comecei a querer fotografar as procissões por causa do exército. Eu queria fotografar o exército, mas eu tinha medo. E realmente, eu fotografei "a procissão". Tenho várias [ensaios sobre procissão]: domingo de ramos, corpus christi... mas quando eu estava na procissão, eu estava preocupada com o exército, né... sobre qual era a relação da igreja com os soldados... você está passando na procissão e tem um soldado armado ali, sabe? A gente não via o tráfico na beira... às vezes passava por uma boca de fumo, eles estavam ali para dentro, mas o exército era o caminho inteiro: sempre tinha alguém de verdinho, parado, armado. E nessa procissão teve um ponto onde os comandantes encontraram e cada um pegou um desses negócios aqui [a haste da estrutura da "tenda"] e foram levando, e tinha um pessoal do exército... essa coisa foi esquisita, sabe? Para algumas pessoas causou um incômodo. (...) e aí eu comecei a "usar", muito entre aspas, dessas festividades católicas, para fotografar esse entorno da Maré, a questão do exército, a questão da polícia, e se causava estranheza ou não...

O registro do período da ocupação do exército é comum não só aos três fotógrafos entrevistados, mas a diversos outros que também moram na Maré. Tanto Elisângela, quanto Bira e Rosilene, ao trazerem o olhar do morador sobre o assunto - uma situação que, recorrentemente, constrói estigmas sobre o complexo de favelas -, colocam como tema de muitas das imagens a postura do habitante em meio à ocupação. Em comum, todos irão falar sobre como, frente ao "cenário" de guerra montado em suas portas e às diversas violações de direitos denunciados ${ }^{126}$, os moradores seguiriam seus afazeres e seu cotidiano - obviamente, dentro do possível. Tal como apontado a partir da fala de Bira Carvalho anteriormente, também para Rosilene Miliotti e Elisângela Leite, a postura dos moradores se mostraria como uma forma de resistência. Segundo relato de Bira:

Mesmo num estado de violência, as pessoas resistem. Resistem, circulam... até a forma de ser alegre em favela é uma forma de resistência... você vê a própria criação do samba. E a favela vai resistindo, vai saindo... o povo aqui é muito "rueiro". Os caras falam que aqui é uma das favelas mais "rueiras" que tem no Rio.

126 Segundo a ONG Redes da Maré. 
A rua, importante pontuar, aparece em diferentes relatos entremeada à discussão sobre a violência e a resistência. Na fala de Bira, exposta acima, ser "rueira" faz da Nova Holanda uma favela que mostra que não se retrai frente às imposições estabelecidas pelos conflitos. Elisângela, ao falar sobre a Figura 35, também aborda a questão:

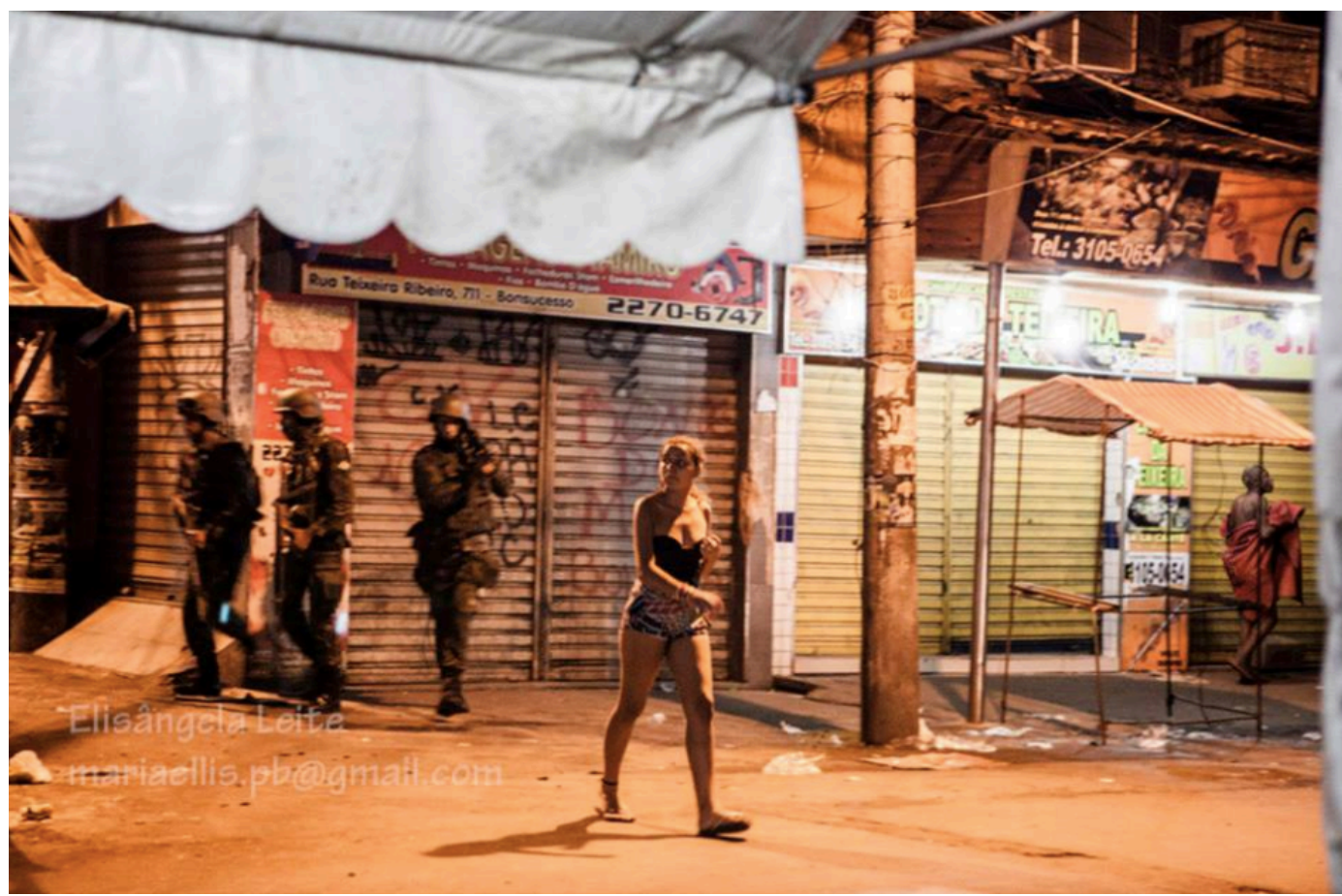

Figura 35 - Fotógrafa: Elisângela Leite

$\mathrm{O}$ exército, quando estava aqui, tinha muito confronto. Por causa dessa coisa do espaço de lazer, e de eles quererem passar e não ter espaço. E pela população falar "eu estou na minha casa, na minha porta". E ter aquele impasse. Devia ter uma conversa, mas eles já partem para um confronto.

Para mim [durante a ocupação militar] só muda que tu está aqui nessa esquina e tem alguém revistando. Chega na outra esquina, também tem outro revistando... e aí tem abuso de autoridade. Isso que muda. Porque a favela continua viva do mesmo jeito, as pessoas continuam fazendo seus afazeres do mesmo jeito: sentando nos bares, bebendo, escutando música alta, conversando...

O "apropriar-se" do espaço mais uma vez aparece nos relatos, mostrando-se aqui, claramente, como resistência à violência e reivindicação ao direito à cidade. Ser "rueiro", ter o espaço comum como quintal e ter a natureza implícita do negociar o espaço se mostra como uma maneira na Nova Holanda de demonstrar que os moradores têm voz sobre o espaço, que os habitantes são parte dali, e que, assim, devem participar das decisões do que se pretende para ela, tal qual vimos ser construído através da história local no início do capítulo. Rosilene relata uma situação que ilustra esta característica local: 
Uma coisa que causou um "zumzumzum" foi a pintura das ruas para a tal da ciclovia. As pessoas olhavam para aquilo e riam. Porque achavam um absurdo o valor que foi gasto, ne? E aí vinha um cara pintando, dias depois aquela tinta já não estava mais ali, ela apagava. E você falava com as pessoas e as pessoas riam. Falavam "não sei porque eles estão gastando dinheiro com isso aí, porque isso não vai dar certo". Porque as pessoas não querem saber da organização daquele jeito.

O projeto da ciclovia da Maré fazia parte do programa da prefeitura "Rio Capital da Bicicleta" ${ }^{\prime 127}$. Ao continuar o relato sobre a ocasião, Rosilene aborda a reação das pessoas ao projeto:

"Como assim isso vem para cá desse jeito? Quem é que vai dizer que a ciclovia tem que ser assim? Como vai ter ciclovia se aqui tem um monte de carro? E como vai ter ciclovia do outro lado se tem a banquinha, a loja, a sinuca que o cara tira de dentro do bar e coloca na rua?". As pessoas riam. E essas criticas até eram generalizadas na Maré, mas na Nova Holanda, eu percebia um tom mais crítico e sarcástico, muito mais do que nas outras.

O tom crítico, segundo Rosilene, seria forte na Nova Holanda não só pelo custo do projeto e da má qualidade da execução, mas também pelo fato de não terem sido feitas consultas aos moradores da favela. A rua Teixeira Ribeiro, a qual Rosilene se refere, já teria sua própria lógica de funcionamento. O desenvolvimento de projetos para o espaço comum demandaria a consulta daqueles responsáveis por construir o espaço e por habitá-lo cotidianamente:

Nas outras [favelas da Maré] muita gente não ligava, não estava nem aí. Mas na Nova Holanda, as pessoas riam daquilo, daquela situação. A Nova Holanda é aquilo ali. E se mudar, não vai ser a Nova Holanda. O espaço é do morador, das pessoas que fazem ele. Porque você não tem o Estado ali, né? Quando o Estado entra é pela força policial, que entra, faz o que faz e sai. Você não consegue ter uma organização. Então, são os próprios moradores que se organizam. E a forma que eles acharam para se organizar, é essa. E é essa desde que foi criada. Elas foram jogadas ali, não tinham água, não tinham nada. $\mathrm{E}$ as pessoas se viraram para ter as coisas. E como é que você chega agora e você quer organizar isso aqui se eu, desde que isso aqui foi criado, eu me organizei desse jeito? Não dá para ser uma coisa de cima pra baixo assim... não vai, não adianta... e é isso. A Nova Holanda é isso aí.

A figura 36, de Bira Carvalho, retrata a rua do relato de Rosilene, a Teixeira Ribeiro. $\mathrm{Na}$ imagem, vemos a dinâmica do espaço em um horário de grande fluxo, já ao

127 O projeto visava ampliar o sistema cicloviário da cidade, tornando o Rio de Janeiro a maior rede de ciclovias da América Latina. O projeto da Maré teria o custo inicial de R\$ 7 milhões e previa a implantação de vinte e dois quilômetros de ciclovia com faixa compartilhada e integraria as favelas do complexo com as estações do BRT. A ciclovia na Nova Holanda passaria ao longo de suas duas principais ruas: a rua Teixeira Ribeiro e a rua Principal, vias de intenso movimento. 
anoitecer. A iluminação de lojas e da rua clareiam a imagem. Pessoas circulam em diferentes direções e através de distintos meios, seja a pé, de bicicleta ou moto. A imagem reproduz um espaço pulsante, vivo.

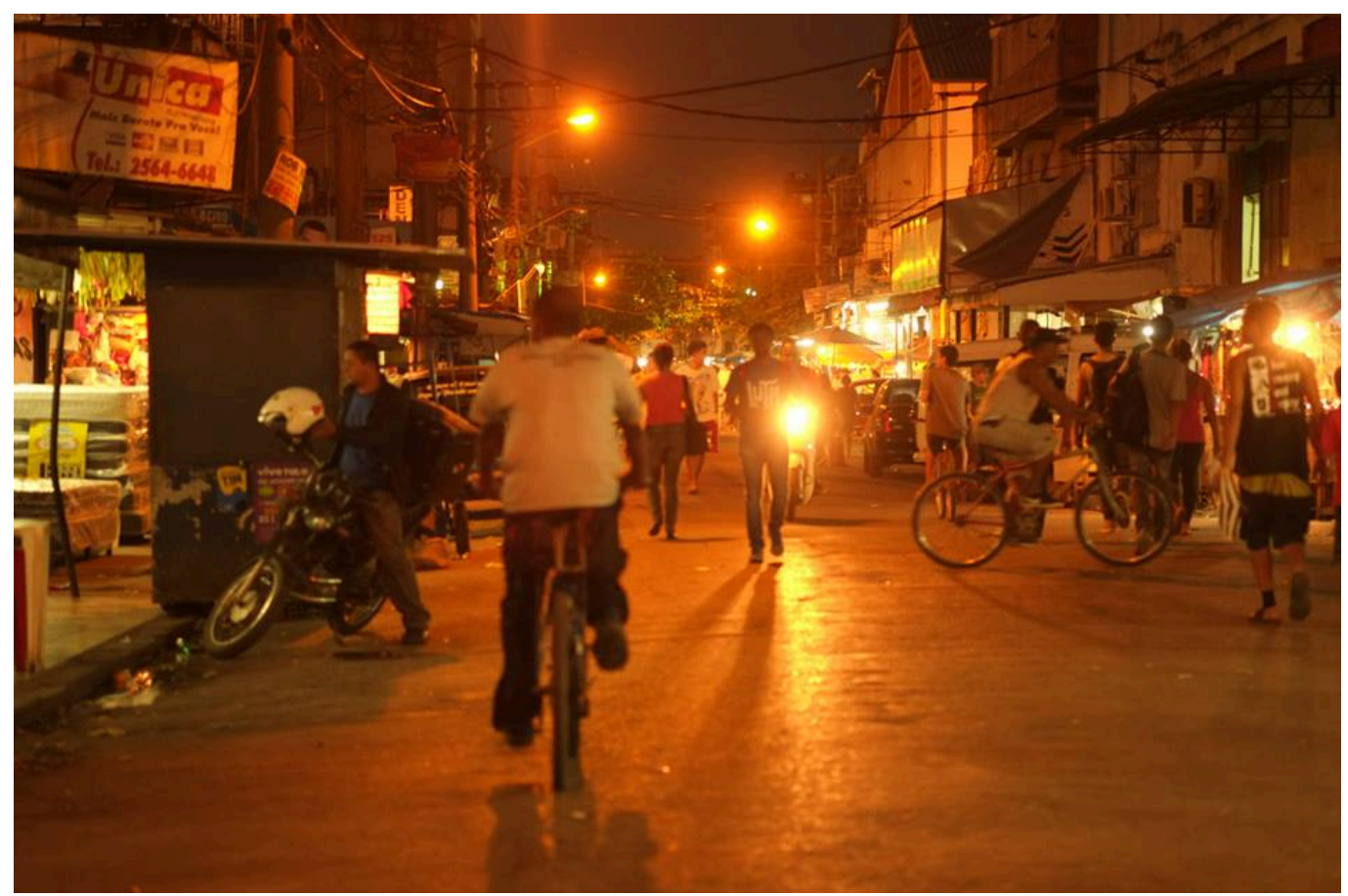

Figura 36 - Fotógrafo: Bira Carvalho

Ao falar sobre o registro, Bira aponta não apenas para a questão dos moradores como construtores da Nova Holanda, tal como a fala de Rosilene, mas os projeta para o contexto de luta e resistência no Rio de Janeiro como um todo. O fotógrafo, ao ser perguntado sobre a representação que buscava construir, aponta diretamente para o jovem no centro da imagem, que caminha na direção da câmera:

Você reparou? O que está escrito na camisa desse rapaz aqui [no centro da imagem]? ["luta"?] É. É o momento que os guerreiros estão indo ou vindo da luta. Ele está indo para faculdade e o pessoal está vindo do trabalho. E começa uma terceira luta, do pessoal de casa, principalmente a mulher: uma outra jornada. $\mathrm{Me}$ remete que eles que construíram essa cidade que eu amo. Porque parece que é um lugar separado, mas não é separado. A questão da periferia no Rio é muito mais associada do que espacial. E eles que construíram essa cidade. Então quando eles saem, eu fico encantado. Quando eles chegam, eu fico olhando, meio que namorando: "lá vão eles". 


\section{5 \\ Considerações finais}

Pode-se dizer que, se ao longo do período de 2009 a 2016 buscou-se fortalecer a imagem do Rio de Janeiro como uma cidade própria para ser palco de megaeventos através de diferentes meios, representações construídas pelos habitantes sobre seus espaços propuseram questionar o que se estaria reproduzindo e omitindo sobre a realidade da cidade. Através da pesquisa, explorei diferentes olhares produzidos sobre o espaço urbano carioca neste período para, assim, abordar o tema da pluralidade de visões e vivências existentes no Rio de Janeiro. Busquei investigar através destes diferentes olhares sobre a cidade o que apontavam sobre desejos para o espaço urbano carioca e através de quais características cada um procurava representar o espaço do Rio de Janeiro.

Primeiramente, tratei do pensamento que buscou construir a imagem-marca da cidade para divulga-la internacionalmente. Uma imagem que, ao criar uma síntese do que seria o Rio de Janeiro, acabaria por excluir diferentes formas de habitar a cidade e de "ser" carioca. Ao abordá-la no capítulo 3, propus investigar elementos que pretenderam construí-la ao longo dos anos em questão. Neste contexto, tracei três exemplos de ações desenvolvidas pelas gestões municipal e estadual do período, os quais pareciam contribuir para "resgatar" o imaginário da Cidade Maravilhosa após anos de crise: trouxe exemplificações construídas em materiais publicitários, abordei a busca pela chancela de órgãos internacionais como a UNESCO, e apontei também transformações do espaço materializadas em intervenções urbanas. Os três exemplos, a meu ver, são representativos do tipo de pensamento que pautaria as cidades contemporâneas pretendidas como parte da "rede global de cidades".

Segundo a lógica empregada, o Rio de Janeiro estaria "no caminho" para tornar-se uma cidade "bem-sucedida". Todos os requisitos necessários para promover o patriotismo cívico dos moradores e a promoção da cidade internacionalmente estavam sendo atendidos. Divulgava-se a cidade como um cenário de beleza 
exuberante, um centro urbano que investia em projetos sustentáveis, que seria tecnológico e "atual". A "modernização" da cidade passava por ter obras de famosos arquitetos, novas atrações e novos cenários de cartões postais. As intervenções urbanas estariam, segundo o discurso, finalmente devolvendo os espaços públicos ao carioca, tal como era abordado sobre a Praça Mauá e a Orla Luiz Paulo Conde. Para além de tais aspectos, o Rio de Janeiro passava também a ter todo o seu potencial chancelado por respeitados títulos: a natureza da cidade e a sua "paisagem cultural" tornavam-se Patrimônio Mundial da Humanidade pela UNESCO. A representação que se desenhava também através de campanhas publicitárias - as quais estariam alinhadas às mais recentes técnicas de marketing, tal como o Branding - buscavam construir no habitante o orgulho de ser carioca.

A lógica utilizada na construção da representação pretendida para a cidade era própria ao autoritarismo técnico, característico desde as cidades industriais, a qual procura definir o futuro da cidade e, importante destacar, o que se entende pelo termo "futuro". Neste cenário, o simplismo de pensamento sobre o espaço urbano acabaria por não solucionar - ou mesmo intensificar - os problemas sociais da cidade (SANTOS, 1988). O que se viu, neste contexto, foi a tentativa de "resolver problemas" que não condiziam com a imagem internacional da cidade: o que era entendido como "pobreza", precisaria ser controlado ou escondido - como apontado através de exemplos no capítulo 3, com as UPPs e remoções.

Como alternativa para reflexão sobre o futuro do espaço urbano do Rio de Janeiro, apoiei-me em Lefebvre, não só no que tange ao direito dos moradores de habitarem plenamente suas cidades e de transformá-las conforme seus desejos e necessidades (2006b), mas também a partir do que propõe em seu livro “A produção do espaço" (2006a). As colocações de que o espaço urbano nunca será passivo às representações impostas e que, para pensar sobre seu futuro e sua essência é necessário atentar-se para a multiplicidade existente nas práticas do espaço, foram questões fundadoras para a pesquisa.

Neste contexto, apontei representações sobre o cotidiano da Favela Nova Holanda, construídas por três fotógrafos moradores da Maré, como contraponto à representação hegemônica que se buscava consolidar para a "Cidade Maravilhosa dos megaeventos". Através da importância da representação do espaço vivido para 
a reflexão da cidade e, ainda, a partir da urgência de considerar a autorrepresentação construída por habitantes de áreas excluídas da cidade, tal como as favelas, propus uma forma alternativa para olharmos o Rio de Janeiro e pensarmos sobre quais questões são consideradas pelos moradores como importantes para o espaço urbano. Através da investigação sobre como as pessoas fazem, sentem e percebem a cidade, procurei investigar o que poderia ser o "algo diferente" descrito por Lefebvre (apud HARVEY, 2014), que apontaria para possíveis desdobramentos de novos espaços.

As fotografias de Bira Carvalho, Elisângela Leite e Rosilene Miliotti, trabalhadas aqui, certamente são três visões dentro de muitas outras que constroem representações tão distintas do espaço urbano do Rio de Janeiro. A própria fotografia já denota, em si, o caráter de ser "traço de um real", como visto a partir de Philippe Dubois (2015). Sem pretender tratar tais imagens como verdades únicas ou absolutas sobre a cidade, trouxe o olhar dos fotógrafos como ferramenta para discutir a cidade a partir da visão de quem o habita. E, importante acrescentar ainda, de habitantes que vivem em espaços do Rio de Janeiro que propõem/constroem sua própria organização espacial. Acredito que a discussão colocada aqui a partir de tais parâmetros - abordar a visão do olhar do morador e falar sobre a cidade a partir de uma favela - confere maior potencialidade à investigação proposta. $\mathrm{O}$ ato fotográfico, neste contexto, é entendido não apenas como ferramenta de denúncia e desconstrução de estigmas, mas também como fonte de reflexão sobre o vir-a-ser da cidade.

A partir de tais questões, procurei pontuar representações construídas pelos três fotógrafos ao longo do capítulo 4. As imagens registram intervenções temporárias para o lazer e a confraternização, falam sobre unidades comerciais que se transformam a todo o tempo, além de abordar também a postura e atitude dos moradores frente a intervenções do Estado (sejam elas urbanas ou de segurança). Entre diferentes tópicos sobre o cotidiano, apontam para códigos locais, mostram um espaço que é entendido como pertencente ao coletivo, mas onde também, simultaneamente, as individualidades são reivindicadas em um constante jogo de negociação pelo uso do espaço. Abordam questões sobre resistência e luta por um local que esteja de acordo com as necessidades de seus moradores. Ao reunir o 
conteúdo das entrevistas e das imagens, foi possível organizar os pontos que se destacaram em quatro "macro temas", os quais apontariam para características sobre o espaço, apontadas pelos fotógrafos como representativas da Nova Holanda.

Na primeira "categoria" apresentada no capítulo 4, intitulada "espaço próprio", falou-se sobre os moradores ter o espaço comum "como quintal", em outras palavras, sobre "sentir-se em casa" na rua e utiliza-la para apropriações referentes a interesses particulares. Tratou-se aqui de imagens que mostravam intervenções físicas como piscinas de plástico em esquinas, tendas de eventos no centro de vias, televisões na rua para que amigos se reunissem em ocasiões especiais - tal como em jogos de futebol -, mesas de ping-pong e de jogos de carta ou pistas de skate. Imagens que falam também sobre o enfeitar do espaço, mostram procissões religiosas ou grafites nas paredes. Através de diferentes formas, apontam para uma relação de proximidade do morador com o espaço comum.

Ainda nesta categoria, destacou-se também a finalidade através da qual o espaço é muitas vezes apropriado: apesar de possuir uso diverso, muitas das ocasiões registradas abordam apropriações com finalidade de confraternização. Neste contexto, cabe frisar, diversas das imagens mostram o uso da rua para o "estar", frente ao "circular" (finalidade através da qual a rua seria geralmente conhecida). A rua - em particular as de pequeno porte - são entendidas como lugar de encontro. Através de diferentes formas, as imagens e os relatos apontam para uma relação de "proximidade" do morador com o espaço comum. A questão sobre ter a rua "como quintal" reflete tal ideia, além de falar também sobre a pluralidade de usos feitos no espaço.

A segunda "categoria", denominada aqui como "espaço compartilhado", fala sobre a questão do compartilhar o espaço comum. A pluralidade de usos e o entendimento do espaço como "seu" - apontadas no item anterior - resultam em um espaço que se constrói através de "negociações" diárias. O compartilhar do espaço aborda a questão da interação e troca entre pessoas pertencentes a grupos que seriam consideravelmente distintos entre si (a diversidade local abordada aqui, refere-se não só às vivências realizadas no espaço, mas também às pessoas que o frequentam). Tais questões, resultariam, em diferentes momentos, em redes de "confiança", "crédito" e criando "laços" entre vizinhos. Em resumo, como questão 
principal sobre esta categoria, coloca-se a criação de padrões de composição do espaço que se sobrepõem por causa da pluralidade local e das consequentes “práticas de negociação” (MELLO et al., 1985) que surgirão em tal contexto.

Já a terceira categoria, "espaço dinâmico", refere-se a colocações sobre a Nova Holanda ser um local que se transforma em pequenos espaços de tempo e através de diferentes dimensões do espaço (seja através da esfera física, social ou mesmo simbólica). Ao longo das entrevistas foram usados termos para se referir à favela tais como "viva", "um fervo", "ligada no 220V", um espaço que "não para". O entendimento sobre a intensidade e mistura de características influenciariam sua essência "orgânica", de um lugar que se transforma não apenas ao longo dos "turnos" do dia e das épocas do ano, mas também através de intervenções físicas permanentes. Entre os motivadores para esta característica, falou-se sobre a importância que os moradores dariam para a vida na rua, além das trocas e encontros que acontecem em seu espaço (questões tratadas nos itens anterior). Especificamente sobre as transformações de caráter permanente - as quais referiam-se a recorrentes mudanças no espaço construído - falou-se sobre sua motivação ser ligada a fins financeiros. Este fato influenciaria em mudanças recorrentes em espaços comerciais ou unidades residenciais (seja para aluguel de cômodos ou expansão da área construída para agregar o crescimento da família).

A última "categoria", denominada como "espaço de fé e resistência", aborda como as palavras "fé", "luta" e "resistência" - citadas em diferentes momentos influenciariam na conformação do espaço e na vivência local. Apontou-se que tais questões interfeririam diretamente, em certos momentos, sobre a forma de usar e de "fazer" o espaço. Neste contexto, enquanto a "fé" estaria mais ligada à demonstração de aspectos religiosos no espaço comum (fosse através de intervenções físicas ou em procissões e eventos), a questão relativa à "resistência" apontaria para a postura dos moradores em relação à construção do cotidiano ou da busca por manter um dia-a-dia "normal”, apesar das adversidades.

As práticas realizadas nas ruas parecem revelar a essência da Nova Holanda, um espaço recriado constantemente através do compartilhar entre os diversos usos e pessoas distintas. Alinhado ao pensamento de Michel de Certeau, "tal como o ato de falar cria a língua, os fazeres cotidianos efetuam o espaço" (apud MELLO \& 
VOGEL, 2005), os fotógrafos apontam para a importância dos "fazeres cotidianos" dos moradores na produção contínua do espaço da Maré, sendo os encontros no espaço comum fundamentais para tanto: tal como o ato de falar cria a língua, a vida pulsante e as trocas nas ruas da Nova Holanda parecem construir a forma do espaço.

Entre imagens que falam sobre apropriação, confraternização, luta e fé, os profissionais destacam características que consideram representativas sobre seu espaço. As representações dos fotógrafos mostram um local construído pelas "pessoas reais da escala da rua" - elementos importantes para pensar o espaço, como apontava a Internacional Situacionista (JACQUES, 2003). Falam sobre um local em constante transformação, com moradores que reivindicam um espaço de encontros, que garanta o direito ao lazer, ao lúdico, à surpresa, à Festa.

A partir do olhar do cotidiano da Nova Holanda, busquei questionar a maneira como o Rio de Janeiro foi construído - e representado - no período aqui trabalhado. Da mesma forma, pontuei questões sobre olharmos a cidade a partir das favelas, entendendo o seu espaço a partir de suas potencialidades. Busquei colocar o questionamento em relação à visão hegemônica sobre "desordem", propondo um entendimento de sua constituição como uma outra ordem (SANTOS, 2009).

Pensar sobre o futuro das cidades passa por conhece-las em sua multidimensionalidade e através de seus diferentes espaços. E a cidade, palco de luta pelo desejo do vir-a-ser, torna-se fonte para investigar-se o "desejado" frente ao “possível”. Como aponta Carlos Nelson Ferreira dos Santos (1988),

Centros urbanos são, em si mesmo, fontes abertas e inesgotáveis de ideias que saltam de seu simbolismo escancarados e são todos os dias decodificados, absorvidas e reelaboradas, nas ruas, nas praças, nos meios de transporte, nos locais de trabalho, em todo canto. (SANTOS, 1988, p.46)

Que a rua e seus múltiplos usos e vivências possam servir de fundamento para a reflexão real sobre a cidade. 


\section{Referências bibliográficas}

ABREU, Mauricio. Evolução Urbana do Rio de janeiro. Rio de Janeiro: IPLANRIO, 1997.

ARANTES, O.; VAINER, C.; MARICATO, E. A cidade do pensamento único: desmanchando consensos. Rio de Janeiro: Editora Vozes, 2000.

BARANDIER, Henrique. Projeto urbano no Rio de Janeiro e as propostas para a área central nos anos 1990. In: SILVA, Rachel Coutinho Marques da. A cidade pelo Avesso: desafios do urbanismo. Rio de Janeiro: Viana \& Mosley, PROURB, 2006.

BARBER, Mariah; MACKAY, Rhona. A História Pouco Conhecida da Pequena África na Zona Portuária do Rio de Janeiro. Trad. MACHADO, Halina. 2016. Disponível em: <http://rioonwatch.org.br/?p=20172>. Acesso em: abril 2017.

BARBOSA, Jorge Luiz. A arte de representar como reconhecimento do mundo: o espaço geográfico, o cinema e o imaginário social. In: Revista GEOgraphia. Rio de Janeiro: ano II, n. 3, 2000.

Paisagens da natureza, lugares da sociedade. A construção imaginária do Rio de Janeiro como cidade maravilhosa. In: SILVA, Jailson de Souza. BARBOSA, Jorge. FAUSTINI, Marcus Vinicius. O novo carioca. Rio de Janeiro: Mórula Editorial, 2012a, p. 23-41

Cidade e território. Desafios da reinvenção da política do espaço público. In: SILVA, Jailson de Souza. BARBOSA, Jorge. FAUSTINI, Marcus Vinicius. O novo carioca. Rio de Janeiro: Mórula Editorial, 2012b, p. 69-73

\& SILVA, Jaílson. As favelas como territórios de reinvenção da cidade. In: Cadernos do Desenvolvimento Fluminense. Rio de Janeiro, n.1, 2013.

BARTHES, Roland. A câmara clara: nota sobre a fotografia. Rio de Janeiro: Nova Fronteira, 2015.

BELTING, Hans. Antropologia da Imagem: para uma ciência da imagem. Lisboa: KKYM+EAUM, 2014.

BENEVOLO, Leonardo. História da cidade. São Paulo: Perspectiva, 2001

BRUM, Mario. Ordem, empreendedorismo e formalização: as novas funções para a pobreza urbana no Rio de Janeiro Global. In: Brasiliana Journal for Brazilian Studies, vol. 4, n.2, 2016.

BURGOS, Marcelo. Favela e luta pela cidade: esboço de um argumento. In: O que é favela, afinal? Rio de Janeiro: Observatório de Favelas, 2009.

CARLOS, Ana Fani Alessandri. A cidade. São Paulo: Contexto, 2005.

. Espaço-tempo na metrópole. São Paulo: Contexto, 2001 
Da Organização à "produção do espaço no movimento do pensamento geográfico. In: CARLOS; SOUZA; SPOSITO (Org.). A produção do espaço Urbano. São Paulo: Contexto, 2011, p.53-73.

CANDIDA, Simone. Cais do Valongo pode se tornar Patrimônio da Humanidade. Jornal O Globo, Rio de Janeiro, 23 out 2016. Disponível em: https://oglobo.globo.com/rio/cais-do-valongo-pode-se-tornar-patrimonioda-humanidade-20340002. Acesso em: abril, 2017.

CALVINO, Italo. As cidades invisíveis. São Paulo: Companhia das Letras, 1990.

CARMINATTI, Thiago Zanotti. Imagens da favela, imagens pela favela: etnografando representações e apresentações fotográficas em favelas cariocas. In: GONÇALVES, Marco Antonio; HEAD, Scott (orgs). Devires Imagéticos. A etnografia, o outro e suas imagens. Rio de Janeiro: 7letras, 2009, p.68-90.

Imagens da Favela, Imagens pela Favela: representações de si e do outro nas imagens do povo. Dissertação de mestrado em Sociologia e Antropologia na PPGSA/UFRJ, 2008.

CASTELLS, Manuel; BORJA, Jordi. As Cidades como Atores Políticos. IN: Novos Estudos. CEBRAP, n45, jul. 1996 pp.152-166.

CAVALCANTI, Mariana. À espera, em ruínas: Urbanismo, estética e política no Rio de Janeiro da 'PACificação'. In: Dilemas: Revista de Estudos de Conflito e Controle Social. Rio de Janeiro: UFRJ - Vol 6 - n2, 2013, p.191-228.

CEASM. Quem somos? Quantos somos? 0 que fazemos? A Maré em dados: Censo 2000. Rio de Janeiro, 2000.

CHIAVARI, Maria Pace. Rio de janeiro: de Paraíso a Narciso. In: MACHADO, D. B. P.; VASCONCELLOS, Eduardo M. Cidade e Imaginação. Rio de Janeiro: UFRJ, FAU, PROURB, 1996, p. 55-62.

CHOAY, Françoise. O urbanismo. São Paulo: Editora Perspetiva, 1965.

CORBUSIER. Urbanismo. São Paulo, Martins Fontes, 2000.

COUTO, Maria Isabel. UPP e UPP Social: narrativas sobre integração na cidade. Tese de doutoramento em Sociologia no IESP/UERJ. Rio de Janeiro, 2016.

DEBORD, Guy. A sociedade do espetáculo. Rio de Janeiro: Contraponto, 2015.

DELGADO, Manuel. 0 espaço público como representação. Espaço urbano e espaço social em Henri Lefebvre. Trad. Bismarck; Piteira. Revista Punkto. Porto, 2017. http://www.revistapunkto.com/2014/01/oespaco-publico-como-representacao_9694.html

DINIZ, Nelson. Porto maravilha: antecedentes e perspectivas da revitalização da região portuária do Rio de Janeiro. Rio de Janeiro: Letra Capital, 2014. 
DUARTE, Cristóvão. A "reinvenção" da cidade a partir dos espaços populares. In: $O$ que é favela, afinal? Rio de Janeiro: Observatório de Favelas, 2009.

DUBOIS, Philippe. $\mathbf{O}$ ato fotográfico e outros ensaios. Campinas: Papirus, 2015.

EL-YOUSSEF, Nour. Maior Cemitério de Escravos das Américas Fechará Devido ao Abandono pelas Autoridades do Rio. Trad. Marina Hennies. 2017. Disponível em: <http://rioonwatch.org.br/?p=25052>. Acesso em: abril 2017.

FAULHABER, Lucas; AZEVEDO, Lena. SMH 2016: Remoções no Rio de Janeiro Olímpico. Rio de Janeiro: Mórula Editorial, 2015.

FERREIRA, Álvaro. A produção do espaço: entre dominação e apropriação. Um olhar sobre os movimentos sociais. IX coloquio internacionald e Geocrítica: Los problema del mundo actual. Socluciones y alternativas desde la geografia y las ciencias sociales, 2007.

FERREIRA, Karine. E o teleférico da Providência? Agência de Notícias das Favelas. Rio de Janeiro, 10 jan. 2017. Disponível em: <http://www.anf.org.br/e-o-teleferico-da-providencia/>. Acesso em: abril 2017.

FOSTER, Hal. O Complexo arte-arquitetura. São Paulo: Cosac Naify, 2015.

Galiza, Helena Rosa dos Santos. Reabilitação de áreas centrais sem gentrificação. Tese de doutoramento em Arquitetura e Urbanismo no PROURB/UFRJ. Rio de Janeiro, 2015.

GANDRA, Alana. Moradores denunciam que teleférico da Providência virou "telepombo". Agência Brasil. Rio de Janeiro, 13 março 2014. Disponível em: <http://agenciabrasil.ebc.com.br/geral/noticia/201403/teleferico-da-providencia-esta-virando-um-telepombo-denunciammoradores>. Acesso em: abril 2017.

GAMA, Fabiene. Fotodocumentação e participação política: um estudo comparativo entre o Brasil e o Bangladesh. Tese de doutoramento em Antropologia no PPGSA/UFRJ e EHESS, 2012.

GONÇALVES, Rafael Soares. Favelas do Rio de Janeiro: história e direito. Rio de Janeiro: Ed. Puc-Rio, 2013.

;) SIMÕES, Soraya Silveira; MAGALHÃES, Alex Ferreira. Apresentação: Grandes eventos, múltiplos impactos, grandes mobilizações. In: Revista O Social em Questão. Rio de Janeiro, ano XV, n.28, 2012, pp.9-20.

GURAN, Milton. Fotografia e pesquisa antropológica. In: Caderno de textos: antropologia visual. Rio de janeiro: Museu do Índio, 1987.

. Fotografar para descobrir, fotografar para contar. In: Cadernos de antropologia e imagem. Rio de Janeiro: Eduerj, 2000, p.155-165. 
HABERMAS, J. Arquitetura moderna e pós-moderna; Modernidade: um projeto inacabado. In: ARANTES, Otília Beatriz Fiori \& Paulo Eduardo. Um ponto cego no projeto estético de Jürgen Habermas: arquitetura e dimensão estética depois das vanguardas. São Paulo, Brasiliense, 1987.

HALL, Peter. Cidades do amanhã. São Paulo: Perspectiva.1988.

HAROUEL, Jean-Louis. História do urbanismo. São Paulo: Papirus, 2004.

HARVEY, David. A liberdade da cidade. In: Cidades Rebeldes: Passe Livre e as manifestações que tomaram as ruas do Brasil. São Paulo (SP): Boitempo: Carta Maior, 2013a. p. 27 a 34.

Condição pós-moderna. SP, Edições Loyola, 1993.

. O direito à cidade. In: Revista Piauí, São Paulo, edição 82, Editora Estadão, 2013b. <http://revistapiaui.estadao.com.br/edicao-82/tribunalivre-da-luta-de-classes/o-direito-a-cidade>.

. Cidades Rebeldes: do direito à cidade à revolução urbana. São Paulo: Martins, 2014.

. Espaços de esperança. São Paulo: Loyola, 2006

. 2015. O espaço como palavra-chave. Trad. GIANELLA; HAESBAERT; NUNES. In: Revista Em Pauta: teoria social e realidade contemporânea, n. 35, (original: Space as a keyword. In: Castree, N. e Gregory, D. (org.) David Harvey: a critical reader. Malden e Oxford: Blackwell, 2006), 2015.

HUGUENIN, J.P.O.; ANDRADE, L.S. Favelas cariocas: Pelo seu reconhecimento como paisagem cultural do Rio de Janeiro, in: Anais III Colóquio Ibero-Americano, Belo Horizonte, 2016.

IMAGENS DO POVO. Imagens do Povo. Rio de Janeiro: Nau Editora, $2011 . \quad$ Disponível em: $<$ http://issuu.com/imagensdopovo/docs/livroip/33?e=0>. Acesso em: nov 2015.

IMPRENSA OFICIAL DO ESTADO DO RIO DE JANEIRO. Beleza do Rio encanta moradores e visitantes. Rio de Janeiro, 19 julho 2011. Disponível em:

$<$ https://www.ioerj.com.br/portal/modules/news/article.php?storyid=2 56>. Acesso em: abril 2017.

IPHAN. Dossiê Rio de Janeiro - paisagens cariocas entre a montanha e o mar. Rio de Janeiro, 2009. Disponível em: <http://portal.iphan.gov.br/uploads/ckfinder/arquivos/Dossi\%C3\%AA\%20p ortugu\%C3\%AAs\%2028\%20mar\%C3\%A70\%202011\%20RJ.pdf_1316.pdf>. Acesso em: abril. 2017.

. Cais do Valongo é candidato a Patrimônio da Humanidade. Disponível em: <http://portal.iphan.gov.br/noticias/detalhes/3489/cais- 
do-valongo-e-candidato-a-patrimonio-da-humanidade>. Acesso em: abril 2017.

JACOBS, Jane. Morte e vida das grandes cidades. São Paulo, Martins Fontes, 2000.

JACQUES, Paola Berenstein. Apologia da deriva. Rio de Janeiro: Casa da Palavra, 2003.

. Espetacularização urbana contemporânea. In: Cadernos PPG-AU FAUFBA, Territórios urbanos e políticas culturais, ano II, Salvador 2004 n especial, p. 23-30.

. Errâncias Urbanas - a arte de andar pelas cidades. In: ARQTEXTO 7. Rio Grande do Sul, n.7, p. 16-25, $1^{\circ}$ semestre de 2005. Disponível online.

Microressistências urbanas: por um urbanismo incorporado. In: ROSA, Marcos L (org). Microplanejamento Práticas urbanas criativas. São Paulo, Editora de Cultura, 2011a.

Estética da ginga: a arquitetura das favelas através da obra de Hélio Oiticica. 4. ed. Rio de Janeiro: Casa da Palavra, 2011b.

. VARELLA, Drauzio; BERTAZZO, Ivaldo. Maré, vida na favela. Rio de Janeiro: Casa da Palavra, 2002.

KAMITA, João Masao. A nova Praça Mauá. O Rio do espetáculo. Arquitextos, São Paulo, ano 16, n. 187.02, Vitruvius, dez. 2015

Disponível em:

<http://www.vitruvius.com.br/revistas/read/arquitextos/16.187/5885>.

KAVARATZIS, Michalis. From city marketing to city branding: Towards a theoretical framework for developing city Brands. In: Place Branding. Henry Stewart Publications, Vol. 1, 58-73, 2004.

KOOLHAAS, Rem. A cidade genérica. In: Três textos sobre a cidade. Barcelona: Rubi, 2010.

KOSSOY, Boris. Realidade e Ficções na Trama fotográfica. São Paulo: Ateliê Editora, 2016.

LEEDS, Anthony; LEEDS, Elizabeth. A sociologia do Brasil urbano. Rio de Janeiro: Zahar, 1977.

LEFEBVRE, Henri. Posição: contra os tecnocratas. São Paulo: Editora Documento, 1969. 1991.

A vida cotidiana no mundo moderno. São Paulo: Editora Ática,

A revolução urbana. Belo Horizonte: Editora Humanitas, 2004.

A produção do espaço. Trad. Grupo as (im)possibilidades do urbano na metrópole contemporânea" do núcleo de geografia Urbana da UFMG (do original: La production de l'espace. 4 ed. Paris: Editions Antrophos, 2000), 2006a.

. O direito à cidade. São Paulo: Centauro, 2006b. 
LEITE, Márcia da Silva Pereira. Violência, risco e sociabilidade nas margens da cidade: percepções e formas de ação de moradores de favelas cariocas. IN: SILVA, Luiz Antonio Machado da (org). Vida sob cerco: violência e rotina nas favelas do Rio de Janeiro. Rio de Janeiro: Nova Fronteira, 2008.

. Da "metáfora da guerra" ao projeto de "PACificação": favelas e políticas de segurança pública no Rio de Janeiro. IN: Revista Brasileira de Segurança Pública. São Paulo, v.6, n.2, ago/set 2012, pp374-389.

LIMA, Ludmilla de. Quinze empreendimentos prometem levar futuro para a Zona Portuária, uma das mais antigas do Rio. Jornal O Globo, Rio de Janeiro, 11 out. 2014. Disponível em: https://oglobo.globo.com/rio/quinze-empreendimentos-prometem-levarfuturo-para-zona-portuaria-uma-das-mais-antigas-do-rio-14218691.

Acesso em: abril, 2017.

MACHADO DA SILVA, Luiz Antonio (1997). Criminalidade Violenta e Ordem Pública: nota metodológica. Trabalho apresentado no VIII Congresso da Sociedade Brasileira de Sociologia.

A continuidade do "problema favela". IN: OLIVEIRA, Lucia Lippi (Org.). Cidade: história e desafios. Rio de Janeiro: Fundação Getúlio Vargas, 2002.

MARICATO, Erminia. Brasil, Cidades: alternativas para a crise urbana. Rio de Janeiro: Editora Vozes, 2001.

MASCARENHAS, G. A produção da cidade olímpica e os sinais da crise do modelo globalitário. Geousp - Espaço e Tempo (Online), v. 20, n. 1, p. 52-68, mês. 2016.

MARINHO, Rafaela. Tishman Speyer contrata Norman Foster para projeto no Rio. Revista Exame, São Paulo, 5 de julho 2013. Disponível em: <http://exame.abril.com.br/negocios/tishman-speyer-contrata-normanfoster-para-projeto-no-rio/>. Acesso em: abril, 2017.

MARTINS. José de Souza. Sociologia da fotografia e da imagem. São Paulo: Contexto, 2016.

MELLO, Marco A.; VOGEL, Arno. Lições da rua: o que um racionalista pode aprender no catumbi. In: LIMA, Roberto Kant; MELLO, Marco A.; FREIRE, Letícia de Luna. Pensando o Rio. Rio de Janeiro: Editora Intertexto, 2005.

Sistema Construído e Memória Social: uma Arqueologia Urbana? In: Revista de Arqueologia. Belém: Museu Paraense Emílio Goeldi, v.2, n.2., jul/dez. 1984, p. 46-50.

. et al. Quando a rua vira casa. São Paulo. Projeto Arquitetos Associados, 1985.

MUNFORD, Lewis. A cultura das cidades. Belo Horizonte: Editora Itatiaia, 1961.

A cidade na história. São Paulo: Martins Fontes, 2004. 
MUSEU DO AMANHÃ. Amanhã vence Prêmio Internacional MIPIM.

Disponível em: <https://museudoamanha.org.br/pt-br/amanha-vencepremio-internacional-mipim>. Acesso em: abril 2017.

NEUMEIER, Marty. The brand gap. How to bridge the distance between business strategy and design. Califórnia: New Riders Publishing, 2003.

PARK, Robert Ezra. A cidade: sugestões para a investigação do comportamento humano no meio urbano. In: VELHO, Otávio Guilherme. O fenômeno urbano. Rio de Janeiro: Editora Guanabara, 1987.

PERLMAN, Janice. 0 mito da marginalidade. Rio de Janeiro: Paz e Terra, 1977.

PESAVENTO, Sandra Jatahi. O Imaginário da Cidade - Visões Literárias do Urbano - Paris, Rio de Janeiro, Porto Alegre. Porto Alegre: Ed. UFRGS, 1999.

PREFEITURA DO RIO DE JANEIRO. Plano Estratégico da Prefeitura do Rio de Janeiro: 2013-2016. 2013. Disponível em: $<$ http://www.conselhodacidade.com/v3/pdf/planejamento_estrategico_1316.pdf>. Acesso em: fev. 2017.

Disponível Rio - Gestão Alto Desempenho. $<\mathrm{http}: / / \mathrm{www}$.conselhodacidade.com/v3/pdf/RioGestaoAltoDesempenho.pd f>. Acesso em: fev. 2017

Rio de Janeiro - Patrimônio Mundial como Paisagem Cultural Urbana. Disponível em: <http://www.rio.rj.gov.br/web/irph/sitio-unesco>. Acesso em: abril 2017.

REDES DA MARÉ. Censo de empreendimento Maré Disponível em: http://redesdamare.org.br/wpcontent/uploads/2014/07/GuiaEmpreendedores_FINAL_18JUL.pdf. Acesso em: fev.2016

Guia de Ruas da Maré. 2013. Disponível em: <http://redesdamare.org.br/blog/publicacoes/a-mare-no-mapa/>. Acesso em: dez. 2015.

REZENDE, Constança. Dinheiro de obra em favela foi para Museu do Amanhã. Jornal O Estado de S. Paulo, São Paulo, 26 abril 2017. Disponível em: http://brasil.estadao.com.br/noticias/rio-de-janeiro,dinheiro-de-obraem-favela-foi-para-museu-do-amanha,70001752056. Acesso em: abril 2017.

RIBEIRO, Ana Clara Torres. Imaginação e Metrópole: as ofertas paradigmáticas do Rio de Janeiro e São Paulo. In: MACHADO, D. B. P.; VASCONCELLOS, Eduardo M. Cidade e Imaginação. Rio de Janeiro: UFRJ, FAU, PROURB, 1996, p. 55-62.

RIBEIRO, Paula, NÓBREGA, Edson Diniz; BELFORT, Marcelo Castro e Silva. Memória e identidade dos moradores de Nova Holanda. Rio de Janeiro: Redes da Maré, 2012.

RIBEIRO, Rafael Winter. Rio de Janeiro: paisagens cariocas entre a montanha e o mar | Rio de Janeiro: landscapes between the mountain 
and the sea / Rafael Winter Ribeiro; versão para o inglês/English translation: Maíra Mendes Galvão e Christine Eida Madureira. - Santos: Editora Brasileira de Arte e Cultura; Brasília: UNESCO, 2016.

ROLNIK, Raquel. O que é Cidade. São Paulo: Editora Brasiliense, 1988

Guerra dos lugares: a colonização da terra e da moradia na era das finanças. São Paulo: Boitempo, 2015.

ROSA, Marcos L. Microplanejamento: Práticas urbanas criativas. São Paulo, Editora de Cultura, 2011.

RYKWERT, Joseph. A imagem da cidade. São Paulo: Perspectiva, 2006. SANTOS, Carlos Nelson Ferreira do. Como e quando pode um arquiteto virar antropólogo? In: VELHO, Gilberto (org.). O desafio da cidade: novas perspectivas da antropologia brasileira. Rio de Janeiro: Campus, 1980.

. A cidade como um jogo de cartas. Niterói: EDUFF, 1988.

A desordem é só uma ordem que exige uma leitura mais atenta.

Revista de Administração Municipal - IBAM. Rio de Janeiro, ano 54, n. 271, p. 8-13, 2009. http://lam.ibam.org.br/revista_detalhe.asp?idr=827

SÁNCHEZ, Fernanda. Arquitetura e Urbanismo. Espaços de representação na cidade contemporânea. In: Revista Veredas. Centro Cultural Banco do Brasil. Ano 4, n.41, maio 1999.

A reinvenção das cidades na virada de século: agentes, estratégias e escalas de ação política. In: Revista Sociologia Política. Curitiba: 16, p. 31-49, 2001.

SILVA, Jaílson de Souza. A pluralidade de identidades no bairro Maré - Rio de Janeiro. In: Revista GEOgraphia, Niterói, v.5, p. 99-114, 2001.

. Um espaço em busca de seu lugar. As favelas para além dos esteriótipos. In: SILVA, Jailson de Souza. BARBOSA, Jorge. FAUSTINI, Marcus Vinicius. O novo carioca. Rio de Janeiro: Mórula Editorial, 2012, p. 43-61.

As Unidades de Polícia Pacificadoras e os novos desafios para as favelas cariocas. In: SILVA, Jailson de Souza. BARBOSA, Jorge. FAUSTINI, Marcus Vinicius. O novo carioca. Rio de Janeiro: Mórula Editorial, 2012, p.131-149

Bruxas e bruxos da cidade: personagens da revolução do cotidiano. Rio de Janeiro: Babilônia Cultural Editora, 2015.

SILVA, Maria Lais Pereira da. Favelas cariocas (1930-1964). Rio de Janeiro: Contraponto, 2005.

. Favela: É geral? É particular? É urbano?. In: O que é favela, afinal? Rio de Janeiro: Observatório de Favelas, 2009.

; PAULA, Tainá Reis de. A Iconografia das favelas cariocas, uma história de Omissão e recuperação, in: Anais do XI Encontro Nacional da ANPUR, Salvador, 2005

SOLA-MORALES, Ignasi de. Terrain Vague. In: Territórios. Barcelona: Editorial Gustavo Gili, 2002. 
SOUZA, Marcelo Lopes de. Mudar a cidade: uma introdução crítica ao planejamento e à gestão urbana. Rio de Janeiro: Bertrand Brasil, 2006.

. Espaço geográfico, espaço social, organização espacial e produção do espaço. In: _. Os conceitos fundamentais da pesquisa sócio-espacial. Rio de Janeiro: Bertrand Brasil, 2013, p.21-42.

SOUZA SILVA, Eliana. O movimento comunitário de Nova Holanda: na busca do encontro entre o político e o pedagógico. Dissertação de Mestrado apresentado ao Departamento de Educação da PUC-Rio, 1995. . Testemunhos da Maré. Rio de Janeiro: Aeroplano, 2012.

WEBER, Max. Conceito e categoria da cidade. In: VELHO, Otávio Guilherme. O fenômeno urbano. Rio de Janeiro: Editora Guanabara, 1987.

VALLADARES, Licia. A invenção da Favela - Do Mito de Origem a Favela.com. Rio de Janeiro: FGV, 2012.

WERNECK, Mariana. Porto Maravilha: agentes, coalizões de poder e neoliberalização. Dissertação de mestrado apresentado ao IPPUR/UFRJ, 2016.

ZALUAR, Alba; ALVITO, Marcos (orgs.). Um século de favela. Rio de Janeiro: FGV, 1998 